\title{
ESTUDOS DE DIREITO LATINO AMERICANO VOLUME XI
}

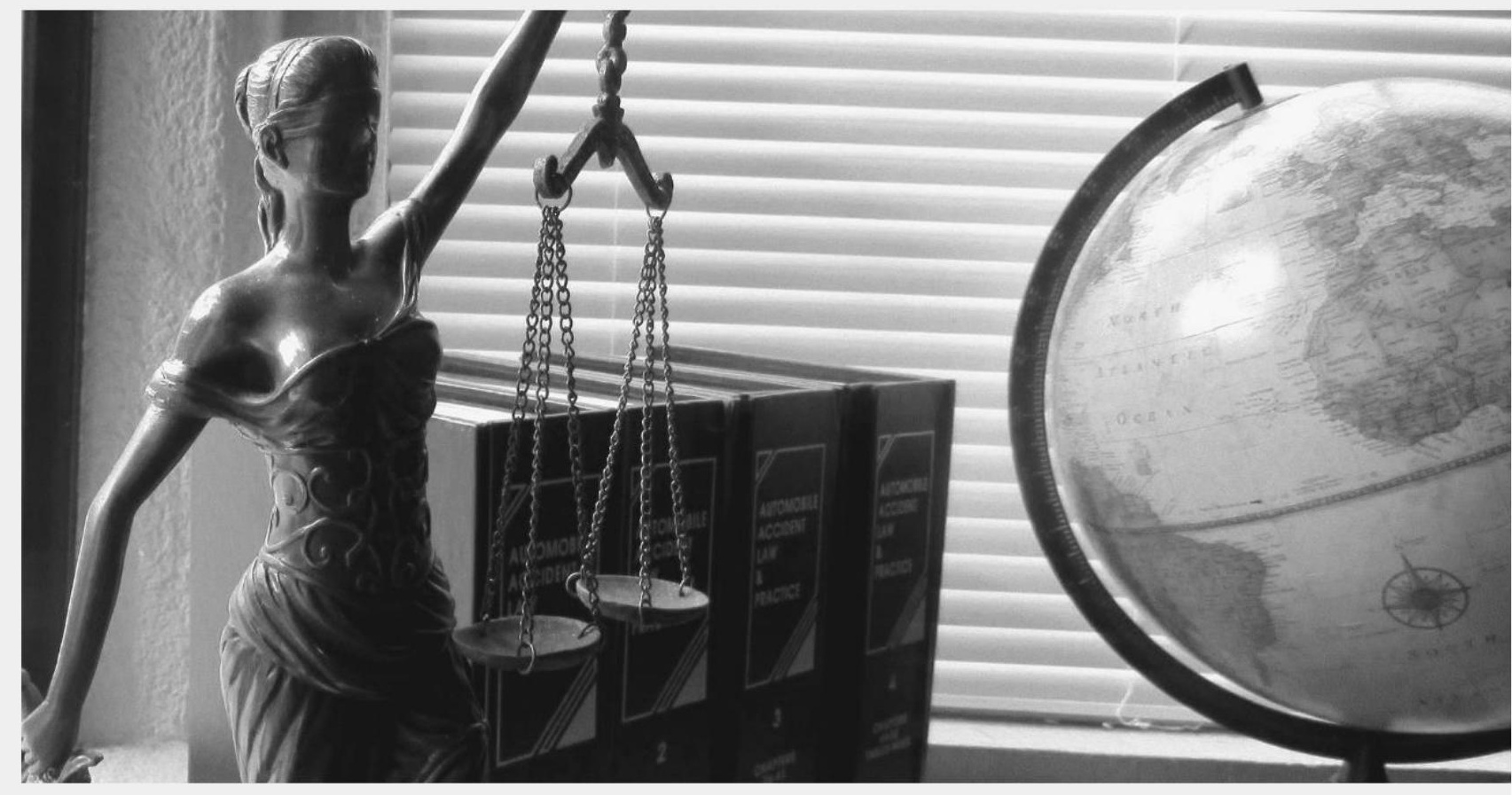

\section{ORGANIZAÇÃOO}




\section{ESTUDOS DE DIREITO \\ LATINO AMERICANO \\ VOLUME XI}

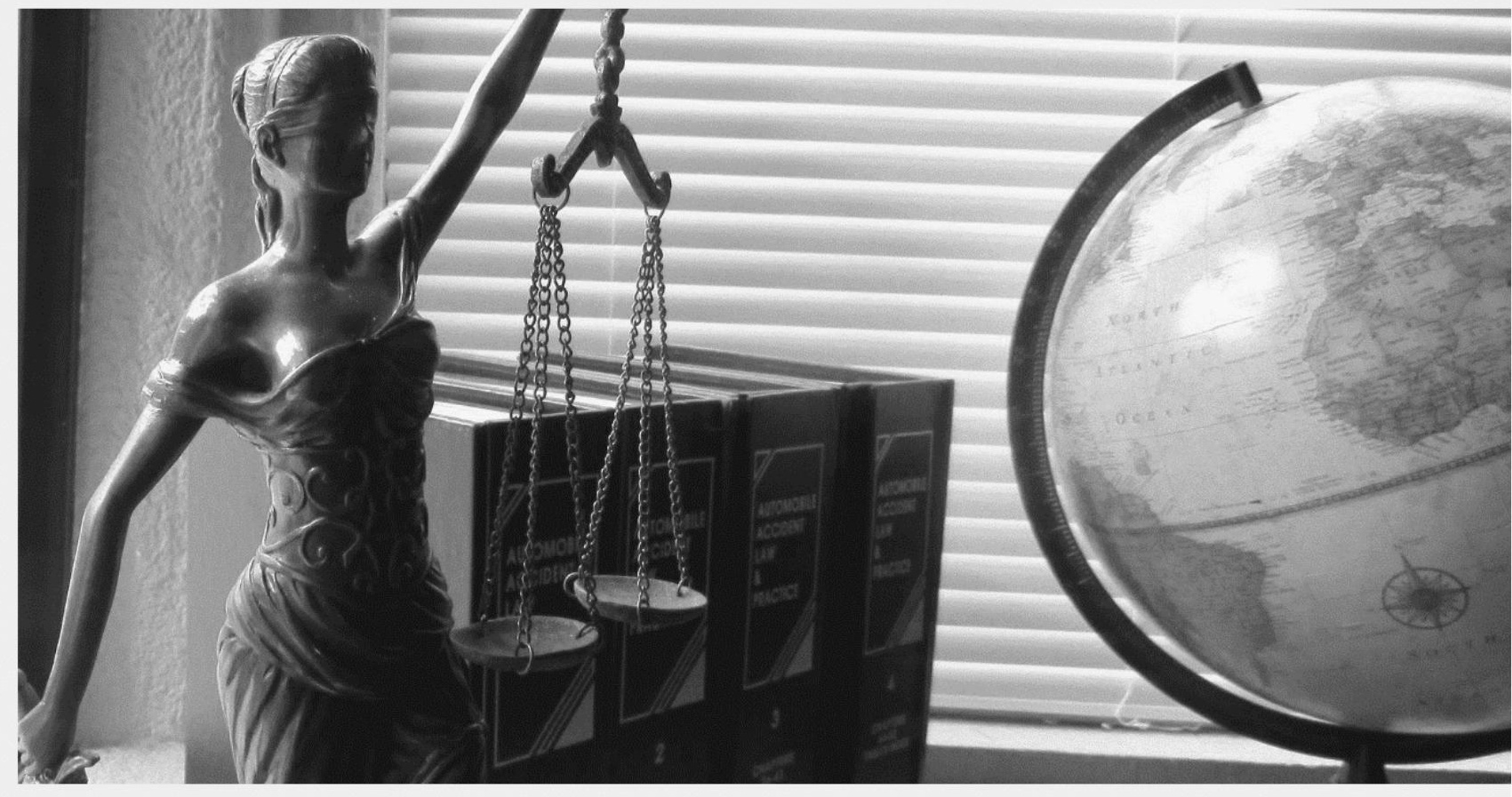

ORGANIZAÇÃO 
AMPLLA

2022 - Editora Amplla

Copyright (C) Editora Amplla

Editor Chefe: Leonardo Pereira Tavares

Design da Capa: Editora Amplla

Diagramação: Higor Costa de Brito

Estudos de Direito Latino Americano - Volume XI está licenciado sob CC BY 4.0.

(c) (i) Esta licença exige que as reutilizações deem crédito ao criador. Ele permite que os reutilizadores distribuam, remixem, adaptem e construam o material em qualquer meio ou formato, mesmo para fins comerciais.

O conteúdo da obra e seus dados em sua forma, correção e confiabilidade são de responsabilidade exclusiva dos autores, não representando a posição oficial da Editora Amplla. É permitido o download da obra e o compartilhamento desde que sejam atribuídos créditos aos autores. Todos os direitos para esta edição foram cedidos à Editora Amplla.

ISBN: 978-65-5381-003-7

DOI: 10.51859/amplla.edl1037-0

Editora Amplla

Campina Grande - PB - Brasil contato@ampllaeditora.com.br

www.ampllaeditora.com.br

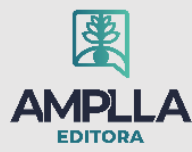




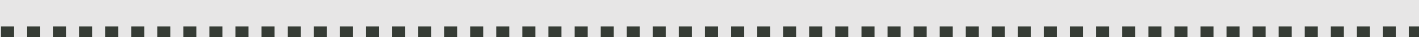

\section{CONSELHO EDITORIAL}

Andréa Cátia Leal Badaró - Universidade Tecnológica Federal do Paraná Andréia Monique Lermen - Universidade Federal do Rio Grande do Sul Antoniele Silvana de Melo Souza - Universidade Estadual do Ceará Bergson Rodrigo Siqueira de Melo - Universidade Estadual do Ceará Bruna Beatriz da Rocha - Instituto Federal do Sudeste de Minas Gerais Caio César Costa Santos - Universidade Federal de Sergipe Carina Alexandra Rondini - Universidade Estadual Paulista Carla Caroline Alves Carvalho - Universidade Federal de Campina Grande Carlos Augusto Trojaner - Prefeitura de Venâncio Aires Carolina Carbonell Demori - Universidade Federal de Pelotas Cícero Batista do Nascimento Filho - Universidade Federal do Ceará Clécio Danilo Dias da Silva - Universidade Federal do Rio Grande do Norte Daniela de Freitas Lima - Universidade Federal de Campina Grande Denise Barguil Nepomuceno - Universidade Federal de Minas Gerais Dylan Ávila Alves - Instituto Federal Goiano

Edson Lourenço da Silva - Instituto Federal de Educação, Ciência e Tecnologia do Piauí Elane da Silva Barbosa - Universidade Estadual do Ceará

Érica Rios de Carvalho - Universidade Católica do Salvador

Gilberto de Melo Junior - Instituto Federal do Pará

Higor Costa de Brito - Universidade Federal de Campina Grande

Italan Carneiro Bezerra - Instituto Federal da Paraíba

Ivo Batista Conde - Universidade Estadual do Ceará

Jaqueline Rocha Borges dos Santos - Universidade Federal Rural do Rio de Janeiro Jessica Wanderley Souza do Nascimento - Instituto de Especialização do Amazonas João Henriques de Sousa Júnior - Universidade Federal de Santa Catarina João Manoel Da Silva - Universidade Federal de Alagoas

João Vitor Andrade - Universidade de São Paulo

Joilson Silva de Sousa - Instituto Federal do Rio Grande do Norte José Cândido Rodrigues Neto - Universidade Estadual da Paraíba Jose Henrique de Lacerda Furtado - Instituto Federal do Rio de Janeiro Josenita Luiz da Silva - Faculdade Frassinetti do Recife Josiney Farias de Araújo - Universidade Federal do Pará Karina de Araújo Dias - SME/Prefeitura Municipal de Florianópolis Laíze Lantyer Luz - Universidade Católica do Salvador Lindon Johnson Pontes Portela - Universidade Federal do Oeste do Pará Lucas Capita Quarto - Universidade Federal do Oeste do Pará Lúcia Magnólia Albuquerque Soares de Camargo - Unifacisa Centro Universitário Luciana de Jesus Botelho Sodré dos Santos - Universidade Estadual do Maranhão Luís Paulo Souza e Souza - Universidade Federal do Amazonas Luiza Catarina Sobreira de Souza - Faculdade de Ciências Humanas do Sertão Central Manoel Mariano Neto da Silva - Universidade Federal de Campina Grande Marcelo Alves Pereira Eufrasio - Centro Universitário Unifacisa Marcelo Williams Oliveira de Souza - Universidade Federal do Pará Marcos Pereira dos Santos - Faculdade Rachel de Queiroz Marcus Vinicius Peralva Santos - Universidade Federal da Bahia Marina Magalhães de Morais - Universidade Federal de Campina Grande Nadja Maria Mourão - Universidade do Estado de Minas Gerais Natan Galves Santana - Universidade Paranaense Nathalia Bezerra da Silva Ferreira - Universidade do Estado do Rio Grande do Norte Neide Kazue Sakugawa Shinohara - Universidade Federal Rural de Pernambuco Neudson Johnson Martinho - Faculdade de Medicina da Universidade Federal de Mato Grosso Patrícia Appelt - Universidade Tecnológica Federal do Paraná Paulo Henrique Matos de Jesus - Universidade Federal do Maranhão 
Rafael Rodrigues Gomides - Faculdade de Quatro Marcos

Reângela Cíntia Rodrigues de Oliveira Lima - Universidade Federal do Ceará

Rebeca Freitas Ivanicska - Universidade Federal de Lavras

Renan Monteiro do Nascimento - Universidade de Brasília

Ricardo Leoni Gonçalves Bastos - Universidade Federal do Ceará

Rodrigo da Rosa Pereira - Universidade Federal do Rio Grande

Sabrynna Brito Oliveira - Universidade Federal de Minas Gerais

Samuel Miranda Mattos - Universidade Estadual do Ceará

Shirley Santos Nascimento - Universidade Estadual Do Sudoeste Da Bahia

Silvana Carloto Andres - Universidade Federal de Santa Maria

Silvio de Almeida Junior - Universidade de Franca

Tatiana Paschoalette Rodrigues Bachur - Universidade Estadual do Ceará

Telma Regina Stroparo - Universidade Estadual do Centro-Oeste

Thayla Amorim Santino - Universidade Federal do Rio Grande do Norte

Virgínia Maia de Araújo Oliveira - Instituto Federal da Paraíba

Virginia Tomaz Machado - Faculdade Santa Maria de Cajazeiras

Walmir Fernandes Pereira - Miami University of Science and Technology

Wanessa Dunga de Assis - Universidade Federal de Campina Grande

Wellington Alves Silva - Universidade Estadual de Roraima

Yáscara Maia Araújo de Brito - Universidade Federal de Campina Grande

Yasmin da Silva Santos - Fundação Oswaldo Cruz

Yuciara Barbosa Costa Ferreira - Universidade Federal de Campina Grande 


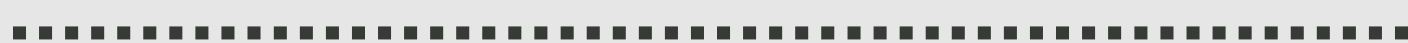

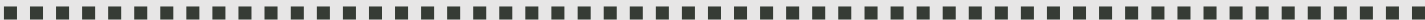
1

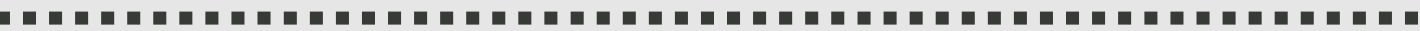

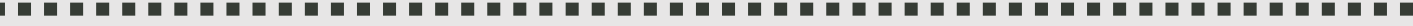

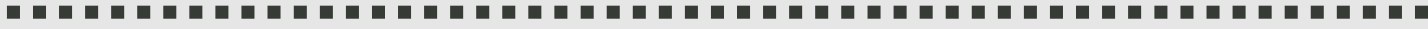

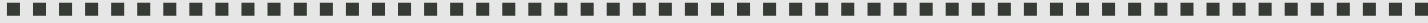
1ㅊ.

A3 AMPLLA

2022 - Editora Amplla

Copyright (C) Editora Amplla

Editor Chefe: Leonardo Pereira Tavares

Design da Capa: Editora Amplla

Diagramação: Higor Costa de Brito

Dados Internacionais de Catalogação na Publicação (CIP)

Estudos de Direito Latino Americano [livro eletrônico] / organização Ana Silvia Begalli, Gabriela Soares Balestero. -Campina Grande : Editora Amplla, 2022.

v. 11

Formato: PDF

ISBN : $978-65-5381-003-7$

1. Política. 2. Direito. 3. Constitucionalismo. I. Begalli, Ana Silvia. II. Balestero, Gabriela Soares. III. Título.

Sueli Costa - Bibliotecária - CRB-8/5213

(SC Assessoria Editorial, SP, Brasil)

Índices para catálogo sistemático:
1. Política
320
2. Direito

Editora Amplla

Campina Grande - PB - Brasil contato@ampllaeditora.com.br www.ampllaeditora.com.br

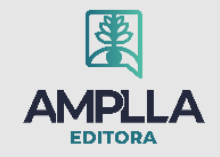


Com muita satisfação publicamos mais uma edição da coletânea "Estudos de Direito Latino Americano" em seu Volume XI. Trata-se de uma obra que visa reunir pesquisas sobre diversas temáticas jurídicas tanto do Brasil quanto da América Latina.

O primeiro capítulo intitulado "Políticas Públicas e Desigualdade Social nas cidades brasileiras: uma resenha crítica" foi fazer uma resenha crítica do artigo intitulado: Globalização e desafios urbanos: políticas públicas e desigualdade social nas cidades brasileiras, publicado na Revista Eure (Santiago), no ano de 2011. O artigo foi realizado através de uma pesquisa exploratória, assentada em uma revisão literária bibliométrica com procedimento quantiqualitativo e método histórico comparativo. endo como objetivo, compreender os diversos ciclos de crescimento econômico evitaram uma redistribuição mais equitativa da riqueza, agravando as desigualdades sociais e empobrecendo as populações urbanas brasileiras.

O segundo capítulo intitulado "O sequestro do ônibus 174: a generalização do Direito Penal do inimigo através da trajetória de Sandro Barbosa do Nascimento" é apresentada a história de Sandro Barbosa do Nascimento, que foi marcada pela ausência de suporte estatal, culminando em um sequestro do ônibus 174 no Rio de Janeiro, tentativa do agente de ser ouvido pelas autoridades. O estudo foi dividido em três etapas. Na primeira, é narrado o episódio criminoso envolvendo o transporte público. Em seguida, é exposta a história de Sandro desde sua infância, quando presenciou a morte de sua mãe a facadas até pouco antes do fatídico evento que o levou à morte pelas mãos de policiais com o objetivo de evidenciar a influência da negligência do Estado em sua formação. Por fim, é feita uma análise entre os trágicos acontecimentos ocasionados pela não efetivação das normas que dizem respeito ao direito à vida e segurança pública, bem como os requisitos básicos das garantias fundamentais, dentre eles saúde, alimentação e educação, com a tese descritiva de Günther Jakobs sobre o Direito Penal do Inimigo, que estabelece a marginalização e punição antecipada de indivíduos que insistem em violar os tipos penais, desligando-se do ser cidadão e regredindo ao chamado Estado Natural. 


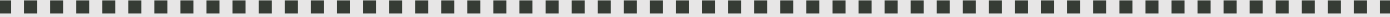

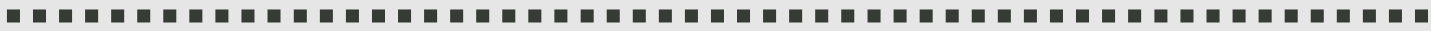

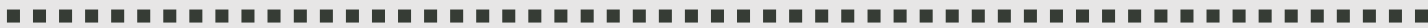

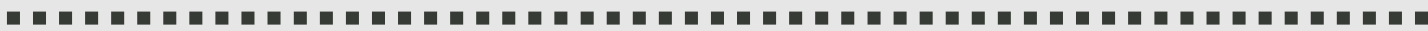

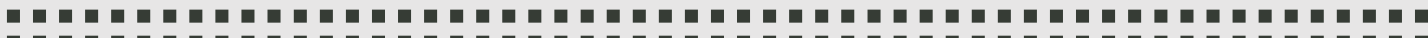

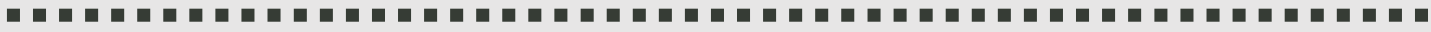

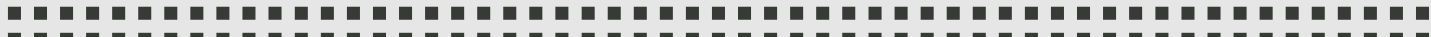

O terceiro capítulo intitulado "O licenciamento ambiental e o projeto de lei no 2159/2021 sob a perspectiva do desenvolvimento sustentável" é analisada a institucionalização de uma política de gestão ambiental é fenômeno recente no Brasil, que surgiu a partir de uma mudança global de conscientização ambiental durante a década de 1970, motivando a edição da Lei 6938/1981 através da qual, pela primeira vez em âmbito nacional, houve uma gestão integrada dos recursos naturais expressa por uma Política Nacional do Meio Ambiente (PNMA), que inovou ao prever instrumentos de gestão ambiental como o licenciamento ambiental. Trata-se do instrumento adotado para possibilitar a implementação, construção e operação de empreendimentos que tenham potencial poluidor, garantindo que a necessária proteção ambiental seja observada nesse processo. Esse processo, contudo, sofre diversas críticas quanto ao seu funcionamento, com diversas tentativas de alteração legislativa do processo atual, sendo que o objetivo do presente trabalho é analisar as alterações propostas pelo Projeto de Lei 2159/2021, Projeto de Lei 3.729/2004 e a introdução da Licença por Adesão e Compromisso a fim de responder o questionamento central levantado: se a adoção da LAC é um instrumento capaz de garantir maior eficiência ao processo de licenciamento ambiental ou se tal modificação no sistema pode colocar em risco a proteção ao meio ambiente e o objetivo de se promover o desenvolvimento sustentável previsto na Constituição da República Brasileira. Como objetivo específico, visa aprofundar a figura do licenciamento ambiental como instrumento do desenvolvimento sustentável e analisar as especificidades das alterações propostas.

O quarto capítulo intitulado "A eficiência da autofalência: análise custo-benefício de um instituto esquecido no ordenamento jurídico" tem como objetivo analisar a eficiência do instituto da autofalência (falência requerida pelo próprio devedor). 0 capítulo observa a Lei de Recuperação de Empresas e Falência (LREF) com o auxílio da Análise Econômica do Direito visando à análise dos custos de falência da autofalência e os benefícios trazidos ao optar pelo instituto, como a proteção ao patrimônio dos sócios e outras vantagens introduzidas em decorrência da alteração da Lei no 11.101/2005 pela Lei $n$ 14.112/2020. Ao final, conclui-se que a autofalência é um mecanismo viável que visa a diminuir os custos sociais de uma futura recuperação judicial infrutífera, diante da preocupação do Estado com a crise financeira e econômica de uma empresa. 


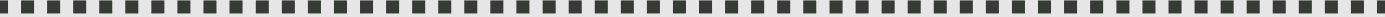

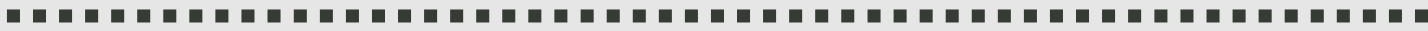

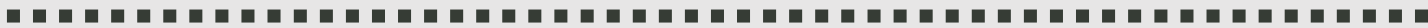

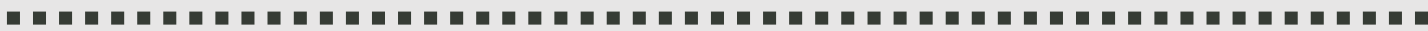

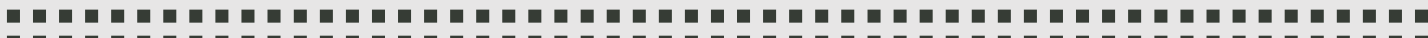

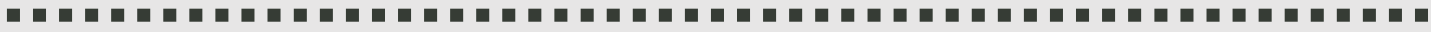

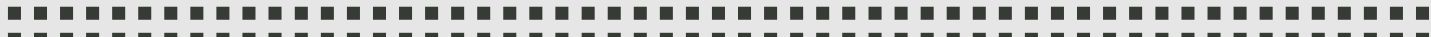

O quinto capítulo intitulado “As diversidades e as Tics na educação: uma análise inclusiva" tem como objetivo entender a relevância da valorização da diversidade e da redução da desigualdade em um determinado cenário organizacional, inclusive instituições de ensino, foco do presente estudo e sugerir mudanças pedagógicas utilizando as tecnologias de informação como meios para a existência de um ambiente organizacional que pratique a inclusão. Sabe-se que a ideia básica da gestão da diversidade em qualquer instituição é a necessidade da prática do respeito, da empatia, da inclusão e do reconhecimento de modo que um ambiente produtivo efetivamente ocorra, onde todos se sintam valorizados e os talentos sejam utilizados em plenitude realmente exista. Somente assim, as finalidades plenas daquela instituição educacional conseguirão ser atingidas.

O sexto capítulo intitulado "A Corte Constitucional Monocrática: questões sobre as decisões monocráticas em controle de constitucionalidade concentrado" o autor defende que o sistema de controle de constitucionalidade adotado pelo Brasil, que congloba tanto o modelo concentrado quanto o difuso; corrobora com o aumento indireto das competências da Corte Constitucional, entre outros. A fim de proporcionar eficiência aos julgamentos, criou-se a possibilidade de prolação de decisões monocráticas, porém questiona-se a sua legitimidade e respeito à separação dos poderes, mormente quando em ações de controle concentrado de constitucionalidade, uma vez que por decisão liminar, de um único ministro, suspende-se o efeito de Lei, processada pelo Legislativo e sancionada pelo Executivo.

O sétimo capítulo intitulado "O constitucionalismo ecológico biocêntrico sob uma análise sistemática crítica" tem como objetivo estabelecer a relação entre o ser humano e o meio ambiente, especificamente em relação à fauna, é questão recorrente no debate doutrinário, de modo que houve grandes evoluções no arcabouço jurídico pertinente. Se nos primórdios o meio ambiente não representava preocupação para o ser humano, tem-se que no sistema jurídico pátrio hodierno um verdadeiro rol de garantias aos animais, ainda que sob uma visão antropocêntrica do Constitucionalismo Ecológico. Com isto, quer-se dizer que estas garantias não representam direitos à fauna, uma vez que não são sujeitos de direitos, mas sim deveres do ser humano. Nesta toada, há movimento recente na doutrina com a finalidade de propor uma mudança de paradigma, de modo que os animais passem a ser sujeitos de direitos e possam fruir de 


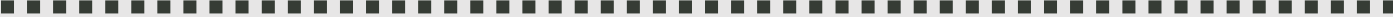

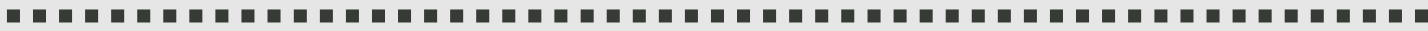

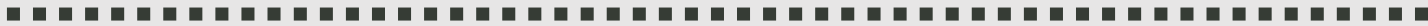

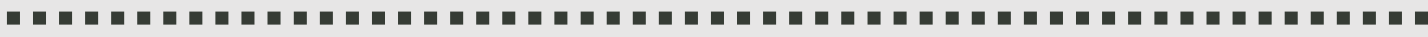

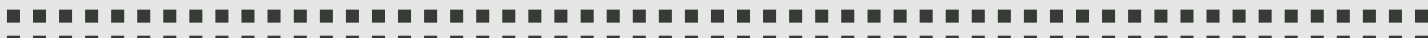

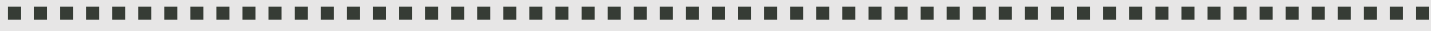

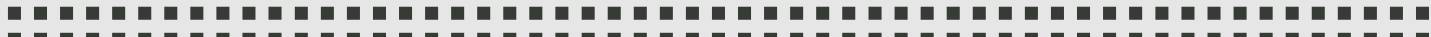

direitos fundamentais, nos moldes dos direitos garantidos ao ser humano. Portanto, relevantes questões exsurgem desse Constitucionalismo Ecológico Biocêntrico, especialmente se de fato representa avanço ao arcabouço jurídico, bem como se traz efetividade que justifique esta mudança tão profunda e os efeitos que Ihes são corolários.

O oitavo capítulo intitulado “O desmonte da política de assistência social durante o governo Bolsonaro: análise do contexto assistencial na pandemia da Covid - 19" tem como objetivo analisar o contexto de precarização e sucateamento, e com os desafios impostos pela pandemia da COVID-19 e o agravamento de algumas questões sociais, como o aumento de desemprego, amplia a inserção da população em situação de vulnerabilidade social e extrema pobreza. O atual contexto que vivenciamos é marcado por fortes ataques aos direitos sociais, somado a ampliação de trabalhos temporários, subcontratação, flexibilização, em que se tem o aumento de trabalhos desprotegidos, invisíveis às Leis trabalhistas.

O nono capítulo intitulado 'Improbidade administrativa: seus aspectos e sua denotação crítica" tem como objetivo analisar e esquematizar a questão que caracteriza a Improbidade Administrativa, em conformidade com fatores que vem ganhando espaço com desordens diante da lei. Ao exercício das atividades que são desempenhadas pelos agentes públicos e que levam a constância de razões que atentem contra a integridade, desempenhando ilegalidades com enriquecimento pessoal e violando princípios em benefício próprio, importunando assim a constitucionalidade da lei de improbidade. A Administração Pública é o alicerce para a concretização de serviços, visando à satisfação da coletividade, e é voltada para assuntos detalhados que tem como objetivo alcançar com perfeição os princípios que norteiam a administração. Aos que causem prejuízos ao erário e ao enriquecimento ilícito, consoante as suas especificidades descritas na lei, consiste em improbidade administrativa. Os que causam prejuízos ao erário e enriquecem ilicitamente se enquadram como agentes causadores da improbidade administrativa.

O décimo capítulo intitulado "Benefício Assistencial: análise das condições de miserabilidade" tem como objetivo analisar a concessão ao Benefício Assistencial. No artigo 203, V da Constituição Federal de 1988, traz a garantia da concessão de um beneficio assistencial à pessoa idosa ou deficiente que não tenha condições de prover o 
próprio sustento. Esse benefício tem regulamentação na Lei 8.742/93, conhecida como LOAS - Lei Orgânica da Previdência Social, que demonstra a acerca do benefício de prestação continuada, e institui o direito fundamental à assistência social, garantindo condições de uma sobrevivência digna àqueles que, apesar de não ter vertido contribuições previdenciárias ou tenham perdido a qualidade de segurado, não se encontram em condições de prover o próprio sustento, seja pela idade, ou em razão de alguma deficiência. Entretanto, existem requisitos para sua concessão, dentre eles o critério da miserabilidade, que cita um valor igualitário para definir quem será considerado hipossuficiente para fins do benefício de prestação continuada. Sendo assim, a fixação de um valor baixo para examinar a miserabilidade do postulante, é ferir sem sombra de dúvida esse princípio. Demonstrar-se-á, também, que o Estado não deve se afastar da sua função primordial, qual seja, promover o bem-estar de qualquer pessoa que dele necessite.

O décimo primeiro capítulo intitulado "Direito do trabalhador rural: preceitos constitucionais e direitos fundamentais" tem como objetivo analisar fontes de melhorias nas condições do trabalhador rural, na qual desempenha na agricultura uma das atividades essenciais para o desenvolvimento econômico e sustentável do país, no entanto, os trabalhadores que desempenham esta atividade não têm seus direitos trabalhistas e previdenciários devidamente resguardados e em sua grande maioria vivem e trabalham em condições precárias. Ressalta-se que no Brasil esse problema se arrasta há anos, desde a formação do país, pois o desenvolvimento da agricultura e do pastoreio não despertou o mesmo interesse do legislador em relação à regulação do trabalhador urbano. Tal observação está denominada na Consolidação das Leis do Trabalho (CLT), publicada em 1943, onde é nítida a preocupação quanto à regulação e proteção do trabalhador urbano. Ao passo que, o trabalhador rural encontra-se visivelmente excluído da esfera dessa proteção legal através da disposição do art. 70, alínea " $b$ ", da CLT. Desta feita, nasce a necessidade de investigação e análise dos motivos que geram tal precariedade dos direitos desta importante categoria de trabalhadores.

O décimo segundo capítulo intitulado "Direito tributário constitucional: a (im)possibilidade do exercício do poder judicante aos tribunais administrativos fiscais" propõe a análise acerca da possibilidade do exercício do poder judicante dos Tribunais Administrativos Fiscais, sob a ótica da Constituição Federal de 1988. 


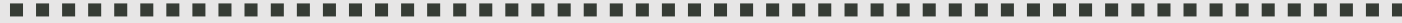

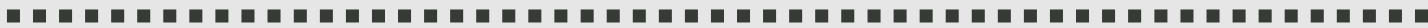

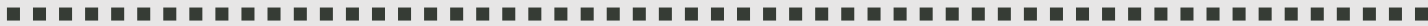

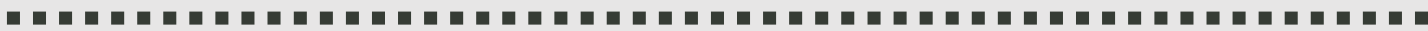

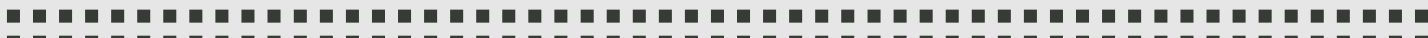

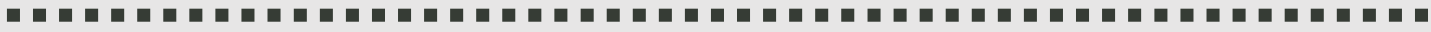

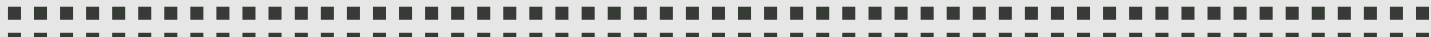

O décimo terceiro capítulo intitulado "Impacto das instituições do Direito e da Administração no trabalho no mundo pós-pandemia" tem por finalidade realizar uma reflexão sobre o impacto das instituições do direito e da administração na construção do sentido do trabalho pós-pandemia. Como elemento presente na vida do ser humano desde os primórdios de sua atuação sobre a natureza, o trabalho reveste-se de centralidade que ultrapassa a mera satisfação de necessidades econômicas e alcança outras dimensões, como a social e a de saúde física e mental. Neste diapasão, a administração e o direito do trabalho, são elencados para estudo por serem as instituições sustentadoras das relações formais e informais no mundo do trabalho. No contexto de relações sociais trabalhistas na pós-pandemia, busca-se responder à questão de pesquisa: qual o impacto das instituições Administração e Direito do Trabalho, estruturadoras das relações sociais nas organizações, após a ruptura do modo tradicional de execução do trabalho com a pós-pandemia? Essa questão é respondida mediante pesquisa bibliográfica, em um estudo exploratório, de abordagem qualitativa e de natureza básica.

O décimo quarto capítulo intitulado "A teoria argentina de Enrique del Percio sobre mudanças na sociedade contemporânea e a influência destas no envelhecimento do Perfil demográfico populacional na América Latina" tem como objetivo estudar os países da América Latina, entre eles a Argentina e o Brasil, e como têm experimentado um crescente movimento de envelhecimento do seu perfil populacional, o que decorre de sucessivas quedas nas taxas de natalidade e aumentos na expectativa de vida das pessoas. Esse movimento demográfico, tratado por alguns como "onda idosa", decorre de profundas mudanças na sociedade, em processo que foi muito bem explorado pelo professor e filósofo argentino Enrique del Percio, o qual soube analisar as alterações estruturais na sociedade ao longo dos anos, principalmente no que diz respeito ao papel das mulheres, que foi determinante para o panorama de envelhecimento vivido atualmente.

Por fim, o décimo quinto capítulo intitulado "Criação, análise, interpretação e construção dos Direitos Humanos passados e futuros a partir da revitalização e da importância da língua espanhola" tem como objetivo fazer uma síntese historiográfica da relevância do uso da língua hispânica no centro dos principais "direitos passados e futuros", acentuando os pontos de similaridade dos valores culturais atuais até à 


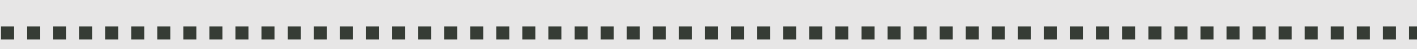

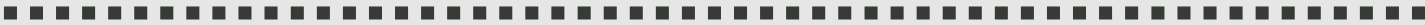

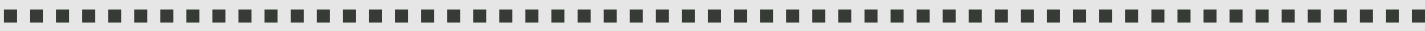
ตघG

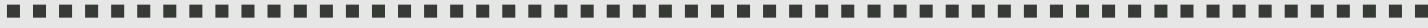

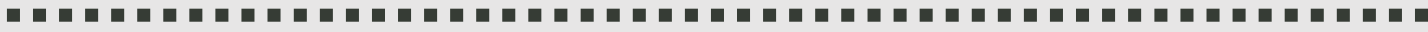

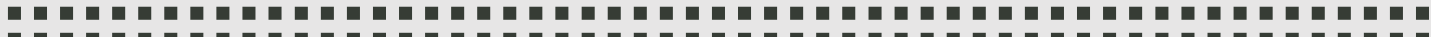

formação de blocos supranacionais e de alianças em comum. Neste passo, propõe-se uma reflexão sobre a posição de assimilação do castelhano à educação política, jurídica e econômica das próximas gerações, e a sua constante retroalimentação.

Por isso, a obra que ora se apresenta é de leitura obrigatória para estudantes e profissionais do Direito que queiram compreender e formar opinião acerca de temas jurídicos que transcendem nosso país e, diante de tais debates importantes trazidos na presente obra podem surgir soluções e respostas para a resolução de diversas questões em pauta na América Latina.

Tenham uma ótima leitura!

Das organizadoras,

Ana Silvia Marcatto Begalli Mestre em Direito pela FDSM Doutora em Educação pela Universidade São Francisco

Gabriela Soares Balestero Mestre em Direito pela FDSM Doutora em Ciências Jurídicas pela ACU Doutora em História Social pela UFU Pós Doutoranda em Direito pela Universidade de Messina 


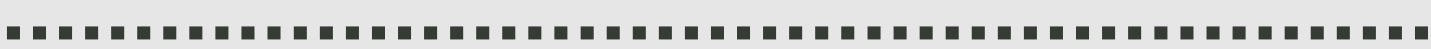

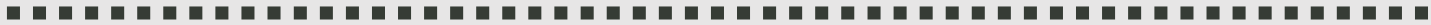

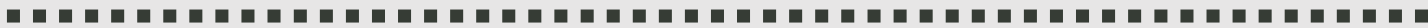

घG

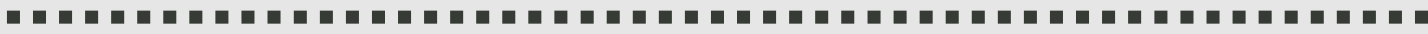

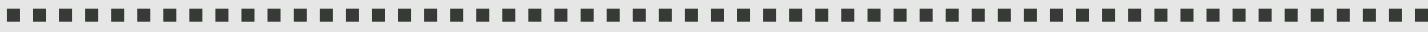

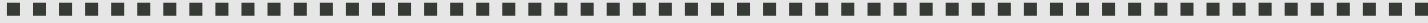

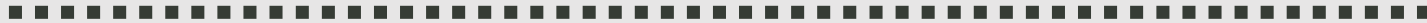

\section{SUMÁRIO}

CAPÍTULO I - POLÍTICAS PÚBLICAS E DESIGUALDADE SOCIAL NAS CIDADES BRASILEIRAS: UMA RESENHA CRÍTICA .14

CAPÍTULO II - O SEQUESTRO DO ÔNIBUS 174: A GENERALIZAÇÃO DO DIREITO PENAL DO INIMIGO ATRAVÉS DA TRAJETÓRIA DE SANDRO BARBOSA DO NASCIMENTO.

CAPÍTULO III - O LICENCIAMENTO AMBIENTAL E O PROJETO DE LEI № 2159/2021 SOB A PERSPECTIVA DO DESENVOLVIMENTO SUSTENTÁVEL.

CAPÍTULO IV - A EFICIÊNCIA DA AUTOFALÊNCIA: ANÁLISE CUSTO-BENEFÍCIO DE UM INSTITUTO ESQUECIDO NO ORDENAMENTO JURÍDICO.

CAPÍTULO V - AS DIVERSIDADES E AS TICS NA EDUCAÇÃO: UMA ANÁLISE INCLUSIVA.

CAPÍTULO VI - A CORTE CONSTITUCIONAL MONOCRÁTICA: QUESTÕES SOBRE AS DECISÕES MONOCRÁTICAS EM CONTROLE DE CONSTITUCIONALIDADE CONCENTRADO

CAPÍTULO VII - O CONSTITUCIONALISMO ECOLÓGICO BIOCÊNTRICO SOB UMA ANÁLISE SISTEMÁTICA CRÍTICA 97

CAPÍTULO VIII - O DESMONTE DA POLITICA DE ASSISTÊNCIA SOCIAL DURANTE O GOVERNO BOLSONARO: ANÁLISE DO CONTEXTO ASSISTENCIAL NA PANDEMIA DA COVID-19.

CAPÍTULO IX - IMPROBIDADE ADMINISTRATIVA: SEUS ASPECTOS E SUA DENOTAÇÃO CRÍTICA 122

CAPÍTULO X - BENEFÍCIO ASSISTENCIAL: ANÁLISE DAS CONDIÇÕES DE MISERABILIDADE 138

CAPITULO XI - DIREITO DO TRABALHADOR RURAL - PRECEITOS CONSTITUCIONAIS E DIREITOS FUNDAMENTAIS .154

CAPITULO XII - DIREITO TRIBUTÁRIO CONSTITUCIONAL: A (IM)POSSIBILIDADE DO EXERCÍCIO DO PODER JUDICANTE AOS TRIBUNAIS ADMINISTRATIVOS FISCAIS.

CAPITULO XIII - IMPACTO DAS INSTITUIÇÕES DO DIREITO E DA ADMINISTRAÇÃO NO TRABALHO NO MUNDO PÓS-PANDEMIA 184

CAPITULO XIV - A TEORIA ARGENTINA DE ENRIQUE DEL PERCIO SOBRE MUDANÇAS NA SOCIEDADE CONTEMPORÂNEA E A INFLUÊNCIA DESTAS NO ENVELHECIMENTO DO PERFIL DEMOGRÁFICO POPULACIONAL NA AMÉRICA LATINA

CAPÍTULO XV - CRIAÇÃO, ANÁLISE, INTERPRETAÇÃO E CONSTRUÇÃO DOS DIREITOS HUMANOS PASSADOS E FUTUROS A

PARTIR DA REVITALIZAÇ̃̃O E DA IMPORTÂNCIA DA LÍNGUA ESPANHOLA. 


\section{CAPITULO I}

\section{POLÍTICAS PÚBLICAS E DESIGUALDADE SOCIAL NAS CIDADES BRASILEIRAS: UMA RESENHA CRITICA}

DOI: 10.51859/AMPLLA.EDL1037-1

Thátila Larissa da Cruz Andrade ${ }^{1}$

Klécia de Sousa Marques da Silva ${ }^{2}$

1 Pós-Graduanda em Gestão em Saúde. Universidade Federal do Maranhão - UFMA

${ }^{2}$ Mestra em Saúde do Adulto. Universidade Federal do Maranhão - UFMA

\section{RESUMO}

O objetivo deste trabalho foi fazer uma resenha crítica do artigo intitulado: Globalização e desafios urbanos: políticas públicas e desigualdade social nas cidades brasileiras, publicado na Revista Eure (Santiago), no ano de 2011. O artigo foi realizado através de uma pesquisa exploratória, assentada em uma revisão literária bibliométrica com procedimento quantiqualitativo e método histórico comparativo. Tendo como objetivo, compreender os diversos ciclos de crescimento econômico evitaram uma redistribuição mais equitativa da riqueza, agravando as desigualdades sociais e empobrecendo as populações urbanas brasileiras. Os autores são taxativos ao afirmarem que quando se atribui ao Brasil uma posição quase vexatória em relação ao cenário mundial em termos de educação, trata-se, em primeiro lugar, do ensino público oferecido pelo Estado. Tal argumento também é utilizado para falar sobre questões ligadas à saúde pública e gestão sanitária. Apesar de reconhecer a potencialidade da nação, os autores pontuam que o Estado volta-se, assim, contra a elevação do nível geral de vida e a possibilidade da participação mais igualitária nos rendimentos do trabalho.

Palavras-chave: Globalização. Políticas Públicas. Desigualdade Social. 


\section{INTRODUÇÃO}

Pimenta \& Pimenta (2011), através de uma pesquisa exploratória, assentada em uma revisão literária bibliométrica com procedimento quantiqualitativo e método histórico comparativo. Sendo que, a pesquisa teve como objetivo compreender os diversos ciclos de crescimento econômico evitaram uma redistribuição mais equitativa da riqueza, agravando as desigualdades sociais e empobrecendo as populações urbanas brasileiras.

Para desenvolver a pesquisa, os autores fizeram a utilização dos descritores "Desigualdade social, pobreza, política urbana" e sua fundamentação teórica conta com a análise obras como Boal (2002), Bolaffi (1982) e Pochmann (2004). A delimitação de tal referencial já indica que os autores fariam uma análise crítica da atual conjectura.

\section{DESENVOLVIMENTO}

Um dos pontos negativos da pesquisa de Pimenta \& Pimenta (2011), é não expor de forma clara os elementos básicos de sua pesquisa. Logo, o leitor tem dificuldade para deduzir qual sua problemática, hipóteses e objetivos delineados. Apesar da fundamentação teórica ser rica em argumentação, não é possível identificar de forma objetiva se os pressupostos elegidos pela autora foram de fatos confirmados ao longo de sua obra.

Um ponto positivo, é que esses preocupam-se com o exame do processo de formação sócio histórica como condição elementar para que os atuais contornos da questão da desigualdade pudessem ser solidificados na sociedade contemporânea. Ademais, compreenda a categoria desigualdade para além das questões de distribuição de riqueza e como inerente a um processo que acaba levando a segregação parcela da população.

Quanto ao recorte histórico trazido pelos autores, destaca-se um primeiro recorte que é a consideração de que o Brasil, mesmo figurando entre as maiores nações em termos de geração de riqueza desde os anos 1980, continua a revelar elevados índices de desigualdade social. Ainda para Pimenta \& Pimenta (2011), sem apresentar qualquer delineamento de políticas que possa reverter os rumos até então adotados, no sentido da construção de uma sociedade mais equitativa. 
O trecho acima, para além de uma fundamentação teórica pode ser compreendido como um primeiro pressuposto tomado pelos autores para a construção da sua pesquisa. Tal como, ao longo de sua construção textual, esses retomam, por inúmeros momentos, a acepção de que a política e a sociedade isonômica guardam grande intimidade.

Outra contribuição que o artigo proporciona, é traça um contraponto entre formas e períodos de governo distintos. Chama-se à atenção para a referência feita ao modelo de gestão desenvolvida pelo governo populista de Vargas e, em paradoxo, a política liberal que se intensificou na década de 1990, sobretudo, com Fernando Henrique Cardoso (FHC).

Ainda que não tenham trabalhado de forma direta, é possível verificar que os autores têm a compreensão da expressão da questão social enquanto um fenômeno que impacta diretamente no modo de vida social. A ocorrência pode ser verificada quando esses percebem que as metrópoles e para as grandes cidades brasileiras aquelas que são o destino privilegiado dos destituídos que procuram suas estratégias de sobrevivência ao lado da riqueza concentrada - o desafio de superar as enormes desigualdades sociais que se desenham nos cenários urbanos (PIMENTA, 2011).

Levando em consideração a problemática específica da realidade urbana, Pimenta \& Pimenta (2011), reconhecem o processo hegemônico que é decorrente do processo de concentração de poder oriundo de um determinado modelo de produção. Assim, esses chamam à atenção para os conflitos que ocorreram quando das disputas de poder pelos Estados Unidos e Rússia e, principalmente, as consequências dessa disputa por espaço para o avanço da questão social nos centros urbanos.

Especificamente, quando do exame do processo de formação sócio histórica brasileira, Pimenta \& Pimenta (2011) reconhecem que é fundamental compreender a conjectura global e, principalmente, a dependência do Brasil de outros Estados para que se possa analisar os impactos da desigualdade urbana local. Ou seja, para além de um fenômeno cujas bases devem ser concebidas a partir de um olhar retroativo, deve-se ainda focalizar nas áreas de poder que influenciaram esse processo.

Justificando sua tese, os autores compreendem que ao longo da história de seu processo de industrialização desde meados do século XIX, o Brasil construiu um parque 
fabril dinâmico e diversificado. Realizou este percurso a partir da industrialização "em ordem inversa".

Outro ponto positivo da obra é a coleta e amostragem de dados que foram expostos através de quadros e são primordiais para a compreensão de como o país está atrás de outras nações quando se trata da matéria de desenvolvimento humano e, principalmente, quando das questões de sanitárias nos espaços urbanos. Os dados se tornam ainda mais preocupantes quando focalizados nas chamadas zonas periféricas ou saem do chamado eixo sul-sudeste.

De fato, Pimenta \& Pimenta (2011) são taxativos ao afirmarem que quando se atribui ao Brasil uma posição quase vexatória em relação ao cenário mundial em termos de educação, trata-se, em primeiro lugar, do ensino público oferecido pelo Estado. Tal argumento também é utilizado para falar sobre questões ligadas à saúde pública e gestão sanitária.

No que se refere a novas perspectivas, Pimenta \& Pimenta (2011) consideram que os diferentes governos brasileiros sempre assumiram o discurso do progresso, passando a ideia de que o país estaria melhorando constantemente, como se isso abarcasse a totalidade da nação.

\section{CONCLUSÃO}

Por fim, quando de suas considerações finais, apesar de reconhecer a potencialidade da nação, os autores pontuam que o Estado volta-se, assim, contra a elevação do nível geral de vida e a possibilidade da participação mais igualitária nos rendimentos do trabalho. Contribuindo para a concentração da riqueza em setores privilegiados.

\section{REFERÊNCIAS}

Pimenta, M. C. A; Pimenta, L. F. Globalização e desafios urbanos: Políticas públicas e desigualdade social nas cidades brasileiras, Revista Eure (Santiago), v. 37, n. 112, p. 43-61, 2011. Disponível em: https://www.scielo.cl/scielo.php?script=sci_arttext\&pid=S025071612011000300003. Acesso em: 04 jul. 2021. 


\title{
CAPITULO II
}

\section{O SEQUESTRO DO ÔNIBUS 174: A GENERALIZAÇÃO DO DIREITO PENAL DO INIMIGO ATRAVÉS DA TRAJETÓRIA DE SANDRO BARBOSA DO NASCIMENTO}

DOI: 10.51859/AMPLLA.EDL1037-2

\author{
Bárbara dos Santos Delatorre ${ }^{1}$ \\ Eduarda Castilho Rodrigues ${ }^{2}$ \\ Tatiana Mareto Silva ${ }^{3}$
}

\begin{abstract}
'Graduanda do Curso de Direito do Centro Universitário São Camilo - ES
${ }^{2}$ Graduanda do Curso de Direito do Centro Universitário São Camilo - ES

${ }^{3}$ Doutora em Direitos e Garantias Fundamentais pela Faculdade de Direito de Vitória (FDV), Mestre em Políticas Públicas e Processo pela Faculdade de Direito de Campos (FDC/UNIFLU), Pós-graduada em Direito Processual pela Faculdade de Direito de Vitória (FDV), Professora do Curso de Direito do Centro Universitário São Camilo - ES
\end{abstract}

\section{RESUMO}

Apresentamos a história de Sandro Barbosa do Nascimento, que foi marcada pela ausência de suporte estatal, culminando em um sequestro do ônibus 174 no Rio de Janeiro, tentativa do agente de ser ouvido pelas autoridades. $O$ estudo foi dividido em três etapas. Na primeira, é narrado o episódio criminoso envolvendo o transporte público. Em seguida, é exposta a história de Sandro desde sua infância, quando presenciou a morte de sua mãe a facadas até pouco antes do fatídico evento que o levou à morte pelas mãos de policiais com o objetivo de evidenciar a influência da negligência do Estado em sua formação. Por fim, é feita uma análise entre os trágicos acontecimentos ocasionados pela não efetivação das normas que dizem respeito ao direito à vida e segurança pública, bem como os requisitos básicos das garantias fundamentais, dentre eles saúde, alimentação e educação, com a tese descritiva de Günther Jakobs sobre o Direito Penal do Inimigo, que estabelece a marginalização e punição antecipada de indivíduos que insistem em violar os tipos penais, desligando-se do ser cidadão e regredindo ao chamado Estado Natural. Conclui-se que, embora o Brasil, enquanto Estado Democrático de Direito, não seja compatível com tal estudo devido ao princípio da igualdade e dignidade humana positivados na Constituição Federal de 1988, o pratica de maneira subjetiva, isto é, não reconhecidamente explícita. Portanto, o país, ao não assumir socialmente que marginaliza comunidades de baixo poder aquisitivo, acaba por ser conivente com as circunstâncias que objetivam eliminar a população miserável.

Palavras-chave: Sandro. Estado. Inimigo. Jakobs. Negligência. 


\section{INTRODUÇÃO}

Mesmo o Brasil sendo um Estado Democrático de Direito há 33 anos, ainda encontra dificuldades em compreender as consequências da omissão frente aos casos de criminalização de uma parte da sociedade, esta que, por consequência, transformase em vítima pela letalidade das forças policiais. Para chegar nos atuais cinco mil oitocentos e quatro mortos pela polícia militar no ano de 2019 , foi necessário não apenas um negacionismo estatal, mas também a colaboração da população, a qual se manteve, de maneira geral, inerte mesmo diante de situações como a candelária e vigário geral, uma vez que não houve movimentos significativos que provocassem mudanças mínimas.

Sandro Barbosa do Nascimento protagonizou um dos maiores sequestros já noticiado pela mídia, porém, após sua morte neste mesmo dia, deixou como lacuna as circunstâncias que o levaram até aquele momento: menino morador da comunidade Rato Molhado que, quando muito jovem, presenciou a morte da mãe e, por conseguinte, saiu da casa em que morava e passou a viver em situação de rua, local em que, mais uma vez, testemunhou diversas violações aos princípios humanos. Nesse sentido, percebe-se que sua trajetória pode ser analisada de maneira paralela às definições de Günther Jakobs, filósofo alemão que descreve a relação entre Estado e sociedade de modo a diferenciar os indivíduos entre sujeitos dotados de direitos que mantém vínculo com a definição de ser social que requer certas habilidades e o 'inimigo' que, por preencher requisitos como frequente deturpação das normas e até mesmo seu contexto de vida, é distanciado da categoria 'cidadã'.

Por esses motivos, é possível indagar a forma subjetiva a qual o Brasil exerce o chamado Direito Penal do Inimigo utilizando como exemplo a história de Sandro como generalização das comunidades de baixo poder aquisitivo que, de certo modo, são invisibilizadas pela sociedade e governo dada a insuficiência de políticas públicas e não efetivação das garantias fundamentais, incentivando a marginalização e a visão 'antagonista' sobre as mesmas. 


\section{REVISÃO BIBLIOGRÁFICA}

O trabalho realizado adotou a seguinte metodologia: pesquisa com abordagem qualitativa e quantitativa, com fontes bibliográficas e documentais e objetivos explicativos, discorrendo e explicando a história de Sandro Barbosa do Nascimento e a falha por parte do Estado no que concerne ao auxílio à população carente e miserável. Em paralelo, foi utilizada uma doutrina de Direito Penal como fonte principal.

Em 1985, Günther Jakobs, professor e filósofo alemão, aborda pela primeira vez a Teoria do Direito Penal do Inimigo, em uma palestra. Mais tarde, no ano de 2009, sua primeira obra sobre o tema foi lançada: "Direito Penal do Inimigo: Noções e Críticas". Nesta, debate a respeito da divisão dos seres humanos entre 'cidadãos' e 'inimigos' a partir do referencial socioeconômico e/ou insistência na prática criminosa. Na última classificação, o indivíduo é isolado da sociedade de maneira a perder sua condição de sujeito de direito, podendo (e devendo), inclusive, ser eliminado pela força do Estado.

Além disso, foi utilizado o documentário do diretor e roteirista José Padilha chamado "Ônibus 174", que relata o evento criminoso do dia 12 de junho de 2000 e a história do agente a partir de depoimentos de familiares (consanguíneos ou não) e conhecidos, que descrevem como Sandro não possuía personalidade violenta e sobre os perigos que enfrentavam durante a vivência nas ruas.

Dessa forma, possui abordagem qualitativa, pois visa avaliar e explicar os aspectos semelhantes entre os fenômenos sociais subjetivos atuais e a tese de Jakobs, além de analisar as interações do Estado através da instituição de segurança com a sociedade a partir de notícias recentemente veiculadas pela mídia sobre as operações policiais e suas consequências: chacinas.

\section{O SEQUESTRO DO ÔNIBUS 174}

Aproximadamente às $14: 30$ do dia 12 de junho de 2000 , iniciou o acontecimento que marcou a história do Rio de Janeiro e do Brasil. Um homem alto, negro e tatuado adentrou o ônibus da linha gávea, número 174, e, ao pular a catraca, deixou à mostra a arma calibre 38 que estava em sua cintura. Um dos passageiros, ao se conscientizar do iminente perigo, conseguiu escapar e informar a situação às autoridades de segurança. Logo após a abordagem policial, o motorista saiu do veículo pela janela. O meliante, ao 
constatar que o assalto havia se frustrado, passa a usar as vítimas como forma de se resguardar de possíveis investidas pelos representantes do órgão estatal.

O evento denominado "sequestro do ônibus 174" perdurou por 4 (quatro) horas. Nos primeiros momentos, não havia um cerco que afastasse os civis da cena do crime, corroborando para a aglomeração de repórteres. Ao perceber que se tornou foco das câmeras, o homem cujo nome ninguém ainda sabia passou a intensificar as ameaças contra os reféns de modo cada vez mais impetuoso. A primeira vítima a ser usada como "escudo" foi Luciana Carvalho, sendo obrigada a se sentar em seu colo. Em seguida, o sequestrador atirou contra o vidro do veículo em direção aos que estavam ali presentes. O BOPE deu início às negociações e o então Capitão André Luiz de Souza Batista tentou estabelecer comunicação com o agente nomeando-o de "Sérgio", uma vez que continuava oculto e de difícil reconhecimento por estar coberto de toalha, óculos e boné. As únicas informações que tinham sobre Sérgio eram frases confusas ditas por ele e que não foram comprovadas durante o episódio, como a alegação de ser um dos sobreviventes da chacina da Candelária em 1993, evento em que perdeu "seus irmãozinhos" (Ônibus 174, 2002).

Após algumas horas, Sérgio liberou seu primeiro refém: Willians Moura, restando sob seu domínio mulheres e um senhor de 64 anos. A segunda vítima a ficar na mira do sequestrador foi Janaina Neves, na época com 23 anos e estudante, a qual ele obrigou a escrever de batom diversas frases de ameaça como "Ele vai matar geral às 6 horas" e "Ele tem pacto com o diabo" seguidos de "Ele é louco". Quando é estabelecido o contato entre a entidade de segurança e o sequestrador, este faz pedidos de armas de fogo modelo 45, granadas tipo M-19 e dinheiro enquanto mantém uma refém como alvo de um possível disparo. Durante horas, Janaina continua sendo pressionada pelo revólver e Sérgio se mostrava volátil por ora mudar o pedido, ora afirmar que iria matar todos (ibidem).

Com a intensificação das ameaças, Damiana Nascimento Souza, 39 anos, começou a passar mal e suplicar para ser liberada; explica sua situação, conta que também é moradora de favela e possui um irmão preso, tentando, dessa forma, criar um vínculo com o assaltante, já que sabia que ele já havia sido preso. Geisa Gonçalves tenta se passar por sua filha almejando também ser permitida a sair do ônibus, todavia, a ela não foi concedido tal benefício. Damiana começa a dar sinais de infarto e, então, a 
segunda vítima, às 17:15 horas, é finalmente liberada. Durante esse processo, Janaina ainda estava sob o controle do sequestrador. Com a aproximação das 18 horas, ela foi coberta com uma toalha e, de um jeito confuso, pulando alguns números, Sérgio conta até cem, afirmando que ao final irá matar a estudante. Em seguida, a deita e dispara, fazendo com que todos os reféns corram em direção às janelas e comecem a gritar (ibidem).

Após os barulhos de disparos, a pressão sob os policiais aumentou, porém, estavam impedidos de atirar por ordens do Governador Anthony Garotinho, que não queria que os milhares de espectadores que acompanhavam o sequestro vissem um assassinato em rede nacional, mesmo que se tratasse de um "inimigo" que colocava em risco a vida de nove pessoas. Após os disparos, "Sérgio" usou outro refém: Geisa Firmo Gonçalves, de apenas 20 anos e grávida de seu primeiro filho; era professora e moradora da Rocinha. As ameaças se intensificaram ao ponto de colocar a arma na boca da refém e dizer que "uma já morreu e a outra vai morrer" (Ibidem). O sequestrador movimenta os reféns até os últimos assentos do veículo e ameaça matar outra delas, Luanna Guimarães Belmont, que na época tinha 19 anos e estudava Comunicação na PUC-RJ. Em momento posterior, utiliza o extintor de incêndio para embaçar a visão dos policiais acerca do que estava acontecendo dentro do ônibus, fazendo com que a operação policial recuasse. Em paralelo, Geisa fica em estado de pânico e é consolada pelas outras mulheres. Uma delas, a mais velha, Antônia Cardoso da Costa, oferece dinheiro e intercede para não ser assassinada. A tensão é nítida, ao passo que profissionais do BOPE orientam que Luanna tente criar vínculos de amizade com "Sérgio", como esperança de que aquele impasse tivesse um fim menos trágico que o esperado pela sociedade e profissionais que tratavam a situação (Ibidem).

\footnotetext{
Seguindo às orientações, Luanna tenta conversar com "Sérgio" Luanna conversa com Sérgio. Pergunta sobre sua irmã. Insiste em conversar. "Você sabe que dia é hoje?

"É, hoje é o Dia dos Namorados, por isso vou matar uma namorada", diz Sérgio.

"Ah, então você não vai me matar, porque eu não tenho namorado" conclui a refém.

Luanna tenta mostrar que se importa por ele (CALDEIRA, 2003).
} 
Nesse momento, outra refém, uma senhora de 72 anos, Maria Elvira Ribeiro, que estava rezando durante o sequestro, pede para se aproximar de "Sérgio" e colocar um colar de pingente religioso em seu pescoço. Seguidamente, Lourival Sebastião Nascimento, de 64 anos, é liberado e o criminoso agarra novamente a refém Geisa Gonçalves e diz que iriam "dar um passeio lá fora" (Ibidem). Luanna afirmou posteriormente que Geisa estava muito nervosa e com muito medo.

O protagonista do crime aparentemente tinha a intenção de se entregar ao descer do ônibus com Geisa, entretanto, quando Sérgio se afasta poucos metros do veículo, com a refém posta em sua frente como um "escudo", um dos oficiais da Intervenção Tática tenta disparar contra o bandido, contudo, acaba por atingir a refém e alertando o sequestrador que, por já estar com a arma engatilhada, também alveja a vítima com mais dois tiros ao cair no chão (ibidem).

Do início ao fim do sequestro, que foi amplamente coberto pela mídia, estimase que 54 milhões de brasileiros tornaram-se espectadores dos eventos daquela tarde, o sentimento gerado pelas imagens era de angústia ao passo que era impossível prever o desfecho do "sequestro". Em paralelo, não havia somente o acompanhamento pelos veículos de notícia, muitas pessoas cercavam a cena do crime como uma espécie de público em um espetáculo. Ao final do "show", a multidão avança sobre o agente criminoso com o intuito de promover uma espécie de vingança a partir do linchamento. Inclusive, o companheiro da refém baleada tentou chutá-lo.

Embora com toda a desordem, "Sérgio" anda, empurrado, até a viatura policial, local em que foi morto asfixiado por militares da operação. Enquanto isso, as reféns restantes se encaminharam para fora do veículo, incluindo Janaína Neves, que todos achavam que estava morta pelos disparos, contudo, apenas permaneceu deitada durante o decorrer do sequestro, deixando claro que a intenção do agente não era deixar vítimas, mas chamar a atenção da instituição de segurança estatal.

No dia seguinte, a pergunta que pairava era "quem é Sérgio?". A dúvida acerca da identidade do sequestrador perdurou por mais 27 dias após sua morte, sendo identificado como Sandro do Nascimento com base nos registros de impressões digitais do IFP (Instituto Félix Pacheco). Segundo o órgão, Sandro já apresentava duas acusações por furto e assalto a mão armada. Apenas uma mulher que alegava ser a mãe do jovem reclamou o direito de enterrá-lo; Elza da Silva, 45 anos de idade, apresentou-se no IML 
informando que o nome do sequestrador era Alessandro da Silva e era seu filho, o que após os exames de DNA descobriu ser um engano. Como resultado, ao final do trigésimo segundo dia o jovem é finalmente enterrado, mas, devido às dúvidas acerca da sua identidade, sua certidão de óbito é expedida como indigente e é enterrado em cova rasa. A única "familiar" a comparecer ao seu enterro foi dona Elza.

\section{0 SEQUESTRADOR}

Sandro Barbosa do Nascimento nasceu em 1978, filho de Clarice e de pai desconhecido. Junto com a família, viveu na comunidade do Rato Molhado, em São Gonçalo-RJ, até os 6 anos, onde sua mãe possuía um bar que era fonte da renda familiar e, posteriormente, tornou-se raiz dos seus traumas. Neste, Clarice foi esfaqueada e morreu na presença de seu filho. A irmã de Clarice, Julieta, narrou para o documentário do roteirista José Padilha o traumático cenário que encontrou ao chegar no local e ver seu sobrinho.

Fecho o olho e vejo como foi a cena de Sandro ter visto aquelas três pessoas agredindo a mãe dele, esfaqueando a mãe dele, e eu tenho a impressão que ele ficou com a mãe dele sofrendo, com a faca nas costas, entendeu? Ele viu a faca nas costas da minha irmã, tenho certeza que ele viu (NASCIMENTO, Julieta. Ônibus 174, 2002).

Após a tragédia, Sandro passou a morar com a tia, entretanto, devido à proximidade com a região em que sua mãe foi morta, o menino escolheu viver em situação de rua, sendo uma forma de fuga dos eventos presenciados. Próximo à Igreja da Candelária, conheceu sua "nova família" e encontrou sentimento de pertencimento; recebia auxílio através da artista plástica e atriz Yvonne Bezerra de Mello. Segundo ela, Sandro "era calado, quietinho, era um menino que sempre morou em casa com a mãe, nunca tinha se metido em complicação nenhuma, uma criança normal que teve a vida cortada por um ato violento" (G1-RJ, 2015).

O perigo era constante para os jovens de rua, principalmente durante a noite, em que deveriam dormir em locais mais escondidos e afastados pois havia casos em que indivíduos que passavam pela avenida pegavam paralelepípedos no chão para jogar na cabeça desses que descansavam sem saber que não iriam mais acordar (Ônibus 174, 2002). Ademais, com a presença constante da fome, Sandro ainda era muito jovem quando passou a fazer o uso de entorpecentes, forma muito utilizada para amenizar a 
falta de alimentos (Ibidem). Como ainda não havia políticas públicas que objetivassem o bem-estar da criança e do adolescente, no entendimento da advogada Maria Helena Bragaglia apud $\mathrm{PINHO}^{1}$, os jovens de rua eram vistos apenas como objeto de intervenção do Estado e não sujeitos de direitos. Dessa forma, o movimento estatal em relação a esses meninos era força a Policial, de modo que recolhiam e os colocavam em abrigos. Dado que muitos realizavam furtos ou outros crimes de menor potencial para conseguir se alimentar ou para manter os vícios, alguns encontros com os agentes de segurança transformavam-se em conflito.

Segundo a Psicologia, a adolescência é um período de busca por identidade, estando propenso o indivíduo às influências externas que intervêm na formação social e cognitiva, ou seja, na forma como se relacionam e expressam seus sentimentos (ANDREATTA; OLIVEIRA, 2005, p. 129-130 apud OLIVEIRA; TURECK, 2019 p. 4). No que tange à história de Sandro, os meninos de rua, ao invés de terem amparo estatal, acabaram excluídos pela sociedade na fase da adolescência e expostos ao mundo da criminalidade, algo que, a partir do referencial psíquico, contribuirá para a formação da identidade desses sujeitos. Isso posto, é formado o pensamento popular de que meninos como os da candelária são causadores de problemas sociais, afinal, seu desenvolvimento é cercado por mais intervenções negativas que positivas. Nas palavras de PREUSSLER e CORDAZZO, 2018:

[...] na modernidade recente, delinquentes escolhem voluntariamente a criminalidade, sem qualquer influência de circunstâncias sociais, ou seja, são vistos como a causa de todos os problemas da sociedade, quando na verdade os seus problemas é que são causados pela própria sociedade, que desampara, criminaliza e estigmatiza grupos vulneráveis (PREUSSLER; CORDAZZO, 2018).

Aos 16 anos, Sandro cumpria sua quarta medida socioeducativa no Instituto Padre Severino, local reconhecido pelos diversos casos de violência, fugas, homicídios, dentre outras formas de negligências notáveis, como no episódio do ano de 1997, em que uma das fugas teve como consequência a morte de seis pessoas devido ao incêndio causado. Além disso, em 1999, o então diretor administrativo do instituto foi preso por abusar sexualmente de jovens que estavam sob custódia do Estado e, em 2008, o Ministério Público denunciou diversos agentes do reformatório pelo homicídio doloso de um adolescente. 
Enquanto Sandro estava perante responsabilidade do Instituto, sua tia Julieta realizava algumas visitas, às quais relata no documentário de José Padilha:

Eu fiquei assim arrasada. Quando eu cheguei lá, eu chorava e o pessoal ainda
ria da minha cara. Eu chorava porque não era nem preocupada com as outras
crianças que tava lá que eles passavam e batiam com cassetete na mão das
crianças. Aí eu falava assim "Gente, essas crianças quando sair daí vai, vai sair
pior, porque não tem um apoio, não tem um carinho. Acho que violência, né?,
o mundo já é violento, você vai e bota numa instituição a criança lá e maltrata
e vão sair pior (entrevista de Tia Julieta para o documentário ônibus 174.
2002 . 00:44:43)

Quando na maioridade, Sandro continuava dependente químico, sequenciando em habitualidade nas práticas de furto para manter os vícios, provocando dois indiciamentos: um por furto qualificado e outro por tentativa de assalto. $\mathrm{O}$ cumprimento da pena foi delimitado para Vigésima sexta Delegacia de Polícia, popularmente nomeada de "o cofre" pelos detentos por não haver a possibilidade de banho de sol. No documentário Ônibus 174, um dos carcereiros que conheceu o Sandro relata que nas celas as quais o limite era de dez detentos, a média chegava a 25 pessoas, tornando-se ainda mais insuportável devido ao calor e à pouca circulação de ar no local. Em 1999, Sandro, juntamente com outros detentos, conseguiu fugir da instituição, fato relatado pelo carcereiro Mendonça:

O Sandro veio na onda, como tinha vagabundo aí na onda, porque eles
entenderam que a cadeia estava aberta, calhou de estar numa cadeia dessa,
aproveitou a onda e foi embora. Porque a única oportunidade que tinha para
fugir. Então até quando ele passou por mim, ele fez assim sabe tipo: "Pô,
tenho que ir, a oportunidade é essa e foi embora" (Mendonça para o
documentário ônibus $174,2002,01: 01: 00$ ).

Após a fuga, Sandro passa a morar no bairro Nova Holanda, onde conhece a Dona Elza, que havia tido um filho com o nome Alex, com quem perdeu contato ao completar 4 anos. A última informação que obteve era de que o menino estava em "situação de rua". Devido a semelhança entre a história de vida e os nomes fictícios Alex e Alessandro que Sandro utilizava, uma relação de mãe e filho é estabelecida entre ambos. Ela relata que Sandro tinha vontade de começar estudar e trabalhar, que queria encontrar a "Tia Yvonne" para que ela pudesse ajudá-lo. Em seu depoimento, Dona Elza carrega um tom maternal ao expor que o jovem realmente queria mudar de vida. 


\title{
5. A TEORIA DESCRITIVA DE JAKOBS E A SOCIEDADE BRASILEIRA
}

Em 1985, Gunther Jakobs, jurista alemão, traçou a teoria do Direito Penal do Inimigo que, embora ainda seja discutida por doutrinadores no que cerca sua abordagem, este afirmava tratar-se de "instrumento idôneo para descrever um determinado âmbito, de grande relevância, do atual desenvolvimento dos ordenamentos jurídico penais" (JAKOBS, 2012, p. 52), definição a qual será utilizada para a discussão a seguir, ou seja, sua vertente descritiva. O doutrinador alemão pretendeu distinguir a figura do autor em dois polos, em que o primeiro representaria o direito penal do cidadão, punido somente quando exteriorizada a conduta criminosa, tendo ainda sua esfera privada apartada do direito penal e, no outro vértice, estaria o direito penal do inimigo, no qual o indivíduo seria criminalizado previamente, isto é, sem que, de fato, tenha ocorrido lesão ao bem jurídico (GRECO, 2005), posto que seria classificado como alguém de extrema periculosidade devido a sua habitualidade nas condutas criminosas e, dessa forma, estaria agindo conforme seu "Estado Natural" (Ibidem).

\begin{abstract}
Para Jakobs, há pessoas que, por sua insistência em delinquir, voltam ao seu estado natural antes do estado de direito. Assim, segundo ele, um indivíduo que não admite ser obrigado a entrar em um estado de cidadania não pode participar dos benefícios do conceito de pessoa. E é que o estado natural é um estado de ausência de norma, quer dizer, a liberdade excessiva tanto como de luta excessiva. Quem ganha a guerra determina o que é norma, e quem perde há de submeter-se a essa determinação (Ibidem).
\end{abstract}

Para Gunther Jakobs (1985 apud Mendes, 2011), o agente classificado como inimigo perderia o atributo de 'pessoa' por este ser um conceito social. Nesse sentido, o ser humano compreende um processo natural a qual todos são abarcados, ou seja, o cidadão, na condição de pessoa, carrega com si direitos e deveres e, assim, desempenha uma função social; já o inimigo, estaria deslocado do papel que deveria cumprir, juntamente com as expectativas normativas que os cercam, logo, representando um regresso ao Estado Natural, caracterizado pela ausência de normas, o que demonstra a influência de Thomas Hobbes ${ }^{1}$ na teoria de Jakobs. À vista disso, aquele que delinque deverá ser impedido por, além de colocar em risco um bem tutelado pelo direito penal, também ofender o ordenamento jurídico como um todo.

\footnotetext{
${ }^{1}$ (1588-1679). Teórico político e filósofo inglês autor de "Leviatã”, obra em que expõe sua visão sobre a sociedade sempre ser ameaçada por uma guerra civil, logo, a população vive em uma situação de constante conflito: "uma guerra de um contra todos e de todos entre si" (FRAZÃO, 2021).
} 
Nessa perspectiva, é possível traçar um paralelo entre a trajetória de Sandro até o momento mencionado e uma adaptação da teoria abordada por Gunther Jakobs sobre o tratamento estatal em relação a esses indivíduos marginalizados: o chamado Direito Penal do Inimigo. Em harmonia com o filósofo e professor, tanto a sociedade quanto o próprio Estado tendem a enxergar tais pessoas como inimigas pela sua condição socioeconômica e influências, isto é, ao considerar o protagonista deste estudo, nota-se que, a partir do momento em que se insere na marginalidade e persiste na violação de tipos penais, deixa de ser cidadão e transforma-se em algo que deve ser eliminado, como exemplifica GRECO (2005) ao citar Jakobs, estabelecendo que o oponente do Estado não deve ser tratado como sujeito de direitos uma vez que não mais se encontra em situação de civilidade, isto é, passam a não serem considerados como pessoas, mas como algo que oferece perigo à organização social, devendo, assim, ser neutralizado (JAKOBS, 1985 apud GRECO, 2005. p. 218).

Se nós acrescentarmos a invisibilidade, o drama natural da adolescência, nós
compreenderemos, como difícil é esse trânsito, essa trajetória desse menino,
do Sandro qualquer da vida pela cidade. Esse ser invisível. Nossa sociedade
define esses seres humanos, não como seres humanos, mas como lixo da
sociedade. Então eles são lançados em pocilgas e nós nos
desresponsabilizamos inteiramente por eles (Sociólogo para o documentário
ônibus 174, 2002, 00:40:15).

A visão de Sandro Barbosa do Nascimento como antagonista, juntamente com os outros meninos de rua, se torna explícita no ocorrido dia 23 de julho de 1993 em uma operação policial que provocou a chamada Chacina da Candelária. Neste episódio, as autoridades que deveriam resguardar a população realizaram uma série de disparos de arma de fogo contra os jovens com o intuito de eliminar os menores miseráveis e, em paralelo, se vingar por um evento dos dias anteriores em que um adolecente quebrou o vidro da viatura da patrulha do $5^{\circ}$ Batalhão da Polícia Militar ao arremessar uma pedra. Soma-se a isto, a crença de que, sendo tal batalhão conhecido como "esquadrão da morte" com envolvimento no tráfico de drogas, pretendiam um "acerto de contas" com os meninos que também estavam nessa esfera criminosa (SOUSA, 2019).

Após perder membros da família a qual pertencia na Chacina da Candelária, Sandro passou a se movimentar constantemente, já não ficava em um só local, assim como outros sobreviventes. Antes da chacina havia em torno de 70 crianças, entretanto, 
a ativista Yvonne Bezerra, em entrevistas posteriores, afirmou acreditar que a maioria que presenciou o atentado de 1993 está morta.

\begin{abstract}
A maioria está morta. Eu tenho o mesmo número de telefone e meu último contato com eles foi há 4 anos. Um morreu de bala perdida na Maré e uma menina morreu de doença, ela já tinha problemas. Os outros, talvez um esteja vivo, o Sérgio, que era testemunha. Os outros, se estivessem vivos, entrariam em contato comigo (Yvone para Agência Brasil, 2018).
\end{abstract}

Frente a esses casos de abuso de poder policial, os cidadãos brasileiros ainda enfrentam dificuldades em entender o Estado de direito que deveria ser garantido. A melhor simbologia do pensamento que inflama a mente da sociedade seriam as palavras de Patrícia, irmã de uma das vítimas da candelária, que posteriormente tornou-se ativista: "A população pede chacinas, principalmente quando não são com seus filhos. Se está morrendo na mão da polícia é porque alguma coisa errada estava fazendo. Até descobrir que não é isso" (G1, 2015).

Nesse sentido, quando se fala em marginalização diz-se que tal comunidade de rua, sociologicamente, se encontra desprezada pelo corpo social por serem considerados "inferiores" ou, moldando as definições elaboradas por Jakobs, "não pessoa", isto é, acabam sendo penalizadas "por não se adequar ao padrão social constante da norma" (DA SILVA; TEMELJKOVITCH, 2018). Dessa maneira, entende-se que a punição é aplicada ao indivíduo, mas não por sua conduta, e sim pelo que ele é e representa, mesmo que ainda não tenha praticado o crime, apenas pela presunção de ação criminosa de acordo com as influências externas recebidas pelo sujeito (Ibidem).

\footnotetext{
A afirmativa de Jakobs de que ainda assim não é possível fazer com o inimigo o que se bem quiser, pois ele seria dotado de "personalidade potencial", de modo que não seria permitido ultrapassar a medida do necessário, não é uma solução, mas justamente o problema. Afinal, quem é tratado apenas segundo considerações de utilidade e necessidade não é uma pessoa, e sim uma coisa. Aqui será tão impossível falar limites morais absolutos quanto o é no trato com quaisquer objetos do direito das coisas, entre os quais o autor foi claramente jogado. (GRECO, 2005)
}

Inclusive, o próprio documentário “Ônibus 174" de José Padilha expõe, a partir de uma análise do sociólogo Luis Eduardo, a visão do bandido como uma espécie de câncer social que foi combatido na fase terminal ao invés de na origem, como no suporte/auxílio às populações carentes e efetivação dos órgãos de segurança pública que se constituíram como as falhas que moldaram a trajetória de Sandro. 
Quando tinha quinze anos arrancaram a cabeça da minha mãe, tá ligado? Fiz a 26, não tenho nada pra perder. Vou pôr a porra dessa chapa pra esquentar. (...) Ó, isso aqui não é filme de ação não, hein! Aqui o bagulho é sério, meu irmão. (...) Vocês botaram a chapa para esquentar lá em vigário, não botaram? Vocês mataram meus irmãozinhos da Candelária e eu tava lá, eu vi. Se você não tava lá, então sai fora! (Discurso de Sandro para os policiais, 2002, 00:26:26).

O Brasil, como Estado Democrático de Direito, à luz do princípio da dignidade humana seria totalmente incompatível com a admissão do direito penal do inimigo de Günther Jakobs, todavia, como já exposto, o doutrinador alemão conceitua sua obra como descritiva pelo fato da sociedade, de maneira subjetiva, já aplicar tal tese. Com a crescente dos movimentos que buscam pelo punitivismo, como o 'Lei e Ordem' ${ }^{1}$, para o filósofo, seria perigoso não delimitar quem de fato estaria à mercê de sofrer as consequências do direito do inimigo, uma vez que para o autor, nem todo delinquente é um adversário do ordenamento jurídico (JAKOBS, 2012, p. 28). Portanto, quando delimitado o antagonista, em observância aos preceitos do estado democrático de direito, seria a melhor forma de conter os avanços punitivistas (Ibidem, p. 32).

\title{
O doutrinador Brasileiro Rogério Greco, ao criticar enfaticamente o
} posicionamento de Jakobs, expõe as controvérsias da teoria que, em sua concepção, defender a aplicação da teoria alemã seria uma forma de se desfazer dos avanços sociais democráticos estabelecidos até agora, porque assumir a possibilidade de um inimigo do estado legitima características de sistemas autoritários, uma vez que rompe com o limite do poder estatal de punir.

\begin{abstract}
Não podemos afastar todas as nossas conquistas que nos foram sendo dadas em doses homeopáticas ao longo dos anos, sob o falso argumento do cidadão versus inimigo, pois que, não sendo possível conhecer o dia de amanhã, quem sabe algum louco chegue ao poder e diga que inimigo também é aquele que não aceita a teoria do Direito Penal do Inimigo, e lá estarei eu sendo preso, sem qualquer direito ou garantia, em troca de um argumento vazio e desumano (GRECO, 2012).
\end{abstract}

Se analisado o direito penal do inimigo como um conceito descritivo, percebe-se que há a sua aplicação quando na omissão do estado brasileiro, uma vez que certos grupos são criminalizados ao ponto de ser negado seu status de pessoa de tal modo que possam ser eliminados, bastando a justificativa fútil de que tenham resistido ao auto de

\footnotetext{
${ }^{1}$ Movimento político-criminal que enxerga o Direito Penal como protetor de, basicamente, todos os bens existentes na sociedade e, por consequência, aumenta os tipos penais, ampliando os passíveis de tornarem-se criminosos, por menor que seja a ofensa ao bem jurídico (Direito penal do Inimigo, JusBrasil, 2012)
} 
prisão ${ }^{1}$, que os agentes militares o confunda com bandidos em perseguição ${ }^{2}$ ou até mesmo quando a confusão recai sobre objetos como guarda-chuva ${ }^{3}$ e ferramentas 4 .

Dessa forma, se obtém o resultado de 5804 mortes por policiais em 2019 (G1, 2020). O fator 'cor' também deve ser levado em consideração no debate, isso porque $78 \%$ dos mortos pela polícia são negros $(G 1,2021)$.

O governo brasileiro nem sempre se portou como omisso, mostrando-se também agente legitimador, como na gestão política de certas personalidades, à exemplo o general Nilton Cerqueira, o qual assumiu o cargo de secretário de segurança pública do Rio de janeiro (1995) e, baseado em ideais positivistas, criou uma compensação pecuniária para policiais por ato de bravura. Assim expõe as pesquisas do Laboratório de análise da violência coordenado pelo pesquisador Ignacio Canon (2003) e evidenciados pelo artigo de Robson Rodrigues:

\begin{abstract}
À percepção de que a criminalidade se proliferava pela leniência de políticos da esquerda, no caso o ex-governador Leonel Brizola, Cerqueira respondeu, criando uma premiação pecuniária para "atos de bravura" de policiais que se arriscassem no combate ao crime, logo apelidada de "gratificação faroeste" por estimular na verdade a morte do inimigo (Cano 2003). O resultado foi uma das mais duras e sangrentas repressões que o estado vivenciou, com o consequente aumento das taxas de homicídios e dos polêmicos autos de resistência[...] Em 1995 houve o pico de 61,8 homicídios por grupo de 100 mil habitantes no estado e, em 1997, foi a vez da capital chegar ao ápice dos 53,7 homicídios por 100 mil habitantes (RODRIGUES, 2014).
\end{abstract}

Tal posicionamento imerso na ideologia punitivista, tornou-se uma "Marca registrada" dos que ocuparam a cadeira presidencial nas últimas décadas, como por exemplo o pronunciamento do ex-presidente Luiz Inácio Lula da Silva no ano de 2007 em relação ao tráfico de drogas do Rio Janeiro que, segundo expõe os autores Alexandre da Cruz e Ilka Ferrari, diz: “Essa barbaridade que aconteceu no Rio de Janeiro não pode

\footnotetext{
${ }^{1}$ Lucinaldo Ferreira de Nazaré, de 23 anos, foi morto pela polícia em fevereiro de 2021 com ferimentos de, ao menos, seis tiros nas costas, tórax e pernas durante o cumprimento de um mandado policial por tráfico de drogas e suspeição de este liderar uma facção criminosa (Diário de Manauara, 2021).

2 Em 2019, militares fuzilaram com 80 tiros o carro de uma família no Rio de Janeiro por engano durante uma perseguição (Folha de S. Paulo, 2019).

${ }^{3}$ Segundo o jornal de renome EL PAÍS, Alexandre da Silva Serrano foi morto com três tiros da Polícia Militar enquanto esperava a chegada de sua família por uma confusão que foi feita acreditando ser um fuzil o guarda-chuva que segurava (EL PAÍs, 2018).

${ }^{4}$ Em 2015, dois jovens foram alvejados e mortos pelo Sargento da PM por confundir ferramenta com arma $(G 1,2015)$. Outra situação é a de João Victor, que trabalhava como DJ e montagem de equipamento de som e teve sua furadeira confundida com uma arma durante o tiroteio na comunidade de Santa Maria, Zona Oeste do Rio de Janeiro, em abril de 2019, uma operação policial que visava controlar o tráfico da região (O Dia, 2019).
} 
ser tratada como crime comum. Isso é terrorismo e tem que ser combatido com a política forte e mão forte do Estado brasileiro". O atual presidente, Jair Messias Bolsonaro, também externalizou discursos desse mesmo cunho em suas redes sociais, em que parabenizou um dos maiores episódios de execuções policiais do Estado do Rio de Janeiro: "Ao tratar como vítimas traficantes que roubam, matam e destroem famílias, a mídia e a esquerda os iguala ao cidadão comum, honesto, que respeita as leis e o próximo". Nota-se, portanto, que tais declarações divergem da posição ocupada, uma vez que a Carta Magna pátria veda a pena de morte (com exceção ao estado de guerra declarado). Em harmonia com arguições do Ministro do STF, Edson Fachin, outra figura emblemática que se destaca pela arbitrariedade no combate ao tráfico sem respeitar qualquer forma de "padrões mínimos de razoabilidade e proporcionalidade, como os estabelecidos pelos Princípios Básicos sobre o Uso da Força e Armas de Fogo pelos Funcionários Responsáveis pela aplicação da Lei" (Conjur, 2019) são os representantes do órgão de segurança pública.

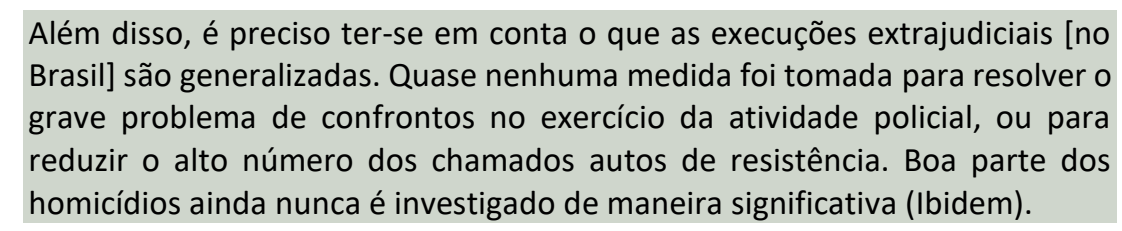

Nessa lógica, Sandro Barbosa do Nascimento, ao ser encaminhado para a viatura policial após o sequestro do veículo público, foi morto asfixiado por policiais da operação que se justificaram com o argumento de que foi um 'auto-asfixiamento' e, no julgamento por homicídio, foram absolvidos em tribunal popular. Isso posto, pode-se dizer que o Brasil, assim como é omisso em diversas questões, também o é quando instituições que o constituem são arbitrárias quanto à utilização de seu poder e/ou influência. Assim expõe Luiz Eduardo De Vasconcellos Figueira o pensamento de Paulo Rangel em sua tese de doutorado: "No júri os iguais não julgam os iguais, basta verificar a formação do Conselho de Sentença: em regra, funcionários públicos e profissionais liberais. E os réus? Pobres. Normalmente traficantes de drogas e, excepcionalmente, um de nós" (RANGEL, 2003, p. 477).

Segundo Aristóteles apud Michael J. Sandel, o que difere os seres humanos dos animais é, não somente a capacidade de raciocínio, mas a de expressão dos sentimentos, a linguagem, pois esta registra e expressa "o que é justo ou injusto, 
distingue o certo do errado" (SANDEL, 2020). Dessa maneira, os "Sandros" sociais, sabendo que, psicologicamente são moldados pelas influências exteriores durante a fase da adolescência, depois de tantos eventos vivenciados e ineficácia de auxílio estatal, acabam não vendo outra maneira de se expressar senão através de violência, visto que cresceram e foram formados a partir dela.

\begin{abstract}
Se a virtude moral é algo que aprendemos com a prática, devemos, de alguma forma, desenvolver primeiramente os hábitos corretos. Para Aristóteles, este é o princípio primordial da lei - cultivar hábitos que façam de nós indivíduos de bom caráter. "Os legisladores tornam os cidadãos bons ao incutir-lhes bons hábitos, e é isto que todo legislador deseja; aqueles que não o fazem não atingem seu objetivo, e é aí que uma boa Constituição difere de uma ruim". A educação moral está menos relacionada com a promulgação de leis do que com a formação de hábitos e a construção do caráter. "Não faz pouca diferença (...) se cultivarmos hábitos de um tipo ou de outro desde muito jovens; faz muita diferença, ou melhor, faz toda a diferença." (Sandel, 2020 apud Aristóteles, 1925).
\end{abstract}

Portanto, não podem ser caracterizados como "não-pessoas", posto que, além de possuírem personalidade humana, foram moldados pela própria sociedade e, se quisessem um indivíduo de virtude moral, deveriam desenvolver bons hábitos e cultiválos, bem como os legisladores e, por extensão, os órgãos públicos.

\title{
6. CONSIDERAÇÕES FINAIS
}

Diante dos fatos apresentados, conclui-se que Sandro Barbosa do Nascimento, após uma tragédia, sofreu diversas mazelas da falta de políticas públicas e foi invisibilizado pelo corpo social, de modo que a primeira intervenção estatal que o tocou foi a visão coletiva de que era fonte de problema para a segurança da comunidade, ou seja, sem antes enfrentar as causas que corroboraram para eventos como a candelária, a sociedade foi confrontada por indivíduos que foram transformados em inimigos por ela mesma. Dessa forma, se a violência desenfreada pelo Estado que, nas entrelinhas revoga o status de "pessoa" de uma parcela da população devido aos estigmas de cor ou condição socioeconômica, for a única forma de garantir uma pseudodefesa, então estaremos diante do chamado pelo popular de "remédio que mata o paciente"1.

É incompatível, assim, dizer que o Estado é arbitrário pois este é o conjunto de instituições públicas, entretanto, é representado por pessoas, e estas são arbitrárias e

\footnotetext{
${ }^{1}$ Ditado popular referente à solução que posteriormente causa o problema.
} 
que, como demonstrado, em situação de poder, acabam por utilizá-lo de maneira a propagar seus próprios ideais, dificultando a justiça moral e deturpando a justiça processual que abarca todos os indivíduos em contexto igualitário. Sendo assim, a proposta é que haja maior contato com o grupo social a fim de analisar suas necessidades, além de, no que tange à segurança, ser investido em equipamentos tecnológicos que evitem o confronto violento ao proporcionar uma ação tática, como a utilização de câmeras em drones para um maior mapeamento e impedir episódios de confusão de itens domésticos com armamento. Outro fator para operações de defesa seria o policiamento comunitário, que se baseia na interação entre comunidade e polícia, sendo uma forma de recuperar a relação entre a força armada do estado com uma parcela da população que foi muito abusada pelas pseudo intervenções pacificadoras. Nesta opção, o cidadão-policial atuaria na prevenção do crime diretamente em sua comunidade e, paralelamente, a polícia faria rondas constantes, visitando locais públicos como igrejas, escolas, comércios, dentre outros, formando, assim, um laço de confiança com a população.

Nessa lógica, seria simplista discorrer que é necessário a efetivação das normas ou incentivo à políticas públicas voltadas ao auxílio às comunidades mencionadas, pois isso não acontecerá enquanto a população cultivar o mesmo pensamento, isto é, a mudança não deve ocorrer pura e meramente por parte do Estado, mas pela noção de que, ao pertencer a um Estado Democrático de Direito, as garantias de outrem são suas próprias garantias caso estivesse na mesma situação, ou seja, a mudança deve partir da sociedade.

\section{REFERÊNCIAS}

CALDEIRA, Cesar. Mancha na cidade do Rio de Janeiro: a trajetória de um DA SILVA, Camila R. et al. Estados não sabem raça de mais de $1 / 3$ dos mortos pela delinquente notável. Brasília a. 40 n. 159. 23 fls. jul./set. 2003.

CRUZ, Alexandre; FERRARI, Ilka. O Inimigo nosso de cada dia: uma interlocução entre psicanálise e direito. Revista Ágora - Estudos em Teoria Psicanalítica. Rio de Janeiro. $v$ XXI. n. 2. pags. 169/180. Agosto de 2018. Disponível em: <https://www.scielo.br/j/agora/a/NDJZ44XB4qnhPgpR9GFXmcz/?format=pdf\&l ang=pt>. Acesso em: 30 mai. 2021 
DA SILVA, Leonardo V.; TEMELKOVITCH, Kime. Direito Penal do Inimigo. Publicação independente, ISBN: 9781718174580. 2018.

Especial sobre ônibus 174 lembra erro de PM e narra a vida de Sandro. G1. Rio de Janeiro, 2015. Disponível em: <http://g1.globo.com/rio-dejaneiro/noticia/2015/06/especial-sobre-onibus-174-lembra-erro-de-pm-enarra-vida-de-sandro.html>. Acesso em: 27 mai. 2021

ÔNIBUS 174. Direção: José Padilha. 133 min. Rio de Janeiro: Riofilme, 2002.

FIGUEIRA . Luiz Eduardo de Vasconcellos.O ritual judiciário do tribunal do Júri. Tese. Universidade Federal Fluminense Programa de Pós-graduação em Antropologia. Niterói. pag. 125, 2007. Disponível em: <http://ppgantropologia.sites.uff.br/wpcontent/uploads/sites/16/2016/07/LUIZ-EDUARDO-DE-VASCONCELLOSFIGUEIRA.pdf>. Acesso em: 30 mai. 2021.

FRAZÃO, Dilva. Thomas Hobbes: filósofo e teórico político inglês. Ebiografia, 2021. Disponível em: <https://www.ebiografia.com/thomas_hobbes/>. Acesso em: 30 mai. 2021.

GRECO, Luis. Sobre o chamado direito penal do inimigo.Revista da Faculdade de Direito de Campos, Ano VI, № 7 - 2005. Disponível em: <http://fdc.br/Arquivos/Mestrado/Revistas/Revista07/Docente/07.pdf>. Acesso em: 30 mai. 2021.

GRECO, Rogério. Direito Penal do Inimigo. JusBrasil, 2012. Disponível em: $<$ https://rogeriogreco.jusbrasil.com.br/artigos/121819866/direito-penal-doinimigo>. Acesso em: 27 mai. 2021.

Homem é morto pela polícia após resistir à prisão em Faro, no PA. Diário de Manauara, 2021. Disponível em: <https://diariomanauara.com.br/policia/homem-e-mortopela-policia-apos-resistir-a-prisao-em-faro-no-pa/>. Acesso em: 30 mai. 2021.

JAKOBS, Günther; MELIÁ, Manuel C. Direito Penal do Inimigo: Noções e Críticas. 6ạ ed. Porto Alegre: Livraria do Advogado Editora, 2012.

MOURA, Carolina. PM confunde guarda-chuva com fuzil e mata garçom no Rio, afirmam testemunhas. EL PAÍs, 2018. Disponível em: <https://brasil.elpais.com/brasil/2018/09/19/politica/1537367458_048104.ht ml>. Acesso em: 30 mai. 2021.

NITAHARA, Akemi. Maioria de sobreviventes morreu, diz ativista, 25 anos após chacina. Agência Brasil. Rio de Janeiro, 2018. Disponível em: $<$ https://agenciabrasil.ebc.com.br/direitos-humanos/noticia/2018-07/naoconsegui-salvar-aquelas-criancas-diz-ativista-25-apos-chacina>. Acesso em: 27 mai. 2021 
OLIVEIRA, Renata H. D.; TURECK, Lucia T. Z. A invisibilidade social e a prática do ato infracional na adolescência: possíveis correlações. Revista Educação e Cultura Contemporânea. PPGE/UNESA. Rio de Janeiro, v. 16, n. 45, 2019.

PAULUZE, Thaiza; NOGUEIRA, Italo. Exército dispara $\mathbf{8 0}$ tiros em carro de família no Rio e mata músico. Folha de S. Paulo, 2019. Disponível em: $<$ https://www1.folha.uol.com.br/cotidiano/2019/04/militares-do-exercitomatam-musico-em-abordagem-na-zona-oeste-do-rio.shtml>. Acesso em: 30 mai. 2021.

PINHO, Débora. A tragédia que expôs o drama do menor abandonado. Consultor Jurídico, 2009. Disponível em: <https://www.conjur.com.br/2009-jul23/imagens-historia-tragedia-expos-drama-menor-abandonado>. Acesso em: 27 mai. 2021.

PERIAGO, Francisco R. A análise discursiva no documentário Ônibus 174. 2016. 232fl. Tese (Doutorado em Letras) - Universidade Presbiteriana Mackenzie - São Paulo, 2016.

Policial confunde ferramenta com arma e mata dois mototaxistas no RJ. G1, 2015. Disponível em: <http://g1.globo.com/bom-dia-brasil/noticia/2015/10/policialconfunde-ferramenta-com-arma-e-mata-dois-mototaxistas-no-rj.html>. Acesso em: 30 mai. 2021.

PREUSSLER, Gustavo S.; CORDAZZO, Karine. A sociedade excludente: exclusão social, criminalidade e diferença na modernidade recente. Direito \& Práxis. Rio de Janeiro: Revan, 2002, 314p.

RODRIGUES, Robson. Os dilemas da pacificação: Notícias de Guerra e Paz em uma “Cidade Maravilhosa". Instituto Igarapé. Rio de Janeiro. vol 7. pags 69/88. Agosto de 2014. Disponível em: <https://igarape.org.br/wpcontent/uploads/2014/07/artigo-8-p5.pdf>. Acesso em: 30 de maio. 2021

SANDEL, Michael J. Justiça: o que é fazer a coisa certa. 31ạ ed. Rio de Janeiro: Civilização brasileira, 2020.

SILVEIRA, Daniel; BOECKEL, Cristina. Chacina da Candelária: sobrevivente ainda tem pesadelos, diz irmã. G1. Rio de Janeiro, 2015. Disponível em: <http://g1.globo.com/rio-de-janeiro/noticia/2015/07/chacina-da-candelariasobrevivente-ainda-tem-pesadelos-diz-irma.html>.Acesso em: 27 mai. 2021.

SILVA, GRANDIN, CAESAR, REIS polícia em 2020; dados disponíveis mostram que 78\% das vítimas são negras. G1, 2021. Disponível em: <https://g1.globo.com/monitor-da-violencia/noticia/2021/04/22/estados-naosabem-raca-de-mais-de-13-dos-mortos-pela-policia-em-2020-dadosdisponiveis-mostram-que-78percent-das-vitimas-sao-negras.ghtml>. Acesso em: 30 mai. 2021 
SOUSA, Alana. Chacina da Candelária: uma noite de brutalidade no Rio de Janeiro. Aventuras na História, 2019. Disponível em: <https://aventurasnahistoria.uol.com.br/noticias/reportagem/historia-chacinada-candelaria-uma-noite-de-brutalidade-no-rio-de-janeiro.phtml>. Acesso em: 27 mai. 2021. 


\title{
CAPITULO III
}

\section{O LICENCIAMENTO AMBIENTAL E O PROJETO DE LEI № 2159/2021 SOB A PERSPECTIVA DO DESENVOLVIMENTO SUSTENTÁVEL}

\author{
DOI: 10.51859/AMPLLA.EDL1037-3
}

\author{
Guilherme Henrique Auerhahn ${ }^{1}$ \\ João Paulo Josviak Dresch ${ }^{2}$
}

\begin{abstract}
${ }^{1}$ Mestrando em Direito Econômico e Desenvolvimento pela Pontifícia Universidade Católica do Paraná (PUCPR) e Especialista em Direito e Processo do Trabalho e Direito Previdenciário pela Escola da Associação dos Magistrados do Trabalho da 9a Região (EMATRA IX). Advogado.

${ }^{2}$ Mestrando em Direito Econômico e Desenvolvimento pela Pontifícia Universidade Católica do Paraná (PUCPR) e Especialista em Compliance e Governança Jurídica pelo Centro Universitário FAE. Advogado.
\end{abstract}

\section{RESUMO}

A institucionalização de uma política de gestão ambiental é fenômeno recente no Brasil, que surgiu a partir de uma mudança global de conscientização ambiental durante a década de 1970, motivando a edição da Lei 6938/1981 através da qual, pela primeira vez em âmbito nacional, houve uma gestão integrada dos recursos naturais expressa por uma Política Nacional do Meio Ambiente (PNMA), que inovou ao prever instrumentos de gestão ambiental como o licenciamento ambiental. Trata-se do instrumento adotado para possibilitar a implementação, construção e operação de empreendimentos que tenham potencial poluidor, garantindo que a necessária proteção ambiental seja observada nesse processo. Esse processo, contudo, sofre diversas críticas quanto ao seu funcionamento, com diversas tentativas de alteração legislativa do processo atual, sendo que o objetivo do presente trabalho é analisar as alterações propostas pelo Projeto de Lei $2159 / 2021$, Projeto de Lei 3.729/2004 e a introdução da Licença por Adesão e Compromisso a fim de responder o questionamento central levantado: se a adoção da LAC é um instrumento capaz de garantir maior eficiência ao processo de licenciamento ambiental ou se tal modificação no sistema pode colocar em risco a proteção ao meio ambiente e o objetivo de se promover o desenvolvimento sustentável previsto na Constituição da República Brasileira. Como objetivo específico, aprofundar-se-á na figura do licenciamento ambiental como instrumento do desenvolvimento sustentável e analisar-se-á as especificidades das alterações propostas. O método utilizado será o dedutivo, lastrado na pesquisa bibliográfica.

Palavras-chave: Desenvolvimento Sustentável. Licenciamento Ambiental. Licença por Adesão e Compromisso. 


\section{INTRODUÇÃO}

A institucionalização de uma política de gestão ambiental é fenômeno recente no Brasil, que surgiu a partir de uma mudança global de conscientização ambiental durante a década de 1970, motivando a edição da Lei 6938/1981 através da qual, pela primeira vez em âmbito nacional, houve uma gestão integrada dos recursos naturais expressa por uma Política Nacional do Meio Ambiente (PNMA).

Além de determinar a criação de relevante órgãos de atuação na esfera ambiental como o Conselho Nacional do Meio Ambiente (CONAMA) e demais órgãos integrantes do Sistema Nacional do Meio Ambiente (SISNAMA), o dispositivo legal também inovou ao prever instrumentos de gestão ambiental que passaram a disciplinar a forma como os recursos ambientais seriam utilizados e apropriados para a atividade produtiva, dentre os quais destaca-se a principal ferramenta de gestão adotada pela PNMA: o licenciamento ambiental. ${ }^{1}$

Trata-se do instrumento adotado para possibilitar a implementação, construção e operação de empreendimentos que tenham potencial poluidor, garantindo que a necessária proteção ambiental seja observada nesse processo, ${ }^{2}$ servindo, assim, como possível ferramenta para equacionar duas grandes preocupações da sociedade, o desenvolvimento econômico e a proteção ambiental, em conformidade com as regras constitucionais que atrelam essas duas preocupações, ou seja, a sustentabilidade aspirada pela combinação dos arts. 170, inciso VI, 186, inciso II, e 225 da Constituição da República. ${ }^{3}$

O Licenciamento ambiental foi instituído, em regra, como um procedimento trifásico, vinculado ao cumprimento das exigências e condicionantes do órgão ambiental competente para se adquirir a licença prévia, licença de instalação e licença de operação

\footnotetext{
${ }^{1}$ FERREIRA, Marcus Bruno Malaquias. SALLES, Alexandre Ottoni Teatini. Política Ambiental Brasileira: Análise Históricoinstitucionalista Das Principais Abordagens Estratégicas. Revista de Economia, v. 43, n. 2 (ano 40), mai./ago. 2016. p. 8.

2 BACELLAR, Regina Maria Bueno. O licenciamento ambiental de empreendimentos de geração de energia como fator determinante para o desenvolvimento sustentável. In: BLANCHET, Luiz Alberto (coord.). Direito da energia: economia, regulação e sustentabilidade. Curitiba: Juruá, 2014. p. 46.

${ }^{3}$ FREITAS, Vladimir Passos de. A desejada e complexa conciliação entre desenvolvimento econômico e proteção do meio ambiente no Brasil. Revista Direito Ambiental e sociedade, v. 4, n. 1, 2014. p. 244.
} 
exigidas. ${ }^{1}$ Esse processo, contudo, sofre diversas críticas quanto ao seu funcionamento, como por exemplo quanto a morosidade do processo, a fragilidade das estruturas institucionais dos órgãos ambientais responsáveis, ausência de recursos adequados para a sua realização e até mesmo quanto a insegurança jurídica dos processos. ${ }^{2}$

É nesse cenário que surgem diversas propostas de alteração do atual sistema de funcionamento do licenciamento ambiental, sob as mais diversas justificativas, sendo que o presente trabalho focar-se-á na proposta de alteração legislativa introduzida pelo Projeto de Lei 3.729/2004, aprovado na Câmera dos Deputados em maio de 2021, passando a tramitar no Senado Federal sob o n.o 2159/2021. Dentre as alterações pretendidas, destaca-se a Licença por Adesão e Compromisso (LAC), que consiste em uma licença ambiental auto declaratória e simplificada que poderia ser adotada em determinados casos previstos por Lei.

A questão que se pretende analisar é se a adoção da LAC é um instrumento capaz de garantir maior eficiência ao processo de licenciamento ambiental ou se tal modificação no sistema pode colocar em risco a proteção ao meio ambiente e o objetivo de se promover o desenvolvimento sustentável previsto na Constituição da República Brasileira.

Para responder o questionamento levantado, o presente trabalho irá iniciar analisando o funcionamento atual no licenciamento ambiental no Brasil e a figura do licenciamento ambiental como instrumento de promoção do desenvolvimento sustentável. Em seguida será abordado sobre a LAC como prevista no PL 3.279/2004 e as dispensas de licença ambiental. Por fim, serão analisados os impactos da proposta de simplificação de desoneração do licenciamento ambiental.

\section{LICENCIAMENTO AMBIENTAL COMO INSTRUMENTO DO DESENVOLVIMENTO SUSTENTÁVEL}

A questão ambiental ganhou enfoque global na década de 1970, em especial com a realização da Conferência de Estocolmo de 1972, sendo que desde que as pautas

\footnotetext{
${ }^{1}$ BACELLAR, Regina Maria Bueno. O licenciamento ambiental de empreendimentos de geração de energia como fator determinante para o desenvolvimento sustentável. In: BLANCHET, Luiz Alberto (coord.). Direito da energia: economia, regulação e sustentabilidade. Curitiba: Juruá, 2014. p. 46.

2 LIMA, Maria Isabel Leite Silva de. REI, Fernando. 40 anos de licenciamento ambiental: um reexame necessário. Rev. Direito Econ. Socioambiental, Curitiba, v. 8, n. 2, maio/ago 2017, p. 378-41.
} 
ambientais ganharam destaque sua análise sempre foi proposta em conjunto com aspectos sociais e econômicos e nunca de maneira isolada ou simplista. ${ }^{1}$

Essa preocupação ecoou na realidade brasileira, sendo que em 1981 a Política Nacional do Meio ambiente foi promulgada com o objetivo expresso de compatibilizar o desenvolvimento econômico e social com a preservação da qualidade do meio ambiente e equilíbrio ecológico e, posteriormente, a própria Constituição da República, através da Emenda Constitucional 42/2003, passou a realizar taxativamente essa mesma vinculação.

A relevância de se destacar essa vinculação se dá justamente para demonstrar que, ao contrário do que se pode aferir pelo senso comum, a preservação ambiental e o desenvolvimento econômico não são antagônicos, mas sim instituições que se completam em prol de um objetivo comum: a qualidade de vida. ${ }^{2}$ A melhora na qualidade de vida humana, como objetivo compartilhado da preservação ambiental e desenvolvimento econômico, ainda que por vieses diferentes, é, portanto, o foco do desenvolvimento sustentável, que integra aspectos ambientais, sociais e econômicos, em especial considerando as limitações ambientais, a fim de permitir a longo prazo o bem-estar da sociedade. ${ }^{3}$

É nesse sentido, considerando certo sacrifício ambiental inevitável que acompanha obras e empreendimentos voltados para o desenvolvimento econômico, como extração de minérios, construção de hidrelétricas e práticas de agricultura, bem como a necessidade de se realizar esses empreendimentos, sob pena de resultar, de forma trágica, em baixos índices de desenvolvimento humano e grandes parcelas da população enfrentando situações de extrema pobreza, em razão da ausência de desenvolvimento econômico, que instrumentos que viabilizem esses empreendimentos sem descuidar da devida proteção ambiental se mostram necessários. ${ }^{4}$

\footnotetext{
${ }^{1}$ FREITAS, Vladimir Passos de. A desejada e complexa conciliação entre desenvolvimento econômico e proteção do meio ambiente no Brasil. Revista Direito Ambiental e sociedade, v. 4, n. 1, 2014. p. 246.

2 Ibidem. p. 247.

3 FEIL, Alexandre André. SCHREIBER, Dusan. Sustentabilidade e desenvolvimento sustentável: desvendando as sobreposições e alcances de seus significados. Cad. EBAPE.BR, v. 14, n , Artigo 7, Rio de Janeiro, Jul./Set. 2017.

${ }^{4}$ FREITAS, Vladimir Passos de. A desejada e complexa conciliação entre desenvolvimento econômico e proteção do meio ambiente no Brasil. Revista Direito Ambiental e sociedade, v. 4, n. 1, 2014. p. 244.
} 
O Licenciamento ambiental foi introduzido pela Política Nacional do Meio Ambiente, em 1981, em seu art. 90, inciso IV, ${ }^{1}$ como um dos principais instrumentos de gestão pública do meio ambiente e até a presente data continua sendo o principal instrumento para compatibilizar a preservação ambiental com avanços exigidos pela economia, inclusive através da utilização de outros instrumentos previstos na PNMA como o estabelecimento de padrões de qualidade e a avaliação de impacto ambiental, que passaram a integrar o licenciamento ambiental como fases de seu procedimento. ${ }^{2}$

Objetiva-se com o licenciamento ambiental promover uma avaliação antecipada dos projetos cuja realização representem potencial degradação ambiental ou poluição, visando que os princípios da prevenção, publicidade, participação sejam cumpridos, em conformidade com a ideia de desenvolvimento sustentável almejada. ${ }^{3}$

Instituído pela PNMA, o licenciamento ambiental como instrumento foi posteriormente regulamentado pelo Decreto n.o $88.351 / 83,4$ substituído posteriormente pelo Decreto $99.274 / 90,{ }^{5}$ que trouxeram a seguinte regra para o licenciamento das atividades:

\begin{abstract}
a construção, instalação, ampliação e funcionamento de estabelecimento de atividades utilizadoras de recursos ambientais, consideradas efetiva ou potencialmente poluidoras, bem assim os empreendimentos capazes, sob qualquer forma, de causar degradação ambiental, dependerão de prévio licenciamento do órgão estadual competente integrante do SISNAMA, sem prejuízo de outras licenças legalmente exigíveis.
\end{abstract}

\footnotetext{
${ }^{1}$ BRASIL. Lei 6.938, de 31 de janeiro de 1981. Brasília. Dispõe sobre a Política Nacional do Meio Ambiente, seus fins e mecanismos de formulação e aplicação, e dá outras providências. Disponível em: <http://www.planalto.gov.br/ccivil_03/leis/l6938.htm> Acesso em: 30 jun. 2021.

2 BACELLAR, Regina Maria Bueno. O licenciamento ambiental de empreendimentos de geração de energia como fator determinante para o desenvolvimento sustentável. In: BLANCHET, Luiz Alberto (coord.). Direito da energia: economia, regulação e sustentabilidade. Curitiba: Juruá, 2014. P. 44.

${ }^{3}$ BACELLAR, Regina Maria Bueno. O licenciamento ambiental de empreendimentos de geração de energia como fator determinante para o desenvolvimento sustentável. In: BLANCHET, Luiz Alberto (coord.). Direito da energia: economia, regulação e sustentabilidade. Curitiba: Juruá, 2014. P. 47.

${ }^{4}$ BRASIL. Decreto n.o 88.351, de 1 ㅇ de junho de 1983. Regulamenta a Lei no 6.938, de 31 de agosto de 1981, e a Lei no 6.902, de 27 de abril de 1981, que dispõem, respectivamente, sobre a Política Nacional do Meio Ambiente e sobre a criação de Estações Ecológicas e Áreas de Proteção Ambiental, e dá outras providências. Disponível em: http://www.planalto.gov.br/ccivil_03/decreto/1980-1989/D88351.htm. Acesso em: 30 jun. 2021.

${ }^{5}$ BRASIL. Decreto n. ㅇ 99.274, de 06 de junho de 1990. Regulamenta a Lei no 6.902, de 27 de abril de 1981, e a Lei no 6.938, de 31 de agosto de 1981, que dispõem, respectivamente sobre a criação de Estações Ecológicas e Áreas de Proteção Ambiental e sobre a Política Nacional do Meio Ambiente, e dá outras providências. Disponível em: http://www.planalto.gov.br/ccivil_03/decreto/antigos/d99274.htm. Acesso em: 30 jun. 2021.
} 
Determinou-se como regra o licenciamento ambiental trifásico, por meio do qual três licenças ambientais distintas são emitidas pelo poder público durante um único processo de licenciamento, para fins de cumprir o objetivo estabelecido pela norma. ${ }^{1}$

De acordo com o art. 19 do Decreto 99.274/90, emite-se primeiramente a Licença Prévia, durante a fase preliminar do planejamento da atividade com possíveis impactos ambientais, contendo os requisitos básicos a serem atendidos e atestando pela viabilidade ambiental do projeto a ser implementado. Atestada tal viabilidade, procede-se para a emissão da licença de instalação, por meio da qual o empreendedor fica autorizada a iniciar a construção do seu empreendimento. Cumpridas as condicionantes e exigências, realizadas as vistorias pelo órgão competente, a próxima etapa no processo de licenciamento é a licença de operação, por meio da qual autorizase o empreendedor a iniciar a operação comercial do empreendimento construído.

Os referidos Decretos instituíram o Conselho Nacional do Meio ambiente (CONAMA) como o órgão competente para fixar os critérios básicos segundo os quais serão exigidos estudos de impacto ambiental (EIA) no processo de licenciamento, realizado por técnicos habilitados, à conta do proponente do projeto, a fim de se constituir Relatório de Impacto Ambiental (RIMA) contendo no mínimo o diagnóstico ambiental da área do projeto, descrição do projeto e alternativas e a identificação, análise e previsão dos impactos significativos do projeto, sejam eles positivos ou negativos.

A partir dessa sua atribuição, o CONAMA editou a resolução número 01/1986, ${ }^{2}$ documento que estabelece as definições, responsabilidades e diretrizes do EIA e seu RIMA, bem como a resolução $237 / 1997^{3}$ que dispõe sobre as definições de estudos ambientais e diretrizes para a implementação de avaliação de impacto ambiental.

Em linhas gerais o EIA e o RIMA são obrigatórios no processo de licenciamento ambiental sempre as normas aplicáveis assim exigirem ou nos casos de significativa degradação ambiental, sendo que nos casos de menor impacto, quando assim for

\footnotetext{
${ }^{1}$ BACELLAR, Regina Maria Bueno. O licenciamento ambiental de empreendimentos de geração de energia como fator determinante para o desenvolvimento sustentável. In: BLANCHET, Luiz Alberto (coord.). Direito da energia: economia, regulação e sustentabilidade. Curitiba: Juruá, 2014. P. 48.

2 CONAMA. Resolução CONAMA n. 001, de 23 de janeiro de 1986. Disponível em: http://www2.mma.gov.br/port/conama/res/res86/res0186.html. Acesso em: 28 jun. 2021.

3 CONAMA. Resolução CONAMA n.o 237, de 19 de dezembro de 1997. Disponível em: http://www2.mma.gov.br/port/conama/res/res97/res23797.html. Acesso em: 28 jun. 2021.
} 
autorizado pela Autoridade competente, esse estudo pode ser substituído por estudos simplificados. ${ }^{1}$

Esse sistema foi confirmado pela constituição da República de 1988, que em seu art. $255, \S 1$, inciso IV confirmou que para assegurar a efetividade do direito ao meio ambiente ecologicamente equilibrado para as presentes e futuras gerações, o Poder Público deve exigir para a instalação de atividade ou obra com potencial poluidor ou passível de causar degradação ambiental, deve-se exigir estudo prévio de impacto ambiental e garantir publicidade a esse estudo, uma vez que, de acordo com o referido artigo, meio ambiente é bem de uso comum do povo.

O licenciamento ambiental não é um ato isolado, mas sim um processo complexo realizado em regra seguindo essa lógica trifásica e com diversas etapas que são estão resumidamente previstas no art. 10 da resolução CONAMA n.o 237/97 no seguinte sentido:

Art. 10 - O procedimento de licenciamento ambiental obedecerá às seguintes etapas:

I - Definição pelo órgão ambiental competente, com a participação do empreendedor, dos documentos, projetos e estudos ambientais, necessários ao início do processo de licenciamento correspondente à licença a ser requerida;

II - Requerimento da licença ambiental pelo empreendedor, acompanhado dos documentos, projetos e estudos ambientais pertinentes, dando-se a devida publicidade;

III - Análise pelo órgão ambiental competente, integrante do SISNAMA, dos documentos, projetos e estudos ambientais apresentados e a realização de vistorias técnicas, quando necessárias;

IV - Solicitação de esclarecimentos e complementações pelo órgão ambiental competente, integrante do SISNAMA, uma única vez, em decorrência da análise dos documentos, projetos e estudos ambientais apresentados, quando couber, podendo haver a reiteração da mesma solicitação caso os esclarecimentos e complementações não tenham sido satisfatórios;

V - Audiência pública, quando couber, de acordo com a regulamentação pertinente;

VI - Solicitação de esclarecimentos e complementações pelo órgão ambiental competente, decorrentes de audiências públicas, quando couber, podendo haver reiteração da solicitação quando os esclarecimentos e complementações não tenham sido satisfatórios;

VII - Emissão de parecer técnico conclusivo e, quando couber, parecer jurídico;

${ }^{1}$ LIMA, Maria Isabel Leite Silva de. REI, Fernando. 40 anos de licenciamento ambiental: um reexame necessário. Rev. Direito Econ. Socioambiental, Curitiba, v. 8, n. 2, maio/ago 2017, p. 388. 
VIII - Deferimento ou indeferimento do pedido de licença, dando-se a devida publicidade.

Todas as normas supracitadas são estabelecidas em âmbito nacional pela competência da União para editar normas gerais para disciplinar normas ambientais no país, uniformização necessária para se estabelecer balizas gerais e garantir segurança jurídica ao processo de licenciamento, mas os Estados Municípios e Distrito Federal também possuem competência para legislar sobre questões ambientais.

A Lei Complementar $140 / 2011^{1}$ fixa as regras de cooperação entre os entes federativos na gestão e ambiental e, especificamente sobre o licenciamento ambiental, determina que é competência da União promover o licenciamento ambiental de empreendimentos transfronteiriços, no mar territorial, em terras indígenas, em área de preservação ambiental e demais casos nos quais a alta possibilidade de impacto ambiental justifica a interferência da União, através da Autoridade designada pela União para exercer essa função: o IBAMA. ${ }^{2}$

Aos Municípios compete o licenciamento de atividades com condão de impacto ambiental local ou localizados em unidades de conservação instituídas pelos municípios. Aos Estados, por sua vez, compete o licenciamento ambiental de forma residual, ou seja, aquilo que não for objeto de legislação pela União e Municípios. ${ }^{3}$

Como se vê, o licenciamento ambiental foi instituído para funcionar como um instrumento multifuncional, objetivando garantir fundamento técnico na tomada de decisão pública que envolva empreendimentos que afetem os recursos ambientais, assegurar que os projetos submetidos à aprovação do órgão competente contenham medidas para evitar ou minimizar os impactos negativos inerentes ao empreendimento e definir as medidas necessárias para que o empreendimento funcione com o menor impacto adverso possível sem que viabilidade econômica seja comprometida. ${ }^{4}$

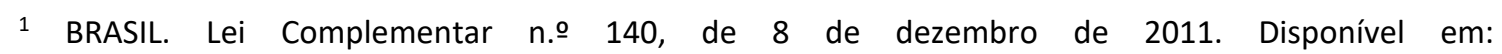
http://www.planalto.gov.br/ccivil_03/leis/lcp/lcp140.htm. Acesso em 01 jul. 2021.

2 SAMPAIO, Rômulo Silveira da Rocha. LAMARE, Julia Macedo de. KLOSS, Viviane Damato Otto. Regulação ambiental e a tragédia dos antibens comuns: análise da eficiência e efetividade aplicáveis ao regime de competência em matéria de licenciamento ambiental. Revista Direito Ambiental e sociedade, v. 6, n. 1, 2016. p. 192.

3 Ibidem. p. 193.

${ }^{4}$ SÁNCHEZ, Luis E. Para que serve (ou deveria servir) o licenciamento ambiental? Jornal da USP. Disponível em: https://jornal.usp.br/?p=327204. Acesso em 01 jul. 2021. 
Não se trata de medida que busca inviabilizar a implementação do empreendimento pretendido, mas sim de garantir que esse processo de implementação ocorre de maneira compatível com as regras do jogo determinadas pelas instituições brasileiras no âmbito de gestão ambiental. ${ }^{1}$

Ocorre que na prática, o processo ambiental enfrenta alguns problemas na sua operacionalização que o tornam alvo de diversas críticas e diversas tentativas de alteração legislativa no decorrer dos anos. Dentre as críticas que o instituto sofre destaca-se a alegada morosidade na tramitação do procedimento de licenciamento ambiental, que pode ser atribuída a diversos fatores como a atuação de múltiplos órgãos, alegado excesso de intervenção do judiciário e paralização do licenciamento, falta de técnicos para tratar das questões ambientais e a própria complexidade do procedimento instituído por Lei. ${ }^{2}$

É nesse cenário que diversas tentativas de modificação do sistema atuam ganharam espaço no debate legislativo, sendo que o presente trabalho analisará especificamente a proposta de alteração legislativa introduzida pelo Projeto de Lei 3.729/2004, que pretende instituir em âmbito nacional a figura do licenciamento ambiental por adesão. Verificar-se-á se essa proposta de fato pode garantir maior eficiência ao processo de licenciamento sem que os objetivos pelos quais o licenciamento é atualmente exigido deixem de ser observados.

\section{A LICENÇA POR ADESÃO E COMPROMISSO INSERIDA NO PROJETO DE LEI 3.729/2004 E AS DISPENSAS DE LICENÇA AMBIENTAL: 0 FIM DO LICENCIAMENTO AMBIENTAL?}

O projeto de lei (P.L.) no 3.729/2004 teve sua aprovação pela câmara de deputados e sua respectiva remessa para o Senado Federal em maio/2021, tomando como nova identificação no Senado Federal o P.L. no 2159/2021. O texto do projeto de

\footnotetext{
${ }^{1}$ LIMA, Maria Isabel Leite Silva de. REI, Fernando. 40 anos de licenciamento ambiental: um reexame necessário. Rev. Direito Econ. Socioambiental, Curitiba, v. 8, n. 2, maio/ago 2017, p. 388.

${ }^{2}$ LIMA, Maria Isabel Leite Silva de; REI, Fernando. 40 anos de licenciamento ambiental: um reexame necessário. Revista de Direito Econômico e Socioambiental, Curitiba, v. 8, n. 2, p. 378-410, maio/ago. 2017. p. 394.
} 
lei foi alterado por diversas vezes na Câmara dos Deputados, sendo o texto final de remessa ao Senado Federal bastante diferente de seu texto original.

Dentre os diversos objetivos do projeto de lei em comento, visa dispor sobre o licenciamento ambiental, inserindo hipótese para estabelecimento da Licença por Adesão e Compromisso (LAC), caracterizada por ser uma licença autodeclaratória simplificada, em que, caso cumpridos determinados requisitos, será concedida a licença ambiental ao requerente sem prévia inspeção e demais formalidades da licença ordinária.

De igual forma, tramita, por iniciativa da Associação Brasileira de Entidades de Meio Ambiente (ABEMA), projeto que visa a atualização dos procedimentos de licenciamento ambiental, estabelecendo novos modelos: licenciamento ambiental trifásico, licenciamento unificado, licenciamento ambiental por registro e licenciamento ambiental por adesão e compromisso. ${ }^{1}$

A possibilidade de se estabelecer uma licença autodeclaratória não é uma inovação. Essa mesma modalidade pode ser observada, como exemplo, na resolução CEMA no 107/2020, ${ }^{2}$ do estado do Paraná, que autoriza a possibilidade de estabelecimento das LACs para atividades e empreendimentos de pequeno potencial de impacto ambiental e na resolução CONSEMA no 98, do estado de Santa Catarina, que define em seu artigo 2ㅇ, XXVIII, o conceito de $\mathrm{LAC}^{3}$ dispondo em seu anexo "VI" as atividades passíveis de serem submetidas ao Licenciamento por Adesão e Compromisso.

${ }^{1}$ LIMA, Maria Isabel Leite Silva de; REI, Fernando. 40 anos de licenciamento ambiental: um reexame necessário. Revista de Direito Econômico e Socioambiental, Curitiba, v. 8, n. 2, p. 378-410, maio/ago. 2017. p. 400.

${ }^{2}$ Art. 3.o O órgão ambiental competente, no exercício de sua competência de controle ambiental, expedirá os seguintes atos administrativos, referentes ao licenciamento ambiental:

III- Licença Ambiental por Adesão e Compromisso - LAC: autoriza a instalação e a operação de atividade ou empreendimento, de pequeno potencial de impacto ambiental, mediante declaração de adesão e compromisso do empreendedor aos critérios, pré-condições, requisitos e condicionantes ambientais estabelecidos pela autoridade licenciadora, desde que se conheçam previamente os impactos ambientais da atividade ou empreendimento, as características ambientais da área de implantação e as condições de sua instalação e operação. In. PARANÁ. Resolução CEMA no 107. D. O. 17 set. 2020.

${ }^{3}$ Art. 2ㅇ Para fins desta resolução adotam-se as seguintes definições:

(...)

XXVIII - Licença de Adesão ou Compromisso (LAC): documento de licenciamento, preferencialmente obtido por meio eletrônico, em uma única etapa, por meio de declaração de adesão e compromisso do empreendedor aos critérios e pré-condições estabelecidas pelo órgão ambiental licenciador para a instalação e operação do empreendimento ou atividade (...). In SANTA CATARINA, Resolução CONSEMA № 98, de 5 mai. 2017. 
Por sua vez, o artigo 21 , do projeto de lei $3.729 / 2004$, referente ao texto do projeto que obteve remessa ao Senado Federal trata do Licenciamento por Adesão e Compromisso, restando assim estabelecido:

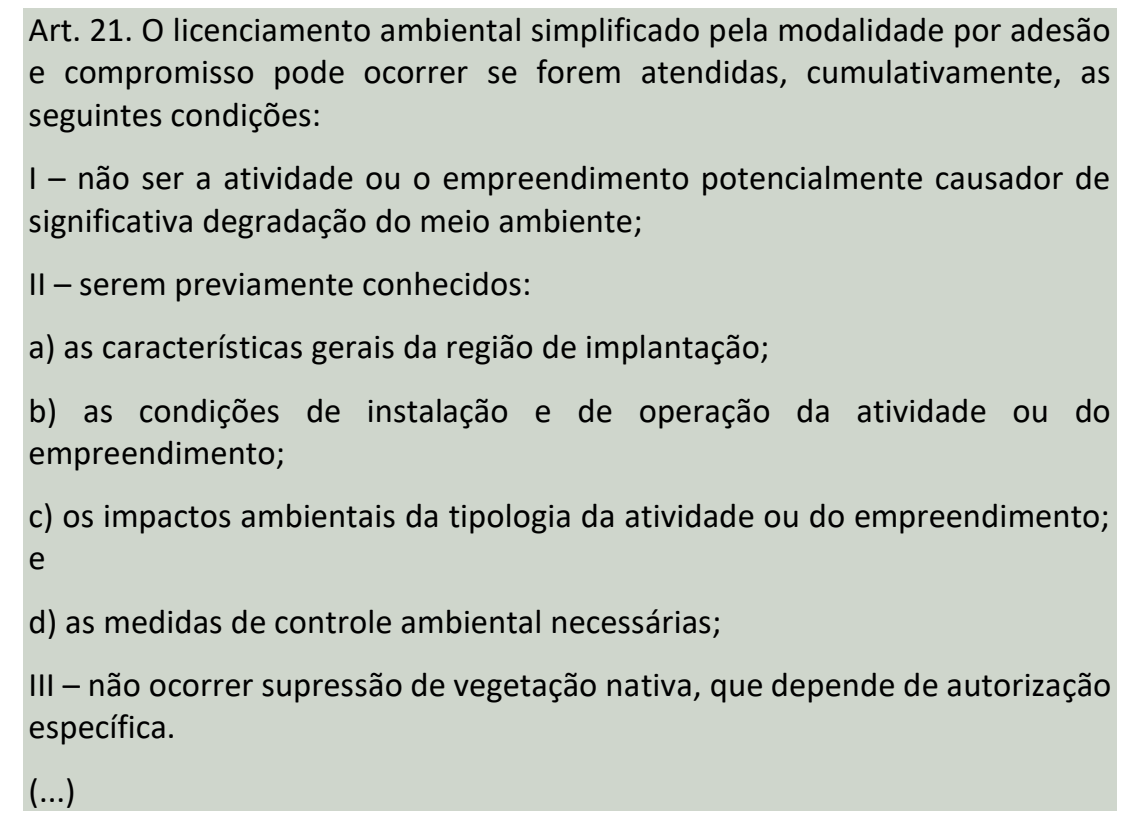

O licenciamento ambiental por adesão e compromisso parte de uma iniciativa de simplificação do licenciamento ambiental, assim, estabelecendo o projeto de lei que, caso cumprido cumulativamente as condições exigidas pelo P.L. 3.729/2004, é possível que se conceda a LAC à atividade ou empreendimento. As atividades e empreendimentos passíveis dessa modalidade de licenciamento serão aqueles definidos em ato específico pelo ato federativo competente, seguindo a regra de competência da Lei Complementar no 140/2011. ${ }^{1}$

A autoridade licenciadora, dentro de sua competência, deverá estabelecer previamente quais as condicionantes da LAC que o empreendedor deverá cumprir para se habilitar ao recebimento da referida licença. ${ }^{2}$

A autoridade licenciadora deverá conferir e analisar as informações prestadas pelo empreendedor no Relatório de Caracterização do Empreendimento (RCE), por

1 10 São considerados atividades e empreendimentos passíveis de licenciamento ambiental pelo procedimento por adesão e compromisso aqueles definidos em ato específico do ente federativo competente, nos termos da Lei Complementar no 140, de 8 de dezembro de 2011. In. BRASIL. Projeto de lei no 3.729/2004. Dispõe sobre o licenciamento ambiental, regulamenta o inciso IV do $\S 10$ do art. 225 da Constituição Federal, e dá outras providências. Disponível em: https://www.camara.leg.br/proposicoesWeb/fichadetramitacao?idProposicao=257161. Acesso em 25 jun. 2021.

$2 \S 2$ o A autoridade licenciadora deve estabelecer previamente as condicionantes ambientais da LAC que o empreendedor deverá cumprir. In. Ibidem. 
amostragem, incluída a realização de vistorias, por amostragem, encartando o resultado nos subsistemas do respectivo órgão licenciador. ${ }^{1} \mathrm{O}$ resultado das vistorias previstas pode orientar a revisão ou manutenção do licenciamento ambiental pela via da $\mathrm{LAC}^{2} \mathrm{Ao}$ final, trata o seu parágrafo 5o sobre prazos de validade e procedimentos de renovação da LAC. ${ }^{3}$

As disposições demonstram que a LAC visa, em atividades e empreendimentos de suposto menor potencial lesivo, realizar um licenciamento ambiental simplificado, reduzindo as suas formalidades e acelerando o processo para sua obtenção e respectiva regularização do empreendimento.

Ainda no P.L. 3.729/2004, em seu artigo 8o, o projeto de lei dispõe sobre a dispensa de licenciamento ambiental um rol de atividades tidas como de menor potencial lesivo, porém, não as eximindo de demais autorizações como, por exemplo, autorização de supressão nativa.

No artigo 9으, do referido projeto de lei, cumpridos determinados requisitos dispostos no artigo, como comprovação de regularização do imóvel, registro no Cadastro Ambiental Rural, adesão ao Programa de Regularização Ambiental e outros, exime as seguintes atividades de regularização ambiental:

Art. 9o As seguintes atividades e empreendimentos não são sujeitos a
licenciamento ambiental, quando atendido o previsto neste artigo:
I - cultivo de espécies de interesse agrícola, temporárias, semiperenes e
perenes;
II - pecuária extensiva e semi-intensiva;
III - pecuária intensiva de pequeno porte, nos termos do art. 4o, $\S 1$;
IV - pesquisa de natureza agropecuária, que não implique risco biológico,
desde que haja autorização prévia dos órgãos competentes e ressalvado o
disposto na Lei no 11.105 , de 24 de março de 2005 ;
(...) ${ }^{4}$.

${ }^{1} \S$ 3ㅇ As informações apresentadas pelo empreendedor no RCE devem ser conferidas e analisadas pela autoridade licenciadora por amostragem, incluída a realização de vistorias, estas também por amostragem, devendo disponibilizar os resultados no subsistema de informações previsto no art. 31 desta Lei. In: BRASIL. Projeto de lei no 3.729/2004. Dispõe sobre o licenciamento ambiental, regulamenta o inciso IV do $\S 1$ o do art. 225 da Constituição Federal, e dá outras providências. Disponível em: https://www.camara.leg.br/proposicoesWeb/fichadetramitacao?idProposicao=257161. Acesso em 25 jun. 2021.

$2 \S 4$ o O resultado das vistorias previstas no $§ 3$ 얼 deste artigo pode orientar a manutenção ou a revisão dos atos sobre as atividades e os empreendimentos passíveis de licenciamento ambiental pelo procedimento por adesão e compromisso. In: Ibidem.

${ }^{3} \S 5$ ㅇ Aos prazos de validade e procedimentos de renovação da LAC aplicam-se, no que couber, os arts. 6o, 7ㅇ, 14 e 15. In: Ibidem.

${ }^{4}$ Ibidem. 
Como observado, o projeto de lei altera boa parte da dinâmica de licenciamento ambiental, insere novas modalidades simplificadas de licenciamento, algumas hipóteses de isenção, porém, não há como afirmar que é o "fim do licenciamento ambiental", mas sim, de uma alteração da matriz constituída, que sempre visou o licenciamento ambiental como uma forma efetiva para se prever e evitar a degradação ambiental.

Com as alterações, a partir da legislação, assume-se que um rol de atividades, cumpridos os requisitos da LAC e da isenção, não tem caráter de degradação tão latente quanto outras atividades, o que acaba possibilitando a isenção e/ou simplificação do processo de licenciamento.

A Política Nacional do Meio Ambiente, visando a compatibilização do desenvolvimento socioeconômico com a conservação do meio ambiente, elenca a Avaliação de Impacto Ambiental (AIA) e o licenciamento ambiental como sendo instrumentos da política ambiental, tendo sido criados para que se alcance os seus objetivos $^{1}$.

O desvirtuamento do licenciamento ambiental não indica que haverá a sua extinção, mas que haverá uma nova forma de controle das atividades licenciadas e não licenciadas. No exemplo das LACs, há a possibilidade que se façam, além das conferências documentais dos procedimentos, inspeções nos empreendimentos cujas licenças são constituídas. A problemática se dá quando analisado o real objetivo da criação das licenças ambientais.

As licenças ambientais são instrumentos da gestão pública destinados a "subordinar as atividades capazes de alterar substancialmente os ecossistemas a um regime de controle apriorístico, configurando a licença, destarte, um assentimento da autoridade competente", ${ }^{2}$ visando verificar o potencial ofensivo da atividade, assim, sendo pendente a apreciação ou não da referida licença, inclusive, sendo possível a

\footnotetext{
${ }^{1}$ LOPES, Maíria de Sousa; BRITO, Daguinete Maria Chaves. Trajetória histórica do licenciamento ambiental da hidrelétrica de Santo Antônio do Jari/Amapá-Brasil. Revista Internacional de Direito Ambiental e Políticas Públicas. n. 10, p. 141-152, 2018. p. 142.

${ }^{2}$ MARIA, Dioclides José; GOMES, Magno Federici. Da (im)possibilidade do ajuizamento da ação direta interventiva para assegurar a autonomia municipal para legislar sobre licenciamento ambiental de impacto local. Rev. Direito Econ. Socioambiental, Curitiba, v. 8, n. 1, p. 303-330, jan./abr. 2017. p. 313.
} 
mitigação e/ou compensação dos impactos criados pelo empreendimento, à luz do artigo $225, \S 1$ o, IV , da Constituição Federal. ${ }^{1}$

A questão, de fato, a ser abordada não é sobre o fim do processo de licenciamento ambiental, mas sim, quais os impactos que a alteração que a simplificação e exoneração do licenciamento ambiental trarão às atividades, tendo como norte o objetivo do próprio licenciamento ambiental, que é a prevenção de possíveis danos causados por atividades potencialmente degradadoras ao meio ambiente.

\section{IMPACTOS DA PROPOSTA DE SIMPLIFICAÇÃO E DESONERAÇÃO DO LICENCIAMENTO AMBIENTAL}

A simplificação e desoneração trazidas pelo projeto de lei no $3.729 / 2004$, em caso de aprovação e sanção do projeto, trarão diversos impactos na consecução do artigo 225, da Constituição Federal, tendo como prisma de análise o princípio da prevenção e precaução do direito ambiental.

O princípio da prevenção e precaução, em matéria ambiental, tem como finalidade assegurar, neste caso, nas esferas municipais, estaduais e federal, a preservação dos bens ambientais de atividades danosas, mesmo que implique em obstáculo da atividade caso não seja possível a sua mitigação em níveis aceitáveis de risco ambiental. ${ }^{2}$

Quando o projeto de lei assume a postura de indicar quais atividades estão sujeitas ou não ao licenciamento, seja ainda na condição simplificada, assume o risco de identificar previamente quais atividades, por sua natureza, não implicam a risco ambiental ou que são de menor potencial lesivo, mesmo que ausente a respectiva AIA

\footnotetext{
${ }^{1}$ Art. 225. Todos têm direito ao meio ambiente ecologicamente equilibrado, bem de uso comum do povo e essencial à sadia qualidade de vida, impondo-se ao Poder Público e à coletividade o dever de defendêlo e preservá- lo para as presentes e futuras gerações.

$\S 1$ o Para assegurar a efetividade desse direito, incumbe ao Poder Público:

(...)

IV - exigir, na forma da lei, para instalação de obra ou atividade potencialmente causadora de significativa degradação do meio ambiente, estudo prévio de impacto ambiental, a que se dará publicidade; In. BRASIL. Constituição da República Federativa do Brasil (1988). Disponível em:<http://www.planalto.gov.br/ccivil_03/constituicao/constituicaocompilado.htm>. Acesso em: 27 jun. 2021.

${ }^{2}$ MOREIRA, Nelson Camatta. et al. Judicialização da política de proteção ambiental na expansão da exploração do petróleo no Espírito Santo. Revista de direito econômico e socioambiental, Curitiba, v. 3, n. 1, p. 79-105, jan/jun, 2012. p. 95 e 96.
} 
e demais procedimentos presentes no licenciamento ambiental, levando à zona da especulação, afastando-se do caráter de precaução e prevenção do direito ambiental.

Na hipótese de realização do licenciamento ambiental da forma ordinária, assim como indicado na primeira seção, o objetivo da análise prévia se baseia em prevenir que a degradação ocorra. No caso da licença por adesão e compromisso, a prevenção é existente na análise documental, porém, no caso de licenciar a prestação de serviços pelo empreendimento a partir da concepção de ser uma atividade de menor risco, passa-se a responsabilidade para o período pós licenciamento, ou seja, a observação da condição após a sua ocorrência.

Nos casos de exoneração de licenciamento ambiental, a possível degradação ambiental só é enfrentada após já ocorrido o risco da atividade, ou seja, não havendo cautelas face a um bem difuso constitucionalmente garantido.

Ao assumir a postura de simplificar e exonerar do licenciamento ambiental de determinadas atividades, o caráter de preservação ao meio ambiente demonstra-se relativizado, assim, entrando em descompasso com a própria Constituição Federal, que prevê o direito ao meio ambiente como um direito/dever comum de todos, impondo responsabilidades ao Estado e à sociedade, para viabilizar a consecução desse direito fundamental. ${ }^{1}$

A observação dos riscos ambientais de forma preventiva assim como observada nas licenças ambientais ordinárias permitem a observação do princípio da responsabilidade intergeracional ambiental, permitindo a preservação do meio ambiente para as gerações futuras. Em que pese não se observe o fim do licenciamento ambiental com o projeto de lei 3.729/04, percebe-se que há um conflito com a Constituição Federal, podendo ser solucionado de duas maneiras.

Uma primeira maneira de solução desse descompasso é, ainda no Senado Federal, que se adeque a lei com os ditames constitucionais em matéria ambiental, assim, respeitando os direitos e princípios com a possível sanção da lei. Uma segunda forma de solução ao problema é o enfrentamento das passíveis inconstitucionalidades por parte do judiciário, o que, dado o momento de construção de uma nova lei que visa

\footnotetext{
${ }^{1}$ MARVIN, Eriberto Francisco Bevilaqua; MASCARENHAS, Giovanni Martins de Araújo. Direito ao meio ambiente e mudanças climáticas: o constitucionalismo brasileiro e o acordo de Paris. Rev. Direito Econ. Socioambiental, Curitiba, v. 11, n. 2, p. 254-287, maio/ago. 2020. p. 280.
} 
desburocratizar e agilizar o licenciamento ambiental, deixar que seja solucionada as inconstitucionalidades seria um contrassenso, apenas tratando de forma mais morosa o problema que já se mostra evidente na proposta de legislação.

Ressalta-se, também, que ao alterar a sistemática atual do processo de licenciamento ambiental, o Projeto de Lei não enfrenta os desafios que são comuns para todas as modalidades de licença ambiental e que persistirão ainda que projeto seja aprovado. As novas modalidades trazidas pelo Projeto de Lei não dispensam a atuação dos órgãos ambientais, apenas alteram a forma como essa atuação é realizada e, inclusive, o próprio PL 3279/2004, em seu art. 21, § 2으, determina que a autoridade licenciadora deve estabelecer previamente as condicionantes ambientais da LAC que o empreendedor deve cumprir.

Nesse sentido, ao depender da atuação dos órgãos ambientais e regulamentação infra legal por esses órgãos, a aplicabilidade da LAC encontra empecilhos no esvaziamento e enfraquecimento desses órgãos que notoriamente estão com a sua atuação prejudicada. Não há como se garantir um procedimento que garanta de forma eficaz a preservação ambiental em empreendimentos potencialmente poluidores, sem que seja garantido o bom funcionamento dos órgãos responsáveis pelas questões envoltas ao licenciamento, de modo que, nesse ponto, a LAC encontra as mesmas dificuldades das modalidades de licença atualmente existentes. ${ }^{1}$

\section{CONSIDERAÇÕES FINAIS}

O licenciamento ambiental é um meio pelo qual se permite alcançar o desenvolvimento econômico sem que seja comprometido o meio ambiente, assim, possibilitando o desenvolvimento sustentável, visando a proteção do meio ambiente para a presente e para as próximas gerações.

Com a redação do projeto de lei no $2159 / 2021$ do Senado Federal recebido da Câmara dos Deputados, dentre as várias alterações em matéria de direito ambiental, busca a desburocratização do licenciamento ambiental, a partir da simplificação, pelas LACs e pelas atividades que encontraram a isenção do licenciamento ambiental.

\footnotetext{
${ }^{1}$ SÁNCHEZ, Luis E. Para que serve (ou deveria servir) o licenciamento ambiental? Jornal da USP. Disponível em: https://jornal.usp.br/?p=327204. Acesso em 01 jul. 2021.
} 
A via da simplificação e isenção do processo de licenciamento ambiental não indica o fim do licenciamento ambiental, porém, altera o processo lógico de preservação do licenciamento ambiental, que parte, a partir de seu procedimento ordinário, de prevenir eventuais danos ambientais pelos estudos prévios dos impactos ambientais e demais procedimentos acautelatórios.

Na sua falta ou simplificação, passa o trabalho dos órgãos ambientais em fiscalizar os empreendimentos que obtém essa simplificação e isenção, enfrentando a questão de forma de contingência, ou seja, não mais de forma a de prevenção, mas sim, de forma posterior ao evento.

Sob a luz do desenvolvimento sustentável em busca da solidariedade intergeracional e do cumprimento ao texto constitucional, em especial, ao seu artigo no 225, cumpre ao Senado Federal, na análise do projeto recebido, observar as inconstitucionalidades do projeto, tendo como norte os direitos e garantias constitucionais. Não o fazendo, a solução em prol da proteção ao meio ambiente partirá de provocações de inconstitucionalidades da lei, quando e se sancionada, a partir do judiciário. Eventual manutenção do projeto apresentado demonstrará a quebra do paradigma da prevenção, rumando para a proteção do meio ambiente a partir de inspeções posteriores aos eventos e operações potencialmente danosas.

\section{REFERÊNCIAS}

BACELLAR, Regina Maria Bueno. O licenciamento ambiental de empreendimentos de geração de energia como fator determinante para o desenvolvimento sustentável. In: BLANCHET, Luiz Alberto (coord.). Direito da energia: economia, regulação e sustentabilidade. Curitiba: Juruá, 2014. 120p.

BRASIL. Constituição da República Federativa do Brasil (1988). Disponível em:<http://www.planalto.gov.br/ccivil_03/constituicao/constituicaocompilado. htm>. Acesso em: 27 jun. 2021.

BRASIL. Decreto n. ㅇ 99.274, de 06 de junho de 1990. Regulamenta a Lei no 6.902, de 27 de abril de 1981, e a Lei no 6.938, de 31 de agosto de 1981, que dispõem, respectivamente sobre a criação de Estações Ecológicas e Áreas de Proteção Ambiental e sobre a Política Nacional do Meio Ambiente, e dá outras providências. Disponível em: http://www.planalto.gov.br/ccivil_03/decreto/antigos/d99274.htm. Acesso em: 30 jun. 2021. 
BRASIL. Decreto n.o 88.351, de 1 ㅇ de junho de 1983. Regulamenta a Lei $n=6.938$, de 31 de agosto de 1981, e a Lei no 6.902, de 27 de abril de 1981, que dispõem, respectivamente, sobre a Política Nacional do Meio Ambiente e sobre a criação de Estações Ecológicas e Áreas de Proteção Ambiental, e dá outras providências. Disponível em: http://www.planalto.gov.br/ccivil_03/decreto/19801989/D88351.htm. Acesso em: 30 jun. 2021.

BRASIL. Lei 6.938, de 31 de janeiro de 1981. Brasília. Dispõe sobre a Política Nacional do Meio Ambiente, seus fins e mecanismos de formulação e aplicação, e dá outras providências.

Disponível

em: <http://www.planalto.gov.br/ccivil_03/leis/l6938.htm> Acesso em: 30 jun. 2021.

BRASIL. Lei Complementar n. 140, de 8 de dezembro de 2011. Disponível em: http://www.planalto.gov.br/ccivil_03/leis/lcp/lcp140.htm. Acesso em 01 jul. 2021.

BRASIL. Projeto de lei $\mathbf{n} 0$ 3.729/2004. Dispõe sobre o licenciamento ambiental, regulamenta o inciso IV do $\S 1$ o do art. 225 da Constituição Federal, e dá outras providências. Disponível em: https://www.camara.leg.br/proposicoesWeb/fichadetramitacao?idProposicao= 257161. Acesso em 25 jun. 2021.

CONAMA. Resolução CONAMA n. 001, de 23 de janeiro de 1986. Disponível em: http://www2.mma.gov.br/port/conama/res/res86/res0186.html. Acesso em: 28 jun. 2021.

CONAMA. Resolução CONAMA n.o 237, de 19 de dezembro de 1997. Disponível em: http://www2.mma.gov.br/port/conama/res/res97/res23797.html. Acesso em: 28 jun. 2021.

FEIL, Alexandre André. SCHREIBER, Dusan. Sustentabilidade e desenvolvimento sustentável: desvendando as sobreposições e alcances de seus significados. Cad. EBAPE.BR, v. 14, no 3, Artigo 7, Rio de Janeiro, Jul./Set. 2017.

FERREIRA, Marcus Bruno Malaquias. SALLES, Alexandre Ottoni Teatini. Política Ambiental Brasileira: Análise Históricoinstitucionalista Das Principais Abordagens Estratégicas. Revista de Economia, v. 43, n. 2 (ano 40), mai./ago. 2016.

FREITAS, Vladimir Passos de. A desejada e complexa conciliação entre desenvolvimento econômico e proteção do meio ambiente no Brasil. Revista Direito Ambiental e sociedade, v. 4, n. 1, 2014 (p. 235-263)

LIMA, Maria Isabel Leite Silva de. REI, Fernando. 40 anos de licenciamento ambiental: um reexame necessário. Rev. Direito Econ. Socioambiental, Curitiba, v. 8, n. 2, maio/ago 2017, p. 378-41. 
LOPES, Maíria de Sousa; BRITO, Daguinete Maria Chaves. Trajetória histórica do licenciamento ambiental da hidrelétrica de Santo Antônio do Jari/Amapá-Brasil. Revista Internacional de Direito Ambiental e Políticas Públicas. n. 10, p. 141152, 2018. p. 142.

MARIA, Dioclides José; GOMES, Magno Federici. Da (im)possibilidade do ajuizamento da ação direta interventiva para assegurar a autonomia municipal para legislar sobre licenciamento ambiental de impacto local. Rev. Direito Econ. Socioambiental, Curitiba, v. 8, n. 1, p. 303-330, jan./abr. 2017.

MARVIN, Eriberto Francisco Bevilaqua; MASCARENHAS, Giovanni Martins de Araújo. Direito ao meio ambiente e mudanças climáticas: o constitucionalismo brasileiro e o acordo de Paris. Rev. Direito Econ. Socioambiental, Curitiba, v. 11, n. 2, p. 254-287, maio/ago. 2020.

MOREIRA, Nelson Camatta. et al. Judicialização da política de proteção ambiental na expansão da exploração do petróleo no Espírito Santo. Revista de direito econômico e socioambiental, Curitiba, v. 3, n. 1, p. 79-105, jan/jun, 2012.

SAMPAIO, Rômulo Silveira da Rocha. LAMARE, Julia Macedo de. KLOSS, Viviane Damato Otto. Regulação ambiental e a tragédia dos antibens comuns: análise da eficiência e efetividade aplicáveis ao regime de competência em matéria de licenciamento ambiental. Revista Direito Ambiental e sociedade, v. 6, n. 1, 2016 (p. 177-200).

SÁNCHEZ, Luis E. Para que serve (ou deveria servir) o licenciamento ambiental? Jornal da USP. Disponível em: https://jornal.usp.br/?p=327204. Acesso em 01 jul. 2021. 


\section{CAPITULO IV}

\section{A EFICIÊNCIA DA AUTOFALÊNCIA: ANÁLISE CUSTO-BENEFICIO DE UM INSTITUTO ESQUECIDO NO ORDENAMENTO JURÍDICO}

DOI: 10.51859/AMPLLA.EDL1037-4

João Elias Chaves de Souza ${ }^{1}$

${ }^{1}$ Graduando em Direito pela Universidade do Estado da Bahia. Graduado em Gestão Financeira pela UNINTER. Atua como estagiário na Procuradoria Federal junto à Univasf.

\section{RESUMO}

O objetivo do artigo é analisar a eficiência do instituto da autofalência (falência requerida pelo próprio devedor). $\mathrm{O}$ artigo observa a Lei de Recuperação de Empresas e Falência (LREF) com o auxílio da Análise Econômica do Direito visando à análise dos custos de falência da autofalência e os benefícios trazidos ao optar pelo instituto, como a proteção ao patrimônio dos sócios e outras vantagens introduzidas em decorrência da alteração da Lei no 11.101/2005 pela Lei no 14.112/2020. Trata-se de uma pesquisa descritiva, cuja metodologia empregada consiste em pesquisa bibliográfica e jurisprudencial principalmente na área do Direito Empresarial, Direito Falimentar e Análise Econômica do Direito. Ao final, conclui-se que a autofalência é um mecanismo viável que visa a diminuir os custos sociais de uma futura recuperação judicial infrutífera, diante da preocupação do Estado com a crise financeira e econômica de uma empresa.

Palavras-chave: Análise Econômica do Direito. Autofalência. Direito Falimentar. Eficiência 


\section{INTRODUÇÃO}

O presente trabalho visa a utilizar a Análise Econômica do Direito (AED) para desenvolver um estudo sobre o instituto da Autofalência, investigando quais os custos sociais e a eficiência envolvida nos casos falimentares. Em relação ao conceito de Análise Econômica do Direito para o estudo em questão, vê-se a relevância quanto à aplicação do critério econômico da eficiência (maximização da riqueza) na escolha pelo empresário do procedimento a ser seguido diante de uma crise falimentar.

Em se tratando de crises econômicas e financeiras, o desejável é que os empresários encontrem as soluções para estas crises através de acordos negociados no mercado, sempre tomando como parâmetro a boa-fé objetiva, seja numa esfera de consumo, seja numa esfera empresarial.

No entanto, sabe-se que nem sempre é possível encontrar a solução pela atuação do mercado, impondo-se soluções legais para essas crises. No Brasil, a Lei no 11.101/2005 é a responsável pelo tratamento legal das crises com os mecanismos da recuperação judicial, da recuperação extrajudicial e da falência. Destaca-se que a Lei de Recuperações de Empresas e Falências foi recentemente alterada pela Lei $\mathrm{n}$ ㅇ $14.112 / 2020$.

Desse modo, os institutos da recuperação e falência são instrumentos por meio dos quais o empresário pode superar a situação de crise no exercício da atividade econômica, a fim de propiciar a preservação de sua empresa, ou então, realizar o encerramento regular de sua atividade empresarial, assegurando nesses casos, a realização da função social da atividade econômica.

No entanto, há casos que, por não ser viável a recuperação judicial, tem-se na falência da empresa a única solução. O pedido de falência requerido pelo próprio devedor (autofalência) diminui os custos sociais de uma futura recuperação judicial infrutífera, pois a crise financeira e econômica de uma empresa é alvo de preocupação do Estado e, por isso, uma recuperação judicial falha seria um custo desnecessário para a sociedade, que aloca recursos para a manutenção de uma empresa que não é mais viável, gerando uma diminuição da riqueza.

Por isso, para tratarmos da falência e analisarmos a eficiência do instituto da autofalência no ordenamento jurídico brasileiro, faz-se necessário analisar os custos 
sociais e a eficiência envolvida nos casos falimentares segundo os estudos da Análise Econômica do Direito.

\section{A ANÁLISE ECONÔMICA DO DIREITO E A LEI DE RECUPERAÇÃO DE EMPRESAS E FALÊNCIA}

Compreende-se a análise econômica do direito como sendo a utilização da abordagem econômica para tentar compreender o direito no mundo e o mundo no direito. Nesse sentido, como exposto por Cooter e Ulen (2016, pg. 21), “o direito necessita da economia para compreender suas consequências no comportamento e a economia necessita do direito para entender os fundamentos dos mercados"1.

Desse modo, a abordagem juseconômica investiga as causas e as consequências das regras jurídicas e de suas organizações na tentativa de prever como os indivíduos se comportam diante de uma dada regra (incentivos) e como alteram seu comportamento caso esta regra seja modificada (GICO JÚNIOR, 2019). Com base no postulado da escassez dos recursos econômicos, os indivíduos são obrigados a fazer escolhas para maximizar os seus interesses. Pressupõe-se que as escolhas sejam feitas de forma racional, ou seja, os indivíduos escolhem suas próprias preferências por meio da análise de custo-benefício e, portanto, são suscetíveis a incentivos normativos.

No entanto, a AED entende que, devido à falta ou assimetria de informação, os custos de transação limitam a racionalidade dos indivíduos. Por isso, as escolhas devem ser feitas de forma eficiente para se obter a melhor utilização dos recursos. Uma tomada de decisão eficaz significa que os indivíduos podem melhorar sua situação sem piorar a situação dos outros ou, pelo menos, compensar suas perdas.

Segundo Salama (2008), uma das acepções mais comuns (da AED) diz respeito à maximização da riqueza e do bem-estar e à minimização dos custos sociais. Desta forma, um processo será considerado eficiente se não for possível aumentar os benefícios sem também aumentar os custos. Nesse diapasão, explica o referido Autor (SALAMA, 2008, p. 42),

\footnotetext{
1 "El derecho necesita a la economía para comprender sus consecuencias en el comportamiento, y la economía necesita al derecho para entender los fundamentos de los mercados."
} 


\begin{abstract}
Em países em desenvolvimento como o Brasil, o emprego eficiente dos recursos existentes deve ser uma prioridade nacional. Para enfrentar seus problemas, a sociedade brasileira necessita de instrumentos jurídicos eficientes que estimulem as atividades produtivas, a resolução de conflitos de forma pacífica, a democracia, a livre iniciativa, a inovação, e a redução da corrupção e da burocracia, do desperdício e da pobreza. O estudo dos incentivos postos pelos institutos jurídicos faz parte deste esforço, e os estudiosos do Direito podem e devem tomar parte neste processo.
\end{abstract}

Para Salama (2008), a escassez força os indivíduos a realizarem escolhas e incorrerem em tradeoffs ("sacrifícios"); isso porque, para se ter algo, é preciso dispensar a oportunidade de se obter outra coisa, surgindo daí a ideia de "custo de oportunidade"1. Importante destacar que a eficiência de um processo recuperatório está associada à forma pela qual seus custos - sejam eles, financeiros, reputacionais e de oportunidade - podem ser alocados entre os agentes econômicos que se relacionam com a organização empresarial em crise (PATROCÍNIO, 2013).

Ademais, com o advento da Revolução Industrial e do processo de Globalização, ocorreram relevantes alterações na conjuntura socioeconômica, que exigiram do operador jurídico uma completa reformulação dos princípios e institutos do direito falimentar, que surgem desde a Roma Antiga e foram sendo revistos e modificados ao decorrer do tempo (RAMOS, 2017). Segundo Ramos (2017, pág. 736):

\begin{abstract}
A noção de insolvência com um sentido pejorativo - como algo, enfim, ocorrente apenas ao devedor desonesto - começa a ser revista, passando a ser considerada um fenômeno normal, inerente ao risco empresarial.
\end{abstract}

A crise econômica e financeira de uma empresa, por trazer efeitos para toda a sociedade, deve ser alvo de preocupação do Estado. Com isso, este é levado a criar mecanismos que possam amenizar suas consequências (LANA, 2020). Desse modo, Lana (2020, pág. 2) disserta que

O Estado cria normas para regular o procedimento para empresas em crise,
visando à satisfação de seus credores, sejam eles trabalhadores, os
fornecedores e a própria comunidade em que a empresa se encontra
inserida, os quais confiaram no desenvolvimento de uma atividade que não
teve êxito e adentrou em crise.

A legislação recuperatória deve conter normas que resultem na diminuição dos custos de transação que existiriam nas negociações entre credores e devedores (PATROCínIO, 2013). Com o advento da Lei no 11.101/2005, denominada de Lei de

\footnotetext{
${ }^{1}$ Nesse sentido, Salama (2008) explica, "Isso quer dizer que nem tudo pode ser feito ou produzido; tudo tem um custo; e cada centavo gasto em uma determinada atividade, é o mesmo centavo que não é gasto em todas as demais".
} 
Recuperação de Empresas e Falência (LREF), o sistema concursal evoluiu, adequando os seus institutos à dinâmica econômica do final do século XX e à tendência normativa de sistemas concursais mais complexos.

Em consonância com as tendências concursais contemporâneas, a LREF alterou não apenas a sistemática legal relacionada à falência, mas propôs verdadeira revolução na cultura jurídica relacionada à crise, visando a possibilitar a negociação entre credores e devedor, no intuito de conseguir encontrar alternativas viáveis para superação das crises (APOLINÁRIO, 2018). Desse modo, torna-se salutar pensar a LREF sob a ótica da Análise Econômica do Direito (AED). Ademais, a eficiência do sistema falimentar deve ser o objetivo que norteia qualquer processo de recuperação em que se pretenda um mecanismo justo, célere e que preserve, na medida do possível, a entidade econômica (SADDI, 2019).

A Lei no 14.112/2020 trouxe alterações à LREF, dispondo que a falência também é mecanismo de preservação dos benefícios econômicos e sociais decorrentes da atividade empresarial. Dessa forma, ambas as ferramentas do tratamento da insolvência no Brasil possuem objetivos comuns, embora os métodos para a sua consecução sejam diferentes.

No caso da recuperação judicial, tem-se uma empresa em crise, porém viável. Assim, busca-se criar condições para superação do seu declínio através da negociação entre os agentes do mercado. Por outro lado, na falência, tem-se uma empresa em recessão em razão de sua total inviabilidade, não havendo possibilidade de sua manutenção (COSTA, 2021).

Assim, a falência visa preservar os benefícios econômicos e sociais decorrentes da atividade empresarial pela liquidação imediata do devedor, abrindo espaço no mercado para o surgimento de uma nova atividade empresarial geradora de empregos, tributos, produtos, serviços e riquezas, bem como pela realocação útil dos ativos da falida em outras cadeias produtivas (COSTA, 2021).

No entanto, para que a falência seja eficiente e funcione como um instrumento de saneamento do mercado, é necessário que também viabilize ao empreendedor uma nova chance, um recomeço na atividade empresarial (COSTA, 2021). 


\section{AUTOFALENECIA: UM INSTITUTO ESQUECIDO NO ORDENAMENTO JURÍIICO}

A autofalência, ou confissão da falência, encontra-se instalada nos arts. 105, 106 e 107, na Seção VI - Da Falência Requerida pelo Próprio Devedor - da Lei no 11.101/05. É um instituto que merece atenção, pois, apesar de não ser corriqueiro no ordenamento pátrio, pode ser de grande valia quando não há outra alternativa à sociedade empresária para superar a crise financeira que eventualmente atravesse sem a possibilidade de reestruturação do empreendimento através de negociações ou da recuperação judicial.

Nesse sentido, nota-se que o devedor em crise costuma tomar duas atitudes: 1) não aceitar que sua crise é irremediável, insistindo na atividade até ter, eventualmente, a sua falência decretada a pedido de terceiro, normalmente um credor; ou 2) encerrar o exercício da atividade empresarial, muitas vezes sem a observância das regras legais impostas para tanto (RAMOS, 2017).

Se a recuperação judicial deve ser requerida pelo devedor que entende que a crise é superável, da mesma forma, deve-se tomar a iniciativa de requerer a autofalência quando se verificar que o declínio não pode ser solucionado, liquidando o seu patrimônio. Trata-se de uma confissão da situação de insolvência e da impossibilidade de superação desse estado (TOMAZETTE, 2017).

Dessa forma, em tese, se não houver demonstração de viabilidade de crescimento e interesse social, a empresa não terá outro destino que não seja a falência (LANA; PIMENTA, 2020). A LREF estabelece uma separação essencial entre as empresas economicamente viáveis e inviáveis. Por conseguinte, são consideradas viáveis aquelas que apresentam condições para arquitetar um plano de reorganização estabelecido pela LREF. Esta viabilidade depende de alguns fatores, como nível de endividamento, importância econômica da atividade, tempo de constituição, faturamento anual entre outros.

Em caso de observância da impossibilidade de cumprimento do plano estabelecido pela LREF, será indeferida a pretensão de recuperação da empresa. Na hipótese de a constatação ser feita apenas após o início do processo de recuperação, o mesmo será revertido em solução liquidatória. 


\section{O princípio da viabilidade da empresa tem como objetivo analisar o}

enquadramento da sociedade empresária nas hipóteses de recuperação ou não, observando as modalidades de crise, que podem ser: liquidez, insolvência e situação patrimonial que dependerá de readequação. Por isso, a verificação da viabilidade de recuperação é essencial na medida em que se objetiva a preservação da empresa e se protege o direito dos credores. Visa-se, portanto, a não causar frustração, gastos desnecessários ou qualquer prejuízo aos diretamente envolvidos e nem à sociedade, considerando o seu conteúdo e seus efeitos, pois a reorganização de atividades econômicas é, de fato, custosa e, consequentemente, a sociedade acaba por pagar a recuperação dessas empresas.

Nesse sentido, Coelho (2011) ressalta que a reorganização da atividade econômica é um procedimento custoso, que envolve risco para os credores, e que, em última análise, como os principais agentes econômicos acabam repassando aos seus respectivos preços as taxas de riscos associados à recuperação judicial ou extrajudicial do devedor, o ônus da reorganização das empresas no Brasil recai na sociedade brasileira como um todo. A LREF, em seu art. 105, impõe ao próprio devedor a obrigação de requerer a autofalência quando estiver insolvente (sem a possibilidade de pleitear a recuperação judicial). Entretanto, mesmo sendo um dever, a legislação falimentar não regulou sanções cabíveis para o descumprimento dessa medida. Nesse sentido, Coelho (2012, p. 325) complementa:

Trata-se, porém, de obrigação desprovida de sanção. Nenhum devedor, por
isso, costuma requerer a autofalência como manda a lei, e, mesmo assim, não
sofre punição nem enfrenta qualquer consequência. O requerimento da
autofalência deve ser entendido, assim, como recomendação ao empresário
insolvente que não reúne as condiçães para obter em juízo a reorganização
de sua empresa.

Ademais, Silva (2009, p. 92) explica os requisitos da autofalência,

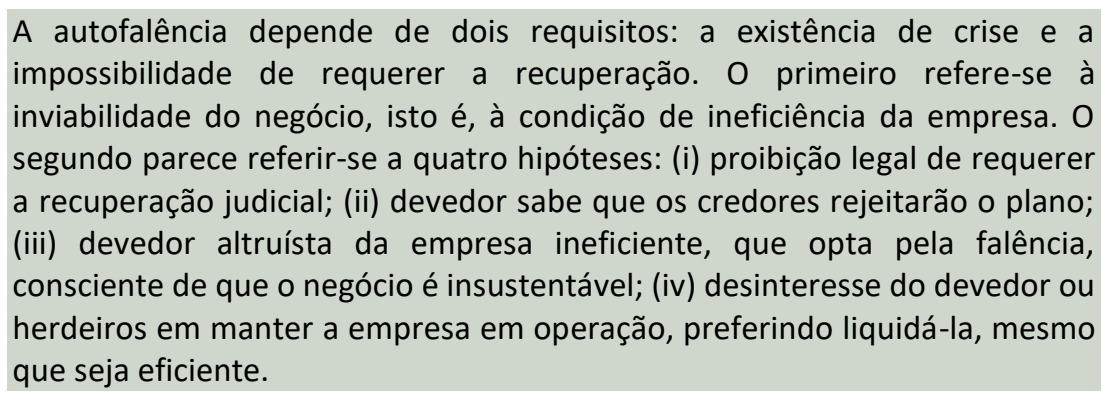


Portanto, o empresário consciente, de que sua situação econômica não permite pleitear perante a justiça sua recuperação judicial, requererá em juízo sua autofalência, com base nos artigos 105, 106 e 107 da LREF.

\section{PROTEÇÃO AO PATRIMÔNIO DOS SÓCIOS}

A garantia que os ativos representam, no tocante à liquidação de obrigações, pode redundar em frustração de expectativas dos credores. Por isso que, visando ao estabelecimento de uma disciplina que iniba comportamentos indesejáveis, o legislador impõe ao empresário o dever de requerer a autofalência, reduzindo a possibilidade de avanços sobre ativos, líquidos ou de fácil liquidação, em detrimento dos credores (FRANCO; SZTAJN, 2008).

Além de proporcionar proteção aos credores, a autofalência também protege o patrimônio pessoal dos sócios de uma sociedade empresária, já que permite o encerramento regular da atividade empresarial. Isto porque muitos empresários desconhecem a maneira correta para a dissolução regular de sua firma individual ou sociedade mercantil; outrossim, são afastados pela burocracia das juntas comerciais (MARTINS, 2016).

Ademais, Martins (2016) ressalta que o fechamento irregular das empresas expõe os empresários aos riscos da desconsideração da personalidade jurídica: os empresários que assim encerram suas atividades podem responder com seus patrimônios pessoais pelas dívidas da pessoa jurídica.

Diante desta situação, o Superior Tribunal de Justiça pacificou e solidificou o entendimento de que não pode haver responsabilização dos sócios em relação à dissolução regular da empresa, diferentemente do que seria se fosse uma dissolução irregular passível de fraude ou crime falimentar ${ }^{1}$.

\footnotetext{
${ }^{1}$ 2. Em suas razões, os agravantes afirmam que não há como imputar a responsabilidade pelo débito fiscal mediante redirecionamento se a empresa em questão foi dissolvida de forma regular mediante autofalência. (...) 9. Em outra oportunidade, esta Corte entendeu que a autofalência é faculdade estabelecida em lei em favor do comerciante impossibilitado de honrar seus compromissos, não se configurando hipótese de dissolução irregular (REsp. 644.093/RS, Rel. Min. FRANCISCO PEÇANHA MARTINS, DJ 24.10.2005, p. 258). (...) 11. Dessa forma, verifica-se que se está diante de uma dissolução regular, a autofalência, o que não autoriza o redirecionamento da execução fiscal aos administradores. (STJ - AgRg no AREsp: 192771 RS 2012/0126842-7, Relator: Ministro NAPOLEÃO NUNES MAIA FILHO, Data de Publicação: DJ 05/06/2015) - grifo nosso.
} 
Nesse sentido, faz-se necessário salientar que há três tipos de sociedades, no ordenamento jurídico brasileiro, que apresentam a responsabilidade ilimitada de seus sócios pelas obrigações da sociedade: sociedade em conta de participação; sociedade em nome coletivo e sociedade em comandita simples. Seus sócios, embora não sejam considerados falidos, além de estarem inabilitados para o exercício da atividade empresarial, possuirão responsabilidade ilimitada pelas obrigações sociais (MARTINS, 2016).

Por outro lado, em sociedades limitadas ou anônimas, o sócio ou acionista não tem responsabilidade pelas obrigações sociais desde que o capital social esteja inteiramente integralizado. Entretanto, segundo Martins (2016), ainda que o capital social não esteja totalmente integralizado e todos respondam solidariamente até a integralização do capital social, os bens particulares dos sócios não estarão sujeitos à constrição judicial na execução falimentar.

Acrescente-se que as mudanças introduzidas pela Lei $n$ o 14.112/2020 modificou o tratamento que a Lei no 11.101/05 conferia ao empresário falido, no que tange às extinções de suas obrigações e a sua reabilitação para voltar a empreender, posto que anteriormente condenava o falido a uma pena por prazo indefinido de inabilitação comercial. Conforme dispunha o sistema revogado, o falido ficava inabilitado para exercer qualquer atividade empresarial a partir da decretação da falência e até a sentença que extinga as suas obrigações.

Assim, o art. 158 da Lei no 11.101/05, antes da reforma, dispunha que as obrigações do falido seriam extintas somente ao término do processo de falência, mediante o pagamento integral dos créditos ou mediante o pagamento de mais de $50 \%$ dos créditos quirografários. Caso não existisse ativo suficiente para esses pagamentos, a extinção das obrigações do falido ocorreria somente depois do decurso do prazo de 5 anos contados do encerramento da falência (se o falido não tiver sido condenado por prática de crime falimentar), ou de 10 anos, se o falido tiver sido condenado por prática de crime falimentar.

Tendo em vista que o sistema revogado vinculava o início do prazo de reabilitação do falido - em casos de falências sem ativos suficientes para o pagamento dos credores - ao encerramento do processo de falência, ele ficava, na prática, condenado a uma pena quase que perpétua de inabilitação comercial (COSTA, 2021). 
Assim, o tratamento legal anterior colocava um pesado ônus sobre o empresário, fazendo com que ninguém desejasse buscar a decretação de sua falência, na medida em que ficaria vinculado a um processo de longuíssima duração sem a oportunidade de poder empreender novamente.

Nesse sentido, o novo sistema trazido pela Lei no 14.112/2020 facilitou a extinção das obrigações do falido ao diminuir de $50 \%$ para $25 \%$ o limite mínimo de pagamento dos credores quirografários (art. 158, II); e, principalmente, ao dispor que, decorrido o prazo de três anos da decretação da quebra (conhecido como fresh start), o falido poderá extinguir as suas obrigações mediante a entrega do patrimônio sujeito à falência (art. 158, V). Ademais, o art. 159 dispõe que, nestas hipóteses, o falido poderá requerer ao juízo de falência que suas obrigações sejam declaradas extintas por sentença.

Ademais, o fresh start está positivado como princípio a ser buscado na falência (art. 75), mas é aplicável ao empresário individual. Há também a possibilidade de extinção das obrigações do falido em prazos menores e condições menos onerosas (art. 158). Desse modo, o novo sistema de insolvência empresarial brasileiro, ao permitir que o falido possa voltar às atividades empresariais em prazo razoável (três anos depois da decretação da falência), passa a oferecer mecanismos de incentivo para que os empresários e sociedades empresárias atuem de forma mais eficiente em face de uma situação de inviabilidade da empresa.

Segundo Costa (2021), com as alterações trazidas pela Lei $n$ 우 14.112/2020, surge uma consequência ainda pouco percebida da nova regulação: a autofalência se torna uma opção interessante para o enfrentamento da crise de uma empresa inviável. Outrossim, a autofalência traz benefícios ao devedor que faça uso desse instituto em relação aos débitos tributários e trabalhistas, inclusive, para uma possível reestruturação no futuro.

Tratando especificamente dos débitos tributários, o Tribunal Regional Federal da 2a Região, utilizando entendimento já pacificado pelo Superior Tribunal de Justiça, decidiu que a decretação da falência da empresa, na forma da lei, não configura 
dissolução irregular e, por isso, não pode ser interpretada em desfavor do devedor, impedindo que haja a penhora dos bens particulares dos sócios pela Fazenda Pública ${ }^{1}$.

Percebe-se, com base no julgado (AC 200451015037049, Desembargador Federal LUIZ ANTONIO SOARES, TRF2 - QUARTA TURMA ESPECIALIZADA, E-DJF2R Data:25/08/2014), que não haverá redirecionamento de débitos tributários em face dos sócios da sociedade de responsabilidade limitada e da sociedade anônima falida, uma vez que o requerimento de autofalência faz prova da dissolução regular da empresa. No caso dos débitos trabalhistas, Carmo (2011) defende que, decretada a falência da empresa, e uma vez comunicado o fato ao juízo trabalhista, não pode este último, para assegurar o pronto pagamento dos créditos trabalhistas, ignorar a quebra e decretar a despersonalização da pessoa jurídica para, a partir daquela comunicação, executar bens pessoais de seus sócios.

Desta forma, observa-se que o objetivo da Lei no 11.101/05, ao tratar da desconsideração da personalidade jurídica da empresa visando a atingir o patrimônio pessoal do empresário, é punir aquele que age irregularmente, com fraude, em relação aos credores, e não punir aquele que não possui patrimônio suficiente para saldar suas dívidas, razão pela qual nem os créditos trabalhistas podem atingir o patrimônio pessoal do sócio da empresa falida.

1 EXECUÇÃO FISCAL. FALÊNCIA. PROSSEGUIMENTO. AUSÊNCIA DE INTERESSE DE AGIR. REDIRECIONAMENTO DA EXECUÇÃO EM FACE DOS SÓCIOS. INOCORRÊNCIA DAS SITUAÇÕES ELENCADAS NO ART. 135, III DO CTN. IMPOSSIBILIDADE. 1-O STJ já decidiu que encerrado o processo de falência, sem resíduos de bens, não há interesse processual no prosseguimento da execução fiscal. 2-A decretação de falência da empresa, na forma da lei, não configura dissolução irregular e, por isso, não pode ser interpretada em desfavor do devedor. Nos casos de quebra da sociedade, a massa falida responde pelas obrigações da empresa executada até o encerramento do processo de falência e o redirecionamento somente é autorizado em caso de comprovação da responsabilidade subjetiva, incumbindo ao Fisco a prova de gestão praticada com dolo ou culpa, de modo que a ausência de requerimento de autofalência, por não consubstanciar obrigação tributária, também não se traduz em causa de redirecionamento da execução fiscal em face do sócio. 3-A extinção do processo falimentar sem resíduos de bens não implica na responsabilidade dos sócios, sendo certo que a desconsideração da personalidade jurídica da empresa falida somente se recomenda nas hipóteses em que é a mesma utilizada para fraudar credores ou a própria lei, o que não se comprovou, na hipótese, pelo menos até o presente momento, segundo a prova nos autos. 4-Apelação não provida.

(AC 200451015037049, Desembargador Federal LUIZ ANTONIO SOARES, TRF2 - QUARTA TURMA ESPECIALIZADA, E-DJF2R - Data:25/08/2014) - grifo nosso 


\section{ANÁLISE ECONÔMICA DA AUTOFALÊNCIA}

Recorda-se que, com o advento da Lei no 11.101/2005, foi inserido no ordenamento jurídico o instituto da Recuperação de Empresas, substituindo o antigo instituto da concordata. Segundo Perin Junior (2011, p. 357), os objetivos da Recuperação são:

1) Facilitar a recuperação de empresas e, consequentemente, manter o nível de emprego, a arrecadação de tributos e, fundamentalmente, a possibilidade de circulação de bens e serviços;

2) Dar maior agilidade para que credores possam reaver, com uma segurança jurídica mínima, seus bens e direitos. Como terão mais garantias sobre o crédito concedido espera-se, ainda, que os encargos cobrados para compensar a inadimplência sejam reduzidos.

Percebe-se, pela narrativa da legislação falimentar, que a Recuperação Judicial é a regra; e, a Falência, a exceção, pois que a LREF tem como princípio a manutenção da empresa (art. 47), eis que ela traz benefícios à sociedade: oferta de emprego, pagamento de impostos, estímulo à concorrência etc.; diferentemente dos reflexos provocados por sua quebra (MARCHI et al, 2018).

Nesse sentido, podemos concluir que o princípio da função social da empresa perpassa pela compreensão do papel e da relevância - tanto econômica, quanto social - desempenhados pela atividade empresarial, no atual modelo de organização estatal e, por decorrência, da sua importância para a sociedade como um todo, não apenas para permitir a realização dessa atividade, mas também instituindo limites para o seu exercício (APOLINÁRIO, 2018).

Dessa forma, conforme aduz Martins (2016, p. 60), "a função social da empresa consiste, pois, no fato de que o empresário ou administrador da empresa assume o poder-dever de conciliar a atividade empresarial com a observância de um plexo de deveres jurídicos, positivos e negativos, em benefício da vida social".

No entanto, à medida que a extinção da empresa gera externalidades negativas à toda sociedade, o soerguimento de uma empresa economicamente inviável também se torna nocivo (MAMEDE, 2017). Portanto, a inviabilidade econômica constitui requisito indispensável para a objeção do plano quando da aprovação do pedido, momento em que também se realiza a análise da função social da empresa no mercado no qual atua (MARCHI et al, 2018). 
Desse modo, na medida em que a empresa possui relevante função social para o crescimento e desenvolvimento da sociedade na qual está inserida, impõe-se a observância da necessidade de se preservar o meio de produção para que continue a exercer a pretendida função social (BALDINOTI; ZERBINI, 2018).

Sztajn (2005) explica que a empresa vista como atividade econômica tem como objetivo a criação de riqueza. Por conseguinte, ao não cumprir com esse objetivo, as opções de falência, reorganização ou recuperação, quando assentadas em princípios econômicos, são alternativas adequadas a fornecer incentivos a sua continuidade.

No entanto, fornecer incentivos para recuperar uma empresa inviável ou mesmo incentivar uma empresa economicamente viável a falir são dois comportamentos evidentes em termos de ineficiência econômica. Por fim, vê-se que empresas inviáveis tentam postergar a inevitável falência através do ajuizamento de recuperações judiciais (que já surgem sem chances de êxito).

As alterações trazidas pela Lei no 14.112/2020, dessa maneira, visam a criar um processo célere de falência, com venda rápida de ativos - e até mesmo possibilidade de doação de ativos sem interessados - e redução dos questionamentos sobre esse ponto, inclusive imputando responsabilidade e ônus aos insurgentes (art. 143).

Portanto, a intenção do legislador foi tornar mais célere o trâmite da recuperação judicial e da falência, objetivando um recomeço mais rápido para as empresas com vistas à realocação eficiente de recursos na economia e a mitigar os custos sociais referentes aos procedimentos falimentares.

\section{CUSTOS REFERENTES À FALÊNCIA}

Com isso, faz-se necessário tecer comentários acerca dos "custos de falência". Esta expressão geralmente é utilizada para indicar o risco de insolvência de uma empresa em função de seu endividamento, no âmbito de finanças, que são classificados em diretos e indiretos. No entanto, a expressão também é utilizada para se referir aos custos envolvidos na condução de processos de reorganização ou de liquidação recuperação ou falência, respectivamente (JUPETIPE et al, 2017).

Os primeiros são gastos relacionados diretamente ao processo jurídico, tais como honorários do administrador judicial e de peritos, e custas judiciais; já os custos indiretos são os custos de oportunidade nos quais as empresas incorrem por 
participarem de um processo falimentar ou de recuperação, como o tempo despendido no processo, dificuldade de obtenção de crédito, queda de receita operacional, recebimento da dívida com deságio, entre outros.

A quebra de uma empresa gera custos não somente a seus participantes diretos, mas também para toda a sociedade, pois que há perda de empregos, de arrecadação de tributos, redução de oferta de produtos e serviços. Em relação à recuperação, tem-se o risco de conceder esse benefício legal a uma empresa inviável e, assim, apenas postergar sua liquidação pela falência (efeito procrastinador). No caso, ocorrem perdas maiores se comparadas às perdas de uma falência que poderia ter sido antecipada (JUPETIPE et al, 2017).

Conforme o levantamento da SERASA Experian, foram ajuizados 13.295 (treze mil, duzentos e noventa e cinco) pedidos de Recuperação Judicial entre junho de 2005 e agosto de 2020, dos quais 4.292 (quatro mil, duzentos e noventa e dois) foram concedidos, demonstrando que aproximadamente $32 \%$ (trinta e dois por cento) dos processos envolvendo esse instituto lograram o seu objetivo (SERASA, 2020).

No entanto, esses dados não apontam quantos processos foram efetivamente encerrados decorrido o prazo de fiscalização de dois anos, previsto no art. 61 da Lei no 11.101/2005, ou ainda qual o número dos que foram convolados em falência em virtude de descumprimento de cláusulas do plano de recuperação judicial - art. 73 da referida lei -, dados relevantes para se apurar o índice de efetividade da Recuperação Judicial.

Diante desses dados, é inegável que a eficácia dos procedimentos de recuperação judicial do Brasil é extremamente baixa, o que prejudica, na prática, a análise da viabilidade econômica desses processos, apesar de existir, teoricamente, a indicação positiva do seu papel de instrumento de redução dos custos de transação, se comparado aos outros procedimentos previstos na Lei $n=11.101 / 2005$. Ou seja, em tese, os custos de transação são menores nos procedimentos de recuperação judicial do que nos procedimentos de falência.

Como os custos de transação no procedimento da autofalência não se efetivam, os custos da ineficiência da norma acabam sendo maiores, haja vista os prejuízos suportados pela sociedade com a não recuperação das empresas (APOLINÁRIO, 2018). 


\section{CONSIDERAÇ̃̃ES FINAIS}

Partindo do pressuposto do instituto da autofalência como um mecanismo viável que visa a diminuir os custos sociais de uma futura recuperação judicial infrutífera, diante da preocupação do Estado com a crise financeira e econômica de uma empresa. Tendo em vista que uma recuperação judicial falha seria um custo desnecessário para a sociedade, pois aloca recursos para a manutenção de uma empresa que não é mais viável, gerando uma diminuição da riqueza.

Assim, o estudo demonstrou com o auxílio de conceitos da Análise Econômica do Direito, os custos envolvidos e a eficiência na condução de procedimentos adotados no regime de insolvência - enfatizando o instituto da autofalência, como alternativa às empresas quando a recuperação judicial for inviável. Dessa forma, analisou-se os custos de falência (diretos e indiretos) e os dados referentes à insolvência no país desde a promulgação da Lei 11.101/2005 a fim de encarar a eficiência nos procedimentos falimentares.

Para tanto, inicialmente, realizou-se uma análise do instituto da autofalência, tratando da sua aplicação, proteção ao patrimônio pessoal dos sócios diante da hipótese de desconsideração da personalidade jurídica em situação de execução tributária e trabalhista - sendo, portanto, um encerramento regular da atividade empresarial.

Posteriormente, fez-se uma abordagem, de forma científica, mediante o enfoque da Análise Econômica do Direito (AED), aliada às suas ferramentas metodológicas, tais como incentivos, maximização de riqueza, externalidades, custos de transação, escassez e eficiência.

Devido às dificuldades em analisar os dados referentes aos procedimentos falimentares, eis que estes não apontam quantos processos foram efetivamente encerrados decorrido o prazo de fiscalização de dois anos ou ainda qual o número dos que foram convolados em falência em virtude de descumprimento de cláusulas do plano de recuperação judicial, dados relevantes para se apurar o índice de efetividade da Recuperação Judicial.

Portanto, a finalidade da pesquisa bibliográfica visou a compreender o instituto da autofalência sob o viés da Análise Econômica do Direito ao concluir pela viabilidade do uso do mecanismo, ainda mais após as alterações trazidas pela Lei no 14.122/2020, 
que incentivam a empresa em situação de inviabilidade a requerer a autofalência. Desse modo, propõem-se pesquisas sobre os casos em que empresas usaram da autofalência, de maneira a compreender na prática os benefícios de optarem pelo instituto.

\section{REFERÊNCIAS}

APOLINÁRIO, Bruno Alves. A Recuperação Extrajudicial de Empresas: Uma Abordagem à Luz da Análise Econômica do Direito. Tese (Mestrado em Direito) Universidade FUMEC, 2018.

BALDINOTI, Bruno; ZERBINI, Maiara Santana. A instituição de varas especializadas em recuperação judicial e (auto)falência sob a ótica da terceira onda renovatória. Revista Estudo \& Debate. Lajeado, v. 25, n. 3, 2018.

BRASIL. Lei n.o 11.101, de 9 de fevereiro de 2005. Regula a recuperação judicial, a extrajudicial e a falência do empresário e da sociedade empresária. Disponível em: $\quad$ http://www.planalto.gov.br/ccivil_03/_ato20042006/2005/lei/l11101.htm>. Acesso em: 03 de out. de 2020.

BRASIL. Lei no 14.112, de 24 de dezembro de 2020. Altera as Leis $n$ os 11.101 , de 9 de fevereiro de 2005, 10.522, de 19 de julho de 2002, e 8.929, de 22 de agosto de 1994, para atualizar a legislação referente à recuperação judicial, à recuperação extrajudicial e à falência do empresário e da sociedade empresária. Disponível em:

<http://www.planalto.gov.br/ccivil_03/_ato20192022/2020/lei/L14112.htm>. Acesso em 09 de out. de 2021

BRASIL. Superior Tribunal de Justiça. Agravo em Recurso Especial no 192.771/RS. Relator: Ministro Napoleão Nunes Maia Filho. Diário de Justiça Eletrônico, 05 de Junho de 2015.2 Disponível em: <https://stj.jusbrasil.com.br/jurisprudencia/195439973/agrg-no-agravo-emrecurso-especial-agrg-no-aresp-192771-rs-2012-0126842-7/decisaomonocratica-195439983?ref=juris-tabs>. Acesso em: 03 de out. de 2020.

BRASIL. Tribunal Regional Federal da 2a $\underline{a}$ Região. Processo de Execução Fiscal no 0538804-06.2003.4.02.5101/RJ. Disponível em: <https://trf2.jusbrasil.com.br/jurisprudencia/897147535/53880406200340251010538804-0620034025101/inteiro-teor-897147537?ref=amp>. Acesso em: 03 de out. de 2020.

CARMO, Júlio Bernardo do. Efeitos da Recuperação Judicial e da Falência Sobre o Processamento dos Feitos na Justiça do Trabalho. Migalhas. 2011. Disponível em: $<$ https://www.migalhas.com.br/depeso/144109/efeitos-da-recuperacaojudicial-e-da-falencia-sobre-o-processamento-dos-feitos-na-justica-dotrabalho>. Acesso em: 03 de out. de 2020. 
COELHO, Fábio Ulhoa. Curso de Direito Comercial, volume 3: direito de empresa. 13a edição. São Paulo: Saraiva, 2012.

COELHO, Fábio Ulhoa. Comentários à Lei de Falências e de Recuperação de Empresas. 8a edição. São Paulo: Saraiva, 2011.

COOTER, Robert. ULEN, Thomas. Derecho y Economía. Fondo de Cultura Económica, 2016.

COSTA, Daniel Carnio. A autofalência como instrumento de tratamento da crise da empresa. $\quad$ Migalhas. $2021 . \quad$ Disponível em: <https://www.migalhas.com.br/coluna/insolvencia-em-foco/346668/aautofalencia-como-instrumento-de-tratamento-da-crise-da-empresa>. Acesso em 11 de out. de 2021.

FRANCO, Vera Helena de Mello; SZTAJN, Rachel. Falência e recuperação da empresa em crise. Rio de Janeiro: Elsevier, 2008.

GICO JUNIOR, Ivo. Introdução ao direito e economia. p 1-32. In TIMM, Luciano Benetti. Direito e economia no Brasil: estudos sobre a análise econômica do direito.Indaiatuba-SP:Editora Foco, 2019

JUPETIPE, Fernanda. MARTINS, Eliseu. MÁRIO, Poueri. CARVALHO, Luiz. Custos de falência no Brasil comparativamente aos estudos norte-americanos. Revista Direito GV. $2017 . \quad$ Disponível em: <http://bibliotecadigital.fgv.br/ojs/index.php/revdireitogv/article/view/68895> . Acesso em: 10 de set. de 2020.

LANA, Henrique Avelino. Análise Econômica do Direito na Lei 11.101/2005: imprescindível compreensão conjunta entre recuperação de empresas, falência, direito e economia. Universidade FUMEC. Belo Horizonte. 2020. Disponível em: <http://www.fumec.br/revistas/meritum/article/view/6168>. Acesso em 27 de ago. de 2020.

LANA, Henrique Avelino; PIMENTA, Eduardo Goulart. Incompletude das informações na 11.101/05: uma abordagem mediante Análise Econômica do Direito. Revista Faculdade Direito UFMG. Belo Horizonte, n. 76, p. 263-298, 2020.

MAMEDE, Gladston. Manual de Direito Empresarial. 11a Ed. rev. e atual. - São Paulo: Atlas, 2007.

MARCHI, Giovanna. FERIATO, Juliana. MANSANO, Fernanda. Análise Econômica da Recuperação Judicial Consubstanciado nos Dados da SERASA Experian Sobre Falência e Recuperação Judicial Entre os Anos de 2005 a 2016. Economic Analysis of Law Review: Vol 9, No 1. 2018. Disponível em: <https://portalrevistas.ucb.br/index.php/EALR/article/view/8432>. Acesso em 22 de ago. de 2020. 
MARTINS, Adriano de Oliveira. Recuperação da Empresa em Crise: A Efetividade da Autofalência no Caso de Inviabilidade da Recuperação. Curitiba: Editora Juruá, 2016.

PERIN JUNIOR, Elcio. Curso de direito falimentar e recuperação de empresas, 4 a Ed. São Paulo: Saraiva, 2011.

RAMOS, André Luiz Santa Cruz. Direito Empresarial. 7ạ edição. Rio de Janeiro: Forense. 2017.

SADDI, Jairo. Análise econômica da falência. p 355-370. In TIMM, Luciano Benetti. Direito e economia no Brasil: estudos sobre a análise econômica do direito. Indaiatuba-SP: Editora Foco, 2019.

SALAMA, Bruno M. O que é Pesquisa em Direito e Economia?. In: Caderno Direito GV. São Paulo: FGV/EDESP, 2008. Disponível em: <http://works.bepress.com/bruno_meyerhof_salama> Acesso em: 12 de jul. de 2020.

SERASA EXPERIAN. Indicadores econômicos: recuperação judicial e falência. Disponível em: $\quad<$ https://www.serasaexperian.com.br/conteudos/indicadoreseconomicos/>. Acesso em: 11 de out. de 2020.

SILVA, Fernando César Nimer Moreira. Incentivos à decisão de recuperação da empresa em crise: análise à luz da teoria dos jogos. Tese (Mestrado em Direito). Orientação: Professora Rachel Sztajn. Faculdade de Direito da Universidade de São Paulo, 2009.

SZTAJN, Rachel. Notas sobre as assembleias de credores na lei de recuperação de empresas. Revista de Direito Mercantil, Industrial, Econômico e Financeiro. Vol. 138. pg. 53-70. São Paulo, 2005.

TOMAZETTE, Marlon. Curso de direito empresarial: Falência e recuperação de empresas, v. 3. 5a Edição. São Paulo: Atlas, 2017. 


\title{
CAPITULO V
}

\section{AS DIVERSIDADES E AS TICS NA EDUCAÇÃO: UMA ANÁLISE INCLUSIVA}

\author{
DOI: 10.51859/AMPLLA.EDL1037-5
}

Gabriela Soares Balestero ${ }^{1}$

\begin{abstract}
'Pós Doutoranda em Direito pela Universidade de Messina/Itália. Doutora em Ciências Jurídicas pela ACU. Doutoranda em Direito Constitucional pela Universidade de Buenos Aires. Doutoranda em História Social pela Universidade Federal de Uberlândia. Mestranda em Tecnologias Emergentes em Educação pela Must University.. Mestre em Direito pela Faculdade de Direito do Sul de Minas. Especialista em Direito Constitucional e em Direito Processual Civil pela FDSM. Bacharel em Direito pela FDSM. Licenciada em Sociologia pela Unip. Bacharela em Ciência Política pela Uninter. Licenciada em História pela Fiar. Professora do curso de Direito da Faculdade Pitágoras/Unopar de Pouso Alegre/MG, professora de Sociologia da rede estadual pública de ensino de Minas Gerais. Advogada.
\end{abstract}

\section{RESUMO}

O objetivo do presente estudo é entender a relevância da valorização da diversidade e da redução da desigualdade em um determinado cenário organizacional, inclusive instituições de ensino, foco do presente estudo e sugerir mudanças pedagógicas utilizando as tecnologias de informação como meios para a existência de um ambiente organizacional que pratique a inclusão. Sabe-se que a ideia básica da gestão da diversidade em qualquer instituição é a necessidade da prática do respeito, da empatia, da inclusão e do reconhecimento de modo que um ambiente produtivo efetivamente ocorra, onde todos se sintam valorizados e os talentos sejam utilizados em plenitude realmente exista. Somente assim, as finalidades plenas daquela instituição educacional conseguirão ser atingidos. Além disso nesse estudo temos como enfoque entender sobre os desafios da diversidade especialmente no campo educacional e discutir os desafios da gestão escolar. A metodologia a ser utilizada será analítico-discursiva e, no âmbito teórico, a revisão bibliográfica abrangerá bibliografia pública e acessível no meio acadêmico.

Palavras-chave: diversidade; inclusão; valorização. 


\section{INTRODUÇÃO}

Nossa sociedade passa por diversas transformações, positivas e negativas, onde a comunicação está no auge permeando toda a sociedade e sendo parte essencial do processo de socialização de todos os indivíduos, inclusive no ambiente educacional. Aprender a viver em um ambiente de diversidade é um dos principais desafios do mundocontemporâneo - e, portanto, da Educação.

Sendo assim, as novas tecnologias de informação e comunicação (TICS) juntamente com a ampliação da diversidade humana existente em nossas sociedades, são vetores importantes na transformação social e, portanto, a educação é um campo onde são necessárias mudanças que considerem essas transformação e reconheça as diferenças.

Sabe-se que a ideia básica da gestão da diversidade em qualquer instituição é a necessidade da prática do respeito, da empatia, da inclusão e do reconhecimento de modo que um ambiente produtivo efetivamente ocorra, onde todos se sintam valorizados e os talentos sejam utilizados em plenitude realmente exista. Somente assim, as finalidades plenas daquela instituição educacional conseguirão ser atingidos.

Nesse passo, ao longo da vida escolar, os educandos se deparam com todo tipo de diferença: de gênero, raça, valores, religião, expressão da sexualidade, ritmos de aprendizagem, configurações familiares etc. Diante dessa realidade, nós, educadores, pregamos o discurso da da prática da empatia, da alteridade e do reconhecimento de Direitos Humanos, como essenciais na sociedade como um todo, e, portanto, na vivência educacional. Portanto, analisar a inclusão educacional, o reconhecimento da diversidade, juntamente com a adoção de metodologias ativas que incluam as tecnologias de informação e comunicação (TICS), respeitando as diferenças, no meio escolar é de suma importância para uma educação de qualidade.

\section{GESTÃO DA DIVERSIDADE NO CAMPO EDUCACIONAL E TICS}

Falar em diversidade implica em dissertarmos sobre grupos minoritários e o preconceito que sofrem em nossa sociedade e não seria diferente no ambiente escolar. Inicialmente, vale destacar que a denominação minorias não está relacionada com a qualquer quantidade numérica e sim com um grupo de pessoas que se diferenciam da 
maioria, seja em virtude de algumas particularidades religiosas, étnicas ou grupos de pessoas com desejos em oposição aos da maior quantidade numérica. Ademais, o termo minorias também pode se referir a determinados grupos que não estão no poder ou que não possuem mecanismos democráticos de acesso ao poder ou de serem ouvidos por aqueles que detêm o poder. Portanto, é na manifestação de características discrepantes em quesitos tão primordiais à identidade e à virtual unidade de um povo - sua origem étnica, sua orientação religiosa e sua uniformidade linguística; elementos que o constituem como ente singular em relação aos demais povos do mundo -, que uma minoria destaca-se e torna-se visível dentre a totalidade da população (ANJOS, 2009, p. 331-332).

Ademais, o conceito de minorias está diretamente relacionado com a subjugação, ou seja, sempre que houver exclusão ou subjugação ${ }^{1}$ de um grupo em face da sociedade. De igual modo, vincula-se também ao critério numérico e às particularidades e diferenças na sociedade a que pertencem.

A expressão grupos vulneráveis estaria ligada à questão de poder perante a sociedade e à exclusão social como a que ocorre com os idosos, os deficientes, as crianças, os homoafetivos e as mulheres.

Nesse sentido, as mulheres podem ser consideradas um grupo minoritário diante da relação de subjugação, sendo submetidas à dominação política predominantemente masculina e, ao mesmo tempo, um grupo vulnerável, sujeito à exclusão social.

Inicialmente, o modelo neoliberal tentou impor uma igualdade formal para tentar garantir à mulher iguais chances e acesso ao mercado de trabalho, ao prestígio social e ao poder político. Contudo, tal igualdade, pregada de modo formal, infelizmente ainda não ocorre. Tal situação pode ser percebida pelo grande número de mulheres nas

\footnotetext{
1 “Um grupo numericamente inferior, possuidor de características étnicas, religiosas ou linguísticas peculiares, as quais deseja preservar - essa combinação de elementos encontra na ideia de subjugação o complemento necessário à definição de minorias. De fato, é a constatação de que uma parcela étnica, religiosa ou linguisticamente diferenciada da população de um país está submetida a algum tipo de dominação política por parte do grupo majoritário o dado que aperfeiçoa a conceituação de minoria, dando-Ihe um significado mais socialmente relevante, uma vez que é o que estabelece a real problemática do assunto. Exatamente: a importância da atenção ao tema das minorias não decorre da simples manifestação da diversidade representada pelas minorias existentes numa população; essa importância reside precisamente na ênfase conferida pelos estudiosos à situação de submissão dos integrantes do grupo minoritário aos desígnios da maioria. Neste contexto, é precisamente por se evidenciar a posição não dominante das minorias que se oferece a motivação para que se procure garantir a proteção das mesmas" (Cláudia Giovannetti Pereira dos ANJOS, 2009, p. 332).
} 
faixas salariais mais baixas, gerando uma nova forma de discriminação, ou seja, a existência de obstáculos à figura feminina no acesso a melhores salários e cargos. Portanto, é necessária uma mudança na compreensão paradigmática do direito.

A proteção contra a obstrução não basta; a correção das desigualdades devidas à diferença de peso social é exigida pela regra de justiça. A tolerância assume então um sentido positivo: à abstenção acrescenta-se o reconhecimento do direito de existência das diferenças e do direito às condições materiais de exercício de sua livre expressão (RICOEUR, 1995, p. 180). E, lamentavelmente as desigualdades também existem no ambiente escolar.

Sendo assim, podemos verificar que para o gerenciamento adequado da diversidade na gestão educacional é necessário o conhecimento da legislação pertinente, cooperação, a prática da empatia, da alteridade dentro da instituição de ensino. Destacamos que na maioria dos países, existem diversas leis para garantir o respeito e efetividade dos direitos humanos, como igualdade, não discriminação e dignidade da pessoa humana. Todavia, a não observância de leis que justamente visem garantir que as pessoas não sejam discriminadas em razão do gênero, da religião e da idade pode gerar a judicialização dessas questões em face das instituições educacionais.

Com a democratização do ensino e as novas oportunidades surgidas com o ensino houve também a emancipação do indivíduo no contexto social, a partir do momento em que os meios digitais possibilitaram a democratização do aprendizado, mas também favoreceram a produção de conhecimento individual e coletivo, através de ambientes interativos de aprendizagem, integrando pessoas, integrando diversidades. Sendo assim, o ambiente escolar não deve ser um "sistema fechado" e sim se abrir e "rever conceitos" (ALONSO, 2004).

\section{DESAFIOS DA DIVERSIDADE E DAS NOVAS TECNOLOGIAS NO CONTEXTO ESCOLAR}

A sociedade passa por diversas transformações, e o respeito às diversidades é pauta fundamental nesse mundo em constante modificação. Esta frase reflete a problemática existente: “Educar sem discriminar é uma tarefa difícil, pois muitos 
preconceitos e estereótipos ainda estão enraizados nas pessoas, tendo em vista os modelos culturais que lhe são impostos" (PESSANHA, TRINDADE e OLIVEIRA, 2002).

Sabemos que a escola é um espaço sociocultural onde as diferentes presenças, ou seja, as diversidades se encontram. Mas será que efetivamente essas "diferenças" tem sido respeitadas nas escolas? Há dificuldades em lidar em a diversidade na escola e, ao invés de produzir resultados positivos pode gerar problemas e dificuldades. Na sociedade contemporânea existe uma multiplicidade de culturas e trabalhar em sala de aula as pluralidades e diversidades não é uma tarefa fácil.

Tal complexidade evidencia a necessidade de se promover uma educação que ultrapasse o etnocentrismo sociocultural e rompa, assim, com a exclusão dos grupos sociais que não se enquadram nos grupos dominantes. Consoante o entendimento de Moreira (2004) podemos dizer que a escola muitas vezes se esquece ou até mesmo ignora o conhecimento e experiências diversas de divergentes grupos sociais, ou seja, indivíduos que possuem padrões culturais que não seria correspondentes aos moldes de uma cultura dita majoritária.

Sendo assim, há uma dificuldade do reconhecimento das diversas culturas tanto pela população de modo geral quanto pela própria instituição escolar, que, de certa maneira possuem uma concepção universalista do que seria cultura (balisadas nos padrões hegemônicos de cultura).

As instituições escolares ainda seguem a linha weberiana, ou seja, instituições que tem por escopo moldar os comportamentos das crianças e adolescentes, induzindo a seguirem determinados padrões de comportamentos. Segundo Moreira (2004) as políticas educacionais governamentais e institucionais são ainda permeadas e respaldadas pela ideologia de uma cultura homogênea, onde a educação teria como único ponto principal a formação de cidadãos que somente cumprem deveres, partilham os mesmos objetivos e uma única identidade, ou seja, a nacional.

Marilena Chauí conceitua a cultura com as seguintes palavras (2000, p. 295): “[...] a cultura é a maneira pela qual os humanos se humanizam por meio de práticas que criam a existência social, econômica, política, religiosa, intelectual e artística". Baseado no entendimento da autora, a cultura, portanto, não pertenceria a somente um grupo social dominante e sim estaria presente nos mais diversos grupos sociais e também nas individualidades das pessoas. Todos nós somos portadores de cultura, visto que 
carregamos conosco crenças, valores, constumes, tradições, sabedorias, visões do mundo particulares, que são transmitidos no seio familiar, que é o nosso grupo de socialização primário, e mais ainda, qua carregamos ao longo de gerações.

Além disso, as desigualdades sociais devem ser analisadas, inclusive em relação às dificuldades de acesso ao uso das TICS por alunos hipossuficientes. Sendo assim, o professor e a gestão escolar deve observar as realidades divergentes e adaptar suas práticas metodologias de acordo com as necessidades e possibilidades dos estudantes.

Sendo assim, ao utilizar as tecnologias de informação e comunicação, as diversidades devem ser observadas pela comunidade escolar, gestores e docentes. Assim, a escola e as demais instituições de ensino da atualidade não podem ser indiferentes às diversidades e às possibilidades de uso do computador e principalmente da internet nos processos pedagógicos de ensino.

\section{CONSIDERACÕES FINAIS}

No presente estudo conclui-se que na educação há a adoção de uma postura positiva e interdisciplinar em relação à tecnologia, respeitando as diversidades. Tudo isso é possível com a adoção de novos sentidos para a metodogia docente, respeitando as diversidades e ao mesmo tempo integrando metodologias ativas às atividades educacionais, gestoras e docentes.

Sabemos que pensar a escola na sociedade do conhecimento pressupõe a elaboração de um novo padrão educacional utilizando as tecnologias como metodologias ativas essenciais ao aprendizado do educando. Nesta seleção, as equipes pedagógica e docente devem estar envolvidas no sentido de conduzir esse processo de ensino e aprendizagem para um resultado satisfatório, respeitando as diversidades.

Portanto, a diversificação das sociedades, a comunicação presencial e à distância usando as TICS, a universalização dos Direitos Humanos e a incorporação no meio educacional, requer que o professor e a gestão educacional seja, flexível no sentido de se adequar às realidades sociais existentes. Sendo assim, flexibilizar o currículo em algumas situações é necessária para se adequar às necessidades do aluno, respeitando as suas individualidades e diferenças e possibilitando o avanço na aprendizagem dos alunos. 


\section{REFERÊNCIAS}

ALONSO, M. Gestão escolar: revendo conceitos. São Paulo, PUC-SP, 2004.

ANJOS, Cláudia Giovannetti Pereira dos. O Supremo Tribunal Federal e a proteção às minorias. In: AMARAL JUNIOR, Alberto; JUBILUT, Liliana Lyra. (Org.). O STF e o Direito Internacional dos Direitos Humanos. São Paulo: Quartier Latin, 2009.

BRASIL. Lei de Diretrizes e Bases da Educação Nacional, Brasília, Congresso Nacional, (1996).

BULGARELLI, Reinaldo S. Diversidade cultural. 2008. Disponível em: . Acesso em 20 de setembro de 2015.

CARDOSO, Carlos. Os desafios da diversidade e das novas tecnologias. A página da Educação. Portugal. Disponível em: https://www.apagina.pt/?aba=7\&cat $=107 \& d o c=8565 \& \mathrm{mi} \% 20 \mathrm{~d}=2$. Acesso em: 1 nov. 2021.

CHAUÍ, Marilena. Convite a Filosofia. 12. ed. São Paulo: Ática, 2000.

MOREIRA, Marta, Cândido. Diversidade cultural e formação de professores/as: uma experiência em um assentamento rural. Dissertação de Mestrado em Educação da Universidade de Uberaba, 2004, 186 p.

PESSANHA, M.M de J.; TRINDADE, M.F.B. da; OLIVEIRA, O.A.M. de. A travessia das representações culturais no cotidiano escolar. 2002.

PRATA, CARMEM LÚCIA. Gestão escolar e as tecnologias. In: ALONSO, Myrtes; ALMEIDA, Maria Elizabeth B. de; MASETTO, Marcos Tarciso; MORAN, José Manuel; VIEIRA, Alexandre Thomaz. Formação de gestores escolares para utilização de tecnologias de informação e comunicação. Brasília: Secretaria de Educação a Distância, 2002.

RICOCEUR, Paul. Leituras 1: em torno ao político. Tolerância, intolerância, intolerável. São Paulo: Brasil, 1995. 


\title{
CAPITULO VI
}

\section{A CORTE CONSTITUCIONAL MONOCRÁTICA: QUESTÕES SOBRE AS DECISÕES MONOCRÁTICAS EM CONTROLE DE CONSTITUCIONALIDADE CONCENTRADO}

\author{
DOI: 10.51859/AMPLLA.EDL1037-6
}

\section{Matheus Teodoro ${ }^{1}$}

\begin{abstract}
Graduado em Direito pela FAFIT - Faculdades Integradas de Itararé. Pós-graduado em Advocacia Cível, pela Escola Brasileira de Direito - EBRADI. Pós-graduando em Direito Público, pela Escola Brasileira de Direito - EBRADI; em Direito e Processo Previdenciário, pela Damásio Educacional e em Direito Constitucional, pela Academia Brasileira de Direito Constitucional - ABDConst. Advogado.
\end{abstract}

\section{RESUMO}

É de fácil percepção que, especialmente nas últimas décadas, a quantidade de processos julgados pelo Supremo Tribunal Federal mostra-se crescente, já atingindo números extraordinários, impondo obstáculos para que a Corte cumpra seu papel precípuo, que é a análise e controle de constitucionalidade. Isto se deve a vários fatores, dentre eles as competências excepcionalmente dilatadas do Supremo Tribunal Federal; o sistema de controle de constitucionalidade adotado pelo Brasil, que congloba tanto o modelo concentrado quanto o difuso; a extensão da Constituição, que corrobora com o aumento indireto das competências da Corte Constitucional, entre outros. A fim de proporcionar eficiência aos julgamentos, criou-se a possibilidade de prolação de decisões monocráticas, porém questiona-se a sua legitimidade e respeito à separação dos poderes, mormente quando em ações de controle concentrado de constitucionalidade, uma vez que por decisão liminar, de um único ministro, suspendese o efeito de Lei, processada pelo Legislativo e sancionada pelo Executivo. Assim sendo, é elementar que seja realizada uma análise criteriosa sobre a circunstância aventada, sempre com o objetivo de manter o caráter democrático do Estado, que é reflexo tanto da participação popular em seus atos quanto da necessária separação dos Poderes.

Palavras-chave: Direito Constitucional. Separação dos Poderes. Corte Constitucional. Decisão Monocrática. Ativismo Judicial. 


\section{INTRODUÇÃO}

É notório que o Supremo Tribunal Federal, a Corte Constitucional brasileira, possui um acervo imenso de processos judiciais, demandando grande atividade do órgão judicante. De modo símile, é cediço, em análise comparatória com Cortes Constitucionais internacionais, que a quantidade de processos sob a nossa Pretória Corte encontra-se em números muito superiores à média mundial.

Deste estado de coisas, promanam importantes efeitos sob a sistemática e prática do Supremo Tribunal Federal, como o número gigantesco de lides julgadas por decisões monocráticas, de modo que se questiona tanto a legitimidade destas decisões quanto o caráter colegiado do próprio Tribunal.

Maior relevo possuem as decisões monocráticas proferidas em controle de constitucionalidade concentrado, uma vez que suspendem os efeitos de atos legislativos por entendimento de um único ministro.

De mais a mais, faz-se importante verificar as causas para estes efeitos maléficos e possíveis soluções para que se proporcione tanto uma maior eficácia no julgamento das demandas, quanto apresente maior legitimidade dos posicionamentos jurisprudenciais assentados pela Corte.

\section{A CONSTITUIÇÃO FEDERAL E AS COMPETÊNCIAS DO SUPREMO TRIBUNAL FEDERAL}

O Supremo Tribunal Federal é o órgão mais antigo, como também de cúpula do Judiciário brasileiro. Na toada do que ensina Masson (2016, p. 916), o órgão máximo do Judiciário nacional foi criado em 1808, recebendo o nome de "Casa da Suplicação", criado no período colonial. Já em 1828, recebeu o nome de "Supremo Tribunal de Justiça", passando a obter o nome atual durante o Governo Provisório da República, "sendo que esta nomenclatura foi substituída na Constituição de 1934 por 'Corte Suprema' e foi restaurada na Constituição de 1937" (MASSON, 2016, p. 916).

Considerando que nosso país adotou a forma federada, é natural que exista órgão Judiciário de proporção nacional, localizando-se na esfera da União, de modo que possam ser resolvidas questões de litígios entre os Estados-Membros. Assim sendo, na esteira do que ensina Theodoro Júnior, "o risco é grande de conflitos interpretativos de 
normas que, por imposição constitucional, devem ser iguais para todos, sem distinção do local onde ecloda o litígio e da qualidade do julgador que o deva pacificar" (MORAES, et al, 2018, p. 812).

Dando continuidade, as competências do Supremo Tribunal Federal são amplas, abarcadas no rol fixado pelo artigo 102, da Constituição Federal. De modo breve, compete à Suprema Corte analisar e julgar ações que versem sobre controle de constitucionalidade tanto de leis federais quanto estaduais, em face da Constituição Federal; Julgar as infrações penais comuns de autoridades com foro especial por prerrogativa de função, como Presidente da República, Membros do Congresso Nacional, seus próprios Ministros, entre outros, bem como eventuais Habeas Corpus impetrados por eles; Julgar os litígios entre Estado Estrangeiro e a União, Estado, Distrito Federal ou Território; Julgar a extradição solicitada por Estado estrangeiro, dentre outras competências (MARTINS, 2021, p. 1464-1466).

Agra (2018, p. 598-599) aduz que as competências do Supremo Tribunal Federal se dividem em originária e recursal, que por sua vez se subdividem em ordinária e extraordinária. Conforme ensina o autor, "Competência originária significa que sobre determinadas matérias apenas o Supremo tem a prerrogativa para solucionar o caso".

$\mathrm{Na}$ hipótese recursal ordinária, somente é possível quando advinda por denegação, em instância única, por Tribunais Superiores, em "habeas corpus, mandado de segurança, habeas data e mandado de injunção", como também no caso de crimes políticos. Por outro lado, o recurso pela via extraordinária representa ferramenta jurídica útil em face de "posicionamentos judiciais que contrariem o Texto Magno e que tenham sido decididos em única ou última instância" (AGRA, 2018, p. 599).

Portanto, considerando que as competências outorgadas ao Supremo Tribunal Federal pela Constituição Federal são extensas, deve-se ponderar que a própria Constituição é analítica, não se limitando às proposições jurídicas materialmente constitucionais, mas sim promovendo "detalhamento de certos assuntos constitucionais ou [...] normas que versam sobre temas que não fazem parte das preocupações das teorias da constituição [...] Exemplos: a Constituição brasileira de 1988" (BERNARDES; FERREIRA, 2016, p. 79-80).

Desta forma, imprescindível pontuar que o Supremo Tribunal Federal não age somente como Corte Constitucional, mas sim como Tribunal Recursal, como se verá mais 
detalhadamente em tópico futuro. Esta configuração organizacional possibilita amplo acesso à Corte, de modo que corrobora com o aumento do acervo de lides.

\section{0 TRIBUNAL CONSTITUCIONAL NO MODELO PÁTRIO}

De início, necessário pontuar que a configuração do modelo de Corte Constitucional é fortemente influenciada pelo modo como se dá o controle de constitucionalidade do sistema jurídico em questão.

De um lado, na construção jurídica mundial, tem-se o controle pela via difusa, originado no célebre caso Marbury v. Madison, julgado pela Corte Constitucional Estadunidense, em 1803. Já no Brasil, este modelo foi introduzido no Texto Maior de 1891, que possuía nítida inspiração no modelo Norte Americano (CUNHA JÚNIOR, 2019, p. 119).

O modelo difuso possibilita a realização do controle de constitucionalidade por qualquer órgão do Judiciário, em qualquer instância, sob qualquer lide, mas sempre de forma secundária, ou seja, a avaliação da constitucionalidade não é o objeto principal da demanda, porém, ainda que com caráter acessório, torna-se obstáculo a ser superado. Como ensina Cunha Júnior (2019, p. 119), "à vista deste modelo, o controle de constitucionalidade dos atos ou omissões do poder público é realizado no curso da demanda judicial concreta, e como incidente dela, por qualquer juiz ou tribunal".

De outro lado, o controle pela via concentrada, como o nome sugere, aglutina o controle de constitucionalidade nas mãos de um órgão, ou de um número limitado de órgãos, que possuem como única finalidade realizar esta ponderação. Assim sendo, o objeto das demandas que chegam à sua jurisdição tem como mote justamente o controle de constitucionalidade, não sendo mais mero apêndice de outra demanda. Nas palavras de Zanotti (2017, p. 156), neste modelo "somente o Tribunal era competente para analisar a constitucionalidade das leis, com exclusão de todos os demais magistrados".

Como é cediço, este modelo tem origem europeia, idealizado por Hans Kelsen, tendo como primeiro país adotante a Áustria, em 1920 (ZANOTTI, 2017, p. 156).

Kelsen (2013, p. 19-20) ensina que no modelo Austríaco, predominante na Europa, o sistema jurídico é dividido em Corte Constitucional e Corte Administrativa, de modo que à primeira é dada a competência de realizar o "controle de 
constitucionalidade das leis e atos administrativos individuais - estes últimos desde que sejam determinados diretamente pela Constituição".

Continua destacando que, excepcionalmente, a competência da Corte Constitucional toma para si prerrogativas da Corte Administrativa, que está incumbida do controle da aplicação das leis. São casos em que são tratadas matérias precipuamente políticas. Nas palavras do autor: "fundamentalmente das matérias que, dada sua importância política, estão confiados à Corte Constitucional, particularmente qualificada para trata-las por sua composição de corte política" (KELSEN, 2013, p. 20).

Portanto, evidenciam-se os contornos dos dois sistemas de controle de constitucionalidade preponderantes no sistema jurídico internacional. Contudo, a Constituição Federal pátria adotou ambos os modelos, de modo que, se de um lado apresenta um sistema mais robusto quanto ao controle de constitucionalidade, de outro causa diversos embaraços no sistema, sendo, um deles, a apreciação de tantos processos pela Corte Constitucional, dado que, por uma via ou outra, todas as lides tem grandes possibilidades de se encerrar na Pretória Corte.

\section{AS DECISÕES MONOCRÁTICAS E A LEGITIMIDADE}

Não bastasse a complexidade do sistema de controle de constitucionalidade nacional, a Corte Suprema ainda é dotada de competência recursal, deixando de atuar no modelo concentrado, de matiz europeia, uma vez que também julga demandas como tribunal ordinário. Masson (2016, p. 918) assenta que "para além dessa função, a Constituição Democrática de 1988 ampliou significativamente as competências originárias da Corte, que hoje, surpreendentemente, possui vasta grade de tarefas".

Como bem destaca Agra:

O STF não seguiu os moldes das cortes constitucionais europeias, que têm
suas atividades restritas apenas ao resguardo dos textos constitucionais (os
tribunais constitucionais concentram de forma exclusiva o controle de
constitucionalidade, não existindo o controle difuso, por parte de todos os
órgãos do Judiciário). No Brasil, o STF, além da missão de guardião da
Constituição, desempenha o papel de órgão recursal, funcionando como uma
quarta instância para o Poder Judiciário. Com essa dupla função, o Supremo
não consegue se dedicar exclusivamente à jurisdição constitucional, o que
não o deixa funcionar plenamente na defesa da Lei Maior (AGRA, 2018, p.
597-598).


Isto posto, pode-se notar o exagerado número de casos julgados pela Corte Suprema que, somente no ano de 2020, proferiu 99.569 (noventa e nove mil, quinhentas e sessenta e nove) decisões, sendo 81.356 (oitenta e uma mil, trezentas e cinquenta e seis) decisões monocráticas e "somente" 18.213 (dezoito mil, duzentas e treze) decisões colegiadas. Dentre estas manifestações judiciais, foram 2.021 (duas mil e vinte e uma) decisões em controle concentrado de constitucionalidade, sendo 1.280 (mil, duzentos e oitenta) decisões monocráticas e 272 (duzentos e setenta e duas) decisões monocráticas liminares, conforme estatística fornecida pelo Supremo Tribunal Federal ${ }^{1}$.

Em vista desta deformidade no sistema jurídico, tentou-se limitar o acesso ao Supremo Tribunal Federal, como nota-se no deslocamento de competência ao Superior Tribunal de Justiça, quando houver dos "entes federativos a recusa de cumprimento de execução da lei federal", promovida pela Emenda Constitucional 45/2004 (BULOS, 2014, p. 1319).

Nesta mesma toada, pela EC. 45/2004, foi criada a repercussão geral como requisito de admissibilidade de recurso extraordinário, na tentativa de frear o elevado número de processos que invadia a Corte. Como dispõe Neves:

Percebendo-se com clareza que o Supremo Tribunal Federal tinha se
desvirtuado da função para a qual foi projetado, atuando em demandas de
menor significância, e sendo exorbitante a quantidade de recursos
extraordinários que chegam àquele tribunal, o legislador resolveu criar um
pressuposto de admissibilidade para que o tribunal passe a julgar somente
causas de extrema relevância ou de significativa transcendência (NEVES,
2017, p. 1730).

Entretanto, em que pese as tentativas de conter o desproporcional número de lides julgadas pelo STF, como restou explicitado nos números supratranscritos, ainda se julga em demasia, não resolvendo-se a causa da anomalia.

Assim sendo, é possível notar a adoção de mecanismos para lidar com esta problemática, como o aumento de competências das Turmas, no Supremo Tribunal Federal, em detrimento das competências do Plenário, através da EC. 45/2004. Portanto, processos de extradição, mandados de segurança em face de atos do Tribunal de Contas da União, do Procurador-Geral da República e do Conselho Nacional do

${ }^{1}$ https://transparencia.stf.jus.br/single/?appid=1f9aa2cf-d569-4e98d2aa9dac4e79a69\&sheet=3490ef1ff90e-4b51-9b93b578efd54efd\&theme=simplicity\&opt=currsel\&select=clearall _ - acessado em $28 / 10 / 2021$, às $10 h$. 
Ministério Público, entre outros, passaram a ser da alçada das Turmas e não mais do Plenário, na lição de Fernandes (2017, p. 1191).

Como explicita o autor, "É interessante que nos últimos anos, as duas Turmas do Supremo Tribunal Federal tiveram suas competências ampliadas para processamento e julgamento de classes processuais que antes eram analisadas exclusivamente pelo Plenário da Corte" (FERNANDES, 2017, p. 1191).

Outra ferramenta utilizada para buscar conter este elevado acervo de processos se dá através da prolação de decisões monocráticas, presente na realidade dos Tribunais, porém de maior relevo, tanto para o presente estudo quanto para o cotidiano jurídico, no âmbito do Supremo Tribunal Federal.

Em que pese a possibilidade de prolação de decisão monocrática, conferida pelo artigo 932, do Código de Processo Civil, há que se ponderar o desequilíbrio de poder individual concedido aos Ministros do Supremo Tribunal Federal.

A título de exemplo, o inciso II, do artigo supra referido, concede poder ao relator para apreciar e proferir decisão liminar em lides de competência originária do Tribunal. Nestes termos, considerando ser de competência originária do STF o julgamento de ações de controle concentrado de constitucionalidade, dá-se a prerrogativa de um único ministro, em sede liminar, suspender a aplicação de uma lei, vencedora de todas as etapas do processo legislativo.

Não é sem motivo que tramita no Senado Federal o Projeto de Emenda Constitucional no 08/2021, que dentre outras disposições, busca alterar os artigos 97 e 102, da Constituição Federal, com a finalidade de que seja vedada a prolação de decisão monocrática que suspenda "I- eficácia de lei ou ato normativo com efeitos erga omnes, com ou sem redução de texto, sob pena de nulidade; II- ato do Presidente da República, do Presidente do Senado Federal, do Presidente da Câmara dos Deputados ou do Presidente do Congresso Nacional". Reserva a possibilidade de decidir-se monocraticamente somente no caso de urgência ou com perigo de grave e irreparável dano, nos casos em que a Corte estiver em período de recesso, devendo ser revisto pelo Tribunal em até 30 (trinta) dias após a retomada dos trabalhos, sob pena de perda de eficácia da decisão.

De fato, fere a natureza e razão de existência do próprio Tribunal, que é necessariamente órgão colegiado, o assentamento de tantas decisões de cunho 
monocrático, maculando tanto a estrutura do Judiciário, quanto a legitimidade imprescindível à Corte.

\section{DO CONSTITUCIONALISMO E SEPARAÇÃO DOS PODERES}

Neste estado de coisas, evidencia-se um descalibramento dos poderes concedidos ao Judiciário, especificamente à Corte Constitucional. Em que pese as diversas competências próprias de um Tribunal Constitucional, aliado as outras tantas prerrogativas conferidas que não fazem parte, tradicionalmente, de uma corte com esta característica, permite-se a tomada de decisão monocrática, mesmo que liminar, que contrarie a decisão final de outro Poder, como o Legislativo.

Não se mostra razoável que por uma decisão de cognição sumária, um único ministro do Supremo barre a eficácia de uma produção legal, mormente se considerado que o ato legislativo passou por todo o processo devido, representando produto final da decisão de dois dos Poderes da República, quais sejam, o Legislativo, pela produção legal e o Executivo, pela sanção. Esta sistemática fere a separação dos poderes.

Como ensinam Bernardes e Ferreira (2016, p. 53-54), o constitucionalismo representa um movimento de "grupos sociais, racionalmente ou não, passam a contar com mecanismos de limitação do exercício do poder político. Nessa acepção ampla, configura-se independentemente da existência de normas escritas ou de desenvolvimento teórico".

A ideia de limitação do poder Estatal é antiga, já presente na Grécia Antiga. Como apontam Bernardes e Ferreira (2016, p. 54), os gregos, a partir do conceito de politeia, assentavam a organização estrutural da pólis, "como também racionalizavam o exercício do poder estatal mediante componentes normativos autônomos (nomoi)".

Corroborando com esta posição, Fernandes (2017, p. 304), aduz que as primeiras ideias de separação e limitação dos Poderes já se fazia presente nos escritos de Aristóteles, que se reforçou com Montesquieu, "a fim de manter a autonomia $e$ independência que Ihes são típicas, nascendo daí a famosa teoria dos freios e contrapesos ('checks and balances')".

Portanto, a ideia de limitação dos Poderes Estatais é entendida como o sentido amplo do conceito de constitucionalismo, ao passo que, em sentido estrito, o constitucionalismo é explanado como uma garantia de direitos em face do Estado, com 
gênese no final do séc. XVIII, "que possibilitou aos cidadãos exercerem, com base em constituições escritas, os seus direitos e garantias fundamentais, sem que o Estado Ihes pudesse oprimir pelo uso da força e do arbítrio" (BULOS, 2014, p. 64).

De modo muito suscinto, pode-se pontuar que corolário deste ideal, origina-se o princípio da separação dos poderes, consagrado em nossa Constituição, no seu artigo 2ำ, revestido do caráter de cláusula pétrea, pelo artigo 60, §4으 (FERNANDES, 2017, p. 303).

Assim sendo, não basta que os Poderes sejam separados, mas há necessidade que sejam harmônicos, a fim de que bem desempenhe-se as funções estatais. Como aponta Moraes, "não há, pois, qualquer dúvida da estreita interligação constitucional entre a defesa da separação dos poderes e dos direitos fundamentais como requisito sine qua non para a existência de um Estado democrático de direito" (MORAES, et al, 2018, p. 19).

É fato que atualmente já não se vê a separação dos poderes de forma tão rígida quanto no início desta teorização, especialmente pela evolução do Estado Liberal no qual se iniciou. Assim sendo, atualmente se fala mais, nas palavras de Silva (2005, p. 109), em "colaboração dos poderes", haja vista a necessidade de maior harmonia para que se proporcione o estado de bem-estar social, adotado pela Constituição Contemporânea.

Desta forma, a suspensão erga omnes dos efeitos de uma lei, que possuí presunção de veracidade, por decisão liminar proferida por um único ministro representa claro desequilíbrio tanto na separação quanto na harmonia dos Poderes.

Como bem assenta Silva, o sistema de freios e contrapesos caracteriza a referida harmonia, de modo que:

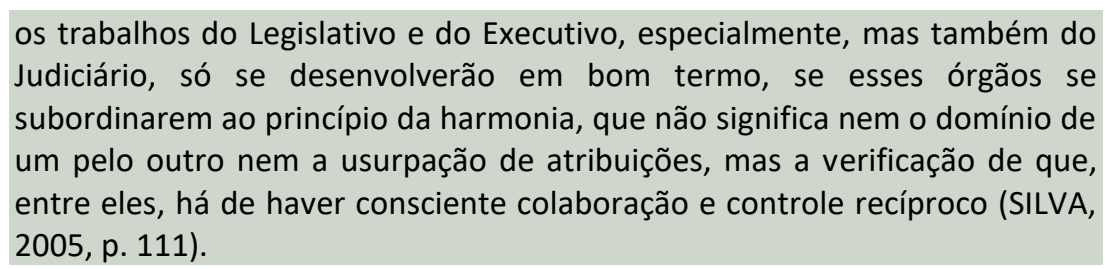

Mais gravoso do que o desbalanço dos Poderes é o próprio ataque à democracia, uma vez que decisões monocráticas nestes termos não são providas de legitimidade bastante para que justifique sua prolação. 
Como se sabe, o Judiciário não se compõe por meio de votação direta, organizando seus quadros através de indicação da Presidência da República com sabatina realizada pelo Senado Federal (MASSON, 2016, p. 917).

Assim sendo, a Corte Constitucional detém legitimidade conferida pela Constituição, bem como, nas palavras de Fux, pela "legitimidade 'contramajoritária'", buscando justificar a revisão exercida pelo judiciário no controle de constitucionalidade, analisando "atos do setor político, investido de representatividade e de legitimidade democrática" (MORAES, et al, 2018, p. 914).

Contudo, ainda que de fato a Constituição Federal conceda a prerrogativa e legitimidade para que o Judiciário exerça tal controle, deve-se ter em mente que esta legitimidade não possui a mesma força do que a advinda do voto popular direto. Com isto, quer-se dizer que os atos que se oponham às leis devem ser sempre vistos com cautela, a fim de que não se exclua o povo do processo democrático, sob pena de expurgar o sustentáculo de uma democracia.

Como aponta Agra (2018, p. 598), para composição da Corte Constitucional, a “indicação dos seus membros, pelas peculiaridades do presidencialismo pátrio, pertence preponderantemente ao presidente, o que faz com que o ministro escolhido não tenha legitimidade social". No mesmo sentido, ensina Fernandes (2017, p. 1188), ao explanar que, embora deva ser sabatinado pelo Senado Federal, o Presidente da República "poderá escolher livremente aquele que entende ser a pessoa adequada para a investidura no cargo".

Logo, a suspensão de um ato normativo, respeitante do devido processo legislativo, revestido de presunção de constitucionalidade, ainda que iuris tantum, não parece ser razoável quando advinda de uma decisão liminar e proferida de forma monocrática. Na prática, um único ministro, alçado ao cargo sem a participação popular direta, suspende os efeitos de uma lei, construída no Legislativo, com a legitimidade proveniente da votação popular. Isto é medida desproporcional.

Evidencia-se, deste modo, que o Texto Maior merece reparo, impossibilitando a tomada de decisão tão impactante por um único ministro, de modo que bem se posiciona o texto da PEC 08/2021, supra referido. 


\title{
6. DA RELAÇÃO DE COMPETÊNCIAS ENTRE O SUPREMO TRIBUNAL FEDERAL E O SUPERIOR TRIBUNAL DE JUSTIÇA
}

A relação entre o Supremo Tribunal Federal e o Superior Tribunal de Justiça é incerta. Como já mencionado, a Corte Constitucional tem dentre suas competências analisar questões constitucionais, tanto de forma originária, no controle de constitucionalidade concentrado, quando de forma recursal, haja vista a possibilidade de interposição de recurso extraordinário (MENDES; BRANCO, 2015, p. 980-983). Ainda, deve-se considerar o extenso rol de competências originárias que não fazem parte da tradicional configuração de uma Corte Constitucional.

De outro lado, atentando-se para algumas das competências do Superior Tribunal de Justiça, como julgar crimes comuns de Governadores, Desembargadores de Tribunais de Justiça e afins, Mandado de Segurança em face de atos praticados por Ministros de Estado, entre outros, destaca-se a função precípua de guardar a uniformidade das leis federais, quando as decisões judiciais de instâncias inferiores contrariarem ou negarem vigência lei federal ou tratado; Julgar válido ato de Governo local em face de lei federal; ou der à lei federal interpretação divergente da concedida por outro Tribunal (MASSON, 2016, p. 943).

Como destacam Mendes e Branco:

\begin{abstract}
A discussão na Constituinte sobre a instituição de uma Corte Constitucional, que deveria ocupar-se, fundamentalmente, do controle de constitucionalidade, acabou por permitir que o Supremo Tribunal Federal não só mantivesse a sua competência tradicional, com algumas restrições, como adquirisse novas e significativas atribuições. A Constituição de 1988 ampliou significativamente a competência originária do Supremo Tribunal Federal, especialmente no que concerne ao controle de constitucionalidade de leis e atos normativos e ao controle da omissão inconstitucional (MENDES; BRANCO, 2015, p. 980-981).
\end{abstract}

Embora a divisão de competências seja bem delineada na construção teórica, na práxis mostra-se o oposto. Isto porque, ainda que o Superior Tribunal de Justiça tenha competência para analisar questões em face de lei federal, como o sistema de controle de constitucionalidade nacional assume a possibilidade tanto da via difusa quanto da via concreta, conjugado ao tratamento prolixo dispensado pela Constituição Federal, é quase impossível que a análise de questão de lei federal não toque pontos constitucionais. 
Como assevera Masson (2016, p. 934), “A competência do Supremo Tribunal Federal que ora se verifica, a de julgar o recurso extraordinário (RE), está intrinsecamente ligada ao exercício de referido controle de constitucionalidade, na via difusa".

Portanto, na prática, o Superior Tribunal de Justiça acaba funcionando como uma espécie de "terceiro grau recursal", ao passo que o Supremo Tribunal Federal assume a função de "quarto grau jurisdicional", o que, evidentemente, provoca distorções maléficas no sistema (AGRA, 2018, p. 597-598).

Na mesma toada de Agra (2018, p. 598), a crítica ao modelo centralizador da Suprema Corte, dada a extensão da Constituição Federal, as inúmeras outras competências que não fazem parte do rol tradicional de uma Corte Constitucional, assim como a forma de escolha dos ministros, "fazem com que o Supremo Tribunal Federal venha recebendo críticas de vários setores da sociedade, que contribuem para o fortalecimento da proposta de transformá-lo em uma Corte Constitucional nos padrões europeus, com adaptações, evidentemente, à nossa realidade social".

De fato, seria melhor equacionada a divisão de funcionalidades do Judiciário se o Supremo Tribunal Federal se mantivesse como Corte Constitucional, concentrada em analisar questões abstratas de constitucionalidade e suas demais competências fossem transferidas ao Superior Tribunal de Justiça.

Se de um lado encerraria o problema de transformar-se o Superior Tribunal de Justiça em somente mais um grau recursal, de outro desafogaria o Supremo Tribunal Federal da quantidade imensa de processos que julga, observando a proporção do número de ministros que o integra.

Cumpre ressaltar que a referida problemática já aflige o STF há muito tempo, de modo que tentou-se amenizar esta distorção com a criação do requisito de repercussão geral para os recursos extraordinário, como aponta Masson (2016, p. 936), ao afirmar que "esse novo modelo tem transformado o recurso em instrumento de defesa da própria ordem constitucional, reforçando o caráter de Corte Constitucional do STF, em detrimento de seu papel de mera instância recursal".

Contudo, não representou solução que tratou eficazmente do problema, dado que ainda persistem os números gigantescos de casos julgados pela Corte Constitucional, como ainda se lança mão, visando dentro outros fatores superar este 
sobrecarregamento, de prolação de decisões monocráticas, até mesmo em casos mais importantes como controle concentrado de constitucionalidade.

\section{CONSIDERAÇÕES FINAIS}

Desta feita, ante todo o exposto, evidencia-se uma problemática no equacionamento das competências do Supremo Tribunal Federal, de modo que o sobrecarrega e não permite que exerça sua função precípua na imensa maioria das lides que julga.

Isto porque, para além do extenso rol de competências que não se configuram como características de uma Corte Constitucional, tem-se que a Constituição Federal é prolixa, atingindo diversos temas que não fazem parte, tradicionalmente, das teorias das Constituições. Aliado a isto, importante pontuar que o sistema jurídico pátrio adotou tanto o controle de constitucionalidade difuso quanto o concentrado, aumentando ainda mais a possibilidade de resolver-se a lide no âmbito da Corte Suprema.

Deste conjugado de fatores resulta-se no imenso acervo e processos jugados ou que aguardam julgamento da Pretória Corte, que se vê impossibilitada de cumprir sua missão constitucional com razoabilidade. Na tentativa de resolver este complexo problema, diversas ferramentas foram utilizadas, como a criação do requisito de repercussão geral; a transferência de competências do Plenário para as Turmas, bem como para o Superior Tribunal de Justiça, ainda que de forma muito contida; e a prolação de decisões monocráticas.

Contudo, o assentamento de decisões monocráticas, especialmente em sede liminar, enfraquecem o Judiciário, seja porque desconsidera o caráter colegiado da Corte, bem como toda a estrutura do judiciário, seja porque a decisão de um único ministro não detém legitimidade bastante para se justificar.

Esta falta de legitimidade popular dos ministros do Supremo Tribunal Federal, justamente por não serem alçados com voto direito do povo e não exercerem o poder por mandatos, ganha contornos ainda mais gravosos quando se tratam de atos jurídicos sobre controle de constitucionalidade concentrado.

Na prática, um único ministro, sem legitimidade popular, suspende de forma monocrática e, muitas vezes, em cognição sumária os efeitos de lei, sagrada vencedora em todo o processo legislativo e sancionada pelo Executivo. É distorção no equilíbrio 
dos poderes que afeta explicitamente a democracia, uma vez que a vontade popular, expressa por seus representantes, é barrada pela decisão de um único ministro, nos termos já expostos.

Portanto, entende-se que o Projeto de Emenda Constitucional 08/2021 representa importante avanço institucional e democrático, ao não permitir a prolação de decisão monocrática em sede de controle concentrado de constitucionalidade, ou em face de decisões emanadas dos Presidentes dos outros Poderes. Aqui vê-se um maior respeito à separação e harmonização dos Poderes, andando bem no caminho de um constitucionalismo sadio.

De outro lado, a fim de que se evite a obstrução do STF pela quantidade de processos, é medida razoável a transferências de suas competências exorbitantes ao Superior Tribunal de Justiça, de modo que se mantenha focado no controle de constitucionalidade concentrado, que é a função de fato de uma Corte Constitucional. Com isto, para além da diminuição da carga de processos, que proporcionaria maior eficiência e qualidade nas decisões promanadas pela Pretória Corte, se encerraria outra deformidade no sistema, que é a transformação do Superior Tribunal de Justiça em mero grau recursal.

\section{REFERÊNCIAS}

AGRA, Walber de Moura. Curso de Direito Constitucional. 9. ed. Belo Horizonte: Fórum, 2018.

BERNARDES, Juliano Taveira; FERREIRA, Olavo Augusto Vianna Alves. Direito Constitucional: Tomo I - Teoria da Constituição. 6a. Ed. Salvador: Editora JusPODIVM, 2016.

BULOS, Uadi Lammêgo. Curso de direito constitucional. 8. rev. e atual. de acordo com a Emenda Constitucional n. 76/2013 - São Paulo: Saraiva, 2014.

CUNHA JÚNIOR, Dirley da. Controle de constitucionalidade: teoria e prática. 10. ed. rev. ampl. e atual. - Salvador: JusPODIVM, 2019.

FERNANDES, Bernardo Gonçalves. Curso de Direito Constitucional. 9. ed. rev. ampl. E atual. - Salvador. JusPODIVM, 2017.

KELSEN, Hans. Jurisdição constitucional. 3a. ed. São Paulo: Editora WMF Martins Fontes, 2013. 
MARTINS, Flávio. Curso de direito constitucional. 5. ed. São Paulo: Saraiva Educação, 2021.

MASSON, Nathalia. Manual de direito constitucional. 4. ed. Rev. Ampl. e. Atual. Salvador: JusPODIVM, 2016.

MENDES, Gilmar Ferreira; BRANCO, Paulo Gustavo Gonet. Curso de Direito Constitucional. 10 a ed. rev. e atual. - São Paulo: Saraiva, 2015.

MORAES, Alexandre de ... [et al]. Constituição federal comentada. 1. ed. Rio de Janeiro: Forense, 2018.

MOTTA FILHO, Sylvio Clemente da. Direito constitucional: teoria, jurisprudência e questões. 26. ed. Rev., atual. e ampl. Rio de Janeiro: Forense; São Paulo: Método, 2016.

NEVES, Daniel Amorim Assumpção. Manual de direito processual civil - Volume único. 9. ed. Salvador: JusPODIVM, 2017.

SILVA, José Afonso da. Curso de Direito Constitucional Positivo. 25ạ. Ed. São Paulo: Malheiros Editores, 2005.

ZANOTTI, Bruno Taufner. Controle de constitucionalidade para concursos. 5. ed. rev. ampl. atual. Salvador: JusPODIVM, 2017. 


\section{CAPITULO VII}

\section{O CONSTITUCIONALISMO ECOLÓGICO BIOCÊNTRICO SOB UMA ANÁLISE SISTEMÁTICA CRÍTICA}

DOI: 10.51859/AMPLLA.EDL1037-7

Matheus Teodoro ${ }^{1}$

${ }^{1}$ Graduado em Direito pela FAFIT - Faculdades Integradas de Itararé. Pós-graduado em Advocacia Cível, pela Escola Brasileira de Direito - EBRADI. Pós-graduando em Direito Público, pela Escola Brasileira de Direito - EBRADI; em Direito e Processo Previdenciário, pela Damásio Educacional e em Direito Constitucional, pela Academia Brasileira de Direito Constitucional - ABDConst. Advogado.

\section{RESUMO}

A relação entre o ser humano e o meio ambiente, especificamente em relação à fauna, é questão recorrente no debate doutrinário, de modo que houve grandes evoluções no arcabouço jurídico pertinente. Se nos primórdios o meio ambiente não representava preocupação para o ser humano, tem-se que no sistema jurídico pátrio hodierno um verdadeiro rol de garantias aos animais, ainda que sob uma visão antropocêntrica do Constitucionalismo Ecológico. Com isto, quer-se dizer que estas garantias não representam direitos à fauna, uma vez que não são sujeitos de direitos, mas sim deveres do ser humano. Nesta toada, há movimento recente na doutrina com a finalidade de propor uma mudança de paradigma, de modo que os animais passem a ser sujeitos de direitos e possam fruir de direitos fundamentais, nos moldes dos direitos garantidos ao ser humano. Portanto, relevantes questões exsurgem deste Constitucionalismo Ecológico Biocêntrico, especialmente se de fato representa avanço ao arcabouço jurídico, bem como se traz efetividade que justifique esta mudança tão profunda e os efeitos que lhes são corolários.

Palavras-chave: Direito Constitucional. Direito Ambiental. Direito dos Animais. Constitucionalismo Ecológico. 


\section{INTRODUÇ̃̃o}

É travado, contemporaneamente, em meio doutrinário um interessante debate sobre os direitos dos animais, com algumas menções também em jurisprudências. Parte da doutrina, ainda que minoritária, entende pela necessidade da mudança do paradigma antropocêntrico do Constitucionalismo Ecológico, para uma visão biocêntrica, estabelecendo, desta forma, que os animais são dotados de capacidade de possuir direitos.

Como se verá, a relação entre o ser humano e o meio ambiente, abarcando a fauna, sofreu transformações no decorrer do tempo, de modo que a ponderação sobre o tema é de grande relevância.

Isto posto, oportunas questões surgem no estudo da problemática, tais como os direitos à vida, saúde e dignidade dos animais em face das atividades agropecuária, científica e de lazer do ser humano. Ainda, de grande relevância que seja realizada uma criteriosa análise se, de fato, a visão biocêntrica proporciona mais vantagens do que embaraços jurídicos, ou seja, se traz a proficuidade pretendida.

\section{DO TRATAMENTO LEGAL DOS ANIMAIS}

A legislação hodierna assenta que "são móveis os bens suscetíveis de movimento próprio, ou de remoção por força alheia, sem alteração da substância ou da destinação econômico-social", como exposto no texto legal constante no artigo 82, do Código Civil.

Assim sendo, sob a égide civilista, o entendimento doutrinário sobre o tema é estável, no sentido de que, consoante estabelece a legislação, os animais se caracterizam como bens semoventes, como apontam Mello (2017, p. 18), Lisboa (2008, p. 86) e Diniz (2014, p. 169) ou, ainda, nas palavras de Tartuce (2017, p. 136), "são enquadrados atualmente como coisas no Direito Privado Brasileiro".

Neste mesmo sentido ensina Agra que:

Os animais domésticos sempre foram concebidos como apêndice ao direito
de propriedade, considerados coisa e, portanto, enquadráveis nas
estipulações do Código Civil. Como consequência, os animais não são
admitidos em juízo como titulares de direitos, não tendo legitimidade para
serem considerados partes no ordenamento jurídico. A posição que
tradicionalmente lhes cabe é o de coisa, pertencente a um dos polos da
demanda (AGRA, 2018, p. 190).


Desta feita, por serem abarcados pelo conceito de coisa no enquadramento da esfera jurídica civilista, os animais não se constituem como sujeitos de direitos, de modo que não possuem, por si mesmos, a segurança oriunda dos direitos garantidos aos seres humanos.

É cediço que a convivência entre o ser humano e os animais é de longa data, de modo que o empenho jurídico conferido ao meio ambiente e, especificamente, aos animais vem evoluindo com o transcurso temporal.

Nesta toada, como ensina Martins (2021, p. 142), são identificáveis três ciclos do denominado Constitucionalismo Ecológico. Segundo o autor, em um primeiro momento as Constituições tratavam da preservação do meio ambiente como um dever do Estado, possuindo índole de norma programática. Assim sendo, por não se tratar de direito da pessoa, mas tão somente um dever do Estado, não havia que se falar em demanda judicial sobre a temática.

Dando continuidade, já no segundo ciclo, a preservação e proteção do meio ambiente "deixa de ser apenas um dever do Estado e passa a ser um direito das pessoas", podendo, inclusive, ser demandado judicialmente. Contudo, ainda na lição de Martins, este segundo período tem visão antropocêntrica, ou seja, delimitando o ser humano como o único sujeito de direito, mantendo, por conseguinte, os animais e a natureza como "objetos de direito" (MARTINS, 2021, p. 143).

Por fim, no terceiro ciclo, alcunhado de Constitucionalismo Ecológico Biocêntrico, os animais e a natureza deixam de ser objetos de direito e passam a ostentar o status de sujeitos de direito, como observável nas Constituições da Bolívia e Equador, por exemplo (MARTINS, 2021, p. 143).

A Constituição Brasileira, de 1988, fixa o trato com o meio ambiente no segundo ciclo, uma vez que estabelece que todos possuem o direito ao meio ambiente equilibrado, sendo "bem de uso comum do povo" (art. 225, caput, da Constituição Federal), ou seja, limitando-se a ser direito exclusivo do ser humano.

\section{DO ANIMAL COMO SUJEITO DE DIREITO}

Embora seja posição minoritária em meio doutrinário, existem posicionamentos favoráveis a mudança de paradigma no trato legal com os animais, de modo que passem a ser considerados como sujeitos de direitos e não mais como res, ou coisa. 
Agra (2018, p. 190), explana que um modo de garantir o status de sujeitos de direito aos "seres irracionais", seria distinguir o "conceito de pessoa do de ser humano". Como defende o doutrinador, o Código Civil de 2002 substituiu o vocábulo "homem" por "pessoa", ao tratar da personalidade e da capacidade, "demonstrando claramente que pessoa natural e ser humano são conceitos independentes".

Com o devido respeito, embora o ilustre doutrinador assim defenda, a interpretação que parece ser mais adequada é a de que a substituição do termo "homem" para "pessoa" seja no sentido de desfazer qualquer ideia de que se refira ao gênero masculino, mas sim à espécie humana em sua totalidade, incluindo, por evidência, o gênero feminino. Desta forma, entender que o termo "pessoa" abarque animais mostra-se irrazoável.

Por outro lado, Martins (2021, p. 700), apresenta defesa mais robusta desta teoria, sustentando que os animais são sujeitos de direitos fundamentais, ensejando sua devida proteção. Ao referir-se a Emenda Constitucional 96/2017, conhecida como a PEC da Vaquejada, afirma padecer de inconstitucionalidade material, dado que " $a$ Emenda Constitucional produziu um desproporcional retrocesso na tutela do direito dos animais, violando a cláusula pétrea dos 'direitos e garantias individuais'".

Martins (2021, p. 706) busca apontar um critério objetivo para a identificação de quais animais devam ser incluídos na caracterização de sujeito de direitos, preferindo o posicionamento de que o animal passível de sofrimento deve ser protegido nestes termos, descartando o critério da capacidade de expressar sentimentos.

Embora elogiável o apreço pela vida e integridade dos animais advinda do eminente professor, a qual se compartilha, discordamos respeitosamente de seu posicionamento doutrinário.

Nada obstante a visão antropocêntrica do Constitucionalismo Ecológico estruture o trato com o meio ambiente como direito e dever do ser humano, não reconhecendo direitos aos animais, não incorre afirmar que estes se vejam destituídos de garantias e proteção. Esta proteção é vista com sinal invertido, ou seja, ainda que não concebida como direito subjetivo dos animais é assentada como dever do ser humano.

Como ensina Tartuce (2017, p. 136), a legislação alemã trata os animais como um terceiro gênero, contando com estatutos próprios. Considerando a ausência desta 
desenvoltura jurídica no âmbito nacional, os animais se mantém sob "regras aplicáveis às coisas, com as necessárias modificações".

Tartuce ainda faz importante reflexão, ao pontuar o fato de:

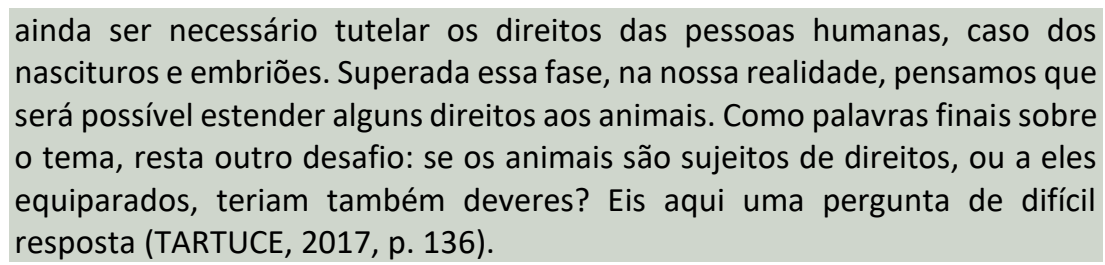

De fato, são vários os imbróglios jurídicos advindos da concessão do estado de sujeito de direito aos animais, afetando vultuosamente a segurança jurídica do ordenamento pátrio. Portanto, tendo em vista não haver necessidade da transformar os animais em sujeitos de direitos para que tenham garantias de sua preservação e que se combata o tratamento cruel, não se mostra medida profícua.

Para melhor explanação sobre o tema, faz-se necessário uma análise atenta em face de alguns pontos cardeais sobre a problemática.

\subsection{DO DIREITO À SAÚDE E QUESTÕES CORRELATAS}

De início, como defendido por Martins (2021, p. 700), determinadas condutas poderiam ferir os "direitos e garantias individuais" dos animais. Assim sendo, destacando-se alguns direitos fundamentais garantidos aos seres humanos e que, neste caso, seriam estendidos aos animais, é possível analisar algumas colocações.

Uma vez estendido aos animais o direito fundamental à saúde, o Estado se veria obrigado, por força do que dispõe o artigo 196, da Constituição Federal, em garantir atendimento médico-veterinário custeado pelo Sistema Único de Saúde - SUS ou por outro sistema símile.

Como ensinam Mendes e Branco (2015, p. 660), o direito à saúde consagrado no Texto Maior possuí tanto aspecto individual quanto coletivo. O seu caráter subjetivo é assegurado "à generalidade das pessoas, que conduz o indivíduo e o Estado a uma relação jurídica obrigacional", porém, pontuando que o direito em comento é exercido através de políticas sociais e econômicas, daí surgindo seu caráter coletivo.

Portanto, não se trata somente de um direito subjetivo e coletivo, mas de verdadeiro dever do Estado em garanti-lo, através de políticas públicas (MENDES; BRANCO, 2015, p. 661). 
Desta forma exsurgem pertinentes questionamentos. A economia nacional suportaria a demanda de fornecimento da imprescindível infraestrutura estatal para assegurar o mencionado direito? De modo símile, referente a mão-de-obra, que seria adquirida através da realização de concursos públicos, teria o Estado condições pecuniárias? Seria necessário um aumento na carga tributária?

Considerando a crise pandêmica vivenciada na atualidade, que somente acentuou as precárias condições de saúde pátria, mostra-se seguro afirmar que o Estado não dispõe de recursos ou estrutura para proteger a saúde do ser humano em sua totalidade, de modo que o sobrecarregar com mais obrigações somente pioraria este cenário.

\subsection{DO DIREITO À LIBERDADE DE LOCOMOÇÃO}

Outra complexa questão sobre a consideração de animais como sujeitos de direito, possuidores de "direitos e garantias fundamentais", reside na liberdade de locomoção.

Conforme planeja orientar o artigo 5ำ, da Declaração Universal dos Direitos dos Animais, da Unesco/1978, o "animal que pertence a uma espécie, que vive habitualmente no ambiente humano, tem o direito de viver e crescer segundo o ritmo e as condições de vida e de liberdade que são próprias da sua espécie".

Fernandes (2017, p. 451-452) destaca que o direito à locomoção se refere ao direito de ir, vir ou permanecer, em tempos de paz, indicando, ainda, que "falar em direito à liberdade de locomoção é muito mais que falar em deslocamento: é pensar no acesso, na permanência, no deslocamento e na saída de um território nacional".

Isto posto, conjugado à hipótese de adoção da visão biocêntrica, a manutenção do animal dentro dos limites das residências das pessoas poderiam configurar infrações à liberdade do animal, segundo artigo 5ㅇ, XV, da CFRB/88. Este posicionamento ganha força quando analisada a distinção entre "pessoa" e "ser humano" realizado por Agra (2018, p. 190), como mencionado no item 2. Desta forma, o conceito de pessoa é independente do de ser humano, podendo ser estendidos aos animais.

Caso for considerada uma violação à livre locomoção do animal, como se daria a responsabilização de eventual dano causado por ele, previsto no artigo 936, do Código Civil, uma vez que "o dono, ou detentor, do animal ressarcirá o dano por este causado, 
se não provar culpa da vítima ou força maior"? Como já destacado por Tartuce (2017, p. 136), se os animais forem detentores de direitos, seriam também possuidores de deveres?

Deste modo, como deverá agir o ser humano, uma vez que ficará entre violar a liberdade de locomoção do animal e, por outro lado, eventual responsabilização de dano por ele causado? Caberia medida judicial movida pelo animal e representado por alguém que detenha capacidade processual para tanto?

Importante pontuar que, conforme supratranscrito, o artigo 5ㅇ, da Declaração Universal dos Direitos dos Animais, da Unesco/1978, é inconfundível ao externar que o animal tem o direito de viver e crescer segundo a liberdade que lhe é própria da espécie.

Estas e outras questões pertinentes levam a concluir que a mudança pretendia pelo Constitucionalismo Ecológico Biocêntrico traz insegurança jurídica, uma vez que cria problemas jurídicos desnecessários.

\subsection{DO DIREITO À VIDA, À DIGNIDADE E DA ATIVIDADE AGROPECUÁRIA}

A mudança de paradigma pretendida propicia complexidade quando entram em conflito o direito à vida e dignidade do animal, sob a visão biocêntrica, e as atividade empreendidas pelo setor agropecuário.

O direito à vida, conforme dispõe Masson (2016, p. 212), possui dupla perspectiva, conglobando tanto o direito de "continuar vivo, ou seja, de não ser morto", quanto o direito de "ter uma vida digna".

Silva (2005, p. 198-199), entende que o direito à vida consiste em "lutar pelo viver, de defender a própria vida, de permanecer vivo". Continua, ainda sob uma visão antropocêntrica, que "agredir o corpo humano é um modo de agredir a vida, pois esta se realiza naquele".

Desta feita, sob o estandarte do biocentrismo, para a "plena interpretação da Constituição Federal, no seu art. 225, exigiria da sociedade a prática do veganismo" (MARTINS, 2021, p. 711).

Ressalta Martins:

No nosso entender, trata-se de uma teoria interessantíssima, que merece reflexão de todos nós. Todavia, entendo que existe, entre a Constituição e os fatos, uma relação bilateral. Se, por um lado, os fatos são influenciados e norteados pela Constituição, esta também decorre dos fatos. Não pode o 
texto constitucional, de inopino, mudar um hábito milenar, ainda que comprovadamente nocivo (MARTINS, 2021, p. 712).

Novamente, com o devido respeito, a posição supra exposta mostra-se contraditória. O eminente jurista defende que "os animais têm o direito de viver dignamente" (MARTINS, 2021, p. 706). Em continuação, assevera-se que:

trouxemos mais indagações que respostas, mas esperamos ter introduzido na
discussão pátria algumas bases para a admissão de uma nova categoria,
geração ou dimensão dos direitos fundamentais. Entendemos que esses
novos direitos devem ser reconhecidos, mas sempre à luz da regra da
proporcionalidade, é claro. Fazemos nossas as conclusões de Cass Sunstein:
"é apropriado considerar o equilíbrio de interesses, e às vezes nossos
interesses superam os de outros animais" (MARTINS, 2021, p. 707).

Ora, a tese sustentada não deixa de ser antropocêntrica, dado que deverá ser garantido direitos aos animais desde que não conflitem com os direitos dos seres humanos. Nesta hipótese, relevantes direitos como a vida e a saúde poderão ser superados, como no caso do abate de 17 (dezessete) milhões de visons, durante a crise da pandemia da Covid-19, por determinação do governo dinamarquês, uma vez que, por alguma espécie de mutação, poderiam transmitir a enfermidade aos seres humanos, como destaca Martins (2021, p. 707).

Aqui não se vê o respeito ao direito da fauna que pretende o biocentrismo, dado que os animais, para a concretização desta visão teórica, deveriam ter sido tratados ou objetos de outra política pública, como ocorreu com seres humanos, posto que o direito em questão era de vida e saúde. Em lugares civilizados, não se matou seres humanos para combater a pandemia da Covid-19.

Portanto, nesta toada, o setor agropecuário se veria, irremediavelmente, fadado à extinção, devendo ser considerado todo o impacto econômico daí advindo, reverberando em toda a sociedade, inclusive em direitos garantidos aos seres humanos.

Vale ressaltar que este tema foi mencionado em uma emenda ao Projeto de Lei $6054 / 2019$, em que se analisa uma mudança promovida pelo Senado Federal, excluindo do tratamento de sujeitos de direitos aos animais, conferido pelo art. 3으, do referido Projeto de Lei, os animais destinados à agropecuária, à pesquisa científica e às manifestações culturais.

Ora, se pretende-se tratar com seriedade a dimensão biocêntrica do Constitucionalismo Ecológico, não há que se falar em diferenciação entre animais destinados à agropecuária, à pesquisa científica ou às manifestações culturais, sob a 
pena de inconstitucionalidade, por violar o princípio da isonomia, assentado no artigo 5ㅇ, caput, da Constituição Federal.

Como ensina Bulos (2014, p. 553), "o princípio da igualdade, isonomia, equiparação ou paridade, consiste em quinhoar os iguais igualmente e os desiguais na medida de sua desigualdade, ensinou Aristóteles". Ainda neste contexto, aduz Silva (2005, p. 215), que a Constituição Federal buscou aproximar a isonomia material e formal, uma vez que não se limita a simples igualdade ante a lei, mas sim atentando-se aos quesitos materiais de desigualdades.

Prosseguindo. Há que se pontuar a necessidade de extinção, na mesma toada das atividades agropecuárias, de zoológicos, bosques e congêneres, para o biocentrismo, uma vez que a exposição e aprisionamento de animais em locais para mero lazer do ser humano, irrefragavelmente, desrespeitariam sua dignidade. Não se vê zoológicos de seres humanos.

Ainda, outra questão subjacente deverá ser ressaltada. O número de determinados animais seria drasticamente reduzido, como por exemplo os bovinos. É evidente que o grande número destes animais se deve às atividades do setor agropecuário, considerando não ser comum sua criação em ambientes domésticos.

Assim sendo, torna-se razoável pontuar que a mudança exigida pelo biocentrismo, neste quadrante da problemática, traria grandes prejuízos econômicos que, inconcussamente, se refletiriam nos direitos garantidos aos seres humanos.

\subsection{DOS DIREITOS DOS ANIMAIS EM FACE DA PESQUISA CIENTÍFICA}

Novamente, mais uma questão extremamente complexa se perfaz quando caracterizados os animais como sujeitos de direitos em face da pesquisa científica. É cediço que diversos avanços da ciência, especialmente no campo medicinal, somente foram passíveis de desenvolvimento seguro quando testados em animais, comumente em ratos.

Neste ponto, Martins (2021, p. 706), assenta posição no sentido de que deverá haver uma ponderação de direitos quando necessária a experimentação de medicamos em animais. Nos termos do autor, "a pesquisa científica realizada em ratos pode ser essencial para a descoberta da cura de doenças importantes e, nesse caso, num juízo de 
ponderação, seu direito seria sacrificado em detrimento de outro direito tido como mais relevante".

Pois bem, como já contextualizado anteriormente, em especial no item 2.3 deste trabalho, esta visão de ponderação mostra-se contraditória e acaba por reforçar o caráter superficial do Constitucionalismo Ecológico Biocêntrico.

Isto porque estariam garantidos direitos aos animais desde que não entrassem em conflitos com direitos dos seres humanos, ou seja, não haveria qualquer garantia efetiva para o direito dos animais. De mais a mais, os direitos em questão são direitos de grande relevância, como vida, saúde e dignidade.

Cumpre ressaltar que o tema também foi objeto de Emenda ao Projeto de Lei 6054/2019, nos mesmos termos já expostos no item supra.

Se há pretensão de uma defesa coerente da teoria sustentada, não se pode falar em ponderação do direito à vida e à saúde do animal em face de experimentos científicos. Certamente não seria permitida a experimentação com humanos. Portanto, se assim procedesse, irrefragavelmente, se estaria atacando direitos fundamentais dos animais, como a vida, saúde e dignidade.

\section{DA PROTEÇÃO À FAUNA}

Ante o exposto, é possível constatar que a visão biocêntrica apresenta diversos obstáculos para sua aplicação, bem como algumas falhas em sua teorização. Entretanto, ainda que a Constituição Federal se mantenha no chamado ciclo antropocêntrico, não se pode dizer que não há proteção ao meio ambiente.

Em verdade, são vários os dispositivos que tratam do tema, estabelecendo o direito ao meio ambiente equilibrado, inclusive com controle sobre edificações e técnicas laborais que representem riscos de danos à natureza, assim como a promoção da educação e conscientização, em todos os níveis de ensino, sobre a preservação do meio ambiente (art. 225, caput e incisos IV, V e VI, da CRFB/88).

A Carta Magna garante a legitimidade para qualquer cidadão propor ação popular que vise anular ato lesivo ao meio ambiente (art. 5o, inciso LXXIII, da CRFB/88). Impõe competência comum à União, ao Distrito Federal, aos Estados e aos Municípios para a proteção ao meio ambiente, assim como a preservação de florestas, fauna e flora (art. 23, incisos VI e VII, da CRFB/88). Confere, ainda, aos entes federados supracitados, 
com exceção dos Municípios, a competência concorrente para legislar sobre a responsabilização por danos ao meio ambiente (art. 24, VIII, da CRFB/88). Assenta que a ordem econômica e financeira deve observar, dentre outros princípios, o da defesa do meio ambiente (art. 170, VI, da CFRB/88). Por fim, para não se alongar nesta exposição, o dever de proteção da fauna e flora, incluindo a proibição de tratamento cruel, encontra-se firmado pelo artigo 225, VII, da CFRB/88. Vejamos:

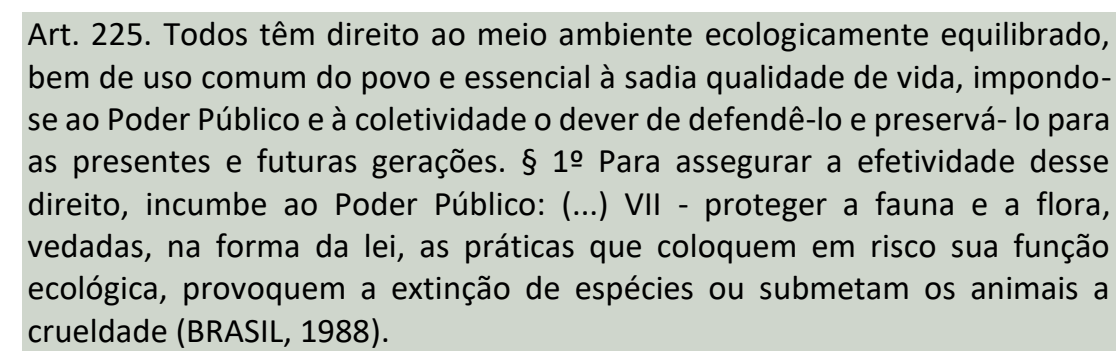

Isto posto, ainda que os animais não sejam considerados sujeitos de direitos em nosso arcabouço legal, resta evidente que a Constituição Federal se dedica extensamente à proteção do meio ambiente, da fauna e flora.

Romeu da Silva (2015, p. 720) ressalta a estruturação infraconstitucional da proteção à fauna, de modo que "todas as infrações ambientais contra a fauna encontram-se compiladas na Lei 9.605/98, que optou por revogar tacitamente os demais crimes contra a fauna previstos em leis esparsas, exceto o crime de pesca de cetáceos previsto na Lei 7.643/87".

Motta Filho (2016, p. 1198-1199) também reforça que o meio ambiente equilibrado integra os direitos fundamentais de terceira geração, discorrendo que " $O$ art. 225, da Constituição, que versa sobre o assunto, afirma que todos têm direito ao meio ambiente ecologicamente equilibrado".

Antunes disserta que "a proibição da crueldade contra animais [...] é, no fundo, a base sobre a qual se apoia o direito ambiental moderno, sendo a própria razão da existência do artigo constitucional" (MORAES, et al, 2018, p. 1521).

Assim sendo, já existe arcabouço jurídico robusto para a proteção dos animais, caracterizado não como um direito dos mesmos, mas como um dever do ser humano. Neste sentido, a título de exemplo, enquadra-se, no artigo 32, da Lei de Crimes Ambientais, a rinha de galos. Como salienta Romeu da Silva (2015, p. 723), uma das condutas abarcadas pela tipificação legal, reside no ato de abuso, que nas palavras do autor traduz-se em "usar mal ou inconvenientemente, como exigir trabalho excessivo do 
animal, ou lançar galo em rinha sabendo que, mesmo vencedor, ele sairá ferido, apenas para satisfazer o desejo dos apostadores".

Neste sentido já há posicionamento jurisprudencial do Supremo Tribunal Federal. Vejamos a emenda do julgado:

AÇÃO DIRETA DE INCONSTITUCIONALIDADE. LEI N. 11.366/00 DO ESTADO DE
SANTA CATARINA. ATO NORMATIVO QUE AUTORIZA E REGULAMENTA A
CRIAÇÃO E A EXPOSIÇÃO DE AVES DE RAÇA E A REALIZAÇÃO DE "BRIGAS DE
GALO". A sujeição da vida animal a experiências de crueldade não é
compatível com a Constituição do Brasil. Precedentes da Corte. Pedido de
declaração de inconstitucionalidade julgado procedente. (ADI 2514,
Relator(a): EROS GRAU, Tribunal Pleno, julgado em 29/06/2005, DJ 09-12-
2005 PP-00004 EMENT VOL-02217-01 PP-00163 LEXSTF v. 27, n. 324, 2005,
42-47) (STF, 2005 - on-line)- Grifo nosso.

Portanto, ainda que com o caráter antropocêntrico no trato com o meio ambiente, não há que se falar desproteção ou falta de normatização do tema.

\section{DA SEGURANÇA JURÍDICA}

É notório que o direito moderno possuí como um de seus mais importantes pilares a segurança jurídica, que passa a valorizar-se com a consolidação do Estado Moderno e a unificação do processo legislativo sob seu cuidado, visando-se, como ensina Bobbio, que o ordenamento jurídico proporcione o "princípio da certeza do direito" (BOBBIO, 1995, p. 207).

Bulos (2014, p. 74) assenta que uma das maiores contribuições do constitucionalismo moderno foi justamente instrumentalizar as diretrizes do Estado e da sociedade em documentos formais, as Constituições, "cujas normas devem integrar um código sistemático e único de todo o seu conteúdo. Disso promana o caráter racionalizador, estabilizante, instrumental e de segurança jurídica das cartas supremas".

Desta feita, o Constitucionalismo Ecológico Biocêntrico acaba por trazer diversas inseguranças jurídicas, das quais algumas foram apontadas neste estudo, impondo pontos desfavoráveis que não justificam sua implantação.

Como mencionado, para que se tratasse o biocentrismo com coerência e seriedade, deveriam ser extintas as atividades agropecuárias e de experimentações científicas em animais. Deveriam ser extintos zoológicos, bosques e similares. O Estado passaria a ser obrigado a custear a saúde dos animais com verbas públicas, inclusive com construção de infraestrutura e fornecimento de mão-de-obra. Surgiriam "hard cases" 
como o conflito entre o direito de locomoção do animal e eventuais danos por eles causados, dentre tantas outras questões que poderiam ser apresentadas.

Entendemos que a adoção desta teoria cria diversos obstáculos e dificuldades no ordenamento jurídico para chegar em um patamar de proteção aos animais que pode ser atingido usando dos meios já estruturados. Obviamente que não se admite tratamento cruel com os animais, porém isto não precisa ser garantido pela via de criação de um novo sujeito de direito, ou seja, não há necessidade de ser um direito do animal, mas um dever, um impedimento, uma vedação ao ser humano.

Do ponto de vista da legitimação do Direito, o biocentrismo também não é bemsucedido. É notável que a produção legislativa, o arcabouço legal, a Constituição são corolários de diversos fatores sociais, especialmente a cultura do povo que a constitui.

Masson (2016, p. 33), defende que "esta acepção desenvolve-se a partir da consideração de que a Constituição é um produto da cultura, pois assim como a cultura é o resultado da atividade criativa humana, o Direito também o é".

A concepção culturalista de Constituição procura alinhar três outros sentidos de Constituição, a saber, o Sociológico, tendo-a como fatores reais de poder, sustentada por Lassalle; a Política, entendida como uma decisão política fundamental, na visão de Carl Schimitt; e na acepção Jurídica, onde trata-se do documento jurídico máximo, orientador de todo o restante da estrutura legal, no magistério de Hans Kelsen (MASSON, 2016, p. 29-31).

Como nos ensina Konrad Hesse (1991, p. 25-27), a força normativa da Constituição não é a única força presente nas interações do Estado, de modo que "o Direito Constitucional deve preservar, modestamente, a consciência dos seus limites". Portanto, fica claro que a Constituição é representação da cultura do povo que a elabora, de modo que possuí força normativa, porém deve convier com os fatos sociais.

Assim sendo, vê-se que o melhor meio para garantir o combate ao tratamento cruel com os animais, bem como incentivar uma convivência harmoniosa com o meio ambiente, é a conscientização popular, ou seja, o entranhamento deste ideal na cultura social.

Hesse, magistralmente, ensina que a ciência do Direito Constitucional possui dupla faceta, sendo tanto ciência normativa quando ciência política. Desta forma, é "condicionada tanto pela grande dependência que seu objeto apresenta em relação à 
realidade político-social, quanto pela falta de uma garantia externa para observância das normas constitucionais" (HESSE, 1991, p. 26).

Portanto, como já vem ocorrendo, as transformações da relação entre seres humanos e animais devem ter gênese na moral popular, ou seja, na realidade social e não ser imposta por lei, considerando que não estará alinhada com a vontade do povo, padecendo tanto de legitimidade quanto de eficácia.

Ademais, como aduz Hesse (1991, p. 27), é dever da Constituição espelhar os valores culturais do povo que buscará orientar, assim como não se pode admitir que integrem o Texto Maior normas que não são passíveis de eficácia, de realização, ou, nas palavras do autor, "nada seria mais perigoso do que permitir o surgimento de ilusões sobre questões fundamentais para a vida do Estado".

Em outro momento, afirma que a Constituição ordena e organiza a realidade político-social, porém deve observar "os limites da força normativa da Constituição" que são resultados da "correlação entre ser (sein) e dever ser (sollen)" (HESSE, 1991, p. 24).

Isto posto, não nos parece estar de acordo com a vontade popular a aceitação de mudanças tão radicais em meio social, como extinção das atividades agropecuárias e adesão obrigatória ao veganismo; custeio, através de tributação, de saúde pública aos animais, considerando a deficiência do Estado no tratamento da saúde do ser humano; a extinção de experimentações de medicamentos em animais, dentre outros requisitos imprescindíveis para que se adota as posições do Constitucionalismo Ecológico Biocêntrico com seriedade e coerência.

\section{CONSIDERAÇÕES FINAIS}

Analisada toda a exposição constante neste estudo, vê-se que o Constitucionalismo Ecológico Biocêntrico, embora com o louvável intento de proteger os animais, proporciona inúmeros embaraços ao sistema legal pátrio, impondo insegurança jurídica.

Ainda, exige, para sua implementação séria e coerente, diversas condutas que contrariam nitidamente a vontade popular, como a adoção forçada do veganismo e extinção das atividades pecuárias; a vedação de experimentação científica em animais; o custeio de saúde pública à fauna entre outras circunstâncias tão ou mais complexas. 
Indubitavelmente, é dever tanto do Estado como do ser humano, proteger e respeitar os animais, considerando que também são seres sencientes, bem como integram o meio ambiente, locus onde se encontra o ser humano.

Nada obstante, não é necessária a adoção da visão biocêntrica para o atingimento deste objetivo, bastando perceber que no Constitucionalismo Ecológico Antropocêntrico, embora atos de preservação como a proibição de tratamento cruel com animais não sejam direitos dos mesmos, mas sim deveres do ser humano, alcançam com razoabilidade este fim.

Em nosso ordenamento jurídico, desde a Carta Magna até disposições infraconstitucionais, há robusto arcabouço protetivo em favor da fauna e, em maior escala, do meio ambiente, inclusive com tipificações de condutas que atentem contra sua integridade.

Em continuidade, é cediço que a lei, seja ela constitucional ou infraconstitucional, deve observar a vontade popular, a cultura social da qual ela emana. Portanto, não é razoável que se adote uma visão legislativa que contrarie a cultura e costume do povo, especialmente quando cause sérios prejuízos aos direitos dos seres humanos, como é o caso do biocentrismo, se adotado de forma coerente com suas próprias posições.

Ademais, a força normativa da Constituição, servindo também para a força legal infraconstitucional, conforme ensina Hesse, não pode inserir em seus escritos visões de mundo inaplicáveis, posto que enfraquece o próprio Direito, causando significativos danos ao convívio social.

Assim sendo, em suma, constata-se que o Constitucionalismo Ecológico Biocêntrico, embora buscando um importante objetivo, que é a defesa dos animais e meio ambiente, não traz a proficuidade necessária para uma mudança tão radical na construção jurídica que exige. Os mesmos fins de respeito e harmonia entre o ser humano e os animais, dentro das possiblidades da sociedade contemporânea, podem ser alcançados com razoável sucesso através da visão antropocêntrica.

\section{REFERÊNCIAS}

AGRA, Walber de Moura. Curso de Direito Constitucional. - 9. ed. Belo Horizonte: Fórum, 2018. 
BOBBIO, Norberto. $O$ positivismo jurídico: lições de filosofia do direito. Compiladas por Nello Morra, tradução e notas por Márcio Pugliese, Edson Bino e Carlos E. Rodrigues. São Paulo: Ícone, 1995.

BRASIL. [Constituição (1988)]. Constituição da República Federativa do Brasil de 1988. Brasília, DF: Presidência da República. Disponível em: http://www.planalto.gov.br/ccivil_03/constituicao/constituicao.htm. Acesso em: $21 / 10 / 2017$.

BULOS, Uadi Lammêgo. Curso de direito constitucional. 8. rev. e atual. de acordo com a Emenda Constitucional n. 76/2013 - São Paulo: Saraiva, 2014.

DINIZ, Maria Helena. Código civil anotado. - 17. ed.- São Paulo: Saraiva, 2014.

FERNANDES, Bernardo Gonçalves. Curso de Direito Constitucional. 9. ed. rev. ampl. E atual. - Salvador. JusPODIVM, 2017.

HESSE, Konrad. A força normativa da constituição. 1. Ed. Porto Alegre: Sergio Antonio Fabris Editor, 1991.

LISBOA, Roberto Senise. Direito civil de A a Z.-Barueri, SP: Manole, 2008.

MARTINS, Flávio. Curso de direito constitucional. 5.ed. - São Paulo: Saraiva Educação, 2021.

MASSON, Nathalia. Manual de direito constitucional. 4. ed. Rev. Ampl. e. Atual. Salvador: JusPODIVM, 2016.

MELLO, Cleyson de Moraes. Direito civil: direito das coisas. - Rio de Janeiro: Maria Augusta Delgado, 2017.

MENDES, Gilmar Ferreira; BRANCO, Paulo Gustavo Gonet. Curso de Direito Constitucional. 10 a ed. rev. e atual. - São Paulo: Saraiva, 2015.

MORAES, Alexandre de ... [et al]. Constituição federal comentada. 1. ed. Rio de Janeiro: Forense, 2018.

MOTTA FILHO, Sylvio Clemente da. Direito constitucional: teoria, jurisprudência e questões. 26. ed. Rev., atual. e ampl. Rio de Janeiro: Forense; São Paulo: Método, 2016.

SILVA, José Afonso da. Curso de Direito Constitucional Positivo. 25ạ. Ed. São Paulo: Malheiros Editores, 2005.

SILVA, Romeu Faria Thomé da. Manual de direito ambiental. 5ạ. ed. Salvador: JusPODIVM, 2015. 
STF. ADI 2514, Relator(a): EROS GRAU, Tribunal Pleno, julgado em 29/06/2005, DJ 0912-2005 PP-00004 EMENT VOL-02217-01 PP-00163 LEXSTF v. 27, n. 324, 2005, 42-47. Disponível em: https://jurisprudencia.stf.jus.br/pages/search/sjur9978/false. Acesso em: 21/10/2021/.

TARTUCE, Flávio. Manual de direito civil: volume único. 7. ed. rev., atual. e ampl. - Rio de Janeiro: Forense; São Paulo: MÉTODO, 2017. 


\title{
CAPITULO VIII
}

\section{O DESMONTE DA POLITICA DE ASSISTÊNCIA SOCIAL DURANTE O GOVERNO BOLSONARO: ANÁLISE DO CONTEXTO ASSISTENCIAL NA PANDEMIA DA COVID-19}

\author{
DOI: 10.51859/AMPLLA.EDL1037-8
}

\author{
Adriana Teotônio Borges ${ }^{1}$ \\ Adenisa da Silva Andrade ${ }^{2}$ \\ Francielly Jacome Gonçalves ${ }^{3}$
}

Este trabalho foi apresentado no evento: www.even3.com.br/Anais/entis2021/360952-O-DESMONTE-DAPOLITICA-DE-ASSISTENCIA-SOCIAL-DURANTE-O-GOVERNO-BOLSONARO---ANALISE-DO-CONTEXTO-DA-PANDEMIA ISBN 978-65-5941-413-0.

\begin{abstract}
${ }^{1}$ Discente especial do Programa de Pós-Graduação em Serviço Social da Universidade Estadual da Paraíba - UEPB. Especialista em Serviço Social, Políticas Públicas e Trabalho Profissional pela Universidade Federal de Campina ${ }^{2}$ Grande - UFCG. Graduada em Serviço Social pela Faculdade de Filosofia, Ciências e Letras de Cajazeiras - FAFIC.

graduada de serviço social, universidade Norte do Paraná Unopar, pós graduação Faculdade Kurios, pós graduação lato sensu em Políticas Públicas e Intervenção Social. Pós graduação em Saúde Pública e Gestão Hospitalar.

${ }^{3}$ Discente especial do Programa de Pós-Graduação em Serviço Social da Universidade Estadual da Paraíba - UEPB. Especialista em Serviço Social, Políticas Públicas e Trabalho Profissional pela Universidade Federal de Campina Grande UFCG. Graduada em Serviço Social pela Universidade Federal de Campina Grande - UFCG.
\end{abstract}

\section{RESUMO}

Frente ao contexto de precarização e sucateamento, e com os desafios impostos pela pandemia da COVID-19 temos um agravamento sobre algumas questões sociais, como o aumento de desemprego, amplia a inserção da população em situação de vulnerabilidade social e extrema pobreza. $\mathrm{O}$ atual contexto que vivenciamos é marcado por fortes ataques aos direitos sociais, somado a ampliação de trabalhos temporários, subcontratação, flexibilização, em que se tem o aumento de trabalhos desprotegidos, invisíveis às Leis trabalhistas. Mediante a isto, este artigo propõe analisar o desmonte das Políticas de Assistência Social durante governo Bolsonaro no contexto da pandemia. Quanto a metodologia, classifica-se como um estudo bibliográfico sustentado em livros, artigos científicos publicados em revistas, teses e dissertações). e o Método de Abordagem utilizado foi o Marxista. Como resultados, é possível destacar um processo de enfraquecimento dos trabalhadores, e empobrecimentos da classe trabalhadora, que são atingidos pela agenda neoliberal, em que são submetidos a trabalho precarizado e flexibilizado.

Palavras-chave: Direito Social. Política de Assistência Social. Pandemia da COVID-19. Questão Social 


\section{INTRODUÇ̃̃o}

No cenário brasileiro as políticas públicas vêm sendo alvo de cortes nos investimentos sociais, somado ao processo de desmonte "dramático e violento" de sucateamento, fragmentação e interrupção nas ações dos serviços socioassistenciais, e consequenteredução dos recursos orçamentários, vivencia-se nos equipamentos os comprometimentos das operacionalizações das ações. no entanto, tem se acentuado principalmente no governo Bolsonaro, que de acordo com (Chauí , 20020, p.1 ), trata se de um governo de "extrema-direita, extremo e fascista".

No atual cenário de sucateamento dos serviços públicos, contrarreformas e redução orçamentária, na qual a política de assistência social tem sido fortemente atacada. Temos como Objetivo Analisar o desmonte da Política de Assistência Social durante governo Bolsonaro no contexto da pandemia. De acordo com o objetivo proposto trata-se de uma pesquisa bibliográfica (sustentadoem livros, artigos científicos publicados em revistas, teses e dissertações e o Método de Abordagem utilizado foi o Marxista.

\section{RESULTADO E DISCUSSÃO}

Com o reconhecimento da Assistência Social como política pública de direito, os modelos preventivos e protetivos ganham centralidade na construção das ações desenvolvidas pelos serviços socioassistenciais. Estes são destinados à superação de situação de vulnerabilidade social decorrente da pobreza ou da falta de acesso a serviços públicos e direitos sociais diante da necessidade de cada membro familiar (BRASIL, 2004).

Dessa forma, são ofertados serviços de proteção social básica e especial, cuja finalidade é desenvolver ações da vigilância socioassistencial buscando prevenir situação de risco social por meio do fortalecimento dos laços afetivos, familiares e comunitários, além de assegurar aqueles com direitos violados a inserção na rede de atendimento garantindo o acesso às seguranças básicas e aos direitos socioassistenciais.

Os serviços comportam dois grandes modelos de proteção social, a proteção social básica e a proteção social especial de média e alta complexidade. A proteção social básica refere-se a um conjunto de serviços, programas, projetos e benefícios que tem 
por finalidade prevenir situações de vulnerabilidades e riscos social e fortalecer vínculos familiares e comunitários. Já a proteção social especial (de média e alta complexidade) compreende um conjunto de serviços, programas e projetos que visa contribuir para a reconstrução de vínculos familiares e comunitáriospara o enfretamento de situações de violação de direitos (BRASIL, 2004).

A desregulamentação das políticas públicas em especial Assistencial Social no cenário contemporâneo está ancorada a filantropia e a benemerência acabam assumindo em ações paliativas, focalizada, assistencialistas, celetistas sem apresença do estado ou de outra maneira trazendo a responsabilidade para a família e para sociedade civil.

Desta maneira, de acordo com Mota (2009) a política neoliberal fomenta o aumento do desemprego estrutural, a fragilização da organização da classe trabalhadora e a retração do Estado no campo social e a valorização da economia.

Couto (2014) afirma que, se por um lado a política de Assistência Social avança no reconhecimento dedireito, traz a questão da pobreza e da desigualdade social para a esfera pública, por outro lado, temos a inserção do Estado de forma contraditório e impactante nas políticas econômica neoliberais. No entanto, "o braço coercivo do Estado é fortalecido para proteger os interesses corporativos e, se necessário, reprimir a dissensão", por sua vez, o Estado enquanto regulador das relações entre interesses institucionalizados das classes e grupos sociais não se omite, mas, transforma as condições de seu exercício, na medida em que aprofunda o fracionamento social e territorial (IAMAMOTO, 2007).

Fica evidente, que o atual cenário das políticas públicas em especial da Assistencial Social é acompanhado de tensões, considerando que "segue na conformação de uma classe, na medida em que se repõem as forças políticas e ideológicas que a engendram, demonstrando seus limites, ao assumir uma política fragmentada, focalizada, profundamente assistencializada" (JUNIOR, 2018, p. 290). A partir dessas características consubstanciada com o molde neoliberal desconfigura os princípios de política social.

O ideário neoliberal ganha espaço principalmente no final da década de 70 e início dos anos 80 no século XX. Já no Brasil a adoção dessas medidas vão ganharfôlego a partir dos anos 90 iniciados com o governo Collor de Mello intensificado comgoverno 
Fenando Henrique Cardoso, dentro os principais ideários podemos destacar a necessidade de privatização da esfera pública a desregulamentação financeira, abertura externa, a flexibilização das relações e condições de trabalho a retração ou diminuição do Estado a reestruturação das políticas sociais (IAMAMOTO, 2007).

Diante das transformações ocorridas com a redução nos gastos públicos, de acordo com lamamoto (2007) os serviços socioassistenciais são fortemente atingidos pelo redirecionamento do "Estado forte capaz de resistir à oposição das maiorias", projeto que visa o aumento da desigualdade social, desregulamentação da força do trabalho, somado a uma desresponsabilização perante as necessidades sociais e o agravamento da "população excluído do círculo da civilização", processo que transforma a vida dos trabalhadores, com o efetivo arrebatamento das políticas públicas e a mercantilizaçãodos serviços, a denominada flexibilização da legislação protetora do trabalho.

Com a provação da "PEC 241/2016" durante o governo Michel Temer promoveuo tão terrível corte nos gastos sociais (Saúde, Educação e Assistência Social) por 20anos sem a negociação junto a classe trabalhadora, expressando seu caráter antidemocrático. A PEC representa os privilégios das elites brasileira, argumentando que a solução para as desigualdades sociais e as injustiças sociais é o crescimentona economia, o que temos na verdade é uma é uma "ofensiva neoliberal aos trabalhadore uma tentativa de abolir as conquistas sociais.

Behring e Boschetti (2007), apontam que a proposta neoliberal compactua com redução salarial, flexibilização, terceirização e a desvalorização dos trabalhadores, permite na quase totalidade ao capital o poder de controlar a mão de obra de acordo com as necessidades. Assim, o Estado desempenha a função de controlar as manifestações da classe operária por meios de política sociais, na qual assumi uma nova roupagem, ajustada as estratégias atuais de acumulação, pautada na lógica financeira.

Podemos visualizar o agravamentos das demandas das políticas sociais, sobretudo na Assistência Social por ser alvo de vários ataques dos governos Federaise especialmente do atual governo Jair Messias Bolsonaro, que pactua com o projeto neoliberal, que de acordo com Montaño e Duriguetto,( 2011, p.193), se desdobram em frentes: a ofensiva contra o trabalho (atingindo as leis e direito trabalhistas) e as lutas 
sindicais e da esquerda as chamadas "restruturação produtiva" e "(contra) reforma do Estado".

Diante desta conjuntura de ofensiva, as chamadas "reestruturação produtiva" e a contrarreforma do Estado são repostas articulada do capital à atual fase, uma ofensiva contra o trabalho, que se configura como uma nova estratégia de hegemônica. Por conseguinte, temos perdas dos direitos sociais, trabalhista e a desarticulação dos sindicatos, contribuindo para o aumento das privatizações das empresas pública, sob contratações, corte nos investimentos sociais que aglutina numa perspectiva de neutralizar a crise econômica.

Desse modo, cabe ao Estado o papel de estabelecer e equilibrar a economia através de políticas fiscais, creditícias e de gastos, realizando investimentos ou inversões reais, atuando nos períodos de crises como estímulos a economia (BEHRING E BOSCHETTI, 2007).

Assim, o projeto neoliberal compactua com redução salarial, flexibilização, terceirização e a desvalorização dos trabalhadores e a privatização, que permite na quase totalidade ao capital o poder de controlar a mão de obra de acordo com as necessidades. Por conseguinte, o Estado desempenha a função de controlar as manifestações da classe operária por meios de política sociais, na qual assumi umanova roupagem, ajustada as estratégias de acumulação, pautada na lógica financeira, temos temos um “Estado mínimo para o social e máximo para o capital” (NETTTO, 2012).

Diante dessa dimensão, os impactos são devastadores para as políticas sociais, não pensada sobre o viés universal, mas condicionalizado na redução dos gastos públicos e no déficit fiscal e para gerar superávit primário; isto é, reduzir os gastos públicos com políticas sociais e contribui para o agravamento das condições de vida da massa da população, aumento do desemprego e das necessidades alusivaas políticas sociais relacionadas à política de transferência de renda.

De acordo com Santos (2012), as diversas expressões da "questão social", se manifestam na vida dos trabalhadores inseridos no mercado de trabalho (formal e/ou informalmente), remete na ausência dos determinantes da saúde tais como, acesso a saneamento básico, habitação, educação, elementos que coopera para a pauperização. Evidente que a interferência das classes sociais e do Estado, resulta em políticas sociais de forma redistributiva, compensatório, além dessas situações hátambém a ampliação 
das desigualdades econômicas e sociais, a radicalização das expressões da questão social, e o não acesso do conjunto da classe trabalhadora aosdireitos provenientes das políticas sociais.

A herança da destruição do aparato social se agrava com o (des)governo do presidente Bolsonaro, que resulta nos cortes dos benefícios socioassistenciais, programa de transferências de renda, limita o exercício dos profissionais que atuam na política de Assistência Social traz como consequência a prática de atendimentos imediatistas e paliativos, sem resolução das demandas, mas o acirramentos dos problemas sociais.

Frente aos cortes promovido pelo Presidente Bolsonaro intensificou os drásticos ataques da política de assistência, que impactam diretamente nos serviços socioassistenciais, sendo notáveis uma significativa retração na Assistência Social, gerando uma política ajustada a lógica conservadora, além de selecionar os mais pobres dos mais pobres, revelando o descompasso do trabalho social e radicalizandoa questão social (MOTA, 2010).Desse modo, os cortes promovidos pelo Estado com as políticas sociaisjustificam-se pela lógica de manter a estabilidade monetária, isto é, considerado necessário realinhar os gastos com a disciplina orçamentária e cria uma taxa natural de desemprego.

Além do corte orçamentaria, disserta a crise sanitária em decorrência da pandemia da COVID-19, acirrando assim os desafios já enfrentados em sua construção, a pandemia que perdura há mais de um ano, acarretando 15.519 .525 casos confirmados até 14/maio de 2021, o Sistema Único de Saúde (SUS) enfrenta um dos seus piores momento oriundo do vírus.A pandemia não apenas ocasionou o acirramento da crise sanitária, sobretudoo processo de "desigualdade social, evidenciada por mais de 12,6 milhões de desempregados em 2019, que, somados aos precarizados e "desalentados", chegoua 32 milhões" (BOSCHETTI E BERING, 2021, p.09)

Deste modo, a pandemia revelou ao país e ao mundo um cenário devastador, que contribui para o aumento da precarização, sucateamento, fragmentação, isto é, os ajusteis fiscais intensifica o aguçamento da "questão social "e a violação dos direitos trabalhistas e o processo do aceleramento do contagio. Por outro lado, o Sistema Único de Saúde (SUS), legalmente universal e descentralizado se agoniza com a falta de recursos. 


\section{CONSIDERAÇ̃̃ES FINAIS}

Que se vislumbra é a ampliação do processo de precarização, sucateamento, fragmentação e desproteção da classe trabalhadora em detrimento aoaprofundamento da questão social em decorrência da pandemia da covid-19, em que se intensifica as ações clientelista, assistencialistas e o estado se exime das suas responsabilidade e chama a sociedade civil e a família para assumirtal responsabilidade.

Assim, vivencia-se um processo de enfraquecimento dos trabalhadores, e empobrecimentos da classe trabalhadora, nos quais são submetidos ao trabalho precarizado, flexibilizado e privatizado.

Neste contexto, o projeto neoliberal visa ampliar o setor privado e assim atingi os serviços públicos nas quais têm suas ações comprometidas, ancorado no viés da seletividade, privatização e burocratização, em que os desprovidos do poder aquisitivos são atingidos pelaideologia neoliberal contemporânea, contribuindo para o aguçamento da questão social

\section{REFERÊNCIAS}

BEHRING, Elaine Rossetti; BOSCHETTI, Ivonete. Política social: fundamentos e história/ São Paulo, Cortez, (Biblioteca Básica de Serviço Social, v.2). 2007.

Boschetti, Elaine Rossetti. Assistência Social na pandemia da covid-19: proteção para quem? Social Assistance in the covid-19 pandemic: protection for whom? Serv. Soc. Soc., São Paulo, n. 140, p. 66-83, jan./abr. 2021.

BRASIL, Política Nacional de Assistência Social- PNAS. Brasília- 2004. Ministério do Desenvolvimento Social e Combate à Fome Secretaria Nacional de Assistência Social.

COUTO, Berenice Rojas [et al]. O Sistema Único de Assistência Social no Brasil: uma realidade em movimento. São Paulo: Cortez, 2010.

CHAUÍ, Marilena. O que é a "nova" ultradireita? Outras Palavras, 2019. Disponível em:https://outraspalavras.net/outrasmidias/marilena-chaui-o-que-e-a-novaultradireita. Acesso em: 01 Fer 2021.

DURIGUETTO, Maria Lúcia e MONTAÑO, Carlos. Estado, Classe e Movimentos sociais. São Paulo: Cortez, 2010. (Biblioteca básica de Serviço Social; v. 5). 
Junior; R. P. F. A "ODISSEIA DO SER SOCIAL": O mundo do trabalho nas produções científicas no Serviço Social brasileiro. 357 F. Tese (doutorado Serviço Social, Direitos Humanos e Questão Social) Universidade Federal de Santa Catarina, Florianópolis/SC, 2018

HARVEY, David. O Neoliberalismo: história e implicações. São Paulo: Edições Loyola,2005.

IAMAMOTO, M.V. Serviço Social em tempo de Capital Fetiche. Capital Financeiro, Trabalho e Questão Social. São Paulo: Cortez, 2015.

IAMAMOTO, Marilda Villela. O Serviço Social na cena contemporânea. In: Serviço Social: Direitos e Competências profissionais. Brasília: CFESS/ABEPSS, 2009.

MOTA, Ana Elisabete. Crise contemporânea e as transformações na produção capitalista. In: Serviço Social: Direitos e Competências profissionais. Brasília: CFESS/ABEPSS, 2009.

MOTA, Ana Elizabeth (org). O mito da assistência social: ensaios sobre Estado, Política e Sociedade. 4 Ed. São Paulo: Cortez, 2010.

NETTO, José Paulo. Crise do capital e consequências societárias. In: Revista ServiçoSocial e Sociedade. n. 111. São Paulo: Cortez Editora, 2012.

SANTOS, J. S. "Questão Social": particularidades no Brasil. São Paulo: Cortez, 2012. Biblioteca Básica de Serviço Social 


\title{
CAPITULO IX
}

\section{IMPROBIDADE ADMINISTRATIVA: SEUS ASPECTOS E SUA DENOTAÇÃO CRÍTICA}

\author{
DOI: 10.51859/AMPLLA.EDL1037-9
}

Débora Benicio Alves ${ }^{1}$

Daniela Novacosque ${ }^{2}$

\begin{abstract}
${ }^{1}$ Especialista em Direito Previdenciário e Trabalhista - URCA
${ }^{2}$ Mestranda em Historicidade dos Direitos Fundamentais. Especialista em Penal, Processo Penal e Criminologia e em Historia do Brasil.
\end{abstract}

\section{RESUMO}

O presente trabalho tem como intensão analisar e esquematizar a questão que caracteriza a Improbidade Administrativa, em conformidade com fatores que vem (ganhando) ganhado espaço com desordens diante da lei. Ao exercício das atividades que são desempenhadas pelos agentes públicos e que levam a constância de razões que atentem contra a integridade, desempenhando ilegalidades com enriquecimento pessoal e violando princípios em beneficio próprio, importunando assim a constitucionalidade da lei de improbidade. De tal modo, aos que praticam atos ímprobos existem medidas repressivas que visam impossibilitar o prosseguimento de praticas que conservam a Administração Pública, em desconformidade com a constitucionalidade, ou seja, quando o agente público desobedece à lei, pode vir a ser responsabilizado civilmente, administrativamente e penalmente, dependendo do grau de abuso ao patrimônio público. A Administração Pública é o alicerce para a concretização de serviços, visando à satisfação da coletividade, e é voltada para assuntos detalhados que tem como objetivo alcançar com perfeição os princípios que norteiam a administração. Aos que causem prejuízos ao erário e ao enriquecimento ilícito, consonante as suas especificidades descritas na lei, consiste em improbidade Administrativa. Os que causam prejuízos ao erário e enriquece ilicitamente se enquadram como agentes causadores da improbidade administrativa. Mediante breve análise do estudo, buscará demonstrar a problematização e soluções para uma formação de agentes públicos leais perante a Administração Pública.

Palavras-chave: Improbidade Administrativa. Crítica. Aspectos Norteadores. 


\section{INTRODUÇÃO}

Considera-se, que desde a colonização, mudanças constantes vêm ocasionando efeitos para uma administração ajustada, no presente a improbidade tem como eixo a Constituição Federal de 1988, e fixada pela Lei Federal no 8.429 de 02 de Junho de 1992 que especifica a Improbidade Administrativa, ao qual objetiva a proteção da lealdade através de punição aos agentes ímprobos, por meio de três principais modalidades: o enriquecimento ilícito no exercício de cargos e funções públicos, bem como os atos causadores de prejuízos ao erário e também os inflacionários aos princípios da Administração Pública.

A improbidade Administrativa refere-se aos atos ilícitos causados pelos agentes públicos e terceiros, que não satisfizeram à lei, rematando-se assim a sofrer com penalidades caracterizadas como crime de responsabilidade, tal comportamento é demostrado pelo regulamento como infidelidade, porém a gestão pública insiste na falta de um principio essencial o da moral, estando relacionado com a sua evolução histórica, onde sempre padeceu com condições desleais devido a várias crises econômicas levando esse pretexto como forma de agir com injustiça.

A moralidade administrativa passou a ser a essência e não a fragrância principal, de modo que o preceito ético troca de valor e sobrevém a ser princípio, troca de caráter discordado pela sociedade e sobrevém a ser um valor jurídico. Nesse contexto, analisase que o valor da moral dentro do corpo social não passa de um principio esquecido fingindo não ter valor jurídico algum. Apesar disso, a moralidade não tem seu conceito legal ou constitucional, mas harmonizar-se com respeito ao cumprimento dos valores morais e dos bons costumes. Por outro lado observa-se outra realidade no cotidiano da Administração Pública perante a moralidade, onde o mau comportamento, as condutas ilícitas, a desonestidade, o desperdícios dos cofres públicos são mais sucessíveis no dia a dia.

Para tanto a transformação de um cenário crítico atual seria a transformação na educação, onde a família e a escola buscariam meios de incluir o menor em programas sociais e meios coercitivos, mostrando a passagem correta, deixando-o convencido do dever no futuro perante a honestidade. 
A lei 8.429/92 traz nos artigos 90 ao 11 acepções dos seus atos tais quais: os atos de improbidade administrativa que importam enriquecimento ilícito, dos atos que causam prejuízo ao erário, e os atos que atentam contra os princípios da administração pública, aos quais esses pontos serão analisados de forma a projetar e buscar solucionar as imperfeições decorrentes dos agentes públicos, que de mau desempenho prejudica o corpo social.

Entretanto, todos os pontos abordados na exposição da introdução serão avaliados para o aperfeiçoamento dos atos de Improbidade Administrativa com explanação ao tema Improbidade Administrativa, conceito, os princípios que regem a Administração Pública, a natureza e os aspectos da Administração Pública e a denotação critica quanto ao instituto da Improbidade Administrativa.

\section{IMPROBIDADE ADMINISTRATIVA}

A Improbidade Administrativa introduziu-se no ordenamento jurídico em 2 de Junho de 1992, por meio da Lei Federal no 8.429, que aponta para as penalidades aplicáveis aos agentes públicos que de forma ilícita se favorece no exercício do seu mandato, entre outras diligencias, que visa proporcionar a sociedade um fundamento jurídico para a punição de administradores desleais, que atuam em desonra a lei ou aos princípios congruentes a Administração Pública.

A Lei 8.429 não trouxe um conceito concreto do que seria Improbidade Administrativa, entretanto, delegam os infratores e esmiúçam os casos em que os agentes públicos arcariam com suas ilegalidades, tais quais os atos de Improbidade Administrativa que importam enriquecimento ilícito, os Atos de Improbidade Administrativa que causam prejuízo ao erário e os Atos de Improbidade Administrativa que atentam Contra os Princípios da Administração Pública, onde será o eixo fundamental desta obra.

Para tanto, existe diferença entre moralidade administrativa e probidade administrativa. Desse modo a probidade administrativa denota que não é suficiente a legalidade formal e limitada, no desempenho administrativo, devendo ser explorado a moralidade com princípios éticos, leais, e de boa-fé, buscando regras que assegurem uma adequada e honrosa Administração Pública, onde a moralidade e a probidade se 
harmonizem para um bom desempenho, visando classificar a ideia de honestidade dentro do âmbito Administrativo.

Nessa mesma perspectiva, doutrinadores sustentam conceitos que contentem essa falta de definição concreta levantando uma compreensão sensata. A princípio Meirelles define que "a questão de bens e interesses qualificados da comunidade no âmbito federal, estadual ou municipal, segundo os preceitos do Direito e da Moral, visando ao bem comum" (MEIREELLES, 2003, p.63).

Na linha de concepção de Di Pietro o dever que a administração tem de fiscalizar seus executores com deveres e poderes de prestação de serviços íntegros.

Em sentido subjetivo, formal ou orgânico, ela designa os entes que exercem
a atividade administrativa; compreende pessoas jurídicas, órgãos e agentes
públicos incumbidos de exercer uma das funções em que se triparte a
atividade estatal: a função administrativa; em sentido objetivo, material ou
funcional, ela designa a natureza da atividade exercida pelos referidos entes;
nesse sentido, a Administração Pública é a própria função administrativa que
incumbe, predominantemente, ao Poder Executivo. (DI PIETRO, 2007, p.45)

É papel, portanto, da administração pública, encarregar os agentes públicos para a prestação dos serviços visando continuamente o interesse da sociedade.

Destarte, Meirelles explana o compromisso do agente em distinguir o melhor para a sociedade, "O agente administrativo, como ser humano dotado da capacidade de atuar, deve, necessariamente, distinguir o Bem do Mal, o honesto do desonesto. E ao atuar não poderá desprezar o elemento ético de sua conduta". (MEIRELLES, 2002, p.87)

No ordenamento jurídico a lei $8.429 / 1992$, supervisiona o comportamento dos agentes públicos e disciplina civilmente, administrativamente ou penalmente os que realizam atos ímprobos, tais descumprimentos acaba por prejudicar o patrimônio público. Nesta acepção, entende Martins Júnior:

Porém, o vício de imoralidade administrativa, para caracterizar improbidade, requer uma especial qualificação do ato e seus efeitos, demonstrativa da inabilitação moral e do desvio ético de conduta do agente público. Improbidade administrativa revela-se quando o agente público rompe o compromisso de obediência aos deveres inerentes à sua função, e essa qualidade é fornecida pelo próprio sistema jurídico através de seus princípios e de suas normas das mais variadas disciplinas. [...] A partir desse comportamento, desejado ou fruto de incúria, desprezo, falta de precaução ou cuidado, revelam-se a nulidade do ato por infringência aos princípios e regras, explícitos ou implícitos, de boa administração e o desvio ético do agente público e do beneficiário ou partícipe, demonstrando a inabilitação moral do primeiro para o exercício de função pública. (MARTINS JÚNIOR, 2006 , p. 105 ). 
Vislumbra buscar a Lei 8429/92 a moralidade administrativa, na qual a violação desta ocasiona transtornos, abalando assim a Administração Pública e afetando todo o corpo social. A falta de reverência na prestação do serviço proporciona desordem e acaba por não cumprir com a ética e a moral, tal incompatibilidade acarreta ao agente ímprobo penalidades postas na lei.

A Lei de improbidade administrativa apresenta instrumentos de amparo para com a moralidade do patrimônio público. Portanto, a moralidade imperou seu entendimento no proceder da ética perante o setor público, de tal maneira a combater à corrupção e punindo os que atuam em prol do interesse individual, onde tal ato propicia prejuízos ao erário e à reputação Administrativa, proporcionando a sociedade atraso no momento em que um improbo age em desonestidade.

Nos últimos tempos, o evidente aumento indisciplinado do erário caracteriza-se pelo favorecimento próprio que provem de desfalques nos cofres públicos, e que causam enormes prejuízos ao patrimônio público. Para tanto a sociedade em que vivemos persevera para progressos, visando à capacidade de uma sociedade justa e saudável, com balanceamento na ética e na economia.

\title{
2.1. NATUREZA JURÍDICA DA ADMINISTRAÇÃO PÚBLICA
}

Salienta-se que se divide em Direito Público e Direito Privado o ordenamento Jurídico Brasileiro. Dessa forma o Direito Público se divide em Interno e Externo. Meirelles assim explana sua percepção acerca do Direito Público e Privado:

\begin{abstract}
O Direito Público Interno visa a regular, precipuamente, os interesses estatais e sociais, cuidando só reflexamente da conduta individual. Reparte-se em Direito Constitucional, Direito Administrativo, Direito Tributário, Direito Penal ou Criminal, Direito Processual ou Judiciário (Civil e Penal), Direito do Trabalho, Direito Eleitoral, Direito Municipal. Esta subdivisão não é estanque, admitindo o despontar de outros ramos, com o envolver da Ciência Jurídica, que enseja, a cada dia, especialização do Direito e a consequente formação de disciplinas autônomas. O Direito Público Externo destina-se a reger as relações entre os Estado Soberanos e as atividades individuais no plano internacional. Já o Direito Privado tutela predominantemente os interesses individuais, de modo a assegurar a coexistência das pessoas em sociedade e a fruição de seus bens, quer nas relações de indivíduo a indivíduo, quer nas relações do indivíduo com o Estado. (MEIRELLES, 1994, p. 26).
\end{abstract}

Para tanto envolve também destacar a ação cognitiva prevista no artigo 17 da lei 8.429/92, designada de ação de improbidade administrativa, cabendo harmonizar-se a tutela processual da probidade administrativa na ação civil pública. 
No entendimento de Neiva sobre o rito da ação destaca-se que:

Registre-se que quanto ao rito a ser adotada para a tramitação da ação,
mesmo no caput do art. 17 ainda mencionar "rito ordinário", cumpre
observar que em razão das modificações introduzidas nos parágrafos do
aludido artigo, pela MP no $2.225-45$, o procedimento adequado para a ação
de improbidade administrativa passou a ser "especial", não mais sendo
obedecido o ordinário. (NEIVA, 2012, p.199)

Deste modo, o nome da ação de improbidade administrativa para Neiva é:

O nome que vai ser dado à ação, não é relevante, o que importa, na verdade,
é saber se a mencionada ação tem natureza coletiva ou não, e se possível à
aplicação dos dispositivos das Leis no $7.347 / 1985$ - Ação ressaltando que o
Superior Tribunal de Justiça vem admitindo o uso da denominada Ação Civil
Pública para repressão da improbidade administrativa. (NEIVA, 2012, p.198)

Diante das abordagens esclarecidas dos autores tem conformidade com o Direito Administrativo uma província do Direito Público, que disponha a atender os interesses sociais com harmonia ao dever probo. Assim, a ação de improbidade administrativa enquadra-se como ação coletiva, e não acarretando apenas os interesses individuais de pessoas indeterminadas integrantes da sociedade, e sim resguardar não somente o patrimônio público, mas também a probidade administrativa que deve ser desempenhada como única forma de busca ao interesse coletivo.

\subsection{OS PRINCÍPIOS QUE REGEM A ADMINISTRAÇÃO PÚBLICA}

Em se tratando de princípios pode-se concluir que se refere ao ponto de partida para uma compreensão. Na ciência jurídica é visto como fonte de estudo e regra de caráter fundamental na tomada de decisões em conflitos de interesses, e tem como conhecimento a base de um direito, e assim forma o ordenamento jurídico em fundamentação dos princípios. Nesse caso, as matérias relacionadas ao direito possuem seus princípios como a Administração Pública.

Os princípios surgem na Administração Pública, com a finalidade de auxiliar a eficiência e o comportamento de seus gestores. De tal forma a se alcançar uma gestão pública honesta, sendo indispensável à compreensão de instrumentos favoráveis para o seu desenvolvimento, tais como os princípios da legalidade, interesse público, eficiência, impessoalidade, onde estes não podem faltar para um bom desempenho da administração Pública.

De acordo com Carvalho filho se define como conceito da administração pública como: Um conjunto de normas e princípios que, visando sempre o interesse público, 
regem as relações jurídicas entre as pessoas e os órgãos do Estado e entre este e as coletividades a que devem servir. (CARVALHO FILHO, 2013, p. 8).

O alicerce da Administração pública constitui suas normas e especialmente em seus princípios, pois são eles que evidenciam as formas coerentes de comportamento para seus gestores. A inadimplência da ética na sociedade é a ausência da realização de seus princípios, que agem como alicerce para uma boa gestão pública. O principio da legalidade, moralidade, impessoalidade e eficiência, são fundamentais para se chegar à ética administrativa.

O artigo 37 da Constituição mostra os princípios norteadores a Administração Pública, apresentados como princípios expressos, tendo como preocupação a disciplina da atuação do Poder Público, de modo a contê-lo, evitando assim, atuações arbitrárias, e norteando a sua atuação no modelo de Estado adotado na atual ordem constitucional.

A Administração Pública seja direta ou indireta, de quais quer dos Poderes da
União, Estados-membros, Distrito Federal ou Municípios, ou seja, de todos os
entes da federação, obedecerá aos princípios da legalidade, impessoalidade,
moralidade, publicidade e eficiência. (BRASIL, 1988, p. 5).

$\mathrm{Na}$ Constituição Federal se encontram os princípios que norteiam o Direito Administrativo, seja de forma implícita, onde se destaca os princípios da supremacia do interesse público sobre o interesse particular e da indisponibilidade do interesse público, ou de forma explícita, onde se encontra a Administração Pública direta e indireta de qualquer dos poderes dos entes públicos devendo obedecer aos princípios da legalidade, da impessoalidade, da moralidade, e da publicidade.

Salienta Celso Antônio Bandeira de Mello que diz:

Violar um princípio é muito mais grave que transgredir uma norma. A
desatenção ao princípio implica ofensa a um específico mandamento
obrigatório, mas a todo o sistema de comandos. É a mais grave forma de
ilegalidade ou inconstitucionalidade, conforme o escalão do princípio
atingido, de seus valores fundamentais, contumélia irremissível o seu
arcabouço lógico e corrosão de sua estrutura mestra. Isto porque, com
ofendê-lo, abatem-se as vigas que o sustém e alui-se toda a estrutura neles
esforçada. (CELSO ANTÔNIO, 2013, p. 620).

A circunstância dos atos de improbidade que violem os princípios da Administração Pública se concretiza na ocorrência do enriquecimento ilícito do agente e de prejuízo ao erário, tendo como aplicação o artigo 11 que deverá incidir em caráter residual, adotando apenas em casos que o ato ímprobo não cause enriquecimento ilícito ou lesão ao patrimônio público. 


\subsubsection{PRINCÍPIO DA LEGALIDADE}

O princípio da legalidade é a base para uma administração eficiente. $\mathrm{Na}$ Administração Pública os seus gestores só podem fazer o que a lei permitir, ou seja, devem agir sempre em concordância jurídica, acatando as normas para progressos do interesse público.

O princípio da legalidade é de suma importância, pois, quando não é desempenhado traz problemas para a sociedade. Por isso, a ética se vincula na realização das normas na sociedade, ou seja, diante do procedimento ético é que o ordenamento jurídico se torna eficaz para a sociedade.

O princípio da legalidade tem referência no caput do artigo 37 da Constituição da República de 1988, determinado por Hely Lopes Meirelles como:

A eficácia de toda atividade administrativa esta condicionada ao atendimento
da lei e do direito. Na Administração Pública não há liberdade nem vontade
pessoal. Enquanto na administração particular é lícito fazer tudo que a lei não
proíbe, na Administração Pública só é permitido fazer o que a lei autoriza. [...]
A legalidade, como princípio de administração, (CF, artigo 37, caput), significa
que o administrador público está, em toda sua atividade funcional, sujeito aos
mandamentos da lei, e às exigências do bem comum, e deles não se pode
afastar ou desviar, sob pena de praticar ato inválido e expor-se à
responsabilidade disciplinar, civil e criminal, conforme o caso. (MEIRELES,
2005, p. 52).

Assim sendo, ao julgar o princípio da legalidade cumpre ressaltar para o fato de que é composta a submissão da Administração para com as leis, devendo obedece-las, cumpri-las e pô-las em praticas. Dessa forma que a atividade de todos os seus agentes serão cumpridas diante das disposições gerais fixadas pelo Poder.

Dentro da Administração Pública submerge um procedimento a ser seguido, ou seja, reverenciar todas as fases de forma satisfatória. Desta forma, quando se começa a administrar a coisa pública, entende-se exclusivamente que a vontade do agente público está subordinada a lei como garantia excepcional, sem violar os direitos e garantias da sociedade, visando ater-se o administrador dentro dos embasamentos jurídicos e nos princípios que a lei determina.

\subsubsection{PRINCIPIO DA IMPESSOALIDADE}

O princípio da impessoalidade é julgado como a atuação do servidor em beneficio da Administração Pública, ou seja, seu encargo no serviço público dizer respeito à coisa pública e não ao agente público. Segundo Fazzio (2007, p. 11), destaca 
que: A impessoalidade decorre diretamente da igualdade, pressuposta a proporcionalidade. Administrar-se impessoalmente, tendo em vista a consecução dos objetivos postos em lei.

Sendo assim este princípio garante a sociedade que o administrador atue de forma impessoal garantindo a forma de governar com igualdade, atuando apenas em prol da coletividade, garantida por lei. Conforme Celso Antônio Bandeira diz que:

\begin{abstract}
No princípio da impessoalidade se traduz a ideia de que a Administração tem que tratar a todos os administrados sem discriminações, benéficas ou detrimentosas. Nem favoritismo nem perseguições são toleráveis. Simpatias ou animosidades pessoais, políticas ou ideológicas não podem interferir na atuação administrativa e muito menos interesses sectários, de facções ou grupos de qualquer espécie. O princípio em causa é senão o próprio princípio da igualdade ou isonomia. (MELLO, 2011, p. 68).
\end{abstract}

Esse princípio é pertinente ao comportamento dos agentes públicos, onde a organização convém para controlar o abuso de poder na Administração Pública.

\title{
2.2.3. PRINCÍPIO DA MORALIDADE
}

Ao que se refere o principio da moralidade tem-se as boas condutas que são submergidas com a Administração pública, esse principio é guiado pela lisura, boa-fé, honestidade, lealdade e a ética.

Sobrevém saber o entendimento da moral ao qual segundo o ordenamento jurídico é ressaltado pelo bem comum, apontando os pareceres legais, sem violar a moral e a ética, conforme Marino Pazzaglini Filho:

\begin{abstract}
A moralidade significa a ética da conduta administrativa; a pauta de valores morais a que a Administração Pública, segundo o corpo social, deve submeter-se para a consecução do interesse coletivo. Nessa pauta de valores insere-se o ideário vigente no grupo social sobre v.g., honestidade, boa conduta, bons costumes, equidade e justiça. Em outras palavras, a decisão do agente público deve atender àquilo que a sociedade, em determinado momento, considera eticamente adequado, moralmente aceito. (PAZZAGLINI FILHO, 1999, p. 60).
\end{abstract}

Ressalta-se também a improbidade ligada à moralidade administrativa e a probidade, Alexandre de Moraes ressalta:

\begin{tabular}{|c|}
\hline $\begin{array}{l}\text { A conduta do administrador público em desrespeito ao princípio da } \\
\text { moralidade administrativa enquadra-se nos denominados atos de } \\
\text { improbidade, previstos pelo artigo } 37 \text {, parágrafo } 4 \text { o, da Constituição Federal, } \\
\text { e sancionada com a suspensão dos direitos políticos, a perda da função } \\
\text { pública, a indisponibilidade dos bens e o ressarcimento ao erário, na forma e } \\
\text { gradação prevista em lei, sem prejuízo da ação penal cabível, permitindo ao }\end{array}$ \\
\hline
\end{tabular}


jurisdicional sobre lesão ou ameaça de lesão ao patrimônio público.

(MORAES, 2008, p. 317).

Portanto, a moralidade administrativa tem sua importância para o desempenho do administrador público, devendo assim prosseguir ao lado da probidade, podendo ser penalizado caso descumpra, sendo responsabilizado civil, administrativa e penalmente.

\title{
2.2.4. PRINCÍPIO DA PUBLICIDADE
}

Compreende-se como princípio da publicidade a divulgação e a comunicação das ações, ou seja, para ter efeitos jurídicos é necessária a publicação, entretanto, a ressalva, pois a Administração Pública zela pelos atos de conteúdos sigilosos. Dessa forma a Administração Pública não pode recusar-se a comunicar um determinado assunto, no entanto tem-se o cuidado a exposição de conteúdos sigilosos.

A publicidade viabiliza as legitimidades, dando ciência à visão de atos legais. Conforme Cardozo:

\begin{abstract}
Entende-se princípio da publicidade, assim, aquele que exige, nas formas admitidas em Direito, e dentro dos limites constitucionalmente estabelecidos, a obrigatória divulgação dos atos da Administração Pública, com o objetivo de permitir seu conhecimento e controle pelos órgãos estatais competentes e por toda a sociedade. (CARDOZO, 1999, p.159).
\end{abstract}

Assim a publicidade visa como finalidade que o serviço público seja o mais transparente possível, dando cabimento para que o cidadão possa participar democraticamente da gestão da coisa pública, principalmente mediante atividade fiscalizatória.

\subsubsection{PRINCÍPIO DA EFICIENNCIA}

Por último o princípio da eficiência trazido pela emenda constitucional no 19/98, ao qual a agilidade e produtividade é o alvo maior onde engloba a celeridade da prestação dos serviços públicos. A visão de Farias sobre esse princípio é:

\footnotetext{
Assim, princípio da eficiência é aquele que impõe à Administração Pública direta e indireta e a seus agentes a persecução do bem comum, por meio do exercício de suas competências de forma imparcial, neutra, transparente, participativa, eficaz, sem burocracia e sempre em busca da qualidade, primando pela adoção dos critérios legais e morais necessários para a melhor utilização possível dos recursos públicos, de maneira a evitarem-se desperdícios e garantir-se maior rentabilidade social. Não se trata da consagração da tecnocracia, muito pelo contrário, o princípio da eficiência dirige-se para a razão e fim maior do Estado, a prestação dos serviços essenciais à população, visando à adoção de todos os meios legais e morais possíveis para satisfação do bem comum. (MORAES, 1999, p.293).
} 
Por isso é evidente que a Administração Pública carece de investimentos na preparação e modernização de seus agentes públicos para disponibilizar condições melhores, buscando o interesse geral da sociedade.

\title{
2.2.6. ANÁLISE FINAL DOS PRINCÍPIOS DA ADMINISTRAÇÃO PÚBLICA
}

Finalizam-se os princípios norteadores da Administração Pública, com a visão para uma caracterização do interesse público, buscando garantir toda a disponibilidade dos agentes públicos, visando o bem comum da sociedade, dessa forma caso o administrador descumpra as condutas postas devidamente, acarretará prejuízos ao todo corpo social e arcará com os seus atos decorrentes ao prejuízo ao erário.

\subsection{ASPECTOS DOS ATOS DA IMPROBIDADE ADMINISTRATIVA QUE CAUSAM PREJUÍZOS AO ERÁRIO E IMPORTAM ENRIQUECIMENTO ILÍCITO.}

O artigo 9 e 10 da lei 8.429/92 denota os atos de Improbidade Administrativa que Causam Prejuízo ao Erário e os Atos de Improbidade Administrativa que Importam Enriquecimento llícito e suas peculiaridades aos que praticam.

Em se tratando de enriquecimento ilícito menciona-se a vantagem patrimonial onde segundo Marcelo Figueiredo ensina que:

\begin{abstract}
Infringe a norma todo agente que obtenha, receba, perceba, direta ou indiretamente, um "interesse" que afronte o padrão jurídico da probidade administrativa, tal como encartada na Constituição Federal e nas leis. Contudo, o legislador não pretendeu esgotar o rol das variadas formas que o enriquecimento ilícito pode assumir. O rol de condutas da lei é exemplificativo. Há outras formas de "obter vantagens patrimoniais indevidas". Assim, o favoritismo, a intenção de privilegiar " $x$ ", " $y$ " ou "z", todas são condutas albergadas na lei. (FIGUEIREDO, 1995, p.38).
\end{abstract}

Já os atos de improbidade administrativa que ocasiona o prejuízo ao erário incidem sobre ações e omissões dolosas ou culposas geradoras de perda patrimonial, que enclausuram a sociedade com prejuízos administrativos e financeiros abandonando o progresso por decorrência da ilicitude do agente.

A lei 8.429/92 traz o artigo 50 onde provém sobre o alvo do legislador em caso de lesão ao patrimônio público, qualificando a punição das condutas dos agentes públicos. Diz o artigo 5o que: “Ocorrendo lesão ao patrimônio público por ação ou omissão, dolosa ou culposa, do agente ou de terceiro, dar-se-á o integral ressarcimento do dano". 
Finaliza-se, percebendo que os atos envolvendo os causadores de prejuízos ao erário e os que importam enriquecimento ilícito, tais atitudes desleais deixam a sociedade sentindo-se censurada e indignada, com tamanha banalidade dentro da Administração e ocasionando danos e prejuízos.

\subsection{DENOTAÇÃO CRÍTICA QUANTO AOS ATOS DA IMPROBIDADE}

Desenvolver a crítica dentro dos atos de Improbidade Administrativa que Importam Enriquecimento Ilícito, Dos Atos de Improbidade Administrativa que Causam Prejuízo ao Erário e por fim Dos Atos de Improbidade Administrativa que Atentam Contra os Princípios da Administração Pública, esse contexto amplia uma serie de avanços levando a crítica para que possa suprir todas as dificuldades que a Administração Pública ocasiona.

\subsection{DOS PRINCÍPIOS}

A improbidade como um todo estabelece, antes, uma imoralidade administrativa. Todavia, nem toda imoralidade conseguirá a posição de improbidade, visto que há distintas condições para concretizar a ilegalidade, sendo, inteiramente possível a passagem de uma eventual imoralidade que não atinja os limites da improbidade, já que esta implica, sobretudo, o caráter da desonestidade.

Assim sendo, a lei que norteia a aplicação da improbidade, exige um elevadíssimo grau de lesividade ao princípio da moralidade administrativa faltando estabelecer a importância de um elemento restritivo à caracterização desses diagnostico funcional. Faltando com respeito à ética e a moralidade que deveria ser primordial aos princípios administrativos.

\subsubsection{OS QUE CAUSAM PREJUIZZOS AO ERÁRIO}

A constatação de uma boa administração não deve ser levada em apreço apenas a subordinação ou não daquilo que estiver menor consagrado em lei, porquanto deve ser levado em conta procedimentos que também envolvam deveres ético-funcionais implícitos. 
condutas eticamente exigíveis dos administradores públicos, tivessem ou não previsão expressa no ordenamento jurídico (HAURIOU, 1938, p. 232).

Deste modo, a deterioração da moral dos agentes públicos e a desmoralização da política estabelecem acontecimentos abundantes que insistem em desobedecer aos valores éticos por cominação ao princípio da moralidade administrativa, devendo-se ajustar as ações dos agentes públicos que exercem.

Para tanto, a crítica da incompetência de agentes públicos é mais um aspecto da má gestão pública. Caso um agente público cometa afronta a ética pública, ainda que obtenha resultados administrativos benéficos, essa conduta deverá ser classificada como "inútil", uma vez que os resultados obtidos serão inevitavelmente contagiados pela imoralidade que reinou no decorrer do procedimento.

\title{
2.4.3. IMPORTAM ENRIQUECIMENTO ILICITO
}

Segundo Sarmento (2002, p. 84), “o enriquecimento ilícito é a manifestação mais expressiva da improbidade administrativa no exercício de cargos públicos". Em concordância com o sua percepção:

[...] o enriquecimento ilícito mantém vários canais de intercomunicação com as demais espécies de improbidade administrativa, pois o locupletamento do agente público implica, invariavelmente, prejuízos ao erário e violação aos princípios da administração pública (SARMENTO, 2002, p.84).

Para o ato de improbidade administrativa se der por concluído necessita que o benefício alcançado pelo agente tenha origem ilícita, decorrente de seu vínculo com a Administração. Desta forma deveria se findar como ato improbo a partir do flagra com a ilegalidade. Salienta Martins Jr. que:

\begin{abstract}
[...] caracteriza o enriquecimento ilícito qualquer ação ou omissão no exercício de função pública para angariar vantagem econômica, ou a potencialidade de satisfação de interesse privado, como também o simples fato do agente público ostentar patrimônio incompatível com a evolução de seu patrimônio ou renda, sendo exigível, em ambos os casos, que a vantagem econômica indevida seja obtida (para o agente público ou terceiro beneficiário, por ele próprio ou por interposta pessoa) em razão de seu vínculo com a Administração Pública, independentemente da causação de dano patrimonial a esta, porque o relevo significativo da repressão do enriquecimento ilícito tem em si considerado preponderância do valor moral da administração pública, sendo direcionado ao desvio ético do agente público (MARTINS JUNIOR, 2010, p. 10).
\end{abstract}

Entretanto, são distintos os argumentos de enriquecimento ilícito da Lei de Improbidade com o enriquecimento sem causa de acordo com o Código Civil Brasileiro, segundo Martins Jr.: 
O enriquecimento ilícito distingue-se do enriquecimento sem causa, porque aquele é repugnado pelo direito por ter uma causa ilícita. A censura legal é endereçada àquele que se aproveita de uma função pública para angariar vantagem econômica a que não faz jus, por qualquer artifício que venha a empregar (MARTINS JUNIOR, 2010, p. 12).

Para o direito privado já é configurado enriquecimento ilícito quando exista uma decaída do sujeito passivo, ao contrario do direito público que para configurar ato de improbidade administrativa este requisito é irrelevante.

\section{CONSIDERAÇÕES FINAIS}

Finaliza-se a abordagem ao tema improbidade administrativa como o dever de administrar e incumbir os agentes para a prestação de serviços a que lhes for denominado para interesse da sociedade. Para tanto, os agentes são aqueles que têm o poder de liberdade para o acesso das atribuições de delegadas decisões cumpridas fielmente, tomando como base os princípios que regem a administração pública.

Aprimorando-se com o tema, o fator principal para se estudar uma problemática na Gestão Pública enseja sobre a determinação de normas que tenham como desígnio evitar a realização dos atos ilegais, ou seja, estabelecer medidas coercitivas mais brandas e contar com a participação dos cidadãos para melhor fiscalização.

Para tanto, se necessita de investimentos que comecem pela educação, buscando medidas educacionais, que garantam aos cidadãos o seus direitos e deveres para com a Administração Pública.

A vista disso é visível que a forma mais sensata de progredir com a participação da sociedade diante da Administração Pública é apresentando medidas benéficas para sua participação, mas também expor medidas coercitivas se caso não cooperar.

Percebeu-se que os princípios tem ampla importância na atividade do administrador público da Administração Pública Direta e Indireta, para todos os entes da federação - União, Estados, Distrito Federal e Município, e que laboram, como um controle funcional da administração.

Dessa maneira teve-se o cuidado de observar a importância do princípio da moralidade administrativa, mostrando seus principais objetivos e a deficiência desse princípio como base da Administração Pública. O princípio da Moralidade Administrativa está ligado à Administração Pública com fundamento nos principais procedimentos tais 
quais irresponsabilidades e má-fé. Deste modo, o ordenamento jurídico pátrio, demostra que essa correlação é consubstanciada pela atividade consistente na defesa concreta do interesse público.

No presente, o país passa por um momento de extrema fragilidade, apontados pelos escândalos que afligem diariamente nossa nação, uma ação de tamanha irresponsabilidade que os gestores e agentes públicos cometem, simplesmente voltados para ambição, deixando de lado a responsabilidade de atuar pelo um país justo e sem pobreza.

\section{REFERÊNCIAS}

CARDOZO, José Eduardo Martins. Princípios Constitucionais da Administração Pública (de acordo com a Emenda Constitucional n. o 19/98). IN MORAES, Alexandre. Os 10 anos da Constituição Federal. São Paulo: Atlas, 1999.

DI PIETRO, Maria Sylvia Zanella, Direito Administrativo, 20ạ edição, São Paulo, Atlas, 20.

BRASIL. Constituição Federal. Brasília: Senado, 1988.

BRASIL. Lei no 8.429. Lei de Improbidade Administrativa. Brasília: Senado, 1992.

FAZZIO Jr., W. Atos de improbidade administrativa: doutrina, legislação e jurisprudência. 2. ed. São Paulo: Atlas, 2008.

FERRAZ JUNIOR, Tércio Sampaio. Possibilidades virtuais da realidade: ontem e hoje. In:

FIGUEIREDO, Marcelo. Probidade Administrativa - Comentários à Lei 8.429/92 e legislação complementar. São Paulo: Malheiros, 1995.

GARCIA, Emerson; ALVES, Rogério Pacheco. Improbidade Administrativa. 4 ed. Rev.Ampl.,Rio de Janeiro: Lumen Juris, 2008.

GASPARINI, Diógenes. Direito Administrativo. 11 edição. Editora Saraiva. São Paulo, 2010.

HAURIOU, Maurice. Précis élementaire de droit administrative. Quatriènne édition. Recueil Sirey, 1938.

MARTINS JÚNIOR, Wallace Paiva. Probidade Administrativa. 3a ed. São Paulo: Saraiva 2010.

MEIRELLES, Hely Lopes. Direito Administrativo Brasileiro. São Paulo: Ed. Malheiros, 2003. 
MELLO, Celso Antônio Bandeira de. Curso de Direito Administrativo. 25ạ edição, São Paulo: Malheiros, 2013.

MORAES, Alexandre de. Direito constitucional administrativo. 4a ed. São Paulo: Atlas, 2011.

NEIVA, José Antonio Lisbôa. Improbidade administrativa. 3ª ed. Niterói: Impetus, 2012.

OSÓRIO, Fábio Medina. Improbidade administrativa: observações sobre a lei 8.429/92. 2a ed. Porto Alegre: Síntese, 2005.

PAZZAGLINI FILHO, Marino; ROSA, Márcio Fernando Elias; JÚNIOR, Waldo Fazzio. Improbidade administrativa - aspectos jurídicos da defesa do patrimônio público. São Paulo: Atlas, 1999.

SARMENTO, G. Improbidade Administrativa. Porto Alegre: Síntese, 2002. 


\title{
CAPITULO $X$
}

\section{BENEFÍCIO ASSISTENCIAL: ANÁLISE DAS CONDIÇÕES DE MISERABILIDADE}

\author{
DOI: 10.51859/AMPLLA.EDL1037-10
}

\author{
Débora Benicio Alves ${ }^{1}$ \\ Carlos Sampaio Peixoto Filho
}

\begin{abstract}
Especialista em Direito Previdenciário e Trabalho - URCA
${ }^{2}$ Mestre em Direito do Trabalho e Relações Internacionais do Trabalho, Professor da Faculdade de Ciências Humanas do Sertão Central.
\end{abstract}

\section{RESUMO}

O presente trabalho tem como objetivo analisar a concessão ao Benefício Assistencial. No artigo 203, V da Constituição Federal de 1988, traz a garantia da concessão de um beneficio assistencial à pessoa idosa ou deficiente que não tenha condições de prover o próprio sustento. Esse benefício tem regulamentação na Lei 8.742/93, conhecida como LOAS - Lei Orgânica da Previdência Social, que demonstra a acerca do benefício de prestação continuada, e institui o direito fundamental à assistência social, garantindo condições de uma sobrevivência digna àqueles que, apesar de não ter vertido contribuições previdenciárias ou tenham perdido a qualidade de segurado, não se encontram em condições de prover o próprio sustento, seja pela idade, ou em razão de alguma deficiência. Entretanto, existem requisitos para sua concessão, dentre eles o critério da miserabilidade, que cita um valor igualitário para definir quem será considerado hipossuficiente para fins do benefício de prestação continuada. Sendo assim, a fixação de um valor baixo para examinar a miserabilidade do postulante, é ferir sem sombra de dúvida esse princípio. Demonstrar-se-á, também, que o Estado não deve se afastar da sua função primordial, qual seja, promover o bem-estar de qualquer pessoa que dele necessite.

Palavras - Chave: Beneficio de Prestação Continuada, Assistência Social, Concessão, Miserabilidade. 


\section{INTRODUÇÃO}

A lei $n$ - 8.742, de 07 de dez. de 1993, alterado pela lei $n=12.435$ de 06 de jul. de 2011 trata do Benefício de Prestação Continuada ou BPC tem como intuito a proteção social, a redução de danos e a prevenção da incidência de riscos, na habilitação e reabilitação das pessoas com deficiência e na promoção de sua integração à vida comunitária, trazendo uma discussão na doutrina a respeito da constitucionalidade no critério para adquirir o benefício.

Por certo, nasciam dúvidas a respeito da constitucionalidade do mencionado fundamento, uma vez que com o avanço e mudanças internas da sociedade e do ambiente jurídico, possuía ampla necessidade de se aplicar de forma flexível, o verdadeiro critério de ser miserável. Tornando como justo, os Juizados, passaram a fazer uso de outros meios para, de fato, avaliar em que ponto o ser humano pode ser avaliado como miserável e logo necessitado da proteção da assistência social.

Deste modo, a Lei Orgânica da Assistência Social - LOAS trata que o critério de miserabilidade esta defasado e, por consequência, inconstitucional, devendo seguir um parâmetro subjetivo para definir o que é ser miserável no Brasil?

Incide, portanto, examinar o alcance da miserabilidade: fazendo a pergunta de como mensurar a hipossuficiência? Tal aspecto é quantia essencial do amparo lançado pela LOAS através do Benefício de Prestação Continuada - BPC, a todos que necessitarem.

No art. 20, inciso III da Lei n. 8.742/93, com entendimento doutrinário e jurisprudencial, determina o que é hipossuficiente e, assim, define a quem se destina o direito ao benefício assistencial.

É necessário apresentar que a problemática ofertada como intrínseca à temática selecionada, se embasa na forma que o benefício LOAS interage com a atual função social e o critério para comprovar a miserabilidade. Nessa concepção, há possível presunção a ser verificada, visando identificar o que de fato pode e deve ser utilizado como parâmetro de pobreza no Brasil, assim como os impactos nos cofres públicos e a constitucionalidade de tal investimento. 
Perante os efeitos expostos, fica evidente a necessidade de fomentar a pesquisa sobre o correspondente tema, tendo em vista à realização de um trabalho esclarecedor do que é de fato ser pobre e a partir de que ponto se inicia a proteção social brasileira.

Por fim, o objetivo geral desse trabalho consiste em contribuir para o desenvolvimento de estudos sobre os benefícios sociais da LOAS aos que dela necessitarem, na garantia de 01 (um) salário-mínimo como benefício mensal à pessoa com deficiência dentro dos parâmetros legais e aos idosos que não possuem meios de prover a própria manutenção ou de tê-la provida por sua família, necessitando por tanto que seja visto este beneficio com olhos humanos o que realmente é critério para miserabilidade para concessão de forma justa e igualitária.

\section{SEGURIDADE SOCIAL}

A Seguridade Social versa sobre um conjunto de políticas públicas, com o fundamento na proteção da sociedade como um todo, visto que é protegida por três vertentes que buscam alcançar a finalidade.

A Constituição Federal de 1988 no caput do art. 194 define a seguridade social como um conjunto integrado de ações de iniciativa dos Poderes Públicos e da sociedade, destinadas a assegurar o direito à saúde, à previdência e à assistência social.

Ao definir seguridade social, a Constituição Federal enumera três programas sociais de maior relevância: a) Saúde; b) Previdência Social; c) Assistência Social.

Tais vertentes descritas sobre a seguridade social estão entrelaçadas umas às outras, visto que, havendo investimento na saúde pública, menos pessoas tendem a ficar doentes, ou o tempo de cura seja reduzido, e em decorrência, um numero reduzido de pessoas necessitarão de benefícios previdenciários.

Então, a proteção social deve procurar a universalidade de seu atendimento, competindo por tanto ao Estado garantir um mínimo de subsistência ao cidadão, que é estimado de acordo com a sua capacidade econômica, dentro do possível, porém sem perder o foco da ordem social.

O art. 196 da Constituição Federal (BRASIL, 1988) expressa o direito à saúde, o qual dispõe: a saúde é direito de todos e dever do Estado, garantindo mediante políticas sociais e econômicas que visem à redução do risco de doenças e de outros agravos, e ao 
acesso universal e igualitário ás ações e serviços para sua promoção, proteção e recuperação.

Sendo assim, para que a finalidade da seguridade social seja alcançada com êxito, faz-se necessário a utilização de maneira eficaz da saúde, a qual está ligada diretamente com o direito à vida, a dignidade humana e ao bem- estar social, que são considerados valores supremos da sociedade brasileira.

A Constituição Federal de 1988 é clara ao constituir que a previdência social precisa ser organizada sob a forma de regime geral, de modo contributivo e de filiação obrigatória, sem deixar de conservar o equilíbrio financeiro e atuarial.

Deve analisar que a previdência social é defendida por dois princípios, são eles a compulsoriedade e a contributividade. O princípio da compulsoriedade, segundo Kertzman (2012), é o que obriga a filiação a regime de previdência social aos trabalhadores que exercem atividade remunerada. E o princípio da contributividade, constitui a necessidade de subsídios ao sistema previdenciário, enquadrando-se na qualidade de segurado, para que caso haja imprevisto, o indivíduo ou sua família não fiquem desapontados.

Nessa seara, outro princípio básico que está inserido na Carta Magna no sistema da seguridade social é o princípio da solidariedade, pois ao recolher contribuições à previdência social, não significa que o segurado usufruirá de seus benefícios em tese. Porém, os recursos destinados à previdência serão encaminhados a quem realmente deles necessitar.

A Constituição de 1988 atribuiu a política pública voltada à assistência social, a qual tem como um dos fundamentos a dignidade da pessoa humana.

É possível definir conforme AMADO a assistência social como:

[...] as medidas públicas (dever estatal) ou privadas a serem prestadas a quem delas necessitar, para o atendimento das necessidades humanas essenciais, de índole não contributiva direta, normalmente funcionando como um complemento ao regime de previdência social, quando este não puder ser aplicado ou se mostrar insuficiente para a consecução da dignidade humana. (AMADO, 2014, p. 50).

A Constituição Federal de 1988 no art. 203 define que a assistência social será prestada a quem dela necessitar, independente de contribuição à seguridade social.

Percebe-se que a assistência social tem particularidades importantes, como a gratuidade, a necessidade, e o objetivo de suprir as necessidades básicas das pessoas. 
Por outro lado é dessemelhante a previdência social, onde a assistência tem caráter não contributivo, não existindo a necessidade de o individuo possuir qualidade de segurado, ter destinado qualquer contribuição financeira para o sistema previdenciário para ser beneficiado.

É importante destacar sobre as prestações assistenciais que são destinadas a garantir às pessoas, sem meios de sustento, condições básicas de vida digna e cidadania, cumprindo também o objetivo constitucional de erradicação da pobreza e da redução de desigualdades sociais e regionais. (SOUZA NETO; SARMENTO, 2010, p. 1.132).

Nessa acepção, o princípio da universalidade, que consiste em atender a todos de maneira universal, não deve ser aplicado de forma integral ao assistencialismo, já que essa assistência não é plena, pois as prestações são direcionadas apenas aos mais pobres.

O Art. 1ํ da Lei 8.742 de 1993 dispõe expressamente acerca das características referidas: A assistência social, direito de todo o cidadão e dever do Estado, é Política de Seguridade Social não contributiva, que provê mínimos sociais, realizadas através de um conjunto integrado de ações de iniciativa pública e da sociedade, para garantir o atendimento às necessidades básicas.

\section{O PRINCÍPIO DA DIGNIDADE DA PESSOA HUMANA}

Do latim se origina a palavra princípio (principium) podendo ter vários significados, dentre eles o inicio de uma a ideia, origem, ponto de partida, ou, ainda, a ideia de verdade, que serve de fundamento, de base para algo.

Neste aspecto, a Constituição Federal de 1988 teve sua preparação fundada em alguns princípios, que serviram para a concepção de um Estado Democrático de Direito, destinado a assegurar o bem-estar social, como também os direitos individuais e coletivos da sociedade.

Para SARLET, dignidade da pessoa humana é:

[...] a qualidade intrínseca e distintiva de cada ser humano que o faz merecedor do mesmo respeito e consideração por parte do Estado e da comunidade, implicando, neste sentido, um complexo de direitos e deveres fundamentais que assegurem a pessoa tanto contra todo e qualquer ato de cunho degradante e desumano, como venham a lhe garantir as condições existenciais mínimas para uma vida saudável, além de propiciar e promover a 
participação ativa e co-responsável nos destinos da própria existência e da vida em comunhão com os demais seres humanos. (SARLET, 2001, p. 62).

Luiz Antônio Rizzatto Nunes (2002, p. 51) alerta que: [...] não pode o Princípio da Dignidade da Pessoa Humana ser desconsiderado em nenhum ato de interpretação, aplicação ou criação de normas jurídicas, de modo que nenhuma interpretação pode acontecer sem a observação desse princípio.

Nesse cenário, a finalidade do princípio da dignidade da pessoa humana é de que todos tenham uma vida digna, e que ninguém seja dominado a padrões inadmissíveis, submetendo-se a condições necessárias para a manutenção básica de sobrevivência.

\title{
4. A ASSISTÊNCIA SOCIAL E O BENEFÍCIO DA PRESTAÇÃO CONTINUADA DE ACORDO COM A LEI ORGÂNICA DA ASSISTÊNCIA SOCIAL - LOAS, SEUS ASPECTOS E AVANÇOS SOCIAIS
}

O benefício continuado ou assistencial chamado de "amparo previdenciário" passou a existir, a partir da necessidade das pessoas, em situação de risco ou de condições de pobreza. Tal benefício tornou-se um avanço no atendimento as deficiências de saúde, desemprego, assistência e amparo familiar, onde não se supria, na razão de apenas $1 / 4$ de salário mínimo. Difere do previsto no art. 203 , inciso $V$ da Constituição Federal, já que uma vez assistencial, independe de contribuição ou filiação, para atender o mínimo necessário.

\subsection{A ASSISTÊNCIA SOCIAL: ASPECTOS E HISTORICIDADE}

Com o surgimento da Assistência Social que resultou na necessidade de proteger as pessoas no âmbito social, e que legitimamente enraizou na pobreza com a falta de direitos básicos essenciais à sobrevida das famílias.

$\mathrm{O}$ art. 203, inciso V da Constituição, menciona a assistência a qual visa garantir à população, independentemente de contribuição.

\begin{abstract}
Art. 203. A assistência social será prestada a quem dela necessitar, independentemente de contribuição à seguridade social, e tem por objetivos:

$\checkmark$ - a garantia de um salário mínimo de benefício mensal à pessoa portadora de deficiência e ao idoso que comprove não possuir meios de prover à própria manutenção ou de tê-la provida por sua família, conforme dispuser a lei.
\end{abstract}

Nesse sentido, houve marcante legislação preconizando leis mediante regras e normas consideradas para a Assistência Social, e com isso ressaltar a Constituição 
Federal em seus artigos 203 e 204 sobre o tema em questão e, através da Lei n. 8.742/93, criada para dar rapidez através da Lei Orgânica da Assistência Social - LOAS, com a contribuição de reintegrar a organização da Assistência Social, em termos de seguridade para toda a coletividade.

\subsection{O BENEFÍCIO DA PRESTAÇÃO CONTINUADA E SUA IMPORTÂNCIA AOS OBJETIVOS ASSISTENCIAIS SOCIAIS}

O Benefício de Prestação Continuada, encontra-se nos artigos 20 e 21 da LOAS.

A lei detalha requisitos do texto constitucional, relacionado com o acesso ao Benefício de Prestação Continuada, são eles: a) a pessoa portadora de deficiência e incapacitada para a vida, independentemente do trabalho; b) o idoso que conte com 65 (sessenta e cinco) anos de idade ou mais; c) a renda mensal per capita da família do requerente, qual seja, inferior a um quarto do salário mínimo vigente; d) e que o requerente não receba qualquer outro benefício da seguridade social ou de outro regime, salvo o de assistência médica.

Portanto, é o preceito do inciso V, do artigo 203 da Constituição Federal, reproduzido também no artigo 20 , I, e, da Lei n. 8.742/93, em termos de garantias de um salário-mínimo de benefício mensal à pessoa com deficiência e ao idoso que comprove não possuir meios de se manter ou de ser provido por sua família.

\section{MISERABILIDADE, BENEFÍCIO DE PRESTAÇÃO CONTINUADA, ART. 20, § 3 DA LEI 8.742/93}

Como mensurar a miserabilidade? Tal aspecto é essencial da proteção lançada pela LOAS, através do Benefício de Prestação Continuada - BPC, a quem necessite, tomando-se como base a lei diante do entendimento doutrinário e jurisprudencial. Assim, o entendimento majoritário sobre o critério estabelecido pelo artigo $20, \S 3$ o da lei acima citada, que define o que é ser hipossuficiente e, portanto, ter direito a adquirir o benefício assistencial. 


\subsection{ASPECTOS DA MISERABILIDADE DEFINIDO PELA LEI ORGÂNICA DE ASSISTÊNCIA SOCIAL}

A questão da miserabilidade estabelecida pela lei 8742 de 1993. O texto constitucional na sua Seção IV trata da Assistência Social, com garantia o valor mensal de 01 salário mínimo às pessoas que portem deficiência física e aos idosos. Contudo, não basta apenas cumprir os requisitos acima. É necessária ainda a demonstração de que não possuir meios de prover à própria manutenção ou de tê-la provida por sua família.

No que diz a carta maior, o benefício de prestação continuada, oferecido através da assistência social, aborda a seguridade social, nos moldes do art. 203, do texto constitucional.

A constituição define a existência do direito. Entretanto, o legislador não tomou partido a se comprometer em descrever quem é idoso. E muito menos se responsabilizou pelo esclarecimento do que é não ter meios de prover a sua manutenção ou de tê-la provida.

De acordo a organização da assistência social, nasceu a Lei n. 8.742 de 1993, onde em seu parágrafo $3^{\circ}$ e artigo 20 , definiu quem é idoso para ser assistido:

Art. 20. O benefício de prestação continuada é a garantia de um salário-
mínimo mensal à pessoa com deficiência e ao idoso com 65 (sessenta e cinco)
anos ou mais, que comprovem não possuir meios de prover a própria
manutenção nem de tê-la provida por sua família.

Portanto, há de se reconhecer, que o benefício é necessário para manter essas pessoas em suas necessidades, em razão da condição e de próprio sustento.

Nesse sentido, importante se questionar como definir uma família que não possui meios de prover a subsistência? A lei deu vida ao § 3 o deste mesmo artigo, onde se considera incapaz de prover a manutenção da pessoa com deficiência ou idosa a família cuja renda mensal per capita seja inferior a 1/4 (um quarto) do salário-mínimo. Mesmo assim, foi necessário que o Decreto 6.214/2007 apresentasse explicações nas formas a realizar o cálculo da renda per capta da família do idoso ou da pessoa com deficiência. Logo, o inciso VI do mesmo dispositivo de lei, com redação dada pelo Decreto $\mathrm{n}$ - 7.617/11, conceitua a renda mensal bruta familiar, assim entendida, como a soma dos rendimentos brutos auferidos mensalmente pelos membros da família, composta por salários, proventos, pensões, benefícios de previdência pública ou 
privada, comissões, pró-labore, outros rendimentos do trabalho não assalariado, rendimentos do mercado informal ou autônomo, rendimentos auferidos do patrimônio, renda mensal vitalícia e o Benefício de Prestação Continuada, ressalvado o disposto no parágrafo único do artigo 19, que esclarece a dúvida da possibilidade de mais de uma concessão no mesmo núcleo familiar.

Neste mesmo sentido encontra-se presente no Estatuto do Idoso que o BPC oferecido a qualquer membro da família não fará parte do cálculo da renda deste grupo. Conforme texto abaixo:

Art. 34. Aos idosos, a partir de 65 (sessenta e cinco) anos, que não possuam
meios para prover sua subsistência, nem de tê-la provida por sua família, é
assegurado o benefício mensal de 1 (um) salário-mínimo, nos termos da Lei
Orgânica da Assistência Social - Loas.

Assim, não basta alcançar o requisito idade. É de suma importância que não haja possibilidade de prover o mínimo necessário existencial ou de tê-lo provido pelos membros da família. Além do mais, o valor de um salário mínimo não será extrapolado com os graus de dificuldade financeira.

Vale ressaltar que o parágrafo único do citado artigo preconiza o benefício já concedido a qualquer membro da família, nos termos do caput não será computado para os fins do cálculo da renda familiar per capita a que se refere a LOAS.

\subsection{MISERABILIDADE: ENQUADRAMENTO, GRUPO FAMILIAR E RENDA}

Ser enquadrado no critério da miserabilidade retrata ao país uma realidade social. Um tema deliberado pela Lei Orgânica da Assistência Social - LOAS, que destaca como espécies àquelas pessoas ligadas ao grupo familiar, sejam elas, o próprio requerente nessa condição, o cônjuge, companheiro, o filho não emancipado em qualquer condição, menor de 21 anos ou inválido, pais, e irmãos não emancipados, menores de 21 anos e inválidos, além do enteado e o menor tutelado, equiparando-se ao filho mediante próprio sustento e educação. São esses critérios que serão computados para o cálculo da renda per capta familiar, servindo de renda a todos da família, o salário, o benefício previdenciário e a pensão alimentícia.

Nesse quesito acima descrito, o benefício não pode ser acumulado com qualquer outro no âmbito da Seguridade Social, ressalvados os casos de assistência médica e 
pensão de natureza indenizatória pela natureza a ser considerada somente àquelas pessoas classificadas na condição de máxima pobreza ou de miserabilidade. E nessas condições, o único critério específico é de que a renda não pode ser inferior a $1 / 4$ do salário mínimo, segundo as normas constituídas em concordância com o texto constitucional.

\section{UMA ANÁLISE AO ART. 20, § 3 DA LOAS: CRITÉRIO OBJETIVO PARA A MISERABILIDADE}

O art. 20 da lei principal em questão dispõe que o benefício de prestação continuada tem como segurança a concessão de benefício mensal à pessoa com deficiência e ao idoso com 65 (sessenta e cinco) anos ou mais, que demonstre não possuir meios de prover seu próprio sustento. Contudo, o parágrafo 3으 da LOAS, adentra no ordenamento jurídico como o principal parâmetro para a concessão ou não do benefício continuado à pessoa incapaz, cuja renda mensal per capita seja inferior a 1/4 (um quarto) do salário-mínimo vigente.

Nessa linha de pensamento opina SANTOS, sobre o parágrafo 3, do artigo 20, da LOAS ao comentar que é manifestamente inconstitucional. Vejamos o que versa suas lições:

\footnotetext{
Não se pode perder de vista que o BPC é aquela parcela de proteção social que se consubstancia em benefício. E a CF quer que esse benefício seja a garantia da manutenção da pessoa com deficiência ou idosa que não tenha ninguém por si. E o fixou em um salário mínimo. O bem-estar social está qualificado e quantificado na CF: qualificado porque se efetiva com a implementação dos direitos sociais; quantificado porque a CF fixou em um salário mínimo a remuneração mínima e o valor dos benefícios previdenciários, demonstrando que ninguém pode ter seu sustento provido com valor inferior.

Ao fixar em $1 / 4$ do salário mínimo o fato discriminante para a aferição da necessidade, o legislador elegeu discrimen inconstitucional porque deu aos necessitados conceito diferente de bem-estar social, presumindo que a renda per capita superior a $1 / 4$ do mínimo seria a necessária e suficiente para a sua manutenção, ou seja, quanto menos têm, menos precisam ter!

Quantificar o bem-estar social em valor inferior ao salário mínimo é o mesmo que "voltar para trás" em termos de direitos sociais. A ordem jurídica constitucional e infraconstitucional não pode "voltar para trás" em termos de direitos fundamentais, sob pena de ofensa ao princípio do não retrocesso social [...].(SANTOS, 2011, p.28)
} 
Verifica-se que ao selecionar a renda per capita mensal familiar de $1 / 4$ (um quarto) do salário mínimo para se avaliar a miserabilidade de uma pessoa, o legislador infringiu o texto constitucional, no tocante ao que quantificou o bem-estar social diversamente do instituído pela lei, ferindo o aludido princípio do não retrocesso social.

A ampla divergência acerca da condição para a obtenção do Benefício advém em virtude de se discutir ou não a possibilidade e flexibilidade da Lei n. 8.742/93 - LOAS, em relação ao requisito da miserabilidade, isto é saber se pode comprovar que uma pessoa em estado de necessidade, com renda per capita familiar superior a $1 / 4$ (um quarto) do salário mínimo, tem a garantia de ser beneficiário de Prestação Continuada.

\subsection{O BENEFÍ́CIO DE PRESTAÇÃO CONTINUADA PARA O DEFICIENTE E IDOSO}

Um conceito que se faz para o deficiente ter direito ao referido benefício, ainda é bastante discutido na doutrina e jurisprudência atuante, em razão de ter que se atestar a real incapacidade do beneficiário, que deve ser permanente ou temporária, e se de forma cumulativa ou alternativa.

A edição da LOAS com a inclusão do § 3ㅇ do art. 21 da Lei 8.742/93, e pela Lei n.12.435/2011, estabeleceram desenvolvimento de capacidades, realização de atividades, habilitação, reabilitação, não constituindo algum motivo para suspensão ou cessação do benéfico com relação às pessoas deficientes ou idosas, conforme o regulamento e mudanças significativas trazidas pela Lei Orgânica da Assistência Social.

\section{JULGADOS DE TRIBUNAIS SUPERIORES DECIDINDO SOB A ÉGIDE JURISPRUDENCIAL E O QUE PRECEITUA A LOAS E A CONSTITUIÇÃO FEDERAL EM SEDE DE BENEFÍCIO DE PRESTAÇÃO CONTINUADA ATENDENDO DIREITOS SOCIAIS}

O INSS (Instituto Nacional do Seguro Social) foi motivado ao ajuizamento de ações no Supremo Tribunal Federal e a decisões diferentes acerca do Benefício de Prestação Continuada nas suas mais diversas formas, conforme acórdãos dos Tribunais Superiores.

A Reclamação 4.374/PE, de abril de 2013 o Min. Gilmar Mendes apreciou e entendeu que a Lei de Organização da Assistência Social (LOAS), no art. 203, V, da Constituição da República, estabeleceu critérios na concessão do benefício aos 

Neste sentido, fica comprovado que os critérios objetivados aos ditames da Lei $n^{\circ} 8.742 / 93$, são insuficientes para se atestar que o idoso ou o deficiente não possuem meios de se manterem ou de serem mantidos pela própria família.

Dessa forma, tratando-se do beneficio ao idoso, os princípios da igualdade e da dignidade humana, condizem conforme acórdão em sede de decisão jurisprudencial.

\begin{abstract}
AC 2004.38.03.007556-7/MG; APELAÇÃO CIVEL
Relator: DESEMBARGADORA FEDERAL NEUZA MARIA ALVES DA SILVA SEGUNDA TURMA - Publicação: 24/11/2008 e-DJF1 p.116

Ementa: PREVIDENCIÁRIO. CONCESSÃO DE BENEFÍCIO. AMPARO ASSISTENCIAL AO IDOSO. LEI 8.742/93 (LOAS). ART. 34, PARÁGRAFO ÚNICO, DA LEI 10.741/2003 (ESTATUTO DO IDOSO). RENDA PER CAPITA FAMILIAR. CONCESSÃO DO BENEFÍCIO A PARTIR DA CITAÇÃO. CORREÇÃO MONETÁRIA. JUROS DE MORA. SALÁRIO-MÍNIMO VIGENTE EM CADA COMPETÊNCIA. CUSTAS E HONORÁRIOS ADVOCATÍCIOS.

$[\ldots]$

3. Comprovados os requisitos - idade mínima e requisito econômico - tem direito a autora à concessão do benefício desde a data da citação, tendo em vista a ausência de requerimento administrativo. Apelação provida. (Grifo nosso)
\end{abstract}

Em outro sentido, importante a interpretação acerca da invalidez, em sede de análise e provimento deferido por Tribunal Regional Federal, "ipsis litteris":

\begin{abstract}
PREVIDENCIÁRIO. BENEFÍCIO ASSISTENCIAL. ADULTO, MAIOR, INVÁLIDO. INCAPACIDADE PARA O TRABALHO DEVIDAMENTE DEMONSTRADA PELA PROVA MATERIAL. VULNERABILIDADE SOCIOECONÔMICA DO GRUPO FAMILIAR. ESTUDO SOCIAL. TEMA DA COMPOSIÇÃO DO CÁLCULO DA RENDA FAMILIAR PER CAPITA, QUANTO AO LIMITE OBJETIVO POSTO PELA LOAS (LEI ORGÂNICA DA ASSISTÊNCIA SOCIAL). [...] 3. O requisito econômico para a concessão do benefício consistente na exigência de que a renda familiar per capita seja inferior a $1 / 4$ do salário mínimo (art. 20, caput e §3어 da Lei $n=8.742 / 1993)$, deve ser entendido como um limite objetivo, sendo que a avaliação da miserabilidade do grupo familiar, na hipótese de superação daquele limite, seja procedida não de modo abstrato, mas considerando as peculiaridades do caso concreto. Afinal, despesas decorrentes dos necessários cuidados com a parte autora, em razão de sua deficiência, incapacidade ou avançada idade, importam em gastos - notadamente com medicamentos, alimentação, taxas, impostos, moradia, tratamento médico, entre outros -, que são, nesse sentido, relevantes para a avaliação da real situação econômica do grupo familiar. (TRF4, AC 2008.70.99.002936-1, Quinta Turma, Relatora Maria Isabel Pezzi Klein, D.E. 29/03/2010). (Grifo nosso)
\end{abstract}

A análise dos méritos, os relatores apreciaram os feitos considerando a constitucionalidade fática da miserabilidade atestada, ser patente de veracidade aos desprovidos de benefícios. Fatos estes que vigoram recursos, e que foram considerados 
em razão da LOAS uma interpretação legal de não presunção comprovada para as hipóteses do benefício assistencial, baseado na renda auferida de $1 / 4$ do salário mínimo para subsistência dos considerados deficientes na lei e idosos.

\section{CONCLUSÃO}

Apreciando os aspectos de caráter prático da reformulação da Lei de Benefício de Prestação Continuada - LOAS, exprime-se em dizer que possuí acentuados avanços com a Lei Orgânica estabilizando direitos sociais, entretanto, a doutrina e a jurisprudência avaliem a demanda de ações, a fim de evitar retrocessos na seara jurídica processual.

Na conjuntura, o fato é que o presente estudo aportou à questão do benefício previdenciário perante a questão da miserabilidade, buscando identificar a possibilidade de ingresso aos mais excluídos de sua própria sobrevivência, identificando possíveis pontos controversos dos poderes públicos e julgando direitos necessários dos cidadãos, consoante o estabelecido na Lei Orgânica da Assistência Social, Lei n. 8.742/93, para que sejam considerados hipossuficientes, mantendo a si próprio e a família.

Deste modo, a questão ainda é muito debatida e requer ser amplamente discutida, pelo fato de não alcançar em sua totalidade a realidade do direito pelos poderes públicos, observando as medidas judiciais reivindicadas para o acesso aos benefícios de assistência social, uma vez que, necessita de análises comprovadas atestando à questão da miserabilidade.

Os artigos 194 e 203 caput da Constituição Federal destaca a Seguridade Social, como um conjunto integrado de ações a assegurar direitos relativos à Saúde, à Previdência e à Assistência Social retratada à Seguridade, de acordo com o que exibe a Lei n. 8.742/93, instituindo direitos sociais e legais às pessoas.

Conclui-se, portanto que a comprovação de uma renda per capita inferior ou superior a $1 / 4$ do salário mínimo, não demonstra a realidade auferida, muito menos satisfaz as exigências constitucionais, denotando uma realidade cominada à miséria de indivíduos vivendo por conta própria e risco. São critérios que carecem de análises para serem deferidos pelas legislações vigentes e infraconstitucionais garantindo esses direitos, àqueles comprovadamente beneficiários por seu caráter necessário e social. $\mathrm{E}$ nesse diapasão, o Judiciário busca soluções através de ações necessárias e decisivas 
sobre os critérios estabelecidos, como medida de resguardo e de direitos aos mesmos sem que acometa ao erro grosseiro, devendo ser imparcial mais visando à miserabilidade dentro dos moldes do principio da Dignidade da Pessoa Humana.

\section{REFERÊNCIAS}

AgRg no REsp 529928/SP, Rel. Ministro ARNALDO ESTEVES LIMA, QUINTA TURMA, julgado em 06/12/2005, DJ 03/04/2006 p. 389. Disponível em: < http://www.direitonet.com.br/jurisprudencia/exibir/82360/STJ-AgRg-no-REsp529928-SP-agravo-regimental-no-recurso-especial-2003-0072902-0>. Acesso em: 21 jul. 2019.

. Decreto no 6.214 de 26 de setembro de 2007. Regulamenta o benefício de prestação continuada da assistência social devido à pessoa com deficiência e ao idoso de que trata a Lei no 8742, de 7 de dezembro de 1993, e a Lei no 10741, de 1 ㅇ de outubro de 2003, acresce parágrafo ao art. 162 do Decreto no. 3048, de 6 de maio de 1999, e dá outras providências. Disponível em: < https://www.planalto.gov.br/ccivil_03/_Ato2007-

2010/2007/Decreto/D6214.htm>. Acesso em: 20 de julho de 2019.

Decreto no 7.617 de 17 de novembro de 2011. Altera o Regulamento do Benefício de Prestação Continuada, aprovado pelo Decreto no 6.214, de 26 de setembro de $2007 . \quad$ Disponível em: < htthttp://www.planalto.gov.br/ccivil_03/_ato20112014/2011/decreto/d7617.htm>. Acesso em: 20 de julho de 2019.

. Lei no 10.741, de 01 de outubro de 2003. Dispõe sobre o Estatuto do Idoso e dá outras providências. Disponível em: < http://www.planalto.gov.br/ccivil_03/leis/2003/L10.741.htm>. Acesso: 18 julho 2019.

. Lei no $\mathbf{1 2 . 4 3 5}$ de 06 de julho de 2011. Altera a Lei no $\underline{\mathbf{8 . 7 4 2}}$, de 7 de dezembro de 1993, que dispõe sobre a organização da Assistência Social. Disponível em: <http://www.planalto.gov.br/ccivil_03/Leis/L12435.htm>. Acesso em: 18 jul. 2019.

. Lei no 8.742, de 07 de dezembro de 1993. Dispõe sobre a Lei Orgânica da Assistência Social dá outras providências. Disponível em: <http://www.planalto.gov.br/ccivil_03/Leis/L8742.htm>. Acesso em: 21 jul. 2019.

STF. Rcl no 4374/PE, do Supremo Tribunal Federal, de abril 2013. Assunto: analise da constitucionalidade do § 3ㅇ do art. 20 da lei 8;742/93 (Lei Orgnânica da Assistência Social - LOAS). Disponível em: <http://www.stf.jus.br/arquivo/cms/noticianoticiastf/anexo/rcl4374.pdf>. Acesso em: 21 juL. 2019. 
.AC 2004.38.03.007556-7/MG; APELAÇÃO CIVEL Relator: DESEMBARGADORA FEDERAL NEUZA MARIA ALVES DA SILVA - SEGUNDA TURMA - Publicação: 24/11/2008 e-DJF1 p.116. Disponível em: < https://trf1.jusbrasil.com.br/jurisprudencia/18986290/apelacao-civel-ac-77180-mg20090199077180-7>. Acesso em: 21 jul. 2019.

AMADO, Frederico. Direito e Processo Previdenciário. Bahia: Juspodivm, 2015

KERTZMAN, Ivan. Novo regulamento da previdência social. São Paulo: Editora Jus Podivm, 2010.

NETO, Claudio Pereira de Souza; SARMENTO, Daniel. A previdência social como direito fundamental. Rio de Janeiro: Editora Lumen Juris, 2009.

NUNES, Luiz Antônio Rizzatto, O princípio constitucional da dignidade da pessoa humana: doutrina e jurisprudência. São Paulo: Saraiva, 2002.

SANTOS, Marisa Ferreira dos. Direito previdenciário esquematizado. São Paulo: Saraiva, 2011.

SARLET, Ingo Wolfgang. A eficácia dos direitos fundamentais. Porto Alegre: Livraria do Advogado, 2001. 


\title{
CAPITULO XI
}

\section{DIREITO DO TRABALHADOR RURAL - PRECEITOS CONSTITUCIONAIS E DIREITOS FUNDAMENTAIS}

\author{
DOI: 10.51859/AMPLLA.EDL1037-11
}

\author{
Débora Benicio Alves ${ }^{1}$ \\ Carlos Sampaio Peixoto Filho ${ }^{2}$
}

\begin{abstract}
${ }^{1}$ Especialista em Direito Previdenciário e Trabalho - URCA
${ }^{2}$ Mestre em Direito do Trabalho e Relações Internacionais do Trabalho, Professor da Faculdade de Ciências Humanas do Sertão Central.
\end{abstract}

\section{RESUMO}

O presente trabalho tem como objetivo analisar fontes de melhorias nas condições do trabalhador rural, na qual desempenha na agricultura uma das atividades essenciais para o desenvolvimento econômico e sustentável do país, no entanto, os trabalhadores que desempenham esta atividade não têm seus direitos trabalhistas e previdenciários devidamente resguardados e em sua grande maioria vivem e trabalham em condições precárias. Ressalta-se que no Brasil esse problema se arrasta há anos, desde a formação do país, pois o desenvolvimento da agricultura e do pastoreio não despertou o mesmo interesse ao legislador em relação à regulação do trabalhador urbano. Tal observação esta denominada na Consolidação das Leis do Trabalho (CLT), publicada em 1943, onde é nítida a preocupação quanto à regulação e proteção do trabalhador urbano. Ao passo que, o trabalhador rural encontra-se visivelmente excluído da esfera dessa proteção legal através da disposição do art. 7ำ, alínea " $b$ ", da CLT. Desta feita, nasce a necessidade de investigação e análise dos motivos que geram tal precariedade dos direitos desta importante categoria de trabalhadores.

Palavras - Chave: Trabalhador Rural, Direitos, Amparo Legal, Precariedade, Proteção. 


\section{INTRODUÇÃO}

A Consolidação das Leis do Trabalho (Decreto-lei no 5.452/43) eliminou os trabalhadores rurais de sua proteção, e menciona que apenas os trabalhadores urbanos eram regidos por seus dispositivos. Entretanto, visando gerar igualdade entre os dois setores, a Constituição Federal de 1988 ampliou aos rurais a aplicação da Consolidação das Leis do Trabalho, sem que houvesse, uma real análise das diferenças existentes entre ambos.

Desse modo, o que segue é uma apreciação acerca dos trabalhos instituídos no campo e o direito constitucional de igualdade substancial entre empregados urbanos e rurais, elencado no artigo 7ํㅡ, caput, da Constituição Federal.

O direito do trabalho rural atualmente é conduzido, pela Constituição Federal, pela Consolidação das Leis do Trabalho e pela Lei n. 5.889/73, dentre outras leis esparsas. A Constituição Federal de 1988 foi importante no progresso do direito do trabalho e nas relações entre empregados rurais e empregadores. Isso porque ela instituiu, no caput de artigo 7ํㅡ, que os trabalhadores urbanos e rurais são iguais perante a lei, sendo sujeitos dos mesmos direitos.

Contudo, a Lei n. 5.889/73 determina apenas a aplicação da CLT nos casos omissos. E no que diz respeito, à lei é completamente voltada para o setor urbano. Nessa circunstancia, a dificuldade se concretiza entre a igualdade do setor urbano e o rural em relação aos contratos individuais de trabalho rural, pois a legislação não acolhe às necessidades impostas pelas diversidades doempregado do campo e este se vê vinculado a um contrato que muitas vezes não reflete a realidade do trabalho exercido.

O documento constitucional contém importantes preceitos que comprovam a finalidade do constituinte em buscar igualdade substancial. Vale frisar que apesar da Constituição vedar a discriminação, esta não pode ser confundida com diferenciação, na qual, às vezes é necessária justamente para se aplicar a igualdade substancial.

Sendo assim, determinadas diferenciações podem parecer necessárias para que os trabalhadores rurais tenham todos os direitos constituídos pela Carta Magna assegurados em seus contratos de trabalho. 
Apesar de os trabalhadores rurais permanecerem sob o abrigo de lei especial 5.889/73, a basilar reguladora das relações de emprego no Brasil, a Consolidação das Leis do Trabalho, é inteiramente voltada para o setor urbano.

É evidente que uma lei criada com a finalidade de regular o trabalho urbano não será suficiente para preencher as lacunas de lei especial, criada para os trabalhadores rurais. O fato, é que as leis em vigor ignoram todas as características do processo produtivo existentes na atividade rural. É necessária uma ampla mudança na legislação trabalhista brasileira, voltada exclusivamente para a realidade.

\section{CONCEITO DE TRABALHO RURAL, TRABALHADOR RURAL E EMPREGADOR RURAL}

De acordo com a Convenção $\mathrm{n}^{\circ} 141$ da OIT, aprovada pelo Decreto Legislativo 5/93, o conceito de trabalhador rural abarca não só o empregado rural, como as pessoas que prestam serviços ou tenham ocupação similar ou conexa.

O trabalhador rural tem sua definição no art. 20 da lei 5.889/73 é toda pessoa física que, em propriedade rural ou prédio rústico, presta serviços de natureza não eventual a empregador rural, sob a dependência deste e mediante salário.

$\mathrm{O}$ art. 3으 da mesma lei considera empregador rural toda pessoa física ou jurídica, proprietária ou não, que explore atividade agro-econômica, em caráter permanente ou temporário, diretamente ou por meio de prepostos e com auxílios de empregados. Inclui-se também neste caso a exploração industrial em estabelecimento agrário.

RENAULT e HOTT (ZIBETTI, 2009, p. 118) dizem que trabalhador rural é toda pessoa física, empregado ou não, que presta serviços pessoalmente, mediante contraprestação, em propriedade rural ou em prédio rústico, assim como na agroindústria.

Nesse sentido, empregado rural não é só aquele que presta serviços em prédio rústico ou propriedade rural, pois o empregado rural pode trabalhar na cidade e ser considerado trabalhador rural desde que sua atividade vise fins lucrativos, ou seja, trabalhador rural é toda pessoa física que trabalha com atividades de natureza agrícola.

A Convenção n.o 141 da Organização Internacional do Trabalho - OIT, art. 2으, definiu que abrange todas as pessoas dedicadas, nas regiões rurais, a tarefas agrícolas 
ou artesanais ou a ocupações similares ou conexas, tanto se trata de assalariados como, ressalvadas as disposições do parágrafo 2 deste artigo, de pessoas que trabalhem por conta própria, como arrendatários, parceiros e pequenos proprietários.

Em resumo, trabalhador rural é pessoa física que lida com atividades agrícolas, retirando deste o seu sustento. Contudo, o que se distingue do empregado rural do urbano é o seu empregador e não o local em que trabalha ou a atividade que exerce.

Seguindo este entendimento, Délio Maranhão leciona:

Fica desfeita, assim, a dúvida que o art. $7^{\circ}$ " $b$ " da Consolidação suscitava: se a atividade do empregado, ou a do empregador, é que caracterizava o trabalho rural. Sempre defendemos a posição que a Lei $n^{\circ} 5.889 / 73$ veio consagrar: é a natureza da exploração econômica do empregador, em que o trabalho é utilizado como fator de produção, que servirá, para caracterizá-lo ou não, como rural. (MARANHÃO, 1979, p. 55)

Depois da Lei $n^{\circ} 5.889$, persiste ainda a discussão do conceito de empregado rural. A celeuma não gira em torno dos elementos comuns: habitualidade, pessoalidade, subordinação, onerosidade. Estes elementos são idênticos aos do empregado urbano (da CLT). Contudo, o art. $7^{\circ}$, b, da CLT distingue. Vejamos:

Art. $7^{\circ}$ Os preceitos constantes da presente Consolidação, salvo quando for em cada caso, expressamente determinado em contrário, não se aplicam: (...) b) aos trabalhadores rurais, assim considerados aqueles que, exercendo funções diretamente ligadas à agricultura e à pecuária, não sejam empregados em atividades que, pelos métodos de execução dos respectivos trabalhos ou pela finalidade de suas operações, se classifiquem como industriais ou comerciais.

Conforme descrito acima, reforça o entendimento de que o um trabalhador rural ou urbano era conceituado segundo as atividades exercidas pelo trabalhador.

\subsection{DIREITOS INDIVIDUAIS DO TRABALHADOR RURAL}

Ao trabalhador rural aplicam-se as mesmas normas previstas na CLT (Lei no 5.452/43), com algumas diferenças, diante do art. 7ำ da CF/88 "São direitos dos trabalhadores urbanos e rurais, além de outros que visem à melhoria de sua condição social", aproximando com as demais classes de trabalhadores, com direitos na Constituição. Tais direitos específicos do trabalhador rural na Lei n. 5.889/73:

\footnotetext{
a. a intervenção segundo os usos da região, em qualquer trabalho contínuo de duração superior a seis horas, não computados na jornada de trabalho;

b. entre uma e outra parte da execução da tarefa diária, nos serviços caracteristicamente intermitentes, intervalo não computado como de serviço efetivo;
} 


\begin{abstract}
c. trabalho noturno entre 21 horas de um dia e 5 horas do dia seguinte na lavoura e entre 20 horas de um dia e 4 horas do dia seguinte na pecuária;

d. desconte de até $20 \%$ pela ocupação da moradia e de $25 \%$ pelo fornecimento de alimentação;

e. divisão proporcional do desconto de moradia sempre que mais de um empregado residir na mesma moradia;

f. não integração no salário da moradia e sua estruturas cedidas pelo empregador, assim como dos bens destinados à produção para subsistência do empregado e sua família;

g. contrato, nas regiões onde adota a plantação intercalar ou subsidiária (cultura secundária) a cargo do trabalhador rural, como um contrato com objeto próprio não identificável com o de trabalho.
\end{abstract}

Na seara ainda existe alguns princípios que regem estes mesmos trabalhadores, que se dividem em: Principio da proteção, Principio da irrenunciabilidade do direito, Princípio da continuidade da relação de emprego e Principio da primazia da realidade.

\title{
3. TRABALHADOR RURAL PERANTE A CONSTITUIÇÃO FEDERAL
}

As constituições Federais brasileiras inicialmente tratavam apenas sobre a forma de Estado e sobre o sistema de governo. Mas logo buscou tratar o direito de várias formas e de forma especial o direito do trabalho.

Muitos foram os fatores que contribuíram para a concepção do direito do trabalho no Brasil tanto no âmbito interno como externo, trazendo como grande impulso as greves da evolução industrial da Primeira Guerra Mundial e também a política trabalhista adotada pelo presidente Getúlio Vargas em 1930.

É de fundamental razão, ressaltar que a Constituição Brasileira de 1824 eliminou as corporações de ofício, e que em 1871 surgiu a Lei do Ventre Livre que dispunha que todos os filhos de escravos nasceriam livres a partir daquele momento. Posteriormente em 1885 surgiu a Lei do Sexagenário que libertava os escravos com mais de 60 (sessenta) anos de idade. E apenas em 13 de maio de 1888, foi assinada a Lei Áurea que aboliu a escravatura.

Porém só em 1934 as cartas Magnas brasileiras passaram a abordar o Direito do Trabalho, aprovada na Constituição de 1937, de 1946, de 1967 e por fim na Constituição atual de 1988.

Logo, surgiu em 1943 a CLT (Consolidação das Leis Trabalhistas) que juntou as várias leis esparsas existentes acrescidas de novos ordenamentos jurídicos. 
A Constituição Federal Brasileira garante os diretos dos trabalhadores rurais e urbanos em seu artigo 70 e assemelha o trabalhador rural ao urbano.

A doutrina de HOMMA (ZIBETTI 2009, p 73) transcreve a visão da Constituição Federal em relação aos trabalhadores:

A constituição Federal Brasileira de 1988 assegura no artigo 1 ํ que os valores
sociais do trabalho é um dos fundamentos do Estado Democrático de Direito.
Enquanto que no artigo 170 a Ordem Econômica é fundada na valorização do
trabalho humano, objetivando, assim assegurar a todos uma existência digna,
em conformidade com os direcionamentos da justiça social.

Embora existam algumas conquistas expostas na Constituição Federal de 1988 ainda existem dificuldades que os trabalhadores enfrentam para usufruírem dos seus direitos e garantias, como a informalidade do trabalho no campo, e algumas medidas encontradas pelo Estado para melhorias na classe para assim alcançarem seus direitos.

\title{
4. CONTRATOS DE TRABALHO
}

O trabalhador rural tem seus direitos dispostos na Lei 5.889/73 assegurados pela

Constituição Federal bem como pela CLT.

MARTINS afirma que:

\begin{abstract}
Os contratos rurais típicos, como o de parceria, meação, são regidos pelo Direito Civil. De acordo com artigo 17 da Lei no 5889/1973, a citada norma se aplica a qualquer trabalhador, mesmo que não seja empregado rural. As parcerias e meações fraudulentas que configurarem vínculo de emprego darão todos os direitos trabalhistas aos trabalhadores, que serão considerados empregados rurais. (MARTINS, 2010, p. 150)
\end{abstract}

MARTINS (2010, p. 150) ainda diz que: Tem privilégio especial sobre o produto da colheita, para a qual houver concorrido com seu trabalho, e principalmente a quaisquer outros créditos, ainda que reais, o trabalhador.

A prestação de serviços no meio rural se da de várias formas ao qual pode se dar através do trabalho autônomo, cooperado, pelo contrato de parcerias pecuária e agrária, pela a empreitada, pelo trabalho eventual dentre outros.

\section{AGRICULTURA FAMILIAR}

O artigo 5o, inciso XXVI da Constituição Federal dita o conceito de pequena propriedade. 
A pequena propriedade rural, assim definida em lei, desde que trabalhada pela família, não será objeto de penhora para pagamento de débitos decorrentes de sua atividade produtiva, dispondo a lei sobre os meios de financiar o seu desenvolvimento.

Todavia a Lei 8.629/93 preceitua a pequena propriedade na letra "a" do inciso II do seu artigo 4 .

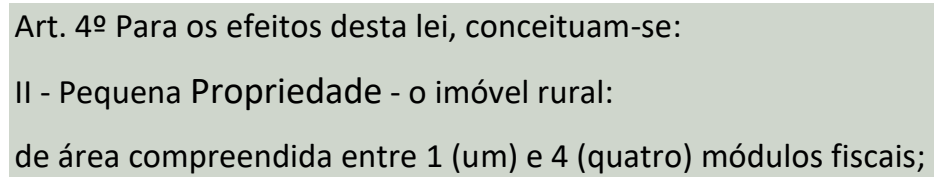

LISITA a caracterização da agricultura familiar:

\begin{abstract}
A caracterização da agricultura familiar utilizada pela FAO tem com pressuposto "(...) o trabalho e gestão intimamente relacionados; a direção do processo produtivo assegurado diretamente pelos proprietários; ênfase na diversificação; a ênfase na durabilidade dos recursos e na qualidade de vida; trabalho assalariado complementar; decisões imediatas adequadas ao alto grau de imprevisibilidade do processo produtivo". Na agricultura familiar, o produtor pode ter, eventualmente, empregados. Como não possui tecnologias que permitam a diminuição de riscos no processo produtivo, o ciclo agrobiológico fica sujeito a intempéries. (ZIBETTI, 2009, p. 88)
\end{abstract}

Já o inciso I do artigo 4 o do estatuto da Terra (Lei 4.504/64) preceitua propriedade familiar como:

O imóvel rural que, direta e pessoalmente explorado pelo agricultor e sua família, Ihes absorva toda força de trabalho, garantindo-lhes a subsistência e o progresso social e econômico, com área máxima fixada para cada região e tipo de exploração, e eventualmente trabalhado com ajuda de terceiros.

Logo ROZA exprime apoio ao pequeno agricultor.

Através de financiamentos bancários, com juros reduzidos, custeados pelo
governo federal, com fim de incrementar a agricultura familiar, o que
possibilita a este produtor a aquisição de maquinário mediante
financiamento a longo prazo, comprometendo parte da renda anual e incerta,
pois está sujeito aos intempéries, seu trabalho é um verdadeiro contrato de
risco, no entanto, a seca ou o excesso de chuva não o fazem parar de
trabalhar. (ROZA, BERWANGER, 2011, p. 38)

Com base nas discussões e entendimentos, pode-se concluir que a agricultura familiar, é quando a própria família é responsável pelo meio de produção, assim como assume o trabalho propriamente dito. 


\section{MEDIDAS TOMADA CONTRA A INFORMALIDADE}

A fiscalização do trabalho do âmbito rural e urbano tem por intuito a prevenção e a manutenção dos direitos trabalhistas essenciais à relação de trabalho, entretanto tal fato nem sempre acontece no meio rural.

LISITA ilustra a falta de fiscalização rural:

É certo, pois, que a fiscalização precária das relações trabalhistas, que
vigoram no campo, contribui em muito para manter a exploração do
empregado rural pelo seu empregador. Em geral, as fiscalizações ocorrem
após alguma denúncia. Por outro lado, enquanto alguns empregados não
fazem questão da carteira assinada porque não querem enfrentar o ônus da
contribuição previdenciária, desconhecendo até mesmo os benefícios desta,
outros, por sua vez, deixam de exigir do empregador rural seus direitos
trabalhistas, se acomodando por temer aborrecer este, correndo o risco de
perder o emprego. (LISITA, ZIBETTI, 2009, p. 96)

Em decorrência da informalidade ocasiona a ausência de garantias trabalhistas aos rurais, e a Constituição Federal de 1988 em seu Art. 70 igualou os direitos dos trabalhadores Rurais e Urbanos. Previamente a Carta de 1988 não era concedida por Lei direitos de modo mais igualitário, e o Brasil por ter extensão continental com lugares de difícil acesso nas zonas rurais, tornou-se difícil para a Justiça do Trabalho conseguir atender a demanda de trabalhadores que reivindicam seus direitos, além da fiscalização.

Nessa seara, ainda existem Leis que garante o direito do trabalhador, contudo há diferenças na concessão das garantias dos direitos e o trabalhador urbano por sua vez tem como requerer junto a Justiça do Trabalho seus direitos com maior facilidade assim que necessário, pois, há sempre um Órgão da justiça próximo e apto a atendê-lo.

Entretanto, com o trabalhador rural não acontece o mesmo, o acesso à Justiça do Trabalho se torna distante da realidade. Geralmente o trabalho rural fica longe da cidade, onde as estradas não são boas e não é fácil a locomoção, estes trabalhadores não têm como se deslocar até o órgão responsável para obtenção de direito.

O trabalhador rural é importante para economia de um país e o Brasil é grande produtor de alimentos tanto para consumo interno como para exportação sendo forte na agricultura e pecuária. Isso não seria possível sem a mão-de-obra do homem do campo. 


\section{PREVIDÊNCIA SOCIAL RURAL}

A previdência social é citada na obra de Oliveira como:

Uma organização criada pelo Estado, destinadas a prover as necessidades
vitais de todos que exercem atividade remunerada e de seus dependentes e,
em alguns casos, de toda a população, nos eventos previsíveis de suas vidas,
por meio de um sistema de seguro obrigatório, de cuja administração e
custeio participam, em maior ou menor escala, o próprio Estado, os
segurados e as empresas. (OLIVEIRA, MARTINEZ, 1998, p. 98).

Em 1960 o trabalhador rural foi incluído na previdência social por meio do Estatuto do Trabalhador Rural (Lei. 4.214/63) que regulamentou os sindicatos rurais e instituiu a obrigatoriedade do pagamento do salário mínimo dos trabalhadores rurais e criação do fundo de assistência. No entanto, a cobertura previdenciária aos trabalhadores rurais não se efetivou, pois não foram regulamentados em lei própria.

Em resumo, posteriormente cominada com as Leis no. 8.212 e №. 8.213 ambas de 1991, é que se passou a prever o acesso universal dos inválidos do setor rural à previdência social em regime especial. Hoje, a previdência social é parte da Seguridade Social e ocupa, desde a Carta de 1988, capítulos na Ordem Social: como um conjunto de ações, de responsabilidade dos poderes públicos, nas áreas de saúde, previdência e assistência social, regidas ao alcance de objetivos básicos de uma sociedade democrática: o bem-estar e a justiça social.

Por fim, apesar da conviç̧ão de que uma política pública, com a dimensão que tem a Previdência Social na área rural, não pode ser tratada sob a ótica meramente contábil que vincula receita e despesa relacionadas aos seus beneficiários diretos. Com isso os benefícios previdenciários rurais provocam uma revolução no campo brasileiro.

\subsection{ASPECTOS GERAIS DA APOSENTADORIA POR IDADE}

A Constituição Federal de 1988 trouxe uma conquista na concessão de direitos aos trabalhadores rurais, da forma concedida aos trabalhadores urbanos. Dentre eles, temos o direito à aposentadoria, previsto no art. 7ํ, XXIV, da Constituição Federal.

A aposentadoria concedida aos trabalhadores urbanos e rurais é sem dúvida o ponto da seguridade social. Quando se fala em previdência social, logo se pensa na velhice, ou seja, em como vai prover a sua subsistência quando não tiver condições de laborar, ou mesmo quando a capacidade laborativa for reduzida em razão do fator idade. 
Atualmente, temos a seguinte lição de Alencar (2009, p. 456): O risco idade avançada reporta-se a verdadeira política de emprego, mecanismo de recompensa aos mais experientes, e ainda aptos ao labor, pelas décadas de trabalho dedicadas à sociedade, a fim de permitir o ingresso dos mais jovens.

A aposentadoria consiste em benefício de prestação continuada, mensal e substitutivo do salário de contribuição, que cumpre carência e idade mínima.

Na alínea b, I, art. 18 da Lei no 8.213, de 1991 está o benefício de aposentadoria por idade, e tem como objetivo proteger a pessoa dos riscos sociais da idade avançada.

Atingindo o patamar de idade, o trabalhador não consegue mais garantir sua subsistência através de suas forças, já que sua capacidade laborativa é bastante reduzida, o que é normal, considerando uma vida inteira dedicada ao trabalho. Com isso, é necessário que o Estado garanta, através da aposentadoria por idade, que o trabalhador continue com suas necessidades sendo supridas até o final de sua vida.

A seguridade social qualifica o elemento idade para aposentadoria com dois critérios, o primeiro a adoção da aposentadoria por idade como contraprestação ou recompensa pelos anos de atividade produtiva. O segundo a aposentadoria por idade como benefício decorrente de incapacidade presumida em função da senilidade, critério adotado pelo Brasil (HORVATH JUNIOR, 2006).

Os art. 46 a 51 da Lei 8.213/91 trata da obtenção do benefício por idade, que deve ao segurado completar 65 anos de idade, se homem, e 60 anos, se mulher. Salvo os trabalhadores rurais que são reduzidos para 60 e 55 anos, respectivamente homens e mulheres. Essa redução justifica-se pela natureza do trabalho que é desenvolvido pelos trabalhadores rurais, que sofrem mais pela ação do tempo.

A idade não é o único requisito para que o segurado tenha direito ao benefício da aposentadoria por idade. A partir da Lei no 8.2113/91, além da idade, há ainda a carência de 180 (cento e oitenta) contribuições mensais a ser considerado.

\subsection{DOS DESTINATÁRIOS DA APOSENTADORIA POR IDADE RURAL}

A aposentadoria por idade pode ser concedida a trabalhadores urbanos e rurais. Contudo, estabelece Marisa Ferreira dos Santos (2015, p. 166) que: O empregado é aquele que presta serviço de natureza urbana ou rural à empresa, em caráter não 
eventual, sob sua subordinação e mediante remuneração, inclusive como diretor empregado.

Desse modo, existe diferença entre um trabalhador urbano e rural onde não é puro e simples o local onde o serviço é prestado, mas sim pela natureza da prestação.

Vale ressaltar também que o trabalhador rural é incluído na categoria dos segurados obrigatórios empregados. No entanto, nem sempre foi assim, pois antes da edição da Lei no 8.212/91, os trabalhadores rurais não eram segurados obrigatórios, o que os deixava em dificuldades na cobertura previdenciária (SANTOS 2015).

Os segurados especiais compõem, segundo a doutrina, a última categoria dos segurados obrigatórios enumerada pela lei de regência. Esses trabalhadores possuem peculiaridades que os diferenciam dos demais segurados da previdência social. (CASTRO; LAZZARI, 2014)

Os mesmos autores aduzem que a principal característica desta classe de segurados é que tais pessoas trabalham por conta própria e em regime de economia familiar, fazendo pequenas produções com as quais mantêm a sua subsistência. (CASTRO; LAZZARI, 2014)

Da análise dessa evolução legislativa, percebe-se que houve uma ampliação do conceito de segurado especial. Importante mencionar a advertência que Santos faz, aduzindo que o conceito de segurado especial é extremamente importante porque a lei pretende amparar aquele que faz da atividade laboral em pequenas propriedades 0 instrumento de seu sustento e de sua família (SANTOS, 2015, p. 179).

\subsection{DA APOSENTADORIA RURAL}

A redução da idade para a concessão de aposentadoria rural não viola nenhum princípio constitucional, pelo contrário, essa diferenciação de idades entre os trabalhadores urbanos e rurais é na [...] busca exatamente a igualdade. Se as idades fossem iguais, estaríamos diante de um à desigualdade (LADENTHIN, 2009, p. 68).

É sabido que o trabalhador rural exerce atividade extremamente penosa, desgastante, justificando a idade antecipada para o direito à aposentadoria previdenciária. Seria possível até considerar atividade especial, pois seu trabalho se expõe às condições variáveis do tempo e raios solares, sujeitando-o a sofrer doenças, o que pode ser considerado prejudicial à sua saúde e à sua integridade física. 
Nessa linhagem, trabalhadores urbanos e rurais não podem ser tratados como se fossem iguais, visto que estão submetidos a condições diametralmente opostas. Como se sabe, o trabalho exercido em ambiente rural é extremamente desgastante e causa mal à saúde do trabalhador, devido às condições expostas, como sol escaldante, manuseio de insumos tóxicos e inflamáveis, o que justifica um tratamento diferenciado.

Sobre isso, a doutrina trata a respeito do agravamento que o labor rural causa na saúde do indivíduo. Vejamos:

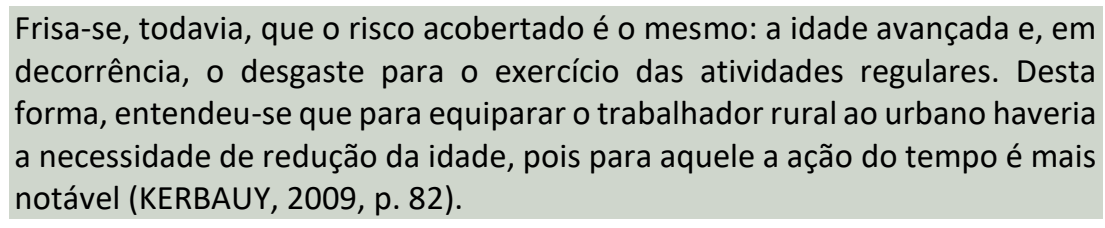

Dando sequência outro requisito exigido pela lei diz respeito à comprovação do efetivo exercício de atividade rural em relação aos meses imediatamente anteriores ao requerimento do benefício, mesmo que de forma descontínua, durante período igual ao da carência exigida para a concessão do benefício (IBRAHIM, 2012, p. 605).

A comprovação do labor é através da apresentação dos documentos previstos no art. 106 da Lei de Benefícios, com redação dada pela Lei no 11.718/08.

É importante ressaltar também que para obter o direito à aposentadoria por idade rural, o empregado rural não precisa comprovar a carência da tabela do art. 142, não sendo exigida a comprovação do vínculo, mas tão somente a prova da atividade rural. Isso porque a prova é feita a partir da comprovação do labor rural, não se exigindo, portanto uma formalização perante a previdência social.

Portanto, o trabalhador rural poderá requer aposentadoria por idade apenas pela comprovação do exercício da atividade durante quinze anos, contados a partir da data de vigência da lei (KERBAUY, 2009, p.87).

Completada a idade mínima para a aposentadoria por idade rural e comprovado o labor rural, o trabalhador fará jus à aposentadoria, nos termos prescritos pela lei.

\section{TRABALHADORES RURAIS EXCLUÍDOS DA LEI 5.889/73}

Na perspectiva do estudo, pode-se dizer que todos aqueles que trabalham no âmbito rural podem ser chamados de trabalhador rural. 
Aos trabalhadores rurais excluídos da lei 5.889/73 encontra-se: domésticos, parceiros, meeiros, arrendatários, empreiteiros, trabalhador em olaria, empregados de mineração, trabalhadores parentes dos pequenos proprietários rurais e industriais.

Contudo os empregados de escritório ou de lojas de empresas rurais, veterinários, agrônomos, médicos, tratoristas, motoristas, pedreiros, eletricistas, mecânicos, carpinteiros, enfim, trabalhadores rurais que não exerçam função de natureza rural, mais são considerados trabalhadores rurais.

\section{CONCLUSÃO}

O presente trabalho buscou demonstrar o trabalhador rural perante a legislação, a doutrina e a jurisprudência.

O interesse pelo tema abordado se deu por conta de um assunto de pouca discussão bem como nas academias de direito.

Existem muitos requisitos diferentes em relação às atividades dos trabalhadores rurais se comparados às atividades dos trabalhadores urbanos, e assim do mesmo jeito, muitos direitos salvaguardados, ou que deveriam ser, e estão relevados.

Nesse sentido aponta que em pleno século XXI apesar da abolição da escravatura pela lei áurea ainda de certa forma existe escravos, escravos da falta de informação, escravos do medo. Seres que desconhecem os seus direitos, pessoas sem registros na carteira que se quer pode se beneficiar dos direitos assegurados pela previdência social pelo desconhecimento e carência na educação, por baixa escolaridade, passa despercebido o direito, pois não acredita que os existe.

O contrato de trabalho do trabalhador rural, suas nuances e especificidades, apontam como se pode dar a prestação de serviços no meio rural, que no caso pode ser de várias formas: através do trabalho autônomo, cooperado, pelo contrato de parcerias pecuária e agrária, pela a empreitada, pelo trabalho eventual dentre outros.

Esse panorama permitiu conhecer o trabalho rural e ter uma noção bem ampla e completa de seus conceitos, dos direitos que estão vinculados, e os fenômenos jurídicos e sociais que aqueles que trabalham na terra precisam enfrentar, sempre em busca da sua subsistência através do trabalho.

O aplicador e detentor do direito precisa se voltar mais ao conhecimento da realidade jurídica e social do campo, com vistas a notificar eventuais desrespeitos não 
apenas a legislação infraconstitucional, assim como a normas imperativas advindas da própria Carta Magna de 1988 que apesar de expor alguns requisitos ainda deixa a desejar no sentido de assegurar e o direito do trabalhador rural dentro do próprio texto constitucional.

Somente um estudo criterioso, amplo permite conhecer essa realidade, que apesar de ter havido evolução histórica da luta pelos Direitos do Trabalhador Rural no Brasil ainda há que se falar, pois existem algumas peculiaridades a serem discutidas de forma clara em relação ao trabalho rural e urbano com detenção de direitos iguais, devendo prover meios de fiscalizar e sanar irregularidades com a categoria.

\section{REFERÊNCIAS}

. BRASIL. Constituição da Republica Federativa do Brasil de 1988. Disponível em: <http://www.planalto.gov.br/ccivil 03/constituicao/constituicao.htm> Acesso em 12 de janeiro de 2020.

CLT DINÂMICA. Consolidação das Leis do Trabalho. 1943. Disponível em: <http://www.trtsp.jus.br/clt-din.> Acesso em 06 de dez. 2019.

. Convenção no 141. Organização de Trabalhadores Rurais. De 24 de novembro de $1977 . \quad$ Disponível em: <https://www.ilo.org/brasilia/convencoes/WCMS_236114/lang--pt/index.htm> Acesso em 14 de dezembro de 2019.

. Lei no 4.504 de 30 de novembro de 1964. Dispõe sobre o Estatuto da Terra, e dá outras providências. Disponível em: <http://www.planalto.gov.br/ccivil_03/leis//4504.htm> Acesso em 13 de janeiro de 2020.

. Lei no 5.889 de 8 de junho de 1973 .Estatui normas reguladoras do trabalho rural. 1973. Disponível

em: <http://www.planalto.gov.br/ccivil 03/LEIS/L5889.htm.>Acesso em 06 de out. 2019.

. Lei no 8.212 de 24 de julho de 1991. Dispõe sobre a organização da Seguridade Social, institui Plano de Custeio, e dá outras providências. Disponível em: < http://www.planalto.gov.br/ccivil 03/leis//8212cons.htm> Acesso em 27 de dezembro de 2019.

. Lei no 8.213 de 24 de julho de 1991. Dispõe sobre os Planos de Benefícios da Previdência Social e dá outras providências. Disponível em: <http://www.planalto.gov.br/ccivil_03/leis//8213cons.htm> Acesso em 27 de janeiro de 2020. 
Lei $n$ o 8.629, de 25 de fevereiro de 1993. Dispõe sobre a regulamentação dos dispositivos constitucionais relativos à reforma agrária, previstos no Capítulo III, Título VII, da Constituição Federal. Disponível em: <http://www.planalto.gov.br/ccivil_03/leis//8629.htm> Acesso em 16 de fevereiro de 2019.

ALENCAR, Hermes Arrais. Benefícios previdenciários. São Paulo: Liv. Ed. Universitária de Direito, 2009.

BERWANGER, Jane Lucia Wilhelm. Previdência do trabalhador rural em debate. Curitiba: Juruá, 2011.

CASTRO, Carlos Alberto Pereira de; LAZZARI, João Batista. Manual de direito previdenciário. Rio de Janeiro: Forense, 2015.

HORVATH JUNIOR, Miguel. Direito Previdenciário. São Paulo: Editora Quartier Latin, 2008.

IBRAHIM, Fábio Zambite. Resumo de Direito Previdenciário - Niterói/RJ: Ímpetus, 2010.

KERBAUY, Luis. Previdência na área rural: benefício e custeio. São Paulo: Editora Ltr, 2009.

LADENTHIN, Adriane Bramante de Castro. Aposentadoria por Idade. Curitiba: Juruá Editora, 2009.

MARTINEZ, Wladimir Novaes. 0 trabalhador rural e a previdência social. São Paulo: LTr, 1985.

MARTINS, Sergio Pinto. Direito do Trabalho. São Paulo: Atlas, 2010.

NASCIMENTO Amauri Mascaro. Curso de direito do Trabalho. São Paulo: Ltr, 2000 apud OLIVEIRA, Elizabete. Dano Moral na relação do Trabalho. Itajaí-SC: monografia defendida na UNIVALI. 2008.

SANTOS, Marisa Ferreira dos. Direito Previdenciário esquematizado. São Paulo: Editora Saraiva, 2015.

ZIBETTI, Darcy Walmor. Trabalhador rural. Curitiba: Juruá, 2009. 


\title{
CAPITULO XII
}

\section{DIREITO TRIBUTÁRIO CONSTITUCIONAL: A (II)POSSIBILIDADE DO EXERCICIO DO PODER JUDICANTE AOS TRIBUNAIS ADMINISTRATIVOS FISCAIS}

DOI: 10.51859/AMPLLA.EDL1037-12

Pedro Rizzo Bazzoli ${ }^{1}$ Raphael Silva Rodrigues ${ }^{2}$

\begin{abstract}
${ }^{1}$ LLM em Direito Tributário pela PUC Minas. Especialista em Direito Tributário pelo IEC/ PUC Minas. Especialista em Direito de Empresa pelo IEC/PUC Minas. Especialista em Direito Público pelo IEC/PUC Minas. Bacharel em Direito pelo Centro Universitário Newton Paiva. Advogado.

${ }^{2}$ Doutorado em Direito pela UFMG e pela UAJFK, Mestre em Direito pela UFMG. Professor Universitário em diversos cursos de Graduação e Pós-Graduação Lato Sensu. Professor convidado do Curso de Doctorado em Ciencias Jurídicas y Sociales da UMSA, Buenos Aires, Argentina. Membro de diversos Conselhos Editoriais e Consultivos (livros e periódicos) e parecerista. Membro integrante de Bancas Examinadoras de Concursos Públicos. Autor e Coautor de livros, capítulos e artigos de revistas científicas. Advogado, consultor jurídico e parecerista.
\end{abstract}

\section{RESUMO}

O presente trabalho propõe a análise acerca da possibilidade do exercício do poder judicante dos Tribunais Administrativos Fiscais, sob a ótica da Constituição Federal de 1988.

Palavras-chave: Direito Tributário. Tribunais Administrativos Fiscais. Constituição Federal. 


\section{INTRODUÇ̃̃o}

De início, destaca-se que os Tribunais Administrativos Fiscais, em sentido geral, são órgãos inseridos na estrutura administrativa, com o desiderato de solucionar os conflitos não jurisdicionais, a que podemos denominar como conflitos equivalentes aos tutelados pelo Poder Judiciário.

Segundo Fredie Didier Jr. ${ }^{1}$, os Tribunais Administrativos "são chamados de equivalentes exatamente porque, não sendo jurisdição, funcionam como técnica de tutela dos direitos, resolvendo conflitos ou certificando situações jurídicas." (DIDIER JR., 2017).

Em verdade, os Tribunais Administrativos Fiscais são essenciais ao controle de atos da administração tributária, ou seja, inserindo-se no poder de autotutela ${ }^{2}$, sendo que as decisões adotadas no âmbito administrativo vinculam a Administração Pública Fazendária.

Por outro lado, aos contribuintes, é facultado recorrer ainda ao Judiciário para rever as decisões proferidas no âmbito dos processos administrativos fiscais.

Neste sentido, reforça-se que as decisões proferidas pelos Tribunais Administrativos, em tese, não fazem coisa julgada, exceto à decisão desfavorável à Administração ${ }^{3}$, sendo passíveis de controle pelo Judiciário, tendo em vista o princípio estampado em nossa carta magna, da inafastabilidade do Poder Judiciário. Vejamos:

\footnotetext{
${ }^{1}$ http://www.frediedidier.com.br/editorial/editorial-27/.

${ }^{2}$ Súmula 473 do STF

A administração pode anular seus próprios atos, quando eivados de vícios que os tornam ilegais, porque dêles não se originam direitos; ou revogá-los, por motivo de conveniência ou oportunidade, respeitados os direitos adquiridos, e ressalvada, em todos os casos, a apreciação judicial.

${ }^{3}$ Decreto n‥ 70.235 de 1972

Art. 45. No caso de decisão definitiva favorável ao sujeito passivo, cumpre à autoridade preparadora exonerá-lo, de ofício, dos gravames decorrentes do litígio.

Projeto de Lei da Câmara - no. 1.701 de 2007

Art. 1 o $\mathrm{O}$ art. 45 do Decreto $\mathrm{n}^{\circ}$ 70.235, de 6 de março de 1972, passa a vigorar acrescido do seguinte parágrafo único:

"Art. 45

Parágrafo único. Das decisões dos Conselhos de Contribuintes do Ministério da Fazenda, favoráveis ao contribuinte, de que não caiba recurso especial à Câmara Superior de Recursos Fiscais do Ministério da Fazenda, bem como das decisões favoráveis ao contribuinte dessa Câmara Superior, não cabe qualquer tipo de recurso, administrativo ou judicial, por parte da Fazenda Nacional. (https://www.camara.leg.br/proposicoesWeb/prop_mostrarintegra?codteor=488531\&filename=Tramit acao-PL+1701/2007).
} 


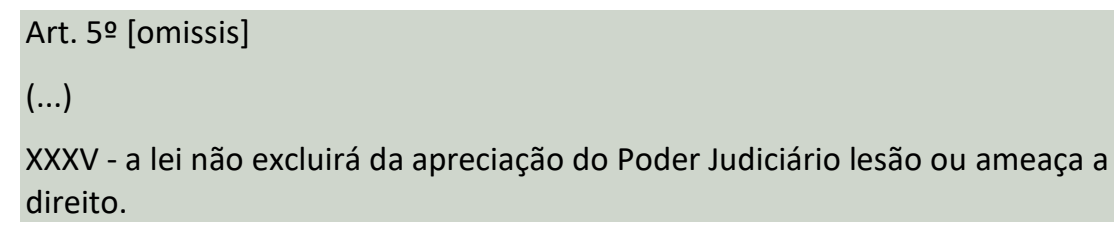

Ademais, o Supremo Tribunal Federal já evidenciou que aos contribuintes é facultado o exercício jurisdicional, tendo como consequência lógica, a renúncia da via administrativa:

\begin{abstract}
O direito constitucional de petição e o princípio da legalidade não implicam a necessidade de esgotamento da via administrativa para discussão judicial da validade de crédito inscrito em dívida ativa da Fazenda Pública. É constitucional o art. 38, parágrafo único, da Lei 6.830/1980 (Lei da Execução Fiscal - LEF), que dispõe que 'a propositura, pelo contribuinte, da ação prevista neste artigo (ações destinadas à discussão judicial da validade de crédito inscrito em dívida ativa) importa em renúncia ao poder de recorrer na esfera administrativa e desistência do recurso acaso interposto ${ }^{1}$.
\end{abstract}

Desta forma, não sendo necessário o esgotamento da via administrativa para acionar o Poder Judiciário e ante a concretização (ou não) da coisa julgada material, a tendência é desconsiderarmos os Tribunais Administrativos como verdadeiros Tribunais.

Feito este breve introito, abordaremos nesse artigo as funções dos Tribunais Administrativos para que possamos conclui, ao final, sobre a sua função judicante ou como uma instância revisora de atos administrativos, o que não desmerece a função, não olvidando-se da competência e da qualidade técnica destes órgãos administrativos fiscais.

\title{
2. DAS FUNÇÕES DOS TRIBUNAIS ADMINISTRATIVOS
}

A função administrativa ativa é aquela função em que não permite ao Estado qualquer inovação no ordenamento jurídico, sendo atividade típica desenvolvida pelo ente e por seus delegados, sob o regime de Direito Público.

Neste aspecto, o Estado está vinculado à aplicação concreta da Lei, atuando por razões de interesse ou utilidade pública, v.g., o lançamento tributário realizado pela Administração ou por seus agentes, quando edita unilateralmente um ato administrativo apto a produzir seus efeitos na esfera jurídica de terceiros ${ }^{2}$.

\footnotetext{
${ }^{1}$ RE 469.600 AgR, rel. min. Cármen Lúcia, j. 8-2-2011, 1ạ T, DJE de 3-3-2011.

2 BOTTALLO, Eduardo Domingos. Curso de Processo Administrativo Tributário. 2a. ed. São Paulo: Malheiros, 2009. p. 54.
} 
Nesse diapasão, podemos afirmar que estamos diante da função típica do Poder Executivo, no que tange à aplicação do princípio da legalidade, vinculando todos os atos da Administração à Lei, em sentido amplo.

Por outro lado, a função administrativa judicante é definida como função atípica da Administração, visando à solução dos litígios e a correta aplicação das leis tributárias pelas autoridades fiscais.

Nesta linha, diversamente do objetivo da função típica (ativa), que busca o interesse público consubstanciando nos atos administrativos para aplicação da legislação tributária, como a arrecadação, a função atípica (judicante), por sua vez, visa à "preservação da ordem jurídica globalmente considerada, ameaçada ou lesada por um ato da Administração Pública que seja contrário ao direito ${ }^{1 ”}$. (MALERBI, 2002, p.124).

Desta forma, entende-se que no exercício da administração judicante, a relevância passa a ser na proteção dos direitos subjetivos dos contribuintes que estão sujeitos às lesões que podem surgir em decorrência dos atos ou da atuação administrativa².

Em outras palavras, cumpre ao órgão julgador no âmbito administrativo apreciar a matéria apresentada pelo contribuinte quanto à aplicação correta da lei nas diversas situações em que lhe forem imputadas condutas sujeitas à responsabilização.

Neste sentido, a Administração Pública tem sua atuação limitada, por força de lei, de acordo com a disposição contida no artigo 142 do Código Tributário Nacional ${ }^{3}$, in verbis:

\begin{abstract}
Art. 142. Compete privativamente à autoridade administrativa constituir o crédito tributário pelo lançamento, assim entendido o procedimento administrativo tendente a verificar a ocorrência do fato gerador da obrigação correspondente, determinar a matéria tributável, calcular o montante do tributo devido, identificar o sujeito passivo e, sendo caso, propor a aplicação da penalidade cabível.

Parágrafo único. A atividade administrativa de lançamento é vinculada e obrigatória, sob pena de responsabilidade funcional.
\end{abstract}

Ademais, por expressa previsão legal e considerando a vinculação da atuação da Administração à norma, a priori, não se permite aos órgãos judicantes administrativos a

\footnotetext{
${ }^{1}$ MALERBI, Diva. Processo Administrativo Tributário. In: MARTINS, Ives Gandra da Silva (coord.). Processo Administrativo Tributário. 2ª ed. São Paulo: Revista dos Tribunais, 2002. p. 124.

2 BOTTALLO, op.cit. p. 54.

${ }^{3}$ Lei Federal no 5.172 de 25 de outubro de 1966.
} 
possibilidade de revisão, alteração ou cancelamento do procedimento em face de matéria constitucional, até então, não questionada em Juízo.

Sob esta ótica, já advertiu Hugo de Brito Machado Segundo:

É certo que os doutrinadores que defendem a possibilidade de a Administração declarar a inconstitucionalidade de uma lei têm o propósito de preservar a supremacia da Constituição, e dar máxima efetividade ao devido processo legal administrativo, à ampla defesa e ao contraditório.

Mas, não se pode negar, a tese pode ser empregada também para outras finalidades menos nobres, até porque, em última análise, admitir que a administração deixe de aplicar uma lei por considerá-la inconstitucional, independentemente de pronunciamento do Judiciário, implica atribuir ao Executivo a faculdade de julgar as leis às quais está submetido, atribuição que em muito se assemelha ao disposto nas Ordenações Filipinas, segundo as quais "nenhuma lei, pelo rei feita, o obriga, senão enquanto ele, fundado na razão e igualdade, quiser a ela submeter o seu poder real" (SEGUNDO. Livro 2, Título $35, \S 21)^{1}$

Resta demonstrado, portanto, que a função judicante atribuída aos Tribunais Administrativos, possui atipicidade, ressaltando que cabe a estes tribunais, em síntese, a revisão dos atos administrativos praticados, com vistas a manter intactos os princípios constitucionais e aqueles norteadores da Administração Pública.

\section{PODER JUDICIANTE: CONTROLE DE CONSTITUCIONALIDADE DAS LEIS}

Trata-se de matéria não pacificada na doutrina, observando-se que o tema é mesmo controverso entre juristas e aqueles que defendem a tese da possibilidade de negativa de aplicação de lei por inconstitucionalidade, incluídos assim na parte clássica doutrinária, anterior à Constituição Federal de 1988, podendo citar Miguel Reale, Themístocles Brandão Cavalcanti e Carlos Maximiliano.

Inclusive, Brandão Cavalcanti sustenta que o Poder Executivo apenas poderá negar aplicabilidade de lei quando $a$ "inconstitucionalidade esteja acima de qualquer dúvida razoável e havendo razões poderosas para a sua decretação ${ }^{2 \prime}$. (CAVALCANTI, 2012, P. 527).

\footnotetext{
${ }^{1}$ MACHADO SEGUNDO. Hugo de Brito. Impossibilidade de Declaração de Inconstitucionalidade de Lei pela Autoridade Administrativa de Julgamento. Revista Dialética de Direito Tributário, v.98. 2003.

${ }^{2}$ CAVALCANTI, Themístocles Brandão. Lei. Inconstitucionalidade manifesta recusa ao seu cumprimento pelo Executivo - legitimidade desse procedimento - veto já anteriormente manifestado. Doutrinas Essenciais de Direito Constitucional, vol. 5, p. 527, Mai/2011, DTR\2012\1137.
} 
Já Carlos Maximiliano (2015) assevera que $O$ "Executivo reprime os excessos do Congresso por meio do veto e do direito de não cumprir as leis manifestamente inconstitucionais $^{1 \prime \prime}$. (MAXIMILIANO, 2015, P. 252).

Lado outro, no que tange, especificamente, a matéria tributária, Valdir de Oliveira Rocha entende que a consulta fiscal realizada perante os órgãos da Administração Tributária possui o condão de submeter à análise deste ente, toda a legislação tributária, cabendo a apreciação quanto à constitucionalidade ou ilegalidade de ato normativo.

Ainda neste sentido, segundo lições de Oliveira Rocha (1996), incumbe ao órgão o atendimento das dúvidas suscitadas pelo contribuinte, cabendo o reconhecimento da matéria referente à inconstitucionalidade e ilegalidade normativa².

Por outro lado, a doutrina majoritária tem aplicado a tese quanto à impossibilidade de enfrentamento da matéria de inconstitucionalidade normativa, destacando-se o entendimento de Zeno Veloso que refuta qualquer negativa de aplicação de lei por inconstitucionalidade no âmbito da Administração Pública, se posicionando da seguinte forma:

Permitir que este poder, ex propria auctoritate, cancele a eficácia de norma
jurídica, porque reputa contrária à Constituição, é consagrar tese
perigosíssima, que pode pôr em risco a democracia, num País em
desenvolvimento, como o nosso, com tantas e tão graves limitações e
carências, com uma vocação histórica - e até o momento incontrolável - para
o autoritarismo, com um executivo verdadeiramente formidável e imperial,
significando o princípio da divisão de poderes quase uma letra morta no texto $_{\text {Magno }^{3} \text {. (VELOSO, 2000, p. 322-323). }}$

Corroborando com este entendimento, Hugo de Brito Machado Segundo ${ }^{4}$, sustenta que a permissão para que o Conselho de Contribuintes não aplique uma norma, tendo em vista considera-la inconstitucional, seria atribuir ao Poder Executivo a faculdade de julgar as leis às quais se encontra submetido, colocando em risco a eficácia do mandamento legal.

\footnotetext{
1 MAXIMILIANO, Carlos. Comentários à Constituição brasileira de 1891. Brasília: Senado Federal, Conselho Editorial, 2005. p.252.

${ }^{2}$ ROCHA, Valdir de Oliveira. A Consulta fiscal. São Paulo: Dialética, 1996, p. 37.

${ }^{3}$ VELOSO, Zeno. Controle jurisdicional de constitucionalidade. 2. ed. Belo Horizonte: Del Rey, 2000, p. 322- 323.

${ }^{4}$ MACHADO SEGUNDO, Hugo de Brito. Impossibilidade de declaração de inconstitucionalidade de lei pela autoridade administrativa de julgamento. Revista Dialética de Direito Tributário, v. 98, 2003, p. 98.
} 
E nesse cenário, alguns autores entendem que a matéria é de competência exclusiva do Poder Judiciário, não somente de lei, em sentido estrito, mas incluindo-se os decretos executivos, ainda que contrários a Lei Magna, devendo estes serem aplicados integralmente pelos Conselhos, enquanto não revogados pelo Supremo Tribunal Federal.

Neste sentido, Dejalma de Campos assevera que a "Justiça tributárioadministrativa assegura obrigatoriamente a aplicação de textos, ainda quando espúrios ${ }^{1 "}$. (CAMPOS, op. cit, p. 98).

Some-se ainda que existem entendimentos favoráveis ao controle de constitucionalidade pelo órgão Executivo, salientando que no exercício da competência do Conselho, uma vez suscitada matéria de inconstitucionalidade, pode-se conhecer e decidir acerca de tal alegação.

E assim, segundo entendimento de Gastão Luiz Lobo, citado na obra de Dejalma de Campos, a Segunda Instância Administrativa possui a função de analisar e exercer o controle de constitucionalidade e legalidade dos atos administrativos de natureza tributária e, constatada a afronta a dispositivos constitucionais ou legais, o Conselho de Contribuinte não só pode como deve anular este ato ao fundamento de inconstitucionalidade ou ilegalidade.

Ainda segundo Lobo, desta forma, não estaria o Conselho declarando a inconstitucionalidade da lei, mas exercendo o que o STF entende e já reconheceu à Administração Pública em geral, de anular ou revogar os próprios atos quando eivados de tais defeitos.

Este é o entendimento sumulado pelo Supremo Tribunal Federal, de acordo com o enunciado de no 473, em que a Administração Pública pode anular seus próprios atos, "quando eivado de vícios que os tornam ilegais, porque deles não se originam direitos; ou revogá-los, por motivo de conveniência ou oportunidade, respeitados os direitos adquiridos, e ressalvada, em todos os casos, a apreciação judicial" ${ }^{\prime \prime}$.

Neste diapasão, vislumbramos que a Suprema Corte baseou seu entendimento na aplicação do princípio da autotutela que, determina à Administração Pública a

\footnotetext{
${ }^{1}$ CAMPOS, op. cit. p. 98.

2 STF - Súmula no. 473 - Aprovação em Sessão Plenária de 03/12/1969 - Publicação no DJ de 10/12/1969, p.5929.
} 
verificação do ato que ofenda a Constituição Federal ou até mesmo a legislação infraconstitucional, se abstendo de convalida-lo, posto que viciado.

E mais, a remessa da matéria à apreciação do Judiciário no desiderato de invalidá-lo, pode ocasionar prejuízos aos administrados, aos cofres públicos e até mesmo ferir o princípio da celeridade.

Desta forma, considerando o princípio supracitado e o entendimento sumulado pelo STF, a Administração deve invalidar os atos administrativos revestidos de inconstitucionalidade.

E pelos ensinamentos de Roque Antônio Carrazza (1991), pode-se extrair a lição de que "o administrador público e o juiz - por não serem senhores, mas servidores da lei - estão intensamente subordinados à Constituição, inclusive a seus magnos princípios. É a ela, antes da própria lei, que devem mirar, enquanto desempenham suas relevantes funções ${ }^{1 "}$. (CARAZZA, 1991, p.150).

Noutro giro, no que concerne ao princípio da separação dos poderes, que no entendimento de alguns juristas, seria matéria reservada exclusivamente ao Poder Judiciário a função de análise da constitucionalidade das normas, salientamos que esta função não possui o "monopólio" deste Poder, mas a incumbência do controle final e derradeiro da constitucionalidade das normas.

Assim, em análise do próprio texto constitucional, não se verifica nenhum óbice ao Poder Executivo, no exercício de suas atribuições administrativas e no caso concreto, negar a aplicação de lei tida por inconstitucional, direcionando para o adequado desempenho de suas funções.

Juarez Freitas, por exemplo, nos ensina que a aplicação do princípio da legalidade é de suma importância, haja vista que traz a noção de guarda da constitucionalidade pela Administração Pública, ex vi do artigo 23, inciso I da Constituição Federal de 1988, que remete ao controle de conformidade de seus atos não apenas com as Leis, mas considerando todas as regras e princípios constitucionais ${ }^{2}$.

\footnotetext{
${ }^{1}$ CARRAZZA, Roque Antonio. Curso de Direito Constitucional Tributário. 3. ed. São Paulo: RT, 1991, p. 150.

2 FREITAS, Juarez. A guarda da constituição pela própria administração pública. Revista de Direito do Estado, Ano 4, n.o 15, p. 131-149, jul/set 2009. Rio de Janeiro: RENOVAR, 2009, p. 148.
} 
Por sua vez, Gilmar Ferreira Mendes ${ }^{1}$ entende que, após a Constituição Federal de 1988, vislumbra-se a possibilidade de deflagração do controle judicial pelo Chefe do Executivo, posicionando acerca da ampliação dos agentes legitimados processualmente para acionar o controle concentrado e abstrato de constitucionalidade perante o STF, o que respalda o entendimento de que cabe ao Judiciário a apreciação da matéria.

Em outro ponto de vista, agora pela estrita legalidade, o Conselho de Contribuintes, como de regra, não poderia julgar a inconstitucionalidade da lei.

Todavia, este acentuado entendimento positivista nos moldes e na concepção do Direito Tributário Moderno, clamam para que os Conselhos apliquem as normas e os atos que estão em consonância com a Constituição, valendo-se do parâmetro da segurança jurídica e da justiça fiscal.

Neste sentido, aponta-se a tendência da Administração Tributária para exercer o controle da juridicidade, tanto da constitucionalidade, como da legalidade das normas tributárias, pautando-se pela jurisprudência dos Tribunais Superiores.

Ademais, um exemplo deste controle exercido pela Administração está consubstanciado na orientação da Administração Pública Federal, realizada pela Procuradoria-Geral da Fazenda Nacional (PGFN) de não se aplicar ato normativo reconhecidamente ilegal ou inconstitucional pela jurisprudência pacífica e majoritária, conforme contido na Lei no 10.522 de 2002.

No caso em específico, os Procuradores da Fazenda Nacional estão autorizados ${ }^{2}$ a não contestar ou recorrer ${ }^{3}$ em processos que tratem de matérias que, em virtude de jurisprudência pacífica do Supremo Tribunal Federal, ou do Superior Tribunal de Justiça, sejam objeto de ato declaratório do Procurador-Geral da Fazenda Nacional, aprovado pelo Ministro de Estado da Fazenda ${ }^{4}$.

A doutrina que defende a possibilidade dos órgãos de julgamento administrativo conhecer da matéria de inconstitucionalidade de leis e atos normativos se arrima no dispositivo constitucional do artigo 5으, inciso LV, que trata das garantias da ampla defesa

\footnotetext{
${ }^{1}$ MENDES, Gilmar. O Poder Executivo e o Poder Legislativo no Controle de Constitucionalidade. Revista Tributária e de Finanças Públicas, vol. 20, p. 11, Jul/1997, Doutrinas Essenciais de Direito Constitucional, vol. 5, p. 205, Jul/1997, DTR\1997\319.

2 https://www.gov.br/pgfn/pt-br/assuntos/legislacao-e-normas/documentos-portaria-502/lista-dedispensa-de-contestar-e-recorrer-art-2o-v-vii-e-a7a7-3o-a-8o-da-portaria-pgfn-no-502-2016

${ }^{3}$ Portaria no 502, de 12 de maio de 2016.

${ }^{4}$ Parecer PGFN/CRJ/№ 492/2010, p. 7.
} 
e do contraditório, aplicáveis aos processos administrativos, vislumbrando a criação de uma jurisdição administrativa ${ }^{1}$.

Neste sentido, a autoridade julgadora, seja no âmbito judicial ou administrativo, não pode se eximir de "apreciar todas as questões levantadas pelos litigantes, inclusive e principalmente as de natureza constitucional. Se não o fizer, estará violando direito individual dos interessados 2 ".

Todavia, apesar das orientações doutrinárias com respaldo no texto constitucional a favor da apreciação e o julgamento da matéria relativa à constitucionalidade das normas, inclusive aplicando as regras e princípios que regulam o processo administrativo-tributário, alguns Estados editaram normas que vedam, expressamente, o pronunciamento sobre a matéria constitucional, exemplificando, através da Lei do Estado de Minas Gerais³

Outro exemplo de legislação estadual, porém, neste caso, aplicando o controle de constitucionalidade, é a do Estado do Amazonas ${ }^{4}$ que prevê, in verbis:

\begin{abstract}
Art. 252. A decisão de primeira instância resolverá as questões suscitadas no processo e concluirá para a procedência ou improcedência, total ou parcial, do lançamento do crédito tributário ou do pedido do contribuinte, definindo, desde logo, num e noutro caso, os seus efeitos e determinando a intimação das partes, a ser feita nos termos do artigo seguinte.

§ 10 A autoridade julgadora fará a apreciação de todas as questões suscitadas, à luz da Constituição, das leis, dos regulamentos e demais normas, segundo o grau hierárquico e formará o seu convencimento atendendo aos fatos e circunstâncias extraídas do processo, às alegações constantes dos Autos e à apreciação da prova. (Grifo nosso)
\end{abstract}

No âmbito federal, o Conselho Administrativo de Recursos Fiscais (CARF) editou súmula, após acórdãos paradigmas proferidos, no sentido de considerar que o aquele Conselho "não é competente para se pronunciar sobre a inconstitucionalidade de lei tributária ${ }^{\prime \prime}$.

\footnotetext{
${ }^{1}$ MARINS, James. Direito Processual Tributário Brasileiro (administrativo e judicial). 4. ed. São Paulo: Dialética, 2005. p. 355.

2 Acórdão 108-01.182, da 8ạ Câmara do Primeiro Conselho de Contribuintes da União, sessão de 14/06/1994.

${ }^{3}$ Lei estadual n. 6.763, de 26 de dezembro de 1975, art. 182, I.

4 Lei Complementar 19, de 29 de dezembro de 1997 (https://sapl.al.am.leg.br/media/sapl/public/normajuridica/1997/810/810_texto_integral.pdf).

5 Súmula CARF no 2 (http://idg.carf.fazenda.gov.br/jurisprudencia/sumulas-carf/quadro-geral-desumulas-1).
} 
E nessa toada, em julgamentos ${ }^{1}$ no CARF, tem sido reiterada de forma concisa a impossibilidade de se pronunciar sobre matéria de inconstitucionalidade ${ }^{2}$ :

(...). MATÉRIAS DE CUNHO CONSTITUCIONAL. NÃO CONHECIMENTO. Nos termos do enunciado da Súmula CARF no 2, o Tribunal Administrativo Tributário Federal de 2a Instância não é competente para se pronunciar sobre a inconstitucionalidade de lei tributária. Recurso que não se conhece. (...).

No âmbito estadual, o Tribunal de Impostos e Taxas da Fazenda do Estado de São Paulo sinalizava, há muito, a possibilidade de enfrentamento da matéria: "O Egrégio Tribunal de Impostos e Taxas por qualquer de suas Câmaras é competente para deixar de aplicar lei inconstitucional ou decreto ilegal em casos concretos ${ }^{3} . "$

Já no âmbito municipal, em Belo Horizonte, por exemplo, existe previsão expressa na norma que não se inclui na competência dos órgãos julgadores a declaração de inconstitucionalidade ou a negativa de aplicação da legislação municipal ${ }^{4}$.

Ainda neste sentido, o Conselho Administrativo de Recursos Tributários (CART), em seus julgados, refletem a disposição normativa, conforme acórdão abaixo colacionado:

[...] em sede do contencioso administrativo, de injustiça ou
inconstitucionalidade a fim de tornar inaplicável a Lei que determina a
imposição e fixa os respectivos percentuais, sobretudo por não se incluir na
competência do CART-BH a declaração de inconstitucionalidade e a negativa
de aplicação da legislação municipal (...)5.

Portanto, no âmbito administrativo-fiscal, não se olvidando dos argumentos favoráveis por parte da doutrina, os órgãos julgadores tendem a afastar de sua

${ }^{1}$ CARF. Proc. 10820.000940/2008-64. Relatora Ângela Sartori. №. Acórdão 3401-002.968. Sessão 19/03/2015.

${ }^{2}$ CARF. Proc. 10660.723497/2010-06. Relator Paulo Mateus Ciccone. Acordão no. 1402-005.248. Sessão de 09/12/2020.

${ }^{3}$ Tribunal de Impostos e Taxas do Estado de São Paulo. Proc. 2713/1995. Sessão de Câmaras Reunidas de 30/05/1995. Publicação no Diário Oficial do Estado em 25/07/1995.

${ }^{4}$ Decreto no. 14.456 de 16 de junho de 2011.

Art. 10 - Ao Conselho Administrativo de Recursos Tributários do Município - CART-BH, órgão integrante da estrutura da Secretaria Municipal Adjunta de Arrecadações da Secretaria Municipal de Finanças, compete decidir, em primeira e segunda instância administrativa, os contenciosos decorrentes de relação jurídica estabelecida entre o Município de Belo Horizonte e o sujeito passivo de obrigação tributária, concernentes aos créditos tributários, bem como aos atos administrativos referentes à matéria tributária, conforme dispuser este Regulamento.

$\S 1$ 10 - Ficam excluídos da competência do CART-BH o julgamento de impugnação de resposta exarada pelo órgão competente em face de consulta sobre a interpretação e aplicação da legislação tributária municipal, assim como a declaração de inconstitucionalidade e a negativa de aplicação da legislação municipal.

5 1a Câmara do Conselho de Recursos Tributários. Proc. 01-045.369/13-39. Relatora Luzia Jaqueline Domingos Costa. Acórdão 9.930/1 - Publicação 28/02/2015. 
apreciação as teses relativas à inconstitucionalidade ou ilegalidade de atos normativos, embasando nas próprias normas internas ou em seus regimentos, o que atrai assim, a inexistência (ou até omissão) do poder judicante aos tribunais administrativos fiscais.

\section{CONCLUSÃO}

A partir da análise e interpretação de todo o arcabouço doutrinário e normativo, verificamos que existe a possibilidade de apreciação pelos Tribunais Administrativos de matéria afeta à inconstitucionalidade de lei ou de ilegalidade de atos normativos, com respaldo em dispositivos constitucionais que, a priori, autorizam os órgãos administrativos julgadores, aplicando o princípio da segurança jurídica, da justiça fiscal e da autotutela, enfrentar as questões trazidas pelos contribuintes no que tange ao controle de constitucionalidade e legalidade de atos normativos tributários.

Neste sentido, diversamente do entendimento favorável da doutrina, os órgãos administrativos, com base em normativas no âmbito de sua territorialidade, afastam a apreciação da matéria, eximindo-se do enfrentamento e submetendo à competência exclusiva do Poder Judiciário. Ou seja, a Administração Tributária exerce seu papel de reprodutora das disposições legais, sustentando não ser competente para a análise das questões constitucionais postas em discussão.

Ademais, veda-se o pronunciamento pelo órgão administrativo pela inconstitucionalidade, considerando sua incompetência no julgamento destas questões, de acordo com entendimento majoritário dos Conselhos Administrativos Fiscais.

Todavia, o reconhecimento da Lei Maior como pilar para todo e qualquer ato normativo, implica no controle pela Administração dos seus atos jurídicos, em conformidade com o texto constitucional.

Mesmo diante da sólida fundamentação da doutrina, com respaldo na Constituição Federal de 1988, como exemplo, o Decreto no 70.235 de 1972 e o Regulamento do CARF, vedam aos membros das turmas de julgamento a negativa de aplicação da legislação sob o fundamento da inconstitucionalidade.

Contudo, determina que sejam respeitados os precedentes formados pelo plenário do STF em decisão definitiva, ainda que não se tenha proferido em controle concentrado de constitucionalidade, bem como os precedentes dos Tribunais 
Superiores, sob o rito de julgamento por recursos repetitivos ou pela reconhecida repercussão geral.

Desta forma, não se pode olvidar que a Constituição da República é a fonte normativa originária e principal, assim como seus princípios e regras jurídicas insculpidas em seus dispositivos, estando a Administração Pública obrigada a pautar sua atuação da forma como estabelece a Carta Maior, pois, admitir-se o contrário, configura flagrante retrocesso na garantia da defesa e dos direitos dos administrados, leiam-se, contribuintes.

Concluímos, portanto, que os Tribunais Administrativos atuam como instâncias acauteladoras dos atos administrativos, seja para mantê-los ou revisa-los, afastando, assim, o poder judicante próprio dos órgãos do Poder Judiciário, de modo que, organicamente, pertencem à estrutura administrativa (Poder Executivo) e não tribunais propriamente ditos (Poder Judiciário).

\section{REFERÊNCIAS}

BELO HORIZONTE (MG). Decreto Municipal no 14.456, de 16 de junho de 2011. Disponível em: < https://www.cmbh.mg.gov.br/atividade-legislativa/pesquisarlegislacao/decreto/14456/2011>. Acesso em: 11 de jun. 2021.

BOTTALLO, Eduardo Domingos. Curso de Processo Administrativo Tributário. 2a . ed. São Paulo: Malheiros, 2009.

BRASIL. Constituição da República Federativa do Brasil de 1988. Disponível em: < http://www.planalto.gov.br/ccivil_03/constituicao/constituicao.htm>. Acesso em: 11 de jun. 2021.

BRASIL. Decreto-Lei no 70.235, de 06 de março de 1972. Disponível em: <http://www.planalto.gov.br/ccivil_03/decreto/d70235cons.htm>. Acesso em: 11 de jun. 2021.

BRASIL. Lei no 5.172, de 25 de outubro de 1966. Disponível em: <http://www.planalto.gov.br/ccivil_03/leis//5172compilado.htm>. Acesso em: 11 de jun. 2021.

BRASIL. Lei no 9.784, de 29 de janeiro de 1999. Disponível em: <http://www.planalto.gov.br/ccivil_03/leis/l9784.htm>. Acesso em: 11 de jun. 2021.

BRASIL. Parecer PGFN/CRJ no 492, de 30 de março de 2011. Disponível em: $<$ https://www.gov.br/pgfn/pt-br/acesso-a-informacao/atos-da-pgfn- 
1/pareceres-da-pgfn-aprovados-pelo-ministro-da-

fazenda/2011/PARECER\%20CRJ\%20492-2011.pdf/view>. Acesso em: 11 de jun. 2021.

CAMPOS, Dejalma de. Direito Processual Tributário. 5ạ ed. São Paulo: Atlas, 1998

CARRAZZA, Roque Antonio. Curso de Direito Constitucional Tributário. 3a ed. São Paulo: Revista dos Tribunais, 1991.

CAVALCANTI, Themístocles Brandão. Lei. Inconstitucionalidade manifesta recusa ao seu cumprimento pelo Executivo - legitimidade dêsse procedimento - veto já anteriormente manifestado. Doutrinas Essenciais de Direito Constitucional, vol. 5, p. 527, Mai/2011, DTR\2012\1137.

ESTADO DO AMAZONAS. Lei Complementar 19, de 29 de dezembro de 1997. Disponível em:

<https://online.sefaz.am.gov.br/silt/Normas/Legisla\%C3\%A7\%C3\%A30\%20Esta dual/Lei\%20Complementar\%20Estadual/Ano\%201997/Arquivo/LCE\%20019\%20 97.htm>. Acesso em: 11 de jun. 2021.

FREITAS, Juarez. A guarda da constituição pela própria administração pública. Revista de Direito do Estado, ano 4, n. 15, p. 131-149, jul./set. 2009. Rio de Janeiro: RENOVAR, 2009.

MACHADO SEGUNDO, Hugo de Brito. Impossibilidade de declaração de inconstitucionalidade de lei pela autoridade administrativa de julgamento. Revista Dialética de Direito Tributário, v. 98, 2003, p. 98.

MACHADO, Hugo de Brito. Curso de Direito Tributário. 30a ed. São Paulo: Malheiros, 2009

MALERBI, Diva. Processo administrativo tributário. In: MARTINS, Ives Gandra da Silva (Coord.). Processo administrativo tributário. 2a ed. São Paulo: Revista dos Tribunais, 2002.

MARINS, James. Direito Processual Tributário Brasileiro (administrativo e judicial). 4aㅗ ed.

São Paulo: Dialética, 2005.

MAXIMILIANO, Carlos. Comentários à Constituição brasileira de 1891. Brasília: Senado Federal, Conselho Editorial, 2005. p.252.

MENDES, Gilmar. O Poder Executivo e o Poder Legislativo no Controle de Constitucionalidade. Revista Tributária e de Finanças Públicas, vol. 20, p. 11, Jul/1997, Doutrinas Essenciais de Direito Constitucional, vol. 5, p. 205, Jul/1997, DTR\1997\319. 
MINAS GERAIS. Lei Estadual no 6.763, de 26 de dezembro de 1975. Disponível em: https://www.almg.gov.br/consulte/legislacao/completa/completa-novamin.html?tipo=LEI\&num=6763\&ano=1975. Acesso em: 11 de jun. 2021.

ROCHA, Valdir de Oliveira. A Consulta fiscal. São Paulo: Dialética, 1996, p. 37.

VELOSO, Zeno. Controle jurisdicional de constitucionalidade. 2a ed. Belo Horizonte: Del Rey, 2000. 


\title{
CAPITULO XIII
}

\section{IIPPACTO DAS INSTITUIÇÕES DO DIREITO E DA ADMINISTRAÇÃO NO TRABALHO NO MUNDO PÓS-PANDEMIA}

\author{
DOI: 10.51859/AMPLLA.EDL1037-13
}

\author{
Rita de Cássia Marques Lima de Castro ${ }^{1}$ \\ Paulo Sergio de Castro ${ }^{2}$ \\ Gilvan Charles Cerqueira de Araújo ${ }^{3}$
}

\begin{abstract}
1 Pós-doutora - Faculdade de Economia, Administração, Ciências Contábeis e Atuárias - FEA-USP. Doutora em Ciências pela Universidade de São Paulo (Programa de Pós-graduação em Integração da América Latina). Professora na FEA-USP e no Programa de Pós-graduação em Integração da América Latina.

2 Pós-Graduando em Ciências pela Universidade de São Paulo (Programa de Pós-graduação em Integração da América Latina). Professor na Universidade de Mogi das Cruzes.

${ }^{3}$ Pós-graduando na Faculdade de Filosofia, Letras e Ciências Humanas da Universidade de São Paulo. Doutor em Geografia. Professor no Programa de Pós-graduação em Integração da América Latina.
\end{abstract}

\section{RESUMO}

Este trabalho realiza uma reflexão sobre o impacto das instituições do direito e da administração na construção do sentido do trabalho pós-pandemia. Como elemento presente na vida do ser humano desde os primórdios de sua atuação sobre a natureza, o trabalho reveste-se de centralidade que ultrapassa a mera satisfação de necessidades econômicas e alcança outras dimensões, como a social e a de saúde física e mental. Neste diapasão, a administração e o direito do trabalho, são elencados para estudo por serem as instituições sustentadoras das relações formais e informais no mundo do trabalho. No contexto de relações sociais trabalhistas na pós-pandemia, busca-se responder à questão de pesquisa: qual o impacto das instituições Administração e Direito do Trabalho, estruturadoras das relações sociais nas organizações, após a ruptura do modo tradicional de execução do trabalho com a pós-pandemia? Essa questão é respondida mediante pesquisa bibliográfica, em um estudo exploratório, de abordagem qualitativa e de natureza básica. Os resultados demonstram que o trabalho ainda se mantém como uma das principais categorias de construção do ser em sua integralidade, e que os principais desafios que se apresentam para a Administração e para o Direito do Trabalho estão em quebrar as amarras seculares que derivam de uma visão de colonialidade do poder para se transformarem em apoiadores do processo de edificação integral do ser humano, contribuindo para que ele tenha real possibilidade de ser e se desenvolver, de forma mais completa e digna, por meio de sua ação sobre o meio em que vive.

Palavras-chave: Direito do Trabalho. Administração. Instituições. Pós-pandemia. 


\section{INTRODUÇÃo}

O trabalho, categoria sempre presente na história da vida humana em sociedade, exerce uma centralidade na vida das pessoas. Suas distintas funções, como a social, a econômica e a do próprio valor intrínseco do trabalho em si, que traz autorrealização para o indivíduo, se imbricam para formar a pessoa humana de forma mais completa. A estrutura desta pesquisa deriva dessas diversas funções do trabalho e de sua associação com a Administração e o Direito, mais especificamente o Direito do Trabalho, ampliando os estudos já realizados, os quais demonstram que essas áreas de conhecimento têm reforçado somente o lado ter da relação trabalhista, não contribuindo para que o ser humano possa ser, no trabalho, ou seja, tenha o trabalho como um meio de formação integral e de construção e manutenção de sua dignidade.

Acrescenta-se a esses elementos de pesquisa a problemática causada por um novo contexto, advindo das relações sociais pós-pandemia e se constrói, portanto, a questão de pesquisa: se uma das principais funções do trabalho deriva das relações sociais que ocorrem na ação do ser humano sobre o meio em que vive, qual o impacto das instituições Administração e Direito do Trabalho, estruturadoras das relações sociais nas organizações, após a ruptura do modo tradicional de execução do trabalho com a pós-pandemia? Essa questão é respondida mediante pesquisa bibliográfica, em um estudo que, metodologicamente, se classifica como exploratório, de abordagem qualitativa e de natureza básica. O objetivo central pode ser assim expresso: Apresentar uma análise sobre o impacto das instituições Administração e Direito do Trabalho, estruturadoras das relações sociais nas organizações, após a ruptura do modo tradicional de execução do trabalho com a pós-pandemia.

A estrutura deste artigo traz, após esta introdução, a seção que apresenta um breve histórico sobre o papel do trabalho na vida do ser humano, intitulada O ser humano, o trabalho e a ciência da administração; em seguida, na seção 3, aborda-se o ser humano, o trabalho e o direito do trabalho; na seção 4, o que mudou com a pandemia, segue-se a conclusão e as referências. 


\section{O SER HUMANO, O TRABALHO E A CIÊNCIA DA ADMINISTRAÇÃO}

Trabalho. No decorrer dos séculos, passou por diversos momentos distintos em termos de conceito, e saiu de uma visão de algo penoso, torturante, para se revestir de uma interpretação mais positiva, tornando-se elemento útil na vida do ser humano, trazendo-lhe uma série de benefícios excedentes ao de uma troca de mão de obra por recompensa monetária. Destaca-se a ideia do valor social do trabalho contida em Marx (2013), Marx e Engels $(1965,1998)$ e Hegel $(1968,2005)$ e as discussões sobre a relação entre o ser humano e a natureza, com o foco nessa ação de caráter produtivo e modificador do meio que é resumido no termo 'trabalho'.

A Administração, enquanto ciência, toma importância nessa relação do ser humano com o trabalho a partir da primeira revolução industrial, ocorrida no século XVIII; do uso do carvão para a indústria, passando para o uso da eletricidade, de forma intensa, no século XIX, caracterizando a segunda revolução industrial. Nesses dois pontos históricos, há uma nova situação para o ser humano em sua relação com o trabalho: de dono e condutor do processo produtivo, o ser humano passa a ser um dos elementos desse processo produtivo (DATHEIN, 2003), perdendo seu papel protagonista e iniciador da cadeia produtiva para ser uma parte dela. Naquele momento, a administração inicia seu papel de analisar e controlar a produção e a condução das relações entre subordinados e gestores, visando ao alcance das metas organizacionais tomando por base os dois princípios que regem a administração: a eficiência (melhor utilização dos recursos) e a eficácia (o alcance dos objetivos).

A busca pela melhoria dos processos produtivos é marcante na evolução da Administração como na inserção de diretrizes produtivas a partir do mercado cambial, sistema financeiro internacional, a acumulação flexível; o uso da tecnologia, no século $\mathrm{XX}$, representa a terceira revolução industrial e o início do uso mais intenso de eletroeletrônica e de robôs como atuantes nas funções mais repetitivas do trabalho (HARVEY, 1996; FARAH JUNIOR, 2000). Chega-se, no século XXI, à quarta revolução industrial e à era da informação e internet, às máquinas que aprendem com elas mesmas e executam funções de pensar e tomar decisões (FLORIDI, 2014, TANASHIRO; GANAKA; CARDOSO, 2017). Essa quarta revolução industrial traz mudanças substanciais em termos de fusões de tecnologia e interação entre domínios físicos e biológicos 
(TEIXEIRA, 1998; SANSON, 2017) e o ser humano passa por mais um momento de reflexão sobre sua relação com o trabalho e de como esse trabalho pode, além de lhe trazer subsistência (o ter), Ihe permitir ser, o que significa formar-se enquanto ser humano por meio do trabalho, em tempos em que o consumo material e imaterial, efêmero ou de maior duração tornou-se um dos pilares do rearranjo do modo de produção capitalista contemporâneo, em sua versão financeiro-estético-informacional.

Atualizações produtivas, de circulação e consumo foram elevadas a patamares inéditos de implantação e desenvolvimento durante pandemia da COVID-19. Especificamente no que se refere a ações administrativas e dos direitos trabalhistas, foram necessárias diferentes, criativas e, em alguns casos, criticamente oportunas mudanças que foram estabelecidas como novo padrão do processo produtivo. Nesse ínterim pandêmico de transformações do modo de produção capitalista, já em curso, a inteligência artificial, por meio informatização socioprodutiva foi considerável em cenários de trabalho remoto, comunicação à distância, desenvolvimento de recursos interativos de trocas de informações e ativos financeiros e, até mesmo, de elaboração de formas diferenciadas do tão marcante consumo de entretenimento, uma das características fundamentais do capitalismo em sua versão contemporânea.

É oportuno lembrar que a ciência da Administração foi ampliando sua avaliação dessa complexa relação do ser humano com o trabalho; em suas descobertas, ficou patente o fato de que o trabalho é importante para o ser humano sentir-se completo, para obter autoestima e autorrealização (MAXIMIANO, 2015). Com as teorias que levaram a entender o ser humano como o homo complexus, a ciência da Administração foi abrindo caminho para uma interdisciplinaridade nos estudos sobre o ser humano e sua relação com o trabalho. Neste ponto, direciona-se o foco para a próxima seção: o Direito do Trabalho.

\section{O SER HUMANO, O TRABALHO E O DIREITO DO TRABALHO}

Nesse diapasão de relações complexas, o que se esperar do Direito do Trabalho? Que minimamente, esse ramo do direito seja um bastião da manutenção da dignidade humana, princípio que vale para todos os ramos do Direito, como destaca Miraglia (2010), lembrando ainda que o ser humano possui valor em si e não pode, em hipótese 
alguma, ser reduzido por força da convenção em um objeto ou coisa, como qualquer outro objeto ou coisa que, acrescentamos, faça parte do processo produtivo.

Pode-se argumentar que, historicamente, o Direito, em especial o do ramo do trabalho, reproduz, na América Latina, a visão de defesa do hipossuficiente (no caso, o trabalhador) mediante mecanismos de proteção social; no entanto, as mais recentes movimentações no mundo do trabalho trazem uma ruptura nessa linha protetiva, tornando as relações de trabalho ainda mais centradas na racionalidade instrumental que predomina a produção capitalista e na busca do ter em detrimento do ser. Ilustremos esse ponto com a reforma trabalhista de 2017: extinções de garantias que foram conquistadas ao longo de décadas como, por exemplo, as horas in intinere, foram excluídas com a reforma; a não obrigatoriedade da intervenção do sindicato em momentos de rompimento do vínculo trabalhista reduz a proteção ao empregado, elemento hipossuficiente nessa relação, a liquefação do capital atinge, desse modo, também a força de trabalho a partir dos argumentos as atualizações do sistema produtivo às exigências de suas próprias transformações na atualidade.

A demissão em massa, que passa a não ter a obrigatoriedade de autorização, a negociação de banco de horas de forma individual, são outros exemplos em que se reduz a força coletiva e se reforça uma relação direta entre empregador e empregado, o que impacta a segurança do trabalhador (BRASIL, 2017). Este mesmo percurso jurídicoadministrativo-comercial foi retomado, com força máxima, ao longo dos meses de impacto da pandemia, por meio da amplitude do alcance informacional das relações produtivas e de poder, agora mediados por recursos informacionais e de automação, muitas vezes, ainda encontrados em nichos produtivos e comerciais. Terminologias como biodigital ou pós-digital fortaleceram-se nos últimos meses, assim como novas configurações da sociedade da vigilância (ZUBOFF, 2019). A interface entre o humano e o robótico-informacional estreitou-se em níveis antes previstos para anos ou décadas à frente do que eram previstos.

Por outro lado, durante muito tempo a relação homem-trabalho ficou à mercê de mecanismos de controle em que o ser humano é simplesmente um mero objeto utilizado para produção, seja de produtos ou para prestação de serviços. Como apresentado na seção anterior, o ser humano, que antes era o ator principal de sua atividade produtiva, passa a fazer parte do meio dessa cadeia, não dependendo mais 
dele próprio, em termos de autonomia para a tomada de decisão, para dar início ao processo produtivo. O ser humano passa a ser uma máquina para trazer lucratividade para os senhores, e esses não tendem a levar em conta a condição individual desse ser humano, focando exclusivamente no processo produtivo.

O que foi bem apontado por Tartaret (2014, p. 133), no ponto de demonstrar o efeito do trabalho nas dimensões que excede a condição humana:

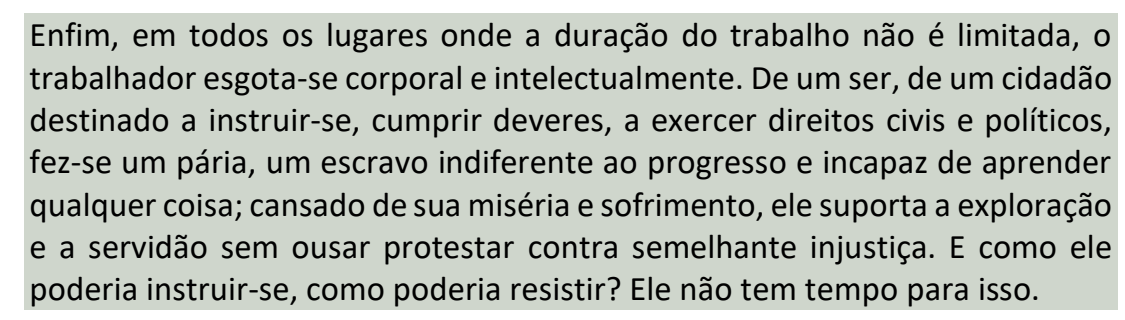

Para tanto, o próprio ser humano teria que ao longo do tempo perceber que as condições de trabalho deveriam ser avaliadas de forma crítica, sem que deixasse de lado a sua essência como pessoa, o que envolve a coletividade, a comunidade, a família, bem como a si próprio. Assim, não seria um conceito que mudaria seu entendimento no formato de trabalho, mas sim, um conceito que permitisse adaptar as relações homemtrabalho e condicioná-las a uma melhor condição tanto de trabalho e os seus interesses como pessoa que envolve outros atributos além do espaço de vida dedicado ao trabalho.

Aqui, cabe uma indagação: estaria a legislação do trabalho, na América Latina, contemplando essa visão mais holística do trabalho, em uma perspectiva, se não holística, ao menos que ultrapassasse os aspectos econômicos que norteiam as relações empregador-empregado? A resposta, ainda, mantém-se negativa. Os aspectos econômicos são a base estrutural das leis trabalhistas, o que pode ser evidenciado no período da pandemia, que levou à edição de medidas provisórias e legais que priorizavam aspectos voltados à produção.

Neste diapasão, há sempre uma incógnita na condição temporal nessa relação entre empregado-empresa nas resoluções de atribuições empregatícias a que as empresas submetem seus funcionários. No caso brasileiro, a um período regular de oito horas de trabalho, guardada suas exceções, cujo desenvolvimento de suas obrigações apresenta possibilidades de ser realizada em um prazo menor e com a mesma eficiência, como se pode constatar, por exemplo, quando as empresas estabelecem 'ritmos' de trabalho que são de entrega de tarefas, não de controle temporal. Quando esse modelo 
é adotado, os funcionários tendem a realizar as tarefas a eles designadas em tempos menores do que fariam se tivessem que cumprir uma jornada temporal.

A legislação comporta um limite de tempo para trabalho, mas não considera algumas questões que poderiam, na aplicação da lei, tornar o objetivo dessa lei mais efetivo. $O$ que se deve levar em conta para estabelecer um período de ' $x$ ' horas para permanência em um local de trabalho? Na prática, quais são as atividades que certo empregado realizou durante seu período em que esteve no trabalho? Essas atividades foram dimensionadas na condição de cumprimento de período de trabalho exigido pela lei? ou suas atividades foram dimensionadas para cumprimento para sua efetiva conclusão?

Partindo desta indagação, ao se observar os períodos que envolvem a permanência de um funcionário na empresa, pode-se encontrar alguns elementos que 'desviam' a função de trabalho quando considerado somente segundo um conceito de produtividade econômica. Tempo do café, redes sociais, paradas de relacionamento para assuntos que não se relacionam com a execução de suas atividades (...) pode-se observar que se subtrairmos tanto tempo de desvios de funcionalidade pela qual o empregado está cumprindo suas obrigações, ou melhor, se enxugássemos esse tempo e o empregado cumprisse suas atividades direcionadas e focadas para resoluções de suas atividades, poder-se-ia concluir que a execução e o término de suas obrigações diárias poderiam ocorrer em prazo menor.

Isso não somente deixaria o empregado focado em suas atividades e suas relações funcionais necessárias para a sua finalização. Pelo lado do empregado seria uma restrição que não é muito comum, já que está acostumado com essa folga nas relações de trabalho, independentemente, de ser uma exigência legal trabalhista, pois se tornou uma cultura ter esses espaços de 'não-trabalho' no momento 'temporal' de trabalho.

Pensar nos conceitos de jornada e horário de trabalho como Amaury Mascaro Nascimento (2006, p. 165) sintetiza nos leva a refletir quanto ao objetivo maior de se estabelecer um período 'legal' de permanência em um local de trabalho. 
destinados pelo trabalhador ao sistema produtivo, e horário de trabalho a pontuação do momento em que o trabalhador vai iniciar e terminar a sua atividade em cada dia, ou seja, a hora em que a atividade vai começar e a hora em que vai terminar.

A legislação latino-americana busca, com o estabelecimento de limites diários de trabalho, proteger o trabalhador de uma exploração de seu tempo. Como destaca Nava Gubert (2020, p. 51):

En materia de protección de los principales derechos laborales, nuestra
vigente constitución establece de forma taxativa en 8 horas diarias o 48 horas
semanales la jornada máxima ordinaria laboral, con lo que se consagra el
respeto ineludible a su reconocimiento como beneficio o conquista laboral
baluarte del derecho laboral. (...) En nuestro país, la lucha por que se
reconozca la jornada de las 8 horas de trabajo ha sido dura, llena de
obstáculos y tropiezos.

De igual modo, encontramos na obra organizada por Goldin (2009, p. 325), a estrutura legal de jornada laboral e descansos é considera "Pieza esencial de la prestación laboral" (...). Mais adiante, comenta: "el tempo de trabajo - la jornada de trabajo - es una dimensión esencial que define la más estricta materialidade de la prestación del trabajador" (GOLDIN, 2009, p. 325). Assim como na legislação apontada por Nascimento, a ideia de o trabalhador ficar disponível para a distribuição das tarefas é evidenciada nas demais legislações.

Embora a finalidade seja a proteção do trabalhador, o que se encontra, ainda, é que a limitação do tempo de trabalho não representa garantia de 'não exploração. Para a empresa, como pessoa jurídica que tem como finalidade o lucro, o controle do tempo de seus funcionários se apresentou, durante muito tempo, como uma estratégia eficiente de usar o espaço temporal de permanência dos funcionários no espaço laboral - afinal, o estar à disposição permite à empresa alocar mais atividades, reorganizar tarefas, redistribuir ações. Porém, veio a pandemia e a função controle, tão bem amparada pela lei, sofreu um abalo, pois o exercício da atividade laboral em sistema home office imposto pela necessidade de isolamento social gerou um desafio organizacional: o que fazer para controlar a atividade dos funcionários à distância?

Logo, o que parecia algo não tão positivo foi transformado, pelas empresas, em oportunidades de economia: os custos da permanência e a manutenção dos empregados no âmbito da empresa foram reduzidos substancialmente, e as empresas, no mundo todo, identificaram que a perda do controle do tempo 'diário' da atividade poderia ser compensado pela redução de custos com energia, limpeza para manutenção 
do espaço laboral, compra de móveis etc. Aliada à pandemia, reforçou-se a tecnologia como substituta da mão-de-obra humana - com menor possibilidade de 'problemas' de cunho legal, como processos e reclamações trabalhistas, e com resultados mais eficientes.

Isso pode ser observado plenamente em todos os ramos de atividades, como apontam Dupleix et al. (2014, p. 118):

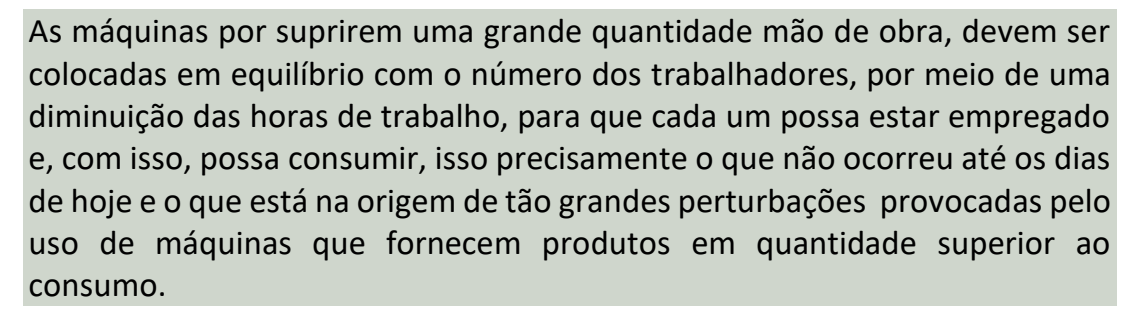

Esse problema do impacto da tecnologia versus empregado na empresa, tende a ser mais negativo para o empregado, como bem define Steens (2014, p. 125):

Essa simples declaração, clara, precisa e irrefutável, explica todas as queixas
dos trabalhadores contra máquinas. Ela demonstra com toda evidência que,
monopolizada nas mãos dos patrões, a máquina é o agente supremo da
prodigiosa e rápida elevação de sua fortuna e a causa da assustadora
diminuição dos salários.

Nota-se, então, que o ser humano (empregado) com essa diminuição de sua permanência no âmbito da empresa, poderia ter outras atividades (academia, passeios com a família, um melhor tempo com seus filhos para acompanhá-los na escola e seu crescimento etc.) bem como obter aprimoramento profissional, com cursos profissionalizantes e acadêmicos, aprendizado de uma língua estrangeira e outros, o que culminaria um aperfeiçoamento em sua área ou correlatas. Isso, evidentemente, se fosse levado em conta o fato de que o empregado precisa ter o tempo à sua disposição, a fim de ser o ser humano que possui uma qualidade de vida digna e que não o deixa ser transformado em uma máquina.

Observa-se, pelos exemplos dados, que o foco se restringe a questões de cunho econômico; outros aspectos igualmente importantes, voltados à manutenção da saúde física e mental do trabalhador, se já não eram observados antes da reforma trabalhista, tampouco o serão em um momento histórico em que se identifica uma precarização do trabalho, em ambiente de intensa competitividade e grande exigência pelo ter, em detrimento do ser. Ambiente este em que a palavra dignidade fica esmaecida e esquecida, quando deveria ser um imperativo no Direito do Trabalho. 
Deve-se sublinhar que a dignidade está associada à figura do trabalho digno, que permita ao ser humano garantir sua subsistência e permita a existência de uma vida digna. Possibilidades de ter liberdade para escolher o trabalho, de exercê-lo em ambiente de salubridade, de estar em um ambiente em que haja igualdade de oportunidades de ascensão e que haja tempo para descanso, bem como ter um trabalho que garante ou preserve a saúde do trabalhador em seus âmbitos físico e mental se esvaíram ou se reduziram muito com a pandemia, justamente o objeto de discussão da próxima seção.

\section{0 QUE MUDOU COM A PANDEMIA}

Antes de discutir o principal ponto de mudança no trabalho decorrente da pandemia, faz-se necessário destacar o controle no trabalho e do trabalho como um dos principais pilares da administração e que são muito observados em ações envolvendo contestações na justiça sobre as relações do trabalho e sendo um dos principais pontos que envolvem as relações de trabalho na pandemia e na pós-pandemia.

\subsection{O CONTROLE DO TRABALHO E A COLONIALIDADE DO PODER}

O controle no trabalho deriva, dentre outros fatores culturais e que reforçam a tecnicidade nas relações de trabalho como busca constante de eficiência e eficácia, de uma visão de colonialidade (LANDER, 2003; QUIJANO, 1988), isto é, de uma perspectiva em que o trabalho é visto como uma relação de senhorio, de senhor sobre um servo, o trabalhador. A colonialidade do poder refere-se à forma econômica e instrumental que se adota para apropriar-se da natureza, visando manter a estrutura de exploração que visa à acumulação de capital (ASSIS, 2014; HARVEY, 1996). Ela também demonstra como as relações sociais são estruturadas com base em uma lógica de desigualdade e de domínio - da metrópole sobre a colônia, do empregador sobre o empregado. O que se observa é que a defesa da permanência no local de trabalho afirmando-se que o trabalho presencial cria vínculos e traz benefícios para a equipe esconde a questão do controle que se quer exercer sobre o trabalhador, impedindo surgir 0 comprometimento e tornando as relações empobrecidas em um nível maior de impacto tanto na força de trabalho como na totalidade do processo produtivo, já comprido espacial, acelerado temporalmente e potencializado informacional e financeiramente 
antes da chegada da pandemia (HAESBAERT, 2020). Cabe recordar que a ideia de controle está muito presente no pensamento que norteia as relações de trabalho na América Latina, justamente em decorrência desse pensamento colonial, que envolve domínio e poder, e que vem acompanhado dessa tecnicidade que valora as relações sob uma escala de produtividade acima de tudo em um alinhamento entre saber, poder e fazer que perfaz e sintetiza o percurso produtivo e de conhecimento da colonialidade. Nessa escala de produtividade, o ser humano faz parte desta lógica produtiva como uma engrenagem a mais, conforme destacado anteriormente, e como parte dessa engrenagem, deve estar devidamente controlado, por diferentes dispositivos, práticas e discursos, para que tudo ocorra conforme o previsto inicialmente, no planejamento, e a máquina produtiva possa 'girar' sem interrupções e com ritmo e harmonia. Relembra muito Gareth Morgan (1996) a ideia de mecanização assumindo o comando das organizações e, por que não, da vida no mundo do trabalho, reforçando-se ainda mais a colonialidade do poder?

\subsection{PANDEMIA E CONTROLE - COMO FICA ESSA RELAÇÃO?}

A pandemia do novo coronavírus, Sars CoV-2, teve seus primeiros casos documentados ainda nos últimos meses de 2019. A enfermidade advinda do contágio com o vírus ficou mundialmente conhecida como COVID-19, com sintomas iniciais próximos a de uma gripe com acréscimo de febre, mas com possibilidades de agravamento do quadro de saúde em poucos dias (JOHNS HOPKINS UNIVERSITY, 2020). Pela falta de um tratamento efetivo ou profilaxia específica para o novo coronavírus houve, de imediato medidas de isolamento ou distanciamento social como formas de diminuição tanto do contágio como óbitos causados pela COVID-19, enquanto diferentes iniciativas de desenvolvimento de vacinas foram colocadas em prática e, posteriormente, com ações de imunização a partir dos primeiros meses de 2021.

A relação entre a pandemia e a inteligência artificial e, por continuidade, ao mundo informacional, ocorreu devido às ações de distanciamento e isolamento social no mundo do trabalho, na mobilidade de pessoas e mercadorias nas estratégias didático-pedagógicas, na produção de entretenimento etc. É a partir de tais impactos que é possível, atualmente, avaliar a maneira como a pandemia do novo coronavírus adiantou em anos, ou décadas, a presença e impactos da ausência, do mundo 
informacional, robótico e altamente tecnológico nas relações sociais (AGUILAR CASTRO; TERÁN VILLEGAS, 2021).

Com a pandemia, essa forma de controle perde potência formal, mas adquire outras formas de pressão. O que se observa no período pandemia e pós-pandemia é que as pessoas não estão controlando seu tempo; ao contrário, as empresas estão buscando formas cada vez mais eficientes de procurar verificar o que o funcionário está fazendo em sua casa e o conceito de tempo de trabalho e tempo de não trabalho está ficando cada vez mais misturado, as chamadas para reuniões de videoconferência ocorrem com cada vez mais frequência, pacotes de internet e de sistemas de teleconferência são cada vez mais acionados, causando mais estresse e reduzindo a saúde mental - e física - do trabalhador. Cumpre relembrar que quando o controle é a forma preponderante na relação de trabalho empregador-empregado, não há espaço para a construção de uma relação de confiança, que gere o comprometimento. Tampouco há espaço para que se encontre, no trabalho, espaços para a construção do ser humano. E, particularmente no que se refere ao fator socioespacial dos impactos da COVID-19, como destaca Haesbaert (2020) e Davis (2020), há diferentes dimensões pelas quais é possível imergir, analítica e criticamente, sobre os efeitos deste impacto, de forma distinta e, em alguns casos, seletiva, ao redor do mundo. A América Latina está passando por um momento delicado de diferenciação das ações e discursos, internos e externos, no que se refere a tais impactos da pandemia na complexidade humano como fator inerente ao processo produtivo capitalista.

Há, na pandemia, uma ruptura das relações sociais, causadas pelo isolamento. Se a função econômica do trabalho, voltada à satisfação das necessidades de subsistência do indivíduo, tornou-se praticamente única, levando a uma perda da construção do sentido do trabalho para quem o executa, com a pandemia, ela se reforça. A função social, que é a que traz o sentido de pertencer, fica ausente ou bem prejudicada nessa nova relação do ser humano com a atividade que executa e, em tempos póspandemia, fica praticamente inexistente. Com a pandemia, os reduzidos espaços para a construção do ser, no ambiente de trabalho, ficarão ainda mais escassos; o tempo do não trabalho ficará cada vez mais reduzido e desvalorizado; a tendência é de o ser humano trabalhar mais, sem a separação do tempo do trabalho e do tempo do lazer. 
Com o aumento do nível de estresse, as demissões e fechamentos de empresas, a redução de possibilidades de trabalho, os indivíduos em pós-pandemia passam a sofrer uma grande pressão para sucumbir ao controle e às novas formas de trabalho exigidas pelas empresas. O processo de flexibilização do processo produtivo foi potencializado pela pandemia, mas não é exclusivo de seu agregado de impactos socioeconômicos. Tal como destaca Harvey (1996, p. 140): “O trabalho organizado foi solapado pela reconstrução de focos de acumulação flexível em regiões que careciam de tradições industriais anteriores e pela reimportação para os centros mais antigos das normas e práticas regressivas estabelecidas nessas novas áreas." e mais recentemente, em sua versão 4.0, o modo de produção capitalista financeiro, estético e informacional atinge o que Floridi (2014) chama de estado onlife de produção, circulação e consumo, em uma evolução ao que, até poucos anos atrás, atingiu particularmente a administração produtiva pelo just in time de conglomerados internacionais.

A falta de socialização advinda do isolamento vai tornando o trabalho ainda mais árduo e sem calor humano; aquele conceito do trabalho como um elemento de construção do ser, de permitir às pessoas se sentirem respeitadas e reconhecidas, ao se sentirem realizadas nas funções que exercem, bem como ao alcançarem reconhecimento dos pares e/ou dos superiores, tem se tornado mais tênue. O controle de produção e consumo e, de forma equivalente, da flexibilização ou eventuais extinções de diretrizes trabalhistas e produtivas também fazem parte de um ritmo acelerado de transformações elevadas pela pandemia, mas como apresentado, fazem parte de um fluxo de situações e posicionamentos de circunstâncias, especificamente, alinhados ao contexto pandêmico em nível global e, em alguns aspectos, selecionados à realidade latino-americana.

\section{CONSIDERAÇÕES FINAIS}

Como apresentado nesta pesquisa, o trabalho exerce uma centralidade na vida das pessoas que vai além de uma satisfação econômica de suas necessidades. A estrutura desta pesquisa deriva dessas diversas funções do trabalho e de sua associação com a Administração e o Direito, mais especificamente o Direito do Trabalho, ampliando os estudos já realizados, os quais demonstram que essas áreas de conhecimento têm reforçado somente o lado ter da relação trabalhista, não contribuindo para que o ser 
humano possa ser, no trabalho, ou seja, tenha o trabalho como um meio de formação integral e de construção e manutenção de sua dignidade.

O papel da América Latina no arranjo econômico capitalista global segue seu curso, em novas modulações produtivas e de consumo. A era informacional, agora mais vívida que nunca, foi condicionada a desvelar-se ainda em mais formas de si mesma durante a pandemia da COVID-19, em seu trajeto de expansão e desenvolvimento ao longo das últimas décadas. Entre ações e contradições, discursos e práticas, conhecimentos e formas de consumo, assiste-se a uma continuidade da dualidade colonial pelas vestes socioeconômicas do desigual e complexo sistema capitalista de produção.

Com relação à questão de pesquisa ora apresentada, sobre qual o impacto das instituições Administração e Direito do Trabalho, estruturadoras das relações sociais nas organizações, após a ruptura do modo tradicional de execução do trabalho com a póspandemia, identifica-se que o trabalho ainda se mantém como uma das principais categorias de construção do ser em sua integralidade, e que os principais desafios que se apresentam para a Administração e para o Direito do Trabalho estão em quebrar as amarras seculares que derivam de uma visão de colonialidade do poder, que busca o controle acima do comprometimento, para se transformarem em apoiadores do processo de edificação integral do ser humano tendo o trabalho como um dos principais alicerces.

Enquanto essa quebra não ocorre, a Administração e o Direito do Trabalho mantêm um papel mais de desconstrutores do sentido do ser no trabalho, faltando, ainda, a estruturação de um novo modus operandi que contribua para que o ser humano tenha, no trabalho e com o trabalho, real possibilidade de ser e de se desenvolver, de forma mais completa e digna, por meio de sua ação sobre o meio em que vive.

\section{REFERÊNCIAS}

AGUILAR CASTRO, Jose Lisandro; TERÁN VILLEGAS, Oswaldo Ramón. COVID-19 y sus implicaciones sociales: una mirada desde las ciencias computacionales. Educere: Revista Venezolana de Educación, n. 80, p. 147-164, 2021. Disponível em: < http://erevistas.saber.ula.ve/index.php/educere/article/view/16467> Acesso em 25 jun. 2020. 
ASSIS, Wendell Fischer Teixeira. Do colonialismo à colonialidade: expropriação territorial na periferia do capitalismo. Cadernos CRH, Salvador, v. 27, n. 72, p. 713-627, set/dez 2014

BRASIL. Lei no 13.467, de 13 de julho de 2017. Diário Oficial da União, Brasília, DF, 14 jul.2017. Disponível em: <http://www.planalto.gov.br/ccivil_03/_ato20152018/2017/lei/l13467.htm>. Acesso em 24 mai.2020.

DATHEIN, Ricardo. Inovação e Revoluções Industriais: uma apresentação das mudanças tecnológicas determinantes nos séculos XVIII e XIX. Publicações DECON. Textos Didáticos 02/2003. DECON/UFRGS, Porto Alegre, fev. 2003.

DAVIS, Mike, etalii. Coronavírus e a luta de classes. Terra sem Amos: Brasil, 2020. Disponível em: $<$ https://terrasemamos.files.wordpress.com/2020/03/coronavc3adrus-e-a-lutade-classes-tsa.pdf>.Acesso em 22 jul.2020.

DUPLEIX, François; QUINET, Ferdinand; MARLY, Jean; SCHETTEL, Adrien ; BEAUMONT, Jean Henri de. Sobre a maquinaria e seus efeitos. In: MUSTO, Rubens. Trabalhador, uni-vos!: analogia política da I Internacional. 1a ed. São Paulo: Boitempo, 2014. Cap. 5, p. 118-119.

FARAH JUNIOR, Moisés Francisco A Terceira Revolução Industrial e o Novo Paradigma Produtivo: Algumas Considerações sobre o Desenvolvimento Industrial Brasileiro nos Anos 90. Rev. FAE, Curitiba, v.3, n.2, p.45-61, maio/ago. 2000.

FLORIDI, Luciano. The 4th Revolution: How the infosphere is reshaping human reality. Oxford University Press, 2014.

GOLDIN, Adrián (org.). Curso del Derecho del Trabajo y la Seguridad Social. 1 ed. Buenos Aires: La Ley, 2009.

HAESBAERT, Rogério. Entre a contenção e o confinamento dos corpos-território: reflexões geográficas em tempos de pandemia (I) e (II). AGB-Campinas, 24.03.2020. Disponível em: <http://agbcampinas.com.br/site/2020/rogeriohaesbaert-desterritorializacaosem-limites-reflexoes-geograficas-em-temposde-pandemia-i/>. Acesso em 20 jul.2020.

HARVEY, David. A condição pós-moderna. Trad. Adail Ubirajara Sobral e Maria Stela Gonçalves. São Paulo: Edições Loyola, 1996.

HEGEL, Guillermo Federico. Filosofía del Derecho. Prólogo de Carlos Marx. 5. ed. Trad. Angélica Mendoza de Montero. Buenos Aires: Editorial Claridad, 1968.

HEGEL, Georg Wilhelm Friedrich. Fenomenologia do espírito. Tradução de Paulo Meneses; com a colaboração de Karl-Heinz Efken e José Nogueira Machado. 3. ed. rev. Petrópolis, RJ: Vozes; Bragança Paulista: Editora Universitária São Francisco, 2005. 
JOHNS HOPKINS UNIVERSITY. Coronavirus COVID-19 global cases by Johns Hopkins CSSE. Coronavirus Resource Center. COVID-19 Dashboard by the Center for Systems Science and Engineering (CSSE) at Johns Hopkins University (JHU) -Map. Disponível em: <https://coronavirus.jhu.edu/map.html>. Acesso em: jun. 2020.

LANDER, Edgardo (org). La colonialidad del saber. Eurocentrismo y Ciencias Sociales. Perspectivas Latinoamericanas. Buenos Aires: CLACSO, 2003.

MORGAN, Gareth. Imagens da organização. Tradução: Cecília Whitaker Bergamini e Roberto Coda. São Paulo: Atlas, 1996.

NASCIMENTO, Amaury Mascaro. Iniciação ao Direito do Trabalho. 32 ed. rev. e atual. São Paulo: LTr, 2006.

NAVA GUIBERT, Luis. El trabajador migrante andino. Derechos y beneficios laborales en Perú, Bolivia, Colombia e Ecuador. 1 ed. Lima: USMP Universidad San Martín de Porres/Fondo Editorial, 2020.

QUIJANO, Aníbal. Modernidad, Identidad y Utopia en América Latina. Lima: Sociedad y Política Ediciones, 1988.

MARX, Karl; ENGELS, Friedrich. A ideologia alemã e outros escritos (primeira parte); selecionados por Octavio lanni; traduzidos por Waltensir Dutra e Florestan Fernandes. Rio de Janeiro: Zahar Editores, 1965.

MARX, Karl; ENGELS, Friedrich. A ideologia alemã. [introdução de Jacob Gorender]; tradução Luis Claudio de Castro e Costa. São Paulo: Martins Fontes, 1998. (Clássicos).

MARX, Karl. O Capital: Crítica da economia política. Livro I: O processo de produção do capital. Trad. Rubens Enderle. São Paulo: Boitempo, 2013.

MAXIMIANO, Antonio Cesar Amaru. Introdução à teoria geral da administração. 3o ed. São Paulo: Atlas, 2015.

MIRAGLIA, Livia Mendes Moreira. O direito do trabalho e a dignidade da pessoa humana - pela necessidade de afirmação do trabalho digno como direito fundamental. Anais do XIX Encontro Nacional do CONPEDI realizado em Fortaleza - CE nos dias 09, 10, 11 e 12 jun.2010, p. 9038-9047.

STEENS, Eugène. Os efeitos da maquinaria sobre o salário e a situação dos trabalhadores. In: MUSTO, Rubens. Trabalhador, uni-vos!: analogia política da I Internacional. 1ạ ed. São Paulo: Boitempo, 2014. Cap. 8, p. 124-128.

TARTARET, Eugène. Pela redução das horas de trabalho. In: MUSTO, Rubens. Trabalhador, uni-vos!: analogia política da I Internacional. 1a ed. São Paulo: Boitempo, 2014. Cap. 10, p. 132-134. 
SANSON, Cesar. Quarta Revolução Industrial. Revolução 4.0. 2017. Disponível em: <http://www.ihu.unisinos.br/images/ihu/apresentacoes_palestrantes/30_05_1 7_cesar_sanson_revolucao_4.0.pdf >. Acesso em 24 mai.2020.

TAMASHIRO, Ricardo de Melo; GANAKA, Cristiane; CARDOSO, André. Resenha: A quarta revolução industrial / Klaus Schwab; tradução Daniel Moreira Miranda - São Paulo: EDIPRO, 2016. Revista Ciências do Trabalho, n. 9, p. 127-134, dezembro de 2017.

TEIXEIRA, João de Fernandes. Mentes e Máquinas: Uma Introdução à Ciência Cognitiva. 1. ed. Porto Alegre: Artes Médicas, 1998.

ZUBOFF, Shoshana. The Age of Surveillance Capitalism: The Fight for a Human Future at the New Frontier of Power. New York: PublicAffairs, 2019 


\title{
CAPITULO XIV
}

\section{A TEORIA ARGENTINA DE ENRIQUE DEL PERCIO SOBRE MUDANÇAS NA SOCIEDADE CONTEMPORÂNEA E A INFLUÊNCIA DESTAS NO ENVELHECIMENTO DO PERFIL DEMOGRÁFICO POPULACIONAL NA AMÉRICA LATINA}

DOI: 10.51859/AMPLLA.EDL1037-14

Thiago Barros de Siqueira ${ }^{1}$

\begin{abstract}
${ }^{1}$ Professor de Direito Previdenciário. Membro do Corpo Docente da Pós-Graduação em Direito Previdenciário da Faculdade Damásio. Mestre em Direito Previdenciário pela Pontifícia Universidade Católica de São Paulo - PUC/SP e Especialista em Direito Público habilitado ao Magistério Superior pela Escola Paulista de Direito - EPD. Chefe de Divisão do Escritório Regional São Paulo da Superintendência Nacional de Previdência Complementar - PREVIC. Exmembro da Câmara de Recursos da Previdência Complementar - CRPC.
\end{abstract}

\section{RESUMO}

Os países da América Latina, entre eles a Argentina e o Brasil, têm experimentado um crescente movimento de envelhecimento do seu perfil populacional, o que decorre de sucessivas quedas nas taxas de natalidade e aumentos na expectativa de vida das pessoas. Esse movimento demográfico, tratado por alguns como "onda idosa", decorre de profundas mudanças na sociedade, em processo que foi muito bem explorado pelo professor e filósofo argentino Enrique del Percio, o qual soube analisar as alterações estruturais na sociedade ao longo dos anos, principalmente no que diz respeito ao papel das mulheres, que foi determinante para o panorama de envelhecimento vivido atualmente. $O$ presente artigo é fruto das pesquisas científicas realizadas no âmbito do crédito de Derecho y Sociedad, no primeiro módulo do Programa de Actualización en Ciencias Jurídicas Válido para el Doctorado, da Universidad de Buenos Aires - UBA, ministrado pelo citado professor, em conjunto com a experiência do autor de quase 15 (quinze) anos trabalhando no Sistema de Seguridade Social Brasileiro, bem como estudando a proteção à idade avançada no Brasil.

Palavras-chave: Sociedade. Envelhecimento. Demografia. América Latina. 
A análise do perfil demográfico da população da América Latina, especialmente da Argentina e do Brasil, denota a configuração de um movimento de transição ${ }^{1}$ ou de "virada demográfica" 2 , onde verifica-se que os países latinos estão deixando de serem países jovens para terem maioria de cidadãos adultos e idosos ${ }^{3}$.

Na Argentina, no ano de 1980, as pessoas com sessenta anos de idade ou mais eram equivalentes a 8,2\% da população. No entanto, previsões do Instituto Nacional de Estadística y Censos - INDEC ${ }^{4}$ indicam que no ano de 2030 essa porcentagem será de 17,51\% da população (8.653.894 idosos), e no ano de 2040 atingirá a marca de 20,59\% (10.870.882 idosos).

Por sua vez, no Brasil, no ano de 1980, as pessoas com sessenta anos de idade ou mais eram equivalentes a $6,07 \%$ da população. Previsões do Instituto Brasileiro de Geografia e Estatística - IBGE 5 indicam que no ano de 2030 essa porcentagem será de 18,70\% da população (40.472.804 idosos), e no ano de 2050 essa parcela da população será de quase $30 \%$ (64.050.980 idosos).

A "onda idosa"6 que toma conta do continente latino decorre fundamentalmente de dois fatores distintos: de um lado do envelhecimento da população e, de outro, de uma expressiva queda nas taxas de natalidade, fruto de mudanças sociais vividas em todo o mundo.

No que tange ao envelhecimento da população na América Latina, este processo acompanha uma tendência mundial que decorre, por sua vez, de uma melhora geral nas condições de vida das pessoas (direitos sociais, saneamento básico, educação, dentre outros) e do desenvolvimento das ciências médicas.

\footnotetext{
${ }^{1}$ Ensina Lourdes Lopez Cumbre que "se utiliza la expressión 'transición demográfica' para designar un período de fuerte crecimiento de la población, debido al prolongado y marcado decenso de las tasas de mortalidad y de natalidad”. in LÓPEZ CUMBRE, Lourdes. (Coord) Tratado de jubilación. Homenaje a Luis Enrique de la Villa Gil Madri: Iustel, 2007, p. 97.

${ }^{2}$ MINISTÉRIO DA PREVIDÊNCIA SOCIAL. Envelhecimento e dependência: desafios para a organização da proteção social. Coleção Previdência Social, v.28. Brasília, 2008, p. 118.

${ }^{3}$ Propõe Maldonado Molina que "debe abrirse una auténtica interrelación entre sociedad y ancianos, porque ámbos se necesitan mutuamente, y ahora más que en ningún otro momento de la Historia de la Humanidad, en que por primera vez la vejez representa un escalón destacado en la estructura demográfica". op. cit., p. 106.

${ }^{4}$ INSTITUTO NACIONAL DE ESTADÍSTICA Y CENSOS. Estimaciones y proyeciones de población 2010-2040. Ciudad Autónoma de Buenos Aires, 2013.

5 INSTITUTO BRASILEIRO DE GEOGRAFIA E ESTATísTICA. Projeção da população do Brasil por sexo e idade - 1980 - 2050. Revisão 2008. Rio de Janeiro, 2008.

6 TAFNER, Paulo; GIAMBIAGI, Fabio (orgs.). Previdência no Brasil: debates, dilemas e escolhas. Rio de Janeiro: IPEA, 2007, p. 96.
} 
Estudos revelam a estimativa de que a expectativa de vida na época do Império Romano era de apenas 25 anos $^{1}$, sendo que quase dois milênios depois, no ano de 1940, esse valor nem sequer chegou a dobrar, atingindo a baixa marca de 45,5 anos no Brasil ${ }^{2}$.

Contudo, a comparação deste precedente dado com o do corrente ano de 2020 revela, nos últimos oitenta anos, um aumento na esperança de vida da população maior do que o experimentado pelo mundo nos últimos dois milênios, já que a expectativa de vida aumentou mais de 31 anos, atingindo a marca de 76,1 anos no Brasil e 78,07 anos na Argentina ${ }^{3}$.

Se de um lado as pessoas na América Latina estão vivendo mais, de outro as suas famílias estão tendo cada vez menos filhos, em decorrência de uma expressiva queda nas taxas de natalidade/fecundidade, o que está levando ao inevitável desenho de um perfil demográfico envelhecido, com mais idosos e menos crianças.

No ano de 2020, a taxa de fecundidade na Argentina foi de 2,18 filhos por mulher, sendo que previsões indicam que esse número será de apenas 1,98 no ano de $2040^{4}$.

No Brasil esse panorama é ainda mais alarmante, na medida em que a taxa de fecundidade partiu de 6 filhos por mulher, até a década de 1960, para atingir 1,76 no ano de 2020 , com previsão de atingir a marca de 1,69 no ano de $2040^{5}$.

Com relação a este fenômeno de queda nas taxas de natalidade, que contribui para o envelhecimento do perfil demográfico da América Latina, tal movimento decorre de profundas mudanças na sociedade contemporânea, em processo descrito de forma didática pelo filósofo argentino Enrique del Percio ${ }^{6}$, cuja teoria utilizamos para demonstrar o contexto que foi determinante e ainda interfere no estágio atual de envelhecimento populacional.

\footnotetext{
${ }^{1}$ LÓPEZ CUMBRE, Lourdes. (Coord) Tratado de jubilación. Homenaje a Luis Enrique de la Villa Gil Madri: lustel, 2007, p. 119.

2 INSTITUTO BRASILEIRO DE GEOGRAFIA E ESTATÍ́STICA. Projeção da população do Brasil por sexo e idade - 1980 - 2050. Revisão 2008. Rio de Janeiro, 2008.

3 Idem.

${ }^{4}$ INSTITUTO NACIONAL DE ESTADÍSTICA Y CENSOS. Estimaciones y proyeciones de población 2010-2040. Ciudad Autónoma de Buenos Aires, 2013

https://agenciadenoticias.ibge.gov.br/agencia-sala-de-imprensa/2013-agencia-denoticias/releases/21837-projecao-da-populacao-2018-numero-de-habitantes-do-pais-deve-parar-decrescer-em-2047

${ }^{6}$ Reitor da Universidad de San Isidro, na Argentina. Diretor do Doutorado em Filosofia da Universidad del Salvador, sede San Miguel. Codiretor do Programa Internacional de Estudios sobre Democracia, Sociedad y Nuevas Economías, da Universidad de Buenos Aires - UBA. Professor de sociología jurídica y de la dominación da Universidad de Buenos Aires - UBA.
} 
Num passado remoto, as sociedades, inclusive na América Latina, eram mais rígidas, com pouca mobilidade social e quase nenhuma possibilidade de escolha acerca de questões laborais ou matrimoniais.

Quanto ao trabalho remunerado, o mesmo era exercido pelo homem, que normalmente herdava o mesmo ofício do pai, ou seja, o filho do sapateiro provavelmente também o seria, por exemplo.

O homem era considerado o provedor e comandante da família, devendo todos, filhos e esposa, obedecerem a sua vontade e os seus comandos. Era impensável a ideia, dominante atualmente, de igualdade entre homens e mulheres, especialmente no âmbito de um casamento, que se pautava pela submissão da mulher ao homem.

Não era comum que as mulheres trabalhassem fora de casa, cabendo a elas o papel de reprodutoras e de cuidadoras da casa e da família, principalmente das crianças e dos idosos. Sequer podiam optar sobre seu matrimonio, normalmente definido pelo seu pai.

Um contexto de guerras e necessidade de mão de obra para o trabalho exigia das mulheres a concepção de muitos filhos, dos quais nem todos sobreviviam face às altas taxas de mortalidade infantil do passado. Assim, pode-se dizer que as mulheres eram verdadeiras reprodutoras de soldados e operários, necessários para morrer na guerra ou trabalhar nas indústrias.

O papel das mulheres na sociedade era marcado por muita submissão e opressão, não sendo incomum terem de suportar agressões de seus maridos, em um quadro de relacionamentos abusivos e possessivos. Enfim, as mulheres viviam para atender as necessidades dos maridos e dos filhos.

Nesse panorama, no passado, considerando os papeis pré-determinados de homens e mulheres, pode-se dizer que a vida em sociedade era mais estável, ou imutável. Normalmente o pai provedor trabalhava a vida toda em um único ofício e a família residia a vida toda em um mesmo e único local.

Esta certa estabilidade ou imutabilidade social propiciava maior vínculo da família com a comunidade local, sua base de apoio, sendo padrão, à época, conhecer e ter vínculos duradouros com vizinhos e colegas de trabalho.

Nesse contexto de sociedade, à época já em transição, é que se explica, no Brasil, até a década de 1960, a taxa de fecundidade estimada em valor ligeiramente superior a 
6 filhos por mulher em idade reprodutiva ${ }^{1}$, índice este possivelmente maior nos anos anteriores, não oficialmente mensurados.

Este panorama, antes consolidado, passou a se alterar a partir do século XVII com a consolidação de um modelo de Estado Nacional Moderno, que alicerçou a burguesia no centro da estrutura social, com a transição de um modelo de estratificação social estamental (determinado pela origem familiar) para um modelo de estratificação social por classes (determinado pela posse de riquezas).

Mais recentemente, a partir da década de 1970, num contexto de neoliberalismo, a mudança de um capitalismo de acumulação para um capitalismo de consumo, com o advento de novas tecnologias informáticas e de comunicação, bem como com a expansão do crédito para o consumo, foram fatores que implicaram mudanças que refletem na conformação da sociedade até os dias de hoje.

Pode-se dizer que a década de 1970 foi um marco para esta transição e conformação do atual modelo de sociedade, na medida em que foram anos marcados pela Crise do Petróleo e por desenvolvimento tecnológico que levou a um incremento de produtividade nunca visto antes, que passa a exigir o correspondente incremento do consumo.

Após o desenho deste panorama, Del Percio, em sua teoria, identifica três principais espécies de mudanças, nos âmbitos laboral, residencial e doméstico, que foram fundamentais para a conformação atual da sociedade.

No âmbito laboral, se no passado era comum e desejoso trabalhar a vida inteira em uma única e mesma empresa, após os anos de 1970, com o advento contínuo de novas tecnologias, esse panorama se altera, hoje não sendo bem visto um trabalhador nessas condições, sendo o novo padrão trabalhar em diversas empresas ao longo de sua vida laboral, o que prejudica a consolidação de vínculos de amizade duradoura com os colegas de trabalho.

No âmbito residencial, surge uma necessidade maior de mudanças de endereço, para próximo dos locais de trabalho ou para viver em um espaço mais adequado com os estilos de vida, razão pela qual também não se consolidam vínculos de amizade duradoura com os vizinhos.

\footnotetext{
${ }^{1}$ INSTITUTO BRASILEIRO DE GEOGRAFIA E ESTATÍ́STICA. Projeção da população do Brasil por sexo e idade - 1980 - 2050. Revisão 2008. Rio de Janeiro, 2008.
} 
Por fim, no âmbito doméstico, considerando a alta produtividade decorrente do emprego das novas tecnologias, que requerem maior consumo de produtos com alto valor agregado, exige-se que as mulheres trabalhem fora para dobrar a renda (e o consumo), e, consequentemente, tenham cada vez menos filhos, cujo custo de criação impede o consumo de outros bens.

De outro lado, o trabalho das mulheres fora do ambiente doméstico permite uma maior interação entre homens e mulheres nos mais diversos ambientes (ruas, fábricas, escritórios), o que acaba permitindo a busca da felicidade, pelo casal, fora de casa e, consequentemente, leva a uma fragilização (crise) dos matrimônios, anteriormente indissolúveis.

Em outras palavras, a inserção da mulher no mercado de trabalho, fora do âmbito domiciliar, permitiu maior contato entre homens e mulheres, possibilitando a ambos uma maior chance de encontrar um par que lhes faça felizes, o que contribuiu para alterações no perfil familiar, antes imutável.

Há que se registrar, além disso, que contribui para uma mudança no perfil tradicional de família novas alternativas decorrentes da homossexualidade, da masturbação e do controle de natalidade. Atualmente, muitos jovens optam por viver sozinhos para não enfrentar os desafios de uma estrutura familiar tradicional.

Nesse contexto, percebe-se que as mudanças na sociedade têm como ponto fulcral a necessidade de consumo, que favorece o ideal capitalista norte-americano conhecido por DINKs: Double Income, No Kids (Renda em Dobro, Sem Crianças).

Em outras palavras, a ideia de DINKs determina que, para consumir, as famílias precisam ter mais renda, o que impõe o trabalho remunerado também pela mulher, $\mathrm{e}$ menor número, ou nenhum, de filhos, para que sobre dinheiro para financiar esse consumo de bens de alto valor agregado, como automóveis, aparelhos celulares, televisores e computadores.

Desta forma, no novo contexto econômico e social, a mulher deixa de ser exclusivamente mãe, assim como o homem deixa de ser unicamente o pai provedor.

Portanto, o atual modelo de família, e as relações sociais que a permeiam no âmbito laboral e residencial, mostram-se mais instáveis se comparadas ao modelo anterior. A sociedade evolui de um contexto de certezas imutáveis, nem sempre agradáveis, para um panorama de incertezas angustiantes. 
Diferentemente do modelo anterior, hoje homem e mulher têm a liberdade de escolher uma profissão, de definir com quem vão se casar e quantos filhos vão ter, e a resposta a esses questionamentos pode vir acompanhada de certa medida de sofrimento, uma vez que são questões difíceis e importantes, que determinarão a vida da pessoa.

Se por um lado esse novo modelo de família se mostra mais paritário entre o casal, de outro passa-se a ter cada vez menos filhos, sendo muito comum famílias com filhos únicos. Portanto, mudamos diametralmente de uma sociedade com famílias extensas para uma sociedade de filhos únicos.

No novo contexto tecnológico e social que se impõe, que prescinde de grande contingente populacional, a mulher deixa de ser mera reprodutora de soldados e operários, consumidos pelas guerras ou pela indústria, como engrenagens de um sistema.

Em se tratando de filho/neto único, toda a atenção da família volta-se com exclusividade à criança, que para manter essa atenção enquanto cresce, recorre às redes sociais, mostrando-se (e o que consome) em busca de seguidores e aprovação (likes).

Nesse contexto de superficialidade das relações, também em decorrência da hiperconectividade que não permite o seu aprofundamento, não se conhece verdadeiramente o outro, mas apenas o que o outro se permite mostrar, principalmente o que consome, sendo as pessoas valoradas em função disso.

O dinamismo próprio da sociedade de consumo não permite conhecer a trajetória ou história pessoal do outro. Apenas conhecemos aquilo que o outro mostra: roupas, viagens, carro, casa, ou seja, apenas conhecemos o que o outro consome.

Portanto, consolida-se uma geração de narcisistas, que é valorada pelo que se mostra, tendo mais valor a aparência e o consumo do que o seu conteúdo (valores e sentimentos).

Voltando-se para a temática da idade avançada (velhice), o contexto narrado traz um perigoso e complexo paradoxo a ser enfrentado. Se de um lado o neoliberalismo é, em sua essência, o fundamento teórico para as mudanças sociais pautadas por um maior individualismo, de outro o seu ideal de Estado Mínimo impõe a diminuição ou supressão de benefícios e serviços públicos de saúde. Nesse contexto, nasce um questionamento: quem cuidará dos idosos e dará suporte aos doentes no âmbito de um pretendido 
Estado Mínimo, já que hoje a família, os vizinhos e os amigos não representam mais a mesma base de apoio existente no passado?

Nesse ponto, observamos uma aviltante incompatibilidade entre o atual modelo de sociedade e o ideal neoliberalista de Estado Mínimo, que pressupõe a diminuição e supressão dos benefícios e serviços públicos de saúde, em um contexto de inexistência de base de apoio e suporte familiar, anteriormente liderada pela mulher com exclusividade no âmbito doméstico.

As consequências desse paradoxo deverão ser observadas, em breve, na qualidade de vida dos idosos e no próprio perfil demográfico da população na América Latina, na medida em que se aprofundam, de um lado a privatização dos benefícios e serviços de saúde, e de outro o individualismo nos âmbitos residencial, laboral e doméstico.

Enfim, o inexorável processo de envelhecimento da população na América Latina implica a necessidade inadiável de adequação das políticas públicas sociais, especialmente as de saúde, previdência e assistência social, à nova realidade social e demográfica do continente.

\section{AGRADECIMENTOS}

Agradecimento ao inspirador e estimado Professor Enrique del Percio, a quem tive a honra de conhecer e ser aluno, na Argentina, no crédito de Derecho y Sociedad, no primeiro módulo do Programa de Actualización en Ciencias Jurídicas Válido para el Doctorado, da Universidad de Buenos Aires - UBA.

\section{REFERÊNCIAS}

DEL PERCIO, Enrique. ECONOMÍA, POLÍTICA Y CULTURA - Esquema de la estructura de dominación contemporánea. Acesado en https://uba.academia.edu/EnriqueDelPercio.

Seguridad Sustentable y Estructura de Dominación. Acesado en https://dialnet.unirioja.es/descarga/articulo/2329929.pdf.

- Motivaciones políticas y sociales del renovado interés por la filosofía de la liberación y otras concepciones afines. Tendencia Sociales, Revista de Sociología, 1 (2018): 119-142. Facultad de Ciencias Políticas y Sociología UNED. Acesado en https://uba.academia.edu/EnriqueDelPercio. 
DEMOCRACIA SIN PUEBLO: PROBLEMAS DE LEGITIMACIÓN EN EL NEOLIBERALISMO TARDÍO. iVS fVGIT, 21, 2018, PP. 55-74. Acesado en https://uba.academia.edu/EnriqueDelPercio.

- LA AGONÍA DE LOS DERECHOS HUMANOS: FRATERNIDAD Y DEMOCRACIA RADICAL. Acesado en https://revistacontemporanea.faficape.edu.br/index.php/contemporanea/article/view/14.

- Los derechos reproductivos, el capitalismo tardío y el último hombre. Acesado en https://uba.academia.edu/EnriqueDelPercio.

Acesado Argentina: The Philosophical Resistance to the Conquest of the Soul. https://www.oapen.org/download?type=document\&docid=1004913.

INSTITUTO BRASILEIRO DE GEOGRAFIA E ESTATÍSTICA. Projeção da população do Brasil por sexo e idade - 1980 - 2050. Revisão 2008. Rio de Janeiro, 2008.

INSTITUTO NACIONAL DE ESTADÍSTICA Y CENSOS. Estimaciones y proyeciones de población 2010-2040. Ciudad Autónoma de Buenos Aires, 2013.

LÓPEZ CUMBRE, Lourdes. (Coord) Tratado de jubilación. Homenaje a Luis Enrique de la Villa Gil Madri: Iustel, 2007.

MINISTÉRIO DA PREVIDÊNCIA SOCIAL. Envelhecimento e dependência: desafios para a organização da proteção social. Coleção Previdência Social, v.28. Brasília, 2008, p. 118.

TAFNER, Paulo; GIAMBIAGI, Fabio (orgs.). Previdência no Brasil: debates, dilemas e escolhas. Rio de Janeiro: IPEA, 2007. 


\section{CAPITULO XV}

\section{CRIAÇÃO, ANÁLISE, INTERPRETAÇÃO E CONSTRUÇÃO DOS DIREITOS \\ HUMANOS PASSADOS E FUTUROS A PARTIR DA REVITALIZAÇÃO E DA IMPORTÂNCIA DA LÍNGUA ESPANHOLA}

Rilke Rithcliff Pierre Branco ${ }^{1}$

${ }^{1}$ Doutorando em Direito pela Universidade de Buenos Aires (UBA), Mestre em Direito e Negócios Internacionais pela Universidad Europea del Atlántico (UNEATLÁNTICO), professor universitário, formado em Direito, História e Pedagogia, com 12 pós graduações na área de Ciências Jurídicas e Sociais e outras 8 especializações no ramo da Educação.

\section{RESUMO}

O artigo prestou-se a fazer uma síntese historiográfica da relevância do uso da língua hispânica no centro dos principais "direitos passados e futuros", acentuando os pontos de similaridade dos valores culturais atuais até à formação de blocos supranacionais e de alianças em comum. Neste passo, propõe-se uma reflexão sobre a posição de assimilação do castelhano à educação política, jurídica e econômica das próximas gerações, e a sua constante retroalimentação.

Palavras-chave: Direitos humanos. Língua espanhola. História.

\section{RESUMEN}

Este artículo quiso hacer una síntesis de la historiografía y de la relevancia del uso de la lengua hispánica en el centro de los principales "derechos futuros", acentuando los puntos de semejanza entre los valores culturales hasta la formación de bloques supranacionales y de alianzas comunes en la actualidad. Así, propone una reflexión del aprendizaje del español en la educación jurídica de las próximas generaciones y su retroalimentación.

Palabras-clave: Derechos humanos. Lengua española. Historia. 


\section{INTRODUÇÃO}

Os povos e os Estados latino-americanos apresentam semelhanças que vão além do campo ideológico e cultural. Na hipótese, estudar-se-á a produção e evolução histórica dos direitos políticos, econômicos e sociais a partir da relevância da língua espanhola na região.

Sob este ângulo, o artigo enfoca, ainda, questões importantes relativas ao papel do uso do castelhano na criação, análise, interpretação e construção de blocos continentais, visando a uma perspectiva de um futuro melhor, voltado, sobretudo, para as gerações vindouras.

Com o uso de breve bibliografia e de métodos analíticos, descritivos e dedutivos, os estudos fixam alguns pontos e paradigmas necessários e realçou a contribuição dos processos educativos linguísticos para o bem estar e a civilidade das nações do entorno.

O tema básico não indica ou sugere opiniões exaurientes, senão vislumbra que o ensino, o domínio e a especialização do espanhol podem significar um hito decisivo em direção ao progresso global via ciências jurídicas, mesmo das pessoas que não o tem como língua nativa.

\section{ORIGEM DE LÍNGUAS JURÍDICAS NA HISPÂNIA DURANTE AS IDADES ANTIGA E MEDIEVAL}

Antes de fazer-se uma correlação e uma síntese historiográfica, que tendem a revelar a importância do uso da língua hispânica, no centro da análise e construção dos principais direitos que governam hoje a humanidade, faz-se mister depurar a capacidade comunicativa das relações antropológicas de povos que se formaram no passado e que tinham, por excelência, base e primado, fatores culturais que possibilitaram a múltipla inter-relação de pessoas que possuíam raízes e características originárias de regiões comuns.

Com efeito, ainda que se tenham presentes os marcos e os signos dos ciclos e os processos de vida gregária dos habitantes de algumas regiões, que levaram à criação de nações que falavam o castelhano, supõe-se que a língua, hoje, também, conhecida como espanhol, teve seu berço na cadeia dos Pirineus, situada entre a França e a Península 
Ibérica, embora há estudos que indiquem que sua fonte remonte ao final da Idade de Bronze, na cidade de Tarteso, onde se teria fundado a atual área de Andalucía.

De provável procedência africana, antes mesmo da migração de tribos para a região europeia que cruzaram a faixa do Mar Vermelho até à costa oceânica da Espanha e de Portugal, muitas línguas ali se misturavam desde a época de povoação dos fenícios e gregos (1.110 anos a.C) em Cádiz; chamada pelos romanos de Gades e, pelos árabes, de Qádis, que, na linguagem púnica, significava: "recinto de muralhas". Informes importantes também mostram que cidades como Málaga e Ibiza receberam a influência constante de outros povos belicosos, como os fóceos, os etruscos e os cartagineses.

Questões de disputas territoriais e comerciais levaram à conquista de ilhas do Mediterrâneo e à destruição de Tartesos, quando a Andaluzia foi anexada pelos bretões no ano 300 a.C., sendo retomada por Amílcar no ano 240 a.C., adido militar econômico que depois foi confrontado violentamente pelos romanos, mas não sem antes evidenciar a clara a vocação, também artística, herdada dos contatos ali feitos com outras diversas partes da atual França e Itália. Dessa forma sincrética, os vocábulos ali praticados se mesclavam em sufixos e faziam surgir novas cidades, em um panorama que continuou com as invasões bárbaras, dos celtas e dos cristãos que resolveram fixarse na Hispânia no século VII a.C., especialmente no centro e no Baixo Aragão. Em que pese a carência de uma unidade linguística, desta época é que muitos toponímicos da celtiberia se anotaram com elementos informativos oriundos sobretudo de palavras latinas face à chegada dos romanos que acabaram com as rivalidades locais, impondo seus valores culturais, que incluíam os conceitos e institutos estoicos sobre lei, cidadania e direito.

\section{DEFINIÇÃO SINÓPTICA DE DIREITOS HUMANOS E A CONTRIBUIÇÃO ESPANHOLA}

Como a Administração do Império Romano já era sistematizada e bastante avançada, impende assinalar que não só o modo de vida dos ibéricos mudou, como se criaram também novas cidades que acoplavam outros sentidos às línguas da região. Este feixe de alteração cultural total se deu no escopo das legislações ocidentais destinadas 
aos habitantes nativos e os estrangeiros, como na hipótese dos toponímicos vascos de Zaragoza.

Os idiomas e dialetos locais, energizados ainda pela língua grega e pelo florescimento da literatura latina, ao lado do irlandês, do gaulês, do escocês, do gótico, do alemão, do inglês, do holandês, do russo, do polaco, do tcheco, do búlgaro, do servocroata, do grego, do albanês e da maioria das línguas itálicas e escandinavas, podem ser considerados, assim, de origem indo-europeias; se bem que essas não exibam interseções com o etrusco, o lapão, o finlandês, o húngaro e o estoniano, que pertencem ao grupo das línguas índias e persas, complementando-se ainda com os judeus sefardíes.

Mesmo com o fim da dominação romana, o legado linguístico que ficou são os abundantes nomes vinculados à toponomia, porquanto os alicerces e valores daquela ora se entrecruzavam às culturas existentes. Parece certo que esta miríade de palavras serviu à definição sinóptica de "direitos futuros" e que a língua espanhola sofreu uma relevante contribuição, ao contatar e se retroalimentar com outros países. Nos contatos da maioria com a delicada precariedade das condições de saúde, higiene e segurança mínimas dos povos, cabe aqui também entender-se por "direitos futuros" os que visavam à realização de ideais humanísticos e à hipertrofia dos Estados que acabou desempenhando um papel fundamental de prover as possibilidades de vida, para os indivíduos e suas famílias.

Desta forma, o nascimento de uma "doutrina de proteção de direitos" contou, também, com a decisiva colaboração de escritores de língua espanhola, como Cervantes, em sua memorável obra Dom Quixote, até passar pelo dramaturgo “Don Juan" Tirso de Molina, às obras de Lope de Vega, que escreveu inúmeras peças de teatro e de comédia.

Nada obstante o cerramento religioso dos espanhóis, enquanto Estado-nação, com a exacerbação do catolicismo, notadamente após a consolidação de suas pretensões ultramarinas, com os movimentos das grandes navegações mercantilistas que pousou no solo americano, é indene de dúvidas que o prestígio da língua castelhana só não decaiu graças ao esforço do clero de converter os "gentios" ao substituir o latim e pela inegável força herdada das legislações absolutistas, autoritárias e despóticas dos governos que duraram na Idade Moderna até a sua perda de expressão política no panorama mundial. 


\section{OS SISTEMAS DE TUTELA DE DIREITOS LATINO-AMERICANOS E GLOBAIS EM CASTELHANO}

Na identificação do uso da língua espanhola e em um contexto global, como fruto do colonialismo ibérico, que marcou os séculos XVI a XIX, as tradicionais escolas latinoamericanas foram inauguradas a partir da "independência" de muitos países que obtiveram autonomia política e administrativa frente à metrópole após a insatisfação dos criollos e sob o comando de líderes locais, como San Martin e Bolívar. Nestes tempos, o castelhano foi o idioma eleito para consagrar a positivação científica de várias normas pioneiras contra os excessos do individualismo burguês industrial, apresentando-se, na hipótese, os antecedentes da Constituição do México, de 1917, que já manifestavam preocupação materiais com os "direitos sociais". Bom assinalar, ainda, a sua contingência junto com a Revolução Russa e a doutrina alemã da Constituição de Weimar, na feitura e na publicação do Tratado de Paz de Versalhes (1919), ratificado pela Liga das Nações em 1920, que pontificou que o trabalho é uma realidade humana singular que não pode ser equiparado à mercancia; ideia essa abraçada pela OIT. Neste sentido, aliás, a língua espanhola foi também o veículo de transcrição das aspirações laborais e coletivas que sedimentaram a "Declaración de Derechos de los Obreros del Pueblo Explotado de 1918". A escolha do idioma, outrossim, revestiu-se na Declaração Universal de Direitos do Homem e na criação das Nações Unidas, dentre outros marcos de proteção que exibem as mesmas características atinentes aos direitos essenciais, em especial os do trabalho, contemplados com os atributos de historicidade, inalienabilidade, imprescritibilidade e irrenunciabilidade. Sobre o tema, DUARTE ${ }^{1}$ :

"(...) desde los albores del Derecho Laboral se ha puesto como centro de
atención al ser humano que presta el servicio, por esa razón se ha dicho que
el contrato de trabajo es un contrato 'antrópico' (Gialdino). El diseño basado
en el Derecho protectorio ha creado técnicas jurídicas que intentan garantizar
un valor fundamental como es la dignidad humana, que es inherente a la
persona, no requiere del reconocimiento del legislador, así lo dice el
Preámbulo de la Declaración Universal, y es la causa de los derechos
humanos".

${ }^{1}$ REVISTA DE DERECHO LABORAL. Normas internacionales y Derecho interno: aplicación judicial de las normas internacionales de trabajo. Dirigido por Mario Eduardo Ackerman y Valentín Rubio. UubinzalCulzoni Editores. 1a. ed., Santa Fé, 2010, p. 173. Nestes estudos, os investigadores deixaram bem realçadas as análises das teses realistas sobre o antropocentrismo laboral. 
Em verdade, esses vetores diretivos, da doutrina e da ONU, foram decisivos para que países como a Argentina, com o pioneirismo de Juan Peron, consagrasse uma política ativa de tutela de pessoas e dos trabalhadores, seguidas, então, por comunidades latino-americanas que ecoou em vários países até chegar hoje à globalização econômica. Esta gama de fatos foi decisiva para a afirmação mundial de direitos, em castelhano.

$\mathrm{Na}$ avaliação da importância da língua espanhola, na criação, interpretação e execução de direitos construtivos, é forçosa e prévia a conclusão de que o "colonialismo de exploração" e a tardia independência dos países da América Latina atrasaram a ocorrência da plena industrialização e, por consequência, o progresso dessas nações, mas tendo em comum o uso quase uniforme de leis redigidas, ora em castelhano, ou em português, por força da divisão geopolítica das grandes potências da respectiva época.

É de se ver, assim, por curioso, que, a despeito da ruptura com a metrópole, os "novos pactos internos" e as medidas de governo não fizeram uso de línguas nativas, e sim do espanhol, mantido vivo e como idioma oficial dos países recém formados que se livraram do jugo da Espanha. Assim, no continente sul-americano, à exceção do Brasil e, depois, das Guianas Francesa, Inglesa e Holandesa, como protetorados de seus países europeus, as demais nações do cone conservaram o castelhano como língua-mãe.

Em que pese a imensa diversidade de etnias, raças e culturas existentes, toda a América Central (à exceção do Haiti) e o México, este situado na parte norte, falavam muitos dialetos autóctones, porém, na prática, para a conversação, acabou prevalecendo o idioma das classes e das burguesias dominantes locais. Tal dado é deveras interessante porque, malgrado a forte miscigenação genética, que houve na formação desses povos, além de uma carregada multiculturalidade, o castelhano foi eleito como a língua que tratava das questões nacionais, diplomáticas, estatais e que era, predominante, nos assuntos jurídicos.

Destarte, conquanto, após as grandes guerras, houvesse divisões ideológicas e um mundo político bipolarizado, com a hegemonia do planeta exercida pelos Estados Unidos e URSS, que falavam, respectivamente, inglês e o russo (nesse último caso, a maioria dos países da federação soviética tinham, também, dialetos, de origem eslava, e educação multilíngue). 
É pertinente anotar que as tensões e conflitos gerados pela guerra fria das duas grandes superpotências, sobretudo por causa dos choques entre o capitalismo e o socialismo, acarretaram um fluxo mundial migratório muito intenso, sobretudo dos povos antes colonizados para os mercados de consumo aparentemente promissores, em busca de ordem, segurança, saúde, trabalho, liberdade e prosperidade. Assim o foi o fenômeno da invasão hispânica no território norte-americano que, hoje, praticamente, tornou-se uma nação bilíngue, adotando o espanhol como uma "segunda língua", prestigiada, inclusive, junto aos órgãos da ONU, como a OIT e a OMS. Estes detalhes permitem asserir que o castelhano figura, portanto, como um elemento vital inserto nos sistemas de tutela de direitos globais e que sua permanência no cenário mundial parece que ainda vai durar por muitos séculos, pelo que há de se mencionar a relevância de seu uso até mesmo em todas as áreas científicas.

\section{DO USO DA LÍNGUA ESPANHOLA COMO REFERÊNCIA E NA CONSTRUÇÃO DE LEGISLAÇ̃̃ES}

Não obstante a difusão dos direitos jurídicos, nominados "humanos", alguns governos das nações de origem hispânica não conseguiram fugir do estilo populista, ou caudilhista, com administrações curvas às imposições externas. Escassearam-se, assim, muitos dos recursos econômicos e das oportunidades políticas desses Estados. Todavia, a unidade linguística dos seus povos conservou-se e serviu de paradigma nos princípios, normas e leis que regiam suas correspondentes populações, isto é, na formalização da ordem e proteção desses países, a língua castelhana exerceu mesmo uma função imprescindível.

Neste espectro, ao lado da maioria dos países da América, realce para o México, que foi pioneiro na "constitucionalização dos direitos", que ergueu e mantém, até hoje, um substantivo sistema de defesa e de tutelas jurídicas, individuais e coletivas, que se tornou viável e registrado devido aos registros do idioma. De modo análogo, as regras internas das atividades de inspeção, fiscalização e monitoramento de pessoas e bens das pátrias de solos americanos hispânicos encontram-se solidificadas em razão do uso da nova "língua-mater". 
Nestas nações, percebe-se, portanto, a existência de modelos, gestões, teses acadêmicas e projetos de responsabilidade que se fulcram em texturas, em que se "fala" e se "escreve" em espanhol, como produção linguística, ínsita de um "neocolonialismo", pois o projeto preliminar de alfabetização e desenvolvimento dos países hispânicos deuse mesmo debaixo da égide de uma educação, em parte, importada ou secundarizada.

Nesse passo, cumpre ver que a legislação e as Constituições autóctones hoje ainda se valem da língua castelhana para estruturar e reformar seu ordenamento jurídico como no caso das experiências portenhas que, em regra, são monofásicas, a exemplo do que se sucede com a atual Carta Magna de 1994 em vigor da Argentina e de todos os outros diplomas legais, que cuidam das mais variadas questões e matérias, tais como: a Lei de Inspeção de Cumprimento das Normas Trabalhistas (Lei no 18.962 e Lei Laboral no 765); a Lei de Riscos de Trabalho (Lei no 24.557 e Lei Laboral no 1.787), a Lei de Higiene e Segurança do Trabalho (Lei no 19.587 e Lei Laboral no 780); a Lei do Regime Sindical (Lei no 23.551) e a Lei da Negociação Coletiva (Lei no 23.545). Como se denota, a grande quantidade de aparatos e standards legais foram levados a cabo pelo uso imperativo da língua castelhana. De modo igual, nos modelos dos países latinoamericanos restantes, sem embargo da diversidade de povos e etnias, que se expressam em dialetos, próprios ou distintos, os regimes jurídicos destas nações não permitiram a adoção de outro idioma que não o hispânico, representativo das civilidades.

Esse é o caso do México que, equipando-se com uma conservadora tutela e, embora assolado por sucessivas crises políticas e econômicas internas longas, organiza a proteção aos direitos dos seus obreiros no art. 123 de sua Constituição, insculpida no idioma espanhol. A existência de outros povos, que habitaram ou ainda residem naquele país, não conseguiu destronar o castelhano, que se federalizou, e, a exemplo de outros Estados, reclamou-se seu uso ainda na tradução de tratados e convenções internacionais, sem que isto signifique o reconhecimento ou o status de supremacia de nenhuma língua.

Fato que, ao estudar-se a Lei dos Trabalhadores a Serviço do Estado (1967) e a Lei Federal do Trabalho (1970) mexicanas, ali estão resumidos todos os aspectos substanciais e processuais das matérias alusivas à saúde e à segurança laboral, com as previsões de treinamentos profissionais e, ainda, de esquemas de benefícios oferecidos. A Comissão Nacional de Saúde e Segurança Laboral e a sua relação com os comitês de 
higiene e saúde das empresas instaladas exige, ainda, a representação paritária de empregados e empregadores. Também se formulam queixas, celebram conciliações e atuam em disputas judiciais.

Assim, em todas suas tarefas, investigações e medidas, as ações governamentais e privadas são firmadas no idioma nacional, que é o castelhano, que possui peso jurídico ${ }^{1}$.

Nos demais países da América Latina, em que o espanhol pouco se distingue a não ser por sotaques, ou expressões genuínas populares, apesar de uma certa variação, as regras gramaticais são homogêneas, e, no terreno do Direito, aplicáveis às políticas, preventivas ou repressivas, de proteção geral das pessoas e entidades. Daí não se pode deixar de declinar que as mensagens sobre sindicalização, organização das profissões, regulamentação de direitos trabalhistas e, ainda, as disposições sobre saúde, segurança, medicina, acidentes, seguro, previdência e assistência social, foram feitas em espanhol, dentre outras normativas.

A atenção a esses aspectos se torna ainda mais útil quando se examinam os tipos modernos de tutela ambiental, uma vez que os modelos de proteção concebidos, priorizando as questões físicas, foram propostos e traduzidos para o espanhol, a partir de orientações e resoluções intergovernamentais e postulados públicos internacionais. Os discursos, orais ou escritos, proferidos em um idioma, que é falado e compreendido por quase meio bilhão de pessoas na atualidade, é, neste eixo, necessário para a redução de custos internos e externos. Pelo menos, nas opções até então assinaladas, a falta de domínio da língua hispânica importa, portanto, retrocessos e perdas futuras certas, na medida que o aumento da produtividade e para um bom aproveitamento no mundo empresarial e dos negócios a língua é estratégica.

\section{RELEVÂNCIA DO CASTELHANO COMO FONTE DE PROGRESSO E DE EDUCAÇ̃̃OO MUNDIAL}

Enquanto o quadro de muitas nações é de desemprego, de precarização dos postos de trabalho, ou mesmo da flexibilização desigual dos direitos dos trabalhadores

\footnotetext{
${ }^{1}$ FILAS, Rodolfo Capón Filas. Índice del Tratado de Derecho del Trabajo. Agosto 2014. Directiva Europea $94 / 45,22.09 .1994$. Nesta investigação, o autor buscou aperfeiçoar os métodos de prevenção de acidentes e doenças laborais.
} 
e a absorção da mão de obra possui índices elevados só nos países já desenvolvidos, como os EUA, o que faz pressupor que o modelo capitalista tem encontrado saídas para a vida laboral e, também, que está atento à relevância da participação de imigrantes, com taxas de empregabilidade que atingem níveis altos, a despeito do quadro catastrófico gerado pela pandemia do covid-19. A China, também, exibe alarmantes índices de crescimento econômico no trágico ano de 2020.

Este cenário contrasta, contudo, a realidade de muitas nações da União Europeia, que têm coeficientes de desempenho econômico bons, mas não extensivos aos países dos continentes americanos, onde não são aplicadas as políticas de remuneração justas. Aqui o uso constante do espanhol, nas relações pessoais e acadêmicas, critica a vulnerabilidade do mais fraco, em questões financeiras ${ }^{3}$. É o reconhecimento dos standards de direitos humanos ${ }_{L}$ outorgados diante de novas tecnologias, e, assim, o idioma constitui um imenso contingente de força laboral, que empurra as perspectivas dos imigrantes hispânicos, que enfrentam, pois, inúmeras discriminações e ameaças de deportação. De todo modo, ao aterrissar no solo dos países mais desenvolvidos, exige-se que os governos locais entendam a cultura e tenham, pelo menos, um certo domínio da língua daqueles estrangeiros para impor-lhes suas normas.

Se é verdade que as abstrações e as realidades sobre os direitos comparados, como as disciplinas, mudanças e classificações trabalhistas, são paradigmáticas e se sobrepõem às legislações estáticas ${ }^{1}$, de nada adianta exprimir, ou suprimir, por outro lado, seus conceitos evolutivos, sem que se compreendam antes o estilo de vida e a língua de visitantes e/ou imigrantes que vêm para somar ao progresso das economias dos países hegemônicos².

Nessas circunstâncias, esses Estados "receptores" de turistas e alienígenas, de procedência hispânica, precisam de meios institucionais e pedagógicos para adaptar-se às necessidades nativas ou regionais e, neste complexo tabuleiro geopolítico, planejar e promover tutelas básicas, convencionais, transitórias ou não, onde seja estratégico o controle educacional desta massa de emergentes, a familiarização com as novas línguas

1 CANIZARES, Felipe de Sola. Iniciación al derecho comparado. Barcelona: Consejo Superior de Investigaciones Científicas: Instituto de Derecho Comparado: 1954, p. 104.

2 LINARES, Francisco W. Esquema del derecho del trabajo de la seguridad social en Chile. Santiago: 1965, p. 11. 
importadas são, assim, além de parâmetros civilizatórios, premissas de acesso à defesa de direitos, em que o "idioma-natal" atende à estabilização e à sustentabilidade interna. Neste caso, o valor do espanhol é um diferencial, inclusive, ao fluxo da prosperidade desejada e acenada.

Pari passu, como fonte de desenvolvimento e na educação mundial, além de se comprovar a extensa e variada faixa geográfica, onde hoje se fala o castelhano, bom estatuir seu auxílio na formatação de dispositivos, que compõem países adiantados, ou não, em temas como seguro, sindicalismo e funcionamento de órgãos estatais no mundo com o propósito de mentalizar e contribuir para os novos parâmetros no Direito global.

Nesta ordem de ideias, a Espanha tem sido uma das pioneiras na vanguarda de tutelas individuais e vem introduzindo políticas públicas que editam leis orgânicas de saúde, diretrizes de oferta de empregos e bases educativas, cujo escopo também propõe o uso de programas ambientais que contemplam a capacitação de trabalhadores, com a exclamação de uma rede legislativa, de certa forma, bem mais humanista ${ }^{5}$. Seu destaque advém ainda da adoção de órgãos de inspeção laboral, de funções disciplinares, a quem se lhes reservam atividades de mediação através de meios autocompositivos, que, além de tudo, ainda se prestam a ações cooperativas (Lei 31, de 1995; e Decreto Real 665/97). A profusão de preceitos novos e destas marchas jurídicas impulsionam posturas cidadãs, o que acaba influenciando vários outros países, que, em suas decisões públicas e privadas, escoram-se, portanto, em "tutelas existenciais", redigidas primeiro no idioma castelhano.

Atenta ainda às provisões e às Diretivas da União Europeia sobre o trabalho ( $E C$ Framework Directives, de 1989), a Espanha se notabilizou também como país que usa seu idioma principal para divulgar marcos sucessivos sobre inúmeros temas, dentre eles segurança, proteção, emprego, saúde e prevenção de acidentes laborais, além de perfilar posições muito avançadas, no que concerne aos ambientalismos e à ecologia, a despeito de reportarem à necessidade de resolução dos problemas dos "direitos passados e futuros", no orbe planetário sem antever as nefastas implicações provocadas pela miséria e o desemprego.

Verbere-se que, ainda assim, salta aos olhos a relevância do castelhano como fonte de consulta para o impulso do progresso e na educação mundial, em vista de sua 
situação absolutamente vital nos países imbricados com os setores das economias, dos governos e mercados, em todas as espécies de assuntos físicos, sociais ou ambientais.

A feitura de legislações, que abarquem este amplo leque de conhecimentos, para a construção de "direitos futuros", tal como germinado pela doutrina anglo-saxã ${ }^{1}$, neste mesmo vértice, tem encontrado no espanhol um idioma que vem sendo capaz de, em um plano universal, promover ainda o crescimento através dos ideários da educação, sendo uma natural consequência que esta venha a reboque das ciências jurídicas e que se comuniquem.

\section{PERSPECTIVAS DE INTERNACIONALIZAÇÃO DO BEM-ESTAR E O BILINGUISMO ESPANHOL}

Fatores físico-naturais, culturais e tecnológicos vêm alterando o equilíbrio da biota, sendo que, essas mudanças socioeconômicas, experimentadas, até aqui, em parte, por força da ideologia capitalista, demandam um núcleo de comunicação pessoal que interfere já, diretamente, nas relações, condições e qualidades de vida neste século.

Sem dúvida, as questões apanhadas nos itens anteriores rechaçam haver hoje um bem-estar mundial, com o status de patrimônio supranacional e, neste prumo, as disciplinas técnico-científicas se incrementam, porém o ensino e a aprendizagem bilíngue ainda não se concretizaram como prioridade na grade escolar dos países latinos e pobres.

$\mathrm{Na}$ verdade, as discussões de questões geopolíticas se travam hoje mais com o uso do idioma inglês; contudo, na esteira do que se ressaltou, o idioma castelhano vem ganhando, cada vez mais espaço, quantitativo e qualitativo, no esquema externo, já que se faz presente de maneira significativa e vem sendo usado para legitimar a atuação de órgãos multilaterais e ultraterritoriais. São diálogos diários, globais, regionais e locais, sobre direitos comunitários ou transnacionais, o que configura um só cinturão cultural, que conta com a participação efetiva de termos e linguagens do idioma espanhol. Neste ponto, exsurge um forte apelo científico, político e acadêmico para que os debates sobre

\footnotetext{
${ }^{1}$ SIMITIS, Spiros. Juridification of labor law. In: TEUBNER, Gunther (Ed.). Juridification of social spheres: a comparative analysys $i$ the aras of labor, corporate, antitruste and social welfare law. Berlin: Walter de Gruyter, 1987, p. 124. Já a legislação alemã, que acabou influenciando a espanhola sobretudo no tocante ao direito de greve e também nas formas de autocomposição dos conflitos, dá mais realce para a mediação e a conciliação processuais.
} 
problemas e sobre "direitos humanos" sejam dissecados também na viva língua castelhana, dada à sua larga amplitude, já que é falada e compreendida na maioria dos países da América Latina. Também, no campo da mídia, o espanhol, por sua vez, denuncia os medulares conflitos associados ao desemprego, aos episódios de violência urbana e a alguns ensaios de práticas terroristas. Com estes dados, usa-se, ainda, o castelhano para divulgação das condições de vida dos povos que habitam nestas regiões, oferecem-se produtos e serviços de consumo mundial e as soluções que prospectam o desejo de progresso são versadas nesta língua. No mais, convenções, tratados, seminários, cursos, simpósios, palestras, assuntos sociais têm sido produzidos ou traduzidos, também, no idioma espanhol, de sorte que os caminhos para a globalização equitativa, que equivale a uma resposta real das preocupações do mundo, ante as graves crises financeiras internacionais e nacionais, requerem o conhecimento, o ensino e os métodos de aprendizagem desse fundamental instrumento dialógico. Vencer as cruciais e complexas questões, que emergem dos desafios atuais, não prescinde, pois, da língua neolatina, que maternaliza a arte e os direitos futuros. Logo, a perspectiva da internacionalização desse bem-estar passa pelo bilinguismo espanhol.

\section{A INFLUÊNCIA JURÍDICA DO CASTELHANO NOS BLOCOS DO MERCOSUL E DA UNASUL}

Impõe-se como estratégia corrente na criação de direitos e também na diplomacia global e, não obstante a envergadura e da importância de órgãos multilaterais, como a ONU, não se delinearam resoluções objetivas que o mundo espera neste século XXI, em particular, para garantir a sobrevivência da população do planeta nessa pós pandemia.

Em agravamento à situação de colapso ambiental, a ECO-92 e outros tratados multilaterais seduziram as nações não desenvolvidas a assinarem compromissos formais, de redução de seus potenciais econômicos, para não poluírem a atmosfera, com a emissão de gases prejudiciais à camada de ozônio. Daí que os países, subdesenvolvidos e emergentes, concordaram com políticas ambientais restritivas, mas ninguém cuidou de resolver seus problemáticas de desenvolvimento antrópico. Sem crédito, capital e estrutura, é praticamente impossível instalar o uso de energias 
renováveis como prioridade em países pobres, de modo que é ilusão falar ou potencializar um crescimento econômico sustentável global, já que o progresso de povos e de nações depende do vigor industrial dos seus processos produtivos.

Logo, há populações frágeis no globo que permanecem destituídas de perspectivas de reais melhorias. De outra parte, e na esteira do engodo da sustentabilidade, houve calote das prometidas compensações de carbono dos países ricos frente aos países usuários dos mecanismos antipoluentes. O comércio das emissões das cotas das Unidades Equivalentes Atribuídas (Assigned Amount Units AAUs) não prosperou no sistema prometido, pois Estados Unidos e outras potências, na prática, boicotam o Protocolo de Kyoto. Nesta mesma trilha das COPs, os atuais (e antigos) presidentes dos Estados-líderes se declararam, explicitamente, a favor dos ecologismos verdes, mas não solvem as sucessivas crises econômicas. Estes fatos denunciam o fracasso da atual política ambiental. Graças à subserviência das leis dos países não contaminantes na ordem mundial, as óbvias dificuldades de superar os problemas e as resistências jurídico-culturais à mudança são que põem às cartas na mesa dos negócios sociais.

Os países exportadores de matérias-primas e que sobrevivem de commodities são, em maioria, nações castelhanas, que precisam, por conseguinte, de saídas empíricas, para capitanear um amplo programa de oportunidades mútuas. Nesse compasso, a difusão do espanhol é crucial à evolução, cooperação e ao logro de interesses de países que podem encontrar, também, na sua língua, uma "ponte", ou um "biombo", para atravessar essas "ondas imperiais", proporcionando a integração de blocos estatais, desde que não tenham as mesmas vontades unidirecionais hegemônicas do atual concerto mundial. De outro giro, a preocupação matriz para o sucesso do antropocentrismo latino-americano começa pela institucionalização de uma educação de direitos essenciais ultramarinos, sobretudo na região.

Com as propostas de um Direito supranacional, orquestrado pela ONU, OIT e OMS, já malogradas e limitadas, para realizar uma revolução humanitária, de "justiça social", a acomodação dos interesses, primários e gerais, dos povos e das nações, sob uma regência cosmopolita, pode, e deve, partir de referenciais linguísticos e de instrumentos jurídicos não retóricos, que avaliem, critiquem, criem e efetivem direitos mais dignos, nas soluções das adversidades das comunidades menos favorecidas. Neste 
ínterim, rejeitar os retrocessos sob o eixo de uma visão idealista, os limites linguísticos e geográficos é estimulo à formação de blocos continentais, que ofereçam chances de progresso e de crescimento humanos.

Os intercâmbios das relações jurídicas, todavia, passam pelos diálogos nas línguas estatais envolvidas e pela consignação do ensino básico das mesmas nos curriculum desses países. Com a obrigatoriedade de um marco bilíngue comum e a existência de acordos sobre os processos de paz e as garantias de segurança e mantença mínima desses povos, estas nações poderiam unir-se e fortalecerem-se mais, e a linguagem do espanhol é um facilitador.

Para a concessão, a legitimidade e o exercício de direitos e deveres comuns, que seriam acertados, segundo as necessidades ou as circunstâncias específicas de cada povo ou nação partícipe, nesse protótipo jurídico algumas distorções jurídico-históricas, que cominam angustias, lesões e infortúnios a esses povos, podiam ser corrigidas, ou, ao menos, atenuadas.

Neste preceito, a língua espanhola é fulcral para a atuação política de entes que são ainda forças tímidas, tais como o CARICOM (Comunidade do Caribe), o CACM (o Pacto Andino da América Central); o MERCOSUL (Mercado Comum do Sul) e a UNASUL (União Sul-americana); células supraestatais e intergovernamentais, consórcio dos Estados da América, mas que não respondem aos ideários da integração latinoamericana. Multissetorial, tal como a CAN (Comunidade Andina de Nações), a UNASUL e o MERCOSUL já atendem hoje a uma população de mais de 400 milhões de habitantes, que usam o espanhol como língua oficial, embora o Brasil, que detém quase metade desta população e território, fale o português. Para a integração e a cooperação político-econômica tornar-se uma unidade multiterritorial intercambiável, que possa cumprir os interesses prementes dos países do sul, a similaridade dessas línguas afins poderia precipitar a criação de uma "Constituição Comunitária", para harmonizar o pluralismo jurídico-cultural desses Estados e de suas ações externas.

\section{CONSIDERACÕES FINAIS}

Neste breve estudo, focou-se a importância do castelhano na criação e consecução dos "direitos passados e futuros". O artigo partiu das particularidades históricas e culturais dos eventos, marcou os povos e os Estados, que ocuparam os 
territórios de origem hispânica, e avaliou-se o impacto e contribuição da língua na produção dos sistemas de tutela, no campo político-jurídico. Sob a perspectiva de evolução da América Latina, em princípio, e para, em seguida, proceder a um exame evolutivo global, nas questões econômicas e sociais, é de se ver o processo de uso da língua espanhola, como referência na construção legislativa de países que ganhou força com as tradicionais obras do capitalismo renascentista, desde os romanos aos geniais escritos de Miguel Cervantes e de Lope de Vega, passando por fontes da literatura eclesiástica, do catolicismo nas colônias do Reino Espanhol, até a formação de novos países independentes no continente americano. A partir daí, o idioma recebeu impulsos e afirmação, foi usado como língua oficial nos países autônomos recém criados, atingindo seu apogeu com a Constituição Mexicana de 1917, de forte índole trabalhista e libertária, que, depois, seria recopiada na Argentina e no Brasil, após influenciar a Declaração Universal de Direitos do Homem das Nações Unidas, no conturbado período pós-guerra, que repercute até hoje.

A verdade é que, nas relações entre Estados, nos documentos epistolares e nos intercâmbios interpessoais, cada vez mais se aproveita o idioma castelhano, de modo que ele pode ser considerado um elemento essencial ao progresso global. Já sob o ângulo jurídico, a língua espanhola possui uma penetração forte, inegável em toda a América Latina, tendo substituído, praticamente, os dialetos nativos, para tornar-se a “língua-mãe", usada por quase meio bilhão de pessoas hodiernamente, estando, hoje, ínsito na educação tradicional.

Neste sentido, o ensino e a aprendizagem bilíngue do espanhol constituem-se ainda "fluidos" certos para auxiliar à mundialização do bem-estar, sobretudo pelo seu poder de ativa integração na formação de tratados, convenções e de blocos supranacionais, tais como o MERCOSUL e a UNASUL; unidades político-territoriais, usuárias do tronco da língua luso-hispânica, que podem e devem afiançar alianças sólidas e urgentes, ao terem como objetivo a impulsão de governos para o desenvolvimento dos países e dos povos dessa região.

Presente, ainda, na CARICOM, no CACM e na CAN, o idioma espanhol, por extensão, é realçado ainda nos países desenvolvidos, que recebem imigrantes, e que, sob esta égide, precisam também entender a língua, para patrocinar e dominar os 
interesses, direitos e deveres escritos na ordem latino-americana, como parte dos efeitos globais.

Do exposto, o ensino, a aprendizagem do castelhano e o bilinguismo urgem, e, por isso, realça-se que a criação, análise, interpretação e construção de um direito, melhor e mais justo, em áreas continentais, depende de gerações futuras mais coesas, preparadas e habilitadas, para edificarem um projeto de felicidade jurídica supranacional e global.

\section{AGRADECIMENTOS}

Aos professores da UBA - Universidade de Buenos Aires, em especial, aos Dr. Ricardo Rabinovich, líder da Revolução Jurídico-humanista Idealista da América Latina.

\section{REFERÊNCIAS}

CANIZARES, Felipe de Sola. Iniciación al derecho comparado. Barcelona: Consejo Superior de Investigaciones Científicas: Instituto de Derecho Comparado: 1954.

FILAS, Rodolfo Capón Filas. Índice del Tratado de Derecho del Trabajo. Agosto 2014. Directiva Europea 94/45, 22.09.1994.

LINARES, Francisco W. Esquema del derecho del trabajo de la seguridad social en Chile. Santiago: 1965.

REVISTA DE DERECHO LABORAL. Normas internacionales y Derecho interno: aplication judicial de las normas internacionales de trabajo. Dirigido por Mario Eduardo Ackerman y Valentín Rubio. Uubinzal-Culzoni Editores. 1a.. ed., Santa Fé, 2010.

SIMITIS, Spiros. Juridification of labor law. In: TEUBNER, Gunther (Ed.). Juridification of social spheres: a comparative analysys i the aras of labor, corporate, antitruste and social welfare law. Berlin: Walter de Gruyter, 1987. 


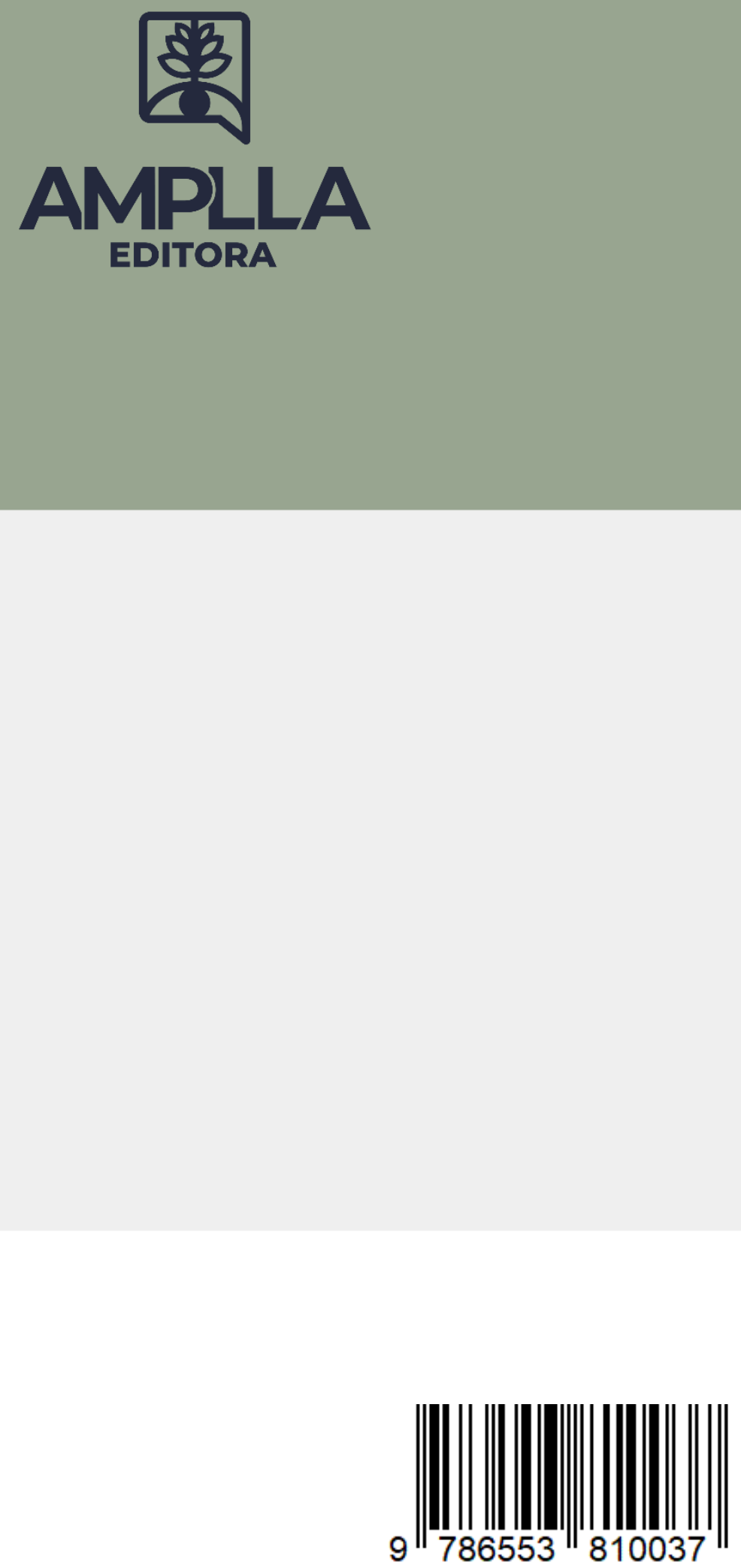